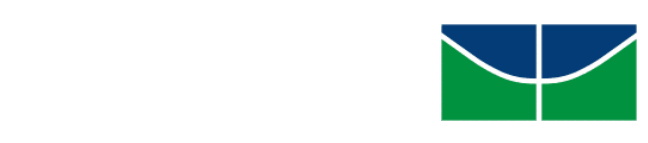

UNIVERSIDADE DE BRASÍLIA

FACULDADE DE EDUCAÇÃO

PROGRAMA DE PÓS-GRADUAÇÃO EM EDUCAÇÃO

DISSERTAÇÃO DE MESTRADO

FORMAÇÃO CONTINUADA DE PROFESSORES ALFABETIZADORES NO

PACTO NACIONAL PELA ALFABETIZAÇÃO NA IDADE CERTA

VIVIANE CARRIJO VOLNEI PEREIRA

Brasília - DF

2016 


\title{
FORMAÇÃO CONTINUADA DE PROFESSORES ALFABETIZADORES NO PACTO NACIONAL PELA ALFABETIZAÇÃO NA IDADE CERTA
}

\begin{abstract}
Dissertação apresentada ao Programa de PósGraduação da Faculdade de Educação da Universidade de Brasília - UnB, como requisito parcial para obtenção do título de Mestre em Educação na linha de Pesquisa em Profissão Docente, Currículo e Avaliação PDCA; sob orientação da $\operatorname{Prof}^{a} \operatorname{Dr}^{a}$ Kátia Augusta Curado Pinheiro Cordeiro da Silva.
\end{abstract}


FICHA CATALOGRÁFICA ELABORADA AUTOMATICAMENTE, COM OS DADOS FORNECIDOS PELO (A) AUTOR (A)

CP436f

CARRIJO VOLNEI PEREIRA, VIVIANE.

FORMAÇÃO CONTINUADA DE PROFESSORES ALFABETIZADORES NO PACTO NACIONAL PELA ALFABETIZAÇÃO NA IDADE CERTA / VIVIANE CARRIJO VOLNEI PEREIRA;

orientador KÁTIA AUGUSTA CURADO PINHEIRO CORDEIRO DA SILVA. -- Brasília, 2016.

$181 \mathrm{P}$.

Dissertação (Mestrado - Mestrado em Educação) -- Universidade de Brasília, 2016.

1. FORMAÇÃO CONTINUADA DOCENTE. 2. FORMAÇÃO CONTINUADA DE PROFESSORES ALFABETIZADORES. 3. PNAIC. 4. PRÁXIS DOCENTE. I. AUGUSTA CURADO PINHEIRO CORDEIRO DA SILVA, KÁTIA, Orient. II. Título. 


\section{FORMAÇÃO CONTINUADA DE PROFESSORES ALFABETIZADORES NO PACTO NACIONAL PELA ALFABETIZAÇÃO NA IDADE CERTA}

\section{DEFESA DE DISSERTAÇÃO DE MESTRADO APRESENTADA À SEGUINTE BANCA EXAMINADORA}

Brasília, 09 de dezembro de 2016. 


\section{AGRADECIMENTOS}

Senhor, obrigada por andares comigo por toda a minha vida, orientando-me na minha caminhada e aguardando por mim do outro lado da estrada. Nada seria concretizado se não sentisse a sua luz e presença na minha existência.

Pesquisar em nosso tempo significa participar historicamente, formando e sendo responsável por revelar os contextos e as contradições que se constituem ao longo do processo de estudo e reflexão. Esta pesquisa resulta do esforço e criação daqueles que pensaram a educação, dos que pensam a educação e, sobretudo, dos que, a cada dia, procuram criar a educação como processo de emancipação humana em nossa sociedade.

Agradeço ao meu esposo e meus filhos, à minha família e amigos que tiveram paciência durante os períodos de minha ausência e me apoiaram para que eu cumprisse essa etapa da vida.

Aos meus colegas de Mestrado e do Grupo de Estudos e Pesquisas sobre a formação e atuação de Pedagogos e Professores - GEPFAPe, que muito me ajudaram nesse processo de constituição profissional.

A Secretaria de Estado de Educação do Distrito Federal por possibilitar o afastamento remunerado para estudos, permitindo o aprofundamento dos meus estudos e o êxito da pesquisa realizada.

A Prof ${ }^{a}$ Dr $^{a}$ Shirleide Pereira da Silva Cruz que além de grande amiga, também sempre foi parceira durante a pesquisa.

A Prof $^{a}$ Dr $^{a}$ Edlamar Oliveira dos Santos que muito colaborou para a elaboração desta pesquisa com sua participação na Banca de Qualificação e também de Defesa, além de ser um importante referencial teórico para nosso estudo.

E em especial, a $\operatorname{Prof}^{a} \operatorname{Dr}^{\mathrm{a}}$ Kátia Augusta Curado Pinheiro Cordeiro da Silva, minha eterna Orientadora, que muito me ensinou sobre o verdadeiro sentido de “ser professor" e o valor da profissão docente. Muito obrigada! 
"Educar não é a mera transferência de conhecimentos, mas sim conscientização e testemunho de vida. $E$ construir, libertar o ser humano das cadeias do determinismo neoliberal, reconhecendo que a história é um campo aberto de possibilidades. Esse é o sentido de falar de uma educação para além do capital: educar para além do capital implica pensar uma sociedade para além do capital". 


\section{RESUMO}

A pesquisa analisou as concepções que norteiam a formação continuada desenvolvida no âmbito do Pacto Nacional pela Alfabetização na Idade Certa (Pnaic). O Pacto Nacional pela Alfabetização na Idade Certa (Pnaic) foi implantado desde 2013 junto às escolas públicas com o objetivo principal de garantir o direito à alfabetização plena a todas as crianças até oito anos de idade, ao final do $3^{\circ}$ ano do Ensino Fundamental. A formação continuada, um dos eixos do Pnaic é, conforme a Portaria $n^{\circ} 867$ de 04 de julho de 2012, presencial para todos os Professores Alfabetizadores do $1^{\circ}, 2^{\circ}$ e $3^{\circ}$ anos, e também das classes multietapas e multisseriadas, e se dá em parceria com a Rede de Universidades Públicas que atuam em parceria com o MEC, na formação continuada de professores alfabetizadores pelo Pró-Letramento. Nesse sentido, com embasamento teórico de Curado Silva (2011), Curado Silva e Limonta (2014), Gadotti (2010), Vásquez (1997); investigamos quais concepções estão subjacentes a essa formação continuada, e isto, porque tomamos a pespectiva crítico-emancipadora como elemento articulador entre teoria e prática, pois nela reside a possibilidade de perceber o movimento dialético da realidade, podendo ser esta melhor compreendida. Para tanto, a presente pesquisa realizou um estudo de fundamentação histórico-social das relações e interações das esferas sociais e políticas referentes à formação de professores alfabetizadores, considerando Dourado (2009), Freitas (2003), Gontijo (2014), Mortatti (2003, 2011), Oliveira (2011); e uma análise documental da Formação Continuada no Pnaic, a partir das contribuições de Cruz e Ferreira (2010), Dalben e Gomes (2009), Oliveira (2012), Santos (2011, 2014). Nesse sentido, tendo como abordagem metodológica o materialismo histórico e dialético - Marx (1978, 1982, 2008), Marx e Engels (2007) - realizamos essa análise documental considerando as categorias que emergem de nosso objeto: (i) Mudança de identidade profissional docente, ii) Relação teoria e prática, iii) Professor reflexivo, iv) "Multiprofissional", v) Responsabilização do professor e qualidade da educação, vi) Formação na perspectiva do Multiplicador, vii) Formação e valorização docente, viii) Perfil alfabetizador, ix) Alfabetização cultural; compreendendo assim, as concepções que legitimam e sustentam essa formação docente.

Palavras-chave: formação de professores; formação continuada; práxis docente; Pnaic. 


\begin{abstract}
The research analyzed the conceptions that guide the continued formation developed within the scope of the National Pact for Literacy in the Right Age (PNAIC). The National Pact for Literacy in the Right Age (PNAIC) has been implemented since 2013 in public schools with the main objective of guaranteeing the right to full literacy for all children up to the age of eight, at the end of the 3rd year of elementary school. Continuing education, one of the axes of the Pnaic is, according to Administrative Rule no. 867 of July 4, 2012, present for all teachers Literacy teachers of the 1st, 2nd and 3rd years, as well as the multi-stage and multiWith the Network of Public Universities that work in partnership with the MEC, in the continuing formation of literacy teachers by Pró-Letramento. In this sense, based on Curado Silva (2011), Curado Silva and Limonta (2014), Gadotti (2010), Vásquez (1997); We investigate which conceptions underlie this continuous formation, and this, because we take the critical-emancipatory perspective as an articulating element between theory and practice, because in it resides the possibility of perceiving the dialectical movement of reality, and can be better understood. In order to do so, the present research carried out a study of historicalsocial foundation of the relations and interactions of the social and political spheres related to the formation of literacy teachers, considering Mortenti (2003), Freitas (2003), Gontijo (2014) 2011), Oliveira (2011); And a documentary analysis of Continuing Education in the PNAIC, based on the contributions of Cruz and Ferreira (2010), Dalben and Gomes (2009), Oliveira (2012), Santos $(2011,2014)$. In this sense, taking as a methodological approach historical and dialectical materialism - Marx (1978, 1982, 2008), Marx and Engels (2007) - we carry out this documentary analysis considering the categories that emerge from our object: (i) , (Ii) Teaching skills, (iii) Teaching skills, (iv) "Multiprofessional", (v) Teachers' responsibility and quality of education, ) Cultural literacy; Thus understanding the conceptions that legitimize and sustain this teaching formation.
\end{abstract}

Keywords: teacher training; continuing education; teaching practice; Pnaic. 


\section{LISTA DE SIGLAS E ABREVIAÇÕES UTILIZADAS}

ANA - Avaliação Nacional de Alfabetização

Anfope - Associação Nacional pela Formação dos Professores

ANPAE - Associação Nacional de Política e Administração da Educação

ANPED - Associação Nacional de Pós-Graduação e Pesquisa em Educação

CONBAlf - Congresso Brasileiro de Alfabetização

ENDIPE - Encontro Nacional de Didática e Práticas de Ensino

FE - Faculdade de Educação

IBICT - Instituto Brasileiro de Informação em Ciência e Tecnologia

IES - Instituição de Ensino Superior

INEP - Instituto Nacional de Estudos e Pesquisas Educacionais Anísio Teixeira

MEC - Ministério da Educação

OCDE - Organização para Cooperação e Desenvolvimento Econômico

ONU - Organização das Nações Unidas

PDCA - Profissão Docente, Currículo e Avaliação

PDE - Plano de Desenvolvimento da Educação

Pnaic - Pacto Nacional pela Alfabetização na Idade Certa

PNBE - Programa Nacional Biblioteca da Escola

PNE - Plano Nacional de Educação

PNLD - Programa Nacional do Livro didático

PPGE - Programa de Pós-Graduação em Educação

RNFC - Rede Nacional de Formação Continuada de Professores de Educação Básica

SAEB - Sistema de Avaliação da Educação Básica

SCIELO - Scientific Electronic Library Online (CNPQ)

SEEDF - Secretaria de Estado de Educação do Distrito Federal

UFPE - Universidade Federal de Pernambuco

UFPR - Universidade Federal do Paraná

UnB - Universidade de Brasília

UNESCO - Organização Educacional Científica e Cultural das Nações Unidas 


\section{LISTA DE QUADROS}

Quadro 1 - Percurso metodológico da pesquisa ..................................................... 30

Quadro 2 - Bases de pesquisa - Estado do Conhecimento ........................................ 36

Quadro 3 - Categorias - Estado do Conhecimento ................................................. 41

Quadro 4 - Metodologia - Estado do Conhecimento .................................................47

Quadro 5 - Temáticas de estudo e autores referenciados ..........................................104

Quadro 6 - Eixos de análise, pré-indicadores e indicadores ......................................123

Quadro 7 - Eixos de análise, indicadores e categorias do objeto ................................135

Quadro 8 - Referências autorais e teóricas - Pnaic ...................................................139 


\begin{abstract}
ANEXOS

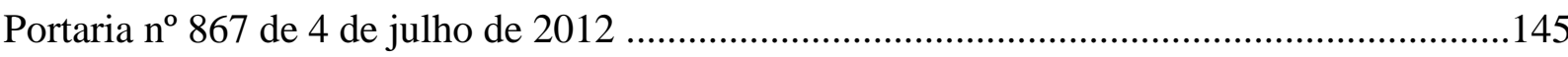

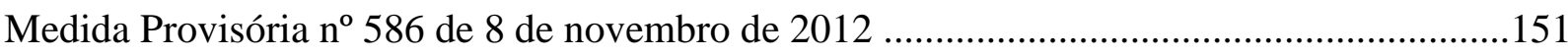

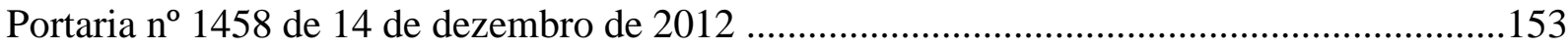

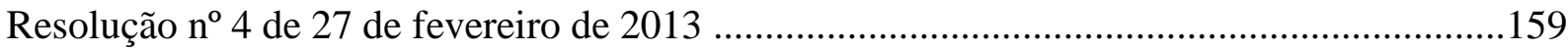

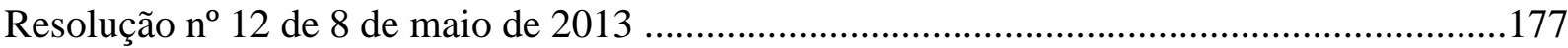


INTRODUÇÃO ...........................................................................................................11

CAPÍTULO 1 - CONSTRUINDO O OBJETO DE PESQUISA ……………........................15

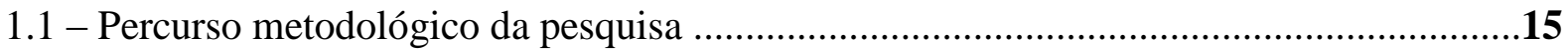

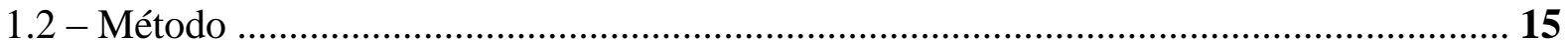

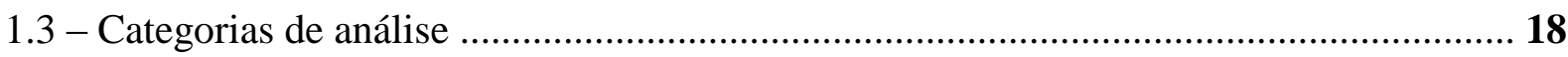

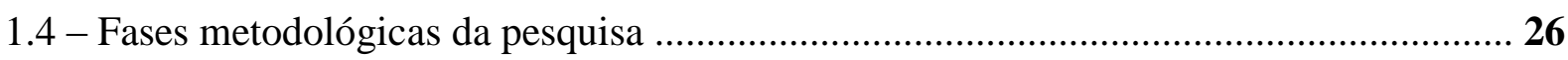

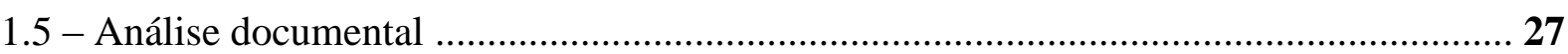

CAPÍTULO 2 - ESTADO DO CONHECIMENTO: OUTROS OLHARES SOBRE O

Pnaic ....................................................................................................................................................... 35

CAPÍTUlO 3 - POLÍTICAS PÚBLICAS DE FORMAÇÃo CONTINUAdA DE PROFESSORES ALFABETIZADORES E O PACTO NACIONAL PELA ALFABETIXAÇÃO NA IDADE CERTA 49

CAPÍtUlO 4 - O PACTO NACIONAL PELA ALFABETIZAÇÃo NA IDADE CERTA: ANALISANDO AS CONCEPÇÕES DE FORMAÇÃO CONTINUADA .......66

4.1 - Eixo: Papel/Função da formação continuada ..................................................................69

4.2 - Eixo: Função/Papel do professor ..............................................................................

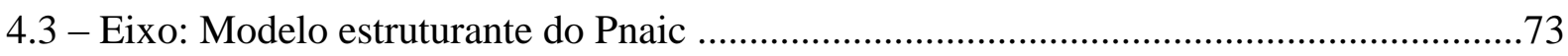

4.4 - Eixo: Concepções de alfabetização ........................................................................77

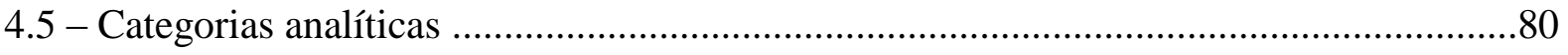

4.6 - Os cadernos de formação do Pnaic e os autores referenciados ........................................103

CONSIDERAÇÕES FINAIS .....................................................................................................112

REFERÊNCIAS BIBLIOGRÁFICAS .............................................................................. 116

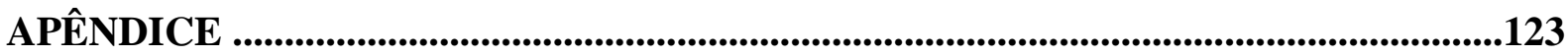

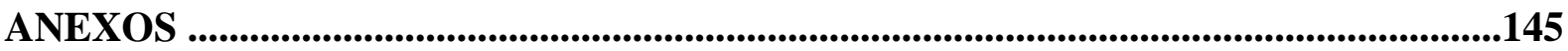




\section{INTRODUÇÃO}

Essa pesquisa origina-se a partir das experiências como professora alfabetizadora durante 21 anos na Secretaria de Estado de Educação do Distrito Federal (SEEDF), como formadora de professores em serviço no Centro de Referência em Alfabetização de Ceilândia e como orientadora de estudos do Pacto Nacional pela Alfabetização na Idade Certa (Pnaic) em 2013 e 2014.

Desde 2008 atuando como formadora de professores alfabetizadores nas escolas públicas de Ceilândia e a partir das discussões em grupo com os demais Articuladores do Centro de Referência em Alfabetização das demais Coordenações Regionais de Ensino da SEEDF, questiono sobre a importância da formação continuada e qual a melhor forma de sua estruturação para o desenvolvimento do trabalho docente com emancipação e autonomia.

A educação se constitui uma produção social e atua como difusora de cultura, representações e visões do mundo, de diferentes grupos sociais em cada período em que vai sendo construída como atividade humana. Compreender a educação em seus diversos enfoques permite estabelecer relações com o que foi se transformando na sociedade e com a própria estrutura educacional. Decorrente dessas transformações sociais, o tema da formação continuada de professores tem sido marcado por um grande número de iniciativas e de pesquisas, que pretendem trazer à tona ora o significado da expressão "formação continuada" ora os limites e possibilidades da formação continuada no processo de desenvolvimento profissional.

Destacamos a necessidade de uma política global de formação e valorização dos profissionais da educação que contemple de forma articulada e prioritária a formação inicial, continuada e condições de trabalho, salários e carreira, com a concepção sócio-histórica do educador a orientá-la na constituição da profissão docente.

As condições do trabalho pedagógico na escola pública demandam investimento público em políticas de profissionalização e formação continuada de professores, de qualidade elevada, para a educação básica, adequada às demandas contemporâneas da ciência, da cultura e do trabalho (ALARCÃO, 1996).

No entanto, as ações do Ministério da Educação (MEC) mobilizaram desde o final da década de 1990, diferentes políticas de formação continuada docente se pautando pela continuidade de programas de caráter continuado e compensatório; destinados à formação de professores alfabetizadores em exercício com cursos à 
distância ou semipresenciais em cooperação com os sistemas de ensino. Situam-se, nessa perspectiva, os programas vinculados à Rede Nacional de Formação Continuada de Professores, na qual se inserem os Centros de Pesquisa e Desenvolvimento da Educação.

Destacamos o Pró-Formação (1997-2004) direcionado à formação continuada de professores de $1^{\text {a }}$ a $4^{\text {a }}$ séries do ensino fundamental; o Programa de Formação de Professores Alfabetizadores (PROFA-2001), o Pró-Infantil (2005) dirigido à formação continuada dos professores de educação infantil e o Pró-Letramento (2008-2012) desenvolvido em parceria com os sistemas de ensino e com as universidades da Rede de Formação Continuada e Desenvolvimento da Educação, constituindo-se como um programa de formação continuada de professores dos anos iniciais do Ensino Fundamental centrado em alfabetização e matemática.

Recentemente, outro programa de maior abrangência relacionada à formação continuada de professores alfabetizadores foi implantado no Brasil. É o Pacto Nacional pela Alfabetização na Idade Certa (Pnaic), um compromisso formal assumido em 05 de julho de 2012 pelo Governo Federal, do Distrito Federal, dos estados e municípios de assegurar que todas as crianças estejam alfabetizadas até os oito anos de idade, ao final do $3^{\circ}$ ano do Ensino Fundamental; reafirmando o que propõe o Plano de Desenvolvimento da Educação (PDE) e o plano de metas Compromisso Todos pela Educação, previsto no Decreto 6.094/2007, especificamente no tocante ao inciso II do art. $2^{\circ}$. Para tanto, a política está estruturada em quatro eixos: formação continuada de professores alfabetizadores; materiais didáticos e literatura; avaliação; gestão, controle e mobilização social.

As ações do Pacto Nacional pela Alfabetização na Idade Certa são um conjunto integrado de programas, materiais e referências curriculares e pedagógicas disponibilizados pelo Ministério da Educação (MEC) que pretendem dar suporte ao processo de alfabetização e letramento, tendo como eixo principal a formação continuada de professores alfabetizadores.

Então, para compreender melhor os elementos constitutivos da formação continuada é necessário explorar fatos da realidade e entender sua fundamentação histórico-social; além das relações encontradas nas escolas, outras interações das esferas sociais e políticas que articuladas à educação e à totalidade social, interferem e consolidam a formação docente. 
Sendo assim, no primeiro semestre de 2014, cursando como aluna especial do Mestrado a disciplina "Tópicos em Formação do profissional da educação", do Programa de Pós-graduação em Educação da UnB; fui motivada a me inserir na pesquisa sobre a formação continuada de professores alfabetizadores.

O desejo de investigar a formação continuada dos professores alfabetizadores, participantes da formação continuada do Pacto Nacional pela Alfabetização na Idade Certa, possibilitou a escrita do pré-projeto de pesquisa e o ingresso no curso de Mestrado em Educação. A aproximação do objeto de pesquisa, o aprofundamento teórico nas disciplinas, os estudos coletivos e individuais, a participação em palestras e eventos; juntamente com os encontros de orientações; delimitaram a pesquisa, buscando qualificá-la, ponderando os limites, possibilidades e tendências.

Esta pesquisa objetivou contribuir para os estudos sobre a formação continuada de professores alfabetizadores, elegendo para análise a proposta formativa na área da alfabetização e letramento trazida pelo Pacto Nacional pela Alfabetização na Idade Certa (Pnaic). Sendo assim, será norteada pela seguinte questão de estudo: Quais concepções que norteiam a formação continuada desenvolvida no âmbito do Pnaic?

Dessa forma, temos como objetivo geral dessa pesquisa:

- Analisar as concepções de formação continuada que norteiam a formação continuada desenvolvida no âmbito do Pacto Nacional pela Alfabetização na Idade Certa (Pnaic).

E como objetivos específicos:

- Historicizar as concepções de formação continuada no processo de formação de professores alfabetizadores no Brasil.

- Analisar os documentos e elementos norteadores das políticas públicas de formação para professores alfabetizadores que se consolidaram no Pnaic.

Para tanto, a pesquisa constrói um Estado do Conhecimento do objeto em estudo e também realiza uma análise documental da Formação Continuada desenvolvida no âmbito do Pnaic oferecida aos professores alfabetizadores; tendo como princípio metodológico o materialismo histórico e dialético, na condição de compreender as 
concepções de formação continuada que legitimam e sustentam essa formação docente. A pesquisa pode fornecer categorias para estudo e reflexão da prática profissional do professor e o seu processo de formação continuada. Segundo Curado Silva (2008) são elementos que podem articular teoria e prática mediadas pelo trabalho e pela práxis.

Sendo assim, a dissertação está estruturada em quatro capítulos. O primeiro capítulo - Construindo o objeto de pesquisa - tem como objetivo apresentar o percurso metodológico da pesquisa, considerando o materialismo histórico e dialético como princípio norteador de toda análise do objeto em estudo.

O segundo capítulo, intitulado - Estado do conhecimento: outros olhares sobre o Pnaic - descreve um mapeamento bibliográfico com informações substanciais da formação continuada do Pnaic abordadas em outras pesquisas realizadas sobre o nosso objeto de estudo.

O terceiro capítulo, denominado - Políticas públicas de formação continuada de professores alfabetizadores e o Pacto Nacional pela alfabetização na idade certa - historiciza as concepções de formação continuada no processo de formação de professores alfabetizadores, analisando os elementos norteadores das políticas públicas de formação docente no Brasil.

E por fim, o quarto capítulo - O Pacto Nacional pela alfabetização na idade certa: analisando as concepções de formação continuada - apresenta uma análise documental dos documentos oficiais e Cadernos de formação do Pnaic, na condição de analisar as concepções que norteiam, legitimam e sustentam a formação continuada desenvolvida no âmbito dessa política pública de educação.

Considerando nosso objeto de pesquisa e nosso percurso metodológico, buscamos contribuir para a compreensão e intervenção na formação continuada de professores alfabetizadores, construindo diálogos que articulem teoria e prática na formação; numa perspectiva de compromisso social, político e ético, voltado para uma sólida concepção teórica. Espera-se, também como produto dessa pesquisa, a construção de uma prática social para a investigação e intervenção nos processos de formação docente dos professores. 


\section{CAPÍTULO 1 - CONSTRUINDO O OBJETO DE PESQUISA}

\section{1 - Percurso metodológico da pesquisa}

Tendo como objetivo principal analisar as concepções que norteiam a formação continuada desenvolvida no âmbito do Pacto Nacional pela Alfabetização na Idade Certa (Pnaic), defini-se o materialismo histórico e dialético como princípio metodológico dessa pesquisa; priorizando a história dos fenômenos no movimento da totalidade social, significando assim, entre outras questões, a possibilidade de perceber as condições concretas para a objetivação do gênero humano na individualidade dos sujeitos e a superação das condições constituídas na realidade atual. O materialismo histórico e dialético mobiliza um contínuo e complexo caminho em direção à formação da consciência crítica, jamais de modo finito ou conclusivo.

Nessa perspectiva, se destaca, num primeiro momento, a importância de considerar o trabalho dos professores alfabetizadores participantes da formação do Pnaic e de seus formadores como sujeitos imprescindíveis da pesquisa, ou seja, tomar como ponto de partida $o$ ser social que está presente nessa relação educativa.

No sentido de identificar as dimensões que perpassam essa formação continuada de professores, considerando toda a análise documental; propõe-se por meio do materialismo histórico e dialético o qual permite compreender o contexto histórico e seus determinantes, concebendo a realidade a partir da apreensão de suas contradições na sua totalidade e tendo o trabalho como princípio ontológico do homem e desenvolvimento humano, a elaboração de um eixo teórico-metodológico de análise nessa pesquisa.

\section{2 - Método}

O Materialismo histórico é a ciência filosófica do marxismo que estuda as leis sociológicas que caracterizam a vida da sociedade, de sua evolução histórica e da prática dos homens, no desenvolvimento da humanidade. Esclarece conceitos como: ser social, “consciência social”, meios de produção, forças e relações de produção, os modos de produção, etc. e uma série de outros conceitos para compreensão de suas dimensões.

Os pressupostos da Teoria Social de Marx são estruturados a partir de três fontes: a Filosofia Clássica alemã (Hegel / Feuerbach), a Economia Política inglesa (Adam Smith/David Ricardo) e o Socialismo francês (Saint-Simon/ Charles 
Fourier/Robert Owen). Não se limitando à obra de seus precursores históricos, Karl Marx iniciou a sua contribuição teórica na década de 1840 revolucionando o pensamento filosófico, principalmente por causa de suas conotações políticas explícitas.

O materialismo dialético é a base filosófica do marxismo e como tal realiza a tentativa de buscar explicações coerentes, lógicas e racionais para os fenômenos da natureza, da sociedade e do pensamento. O pensar filosófico tem como propósito fundamental o estudo das leis mais gerais que regem a natureza, a sociedade e o pensamento e, como a realidade objetiva, se reflete na consciência; e para configurar sua concepção de mundo apoia-se na ciência. O materialismo dialético tem como categorias a matéria, a consciência e a Prática social, levantada como critério de verdade.

Segundo Gadotti (2010) a dialética em Marx não é apenas um método para se chegar à verdade, é uma concepção do homem, da sociedade e da relação homem-mundo. É o próprio homem que figura como ser produzindo-se a si mesmo, pela sua própria atividade, pela sua maneira de viver, isto é, pelo modo de produção da sua vida material.

A concepção materialista e dialética entende que, no estudo do desenvolvimento de um objeto deve-se partir do seu conteúdo interno, das suas relações com outros objetos; considerando as ligações, as interações e as contradições entre eles. A dialética concebe as coisas e os fenômenos não de maneira estática, mas no seu movimento contínuo, na luta de seus contrários.

A dialética como processo e movimento de reflexão da formação continuada de professores não visa apenas conhecer e interpretar a realidade em que essa formação está inserida, mas por transformá-la no interior da história da profissão docente. É por isso que nossa reflexão só adquire sentido quando ela é um momento, uma singularidade da práxis social humana.

Por meio do materialismo histórico e dialético o homem busca explicações coerentes, lógicas e racionais para os fenômenos da natureza, da sociedade e do pensamento, essa busca é baseada na prática social da humanidade. Além de buscar explicar tais fenômenos, o materialismo dialético assumiu uma posição de teoria orientadora da revolução do proletariado.

Para Marx e Engels:

... a filosofia marxista não enfoca a prática como experiência sensorial subjetiva do indivíduo, como experimento do científico etc., mas como atividade, antes de tudo, como processo objetivo de produção material, que constitui a base da vida humana, 
e também como atividade transformadora revolucionária das classes e como outras formas de atividade social prática que conduzem à mudança do mundo (TRIVIÑOS, 2013,p. 64).

A abordagem crítico-dialética reconhece a ciência como produto da história, da ação do próprio homem, que está inserida no movimento das formações sociais. Nesse sentido, encara a ciência como uma construção decorrente da relação dialética entre o pesquisador e o objeto envolvidos em determinada realidade histórica.

Como concepção dialética, o marxismo não separa a teoria/conhecimento da prática/ação, tendo a teoria como guia para a ação. A prática é o critério da verdade da teoria, pois o conhecimento parte da prática e a ela volta dialeticamente. Assim, a perspectiva materialista histórico-dialética revela uma aproximação da escolha pela cientificidade da realidade, à medida que o processo de construção do conhecimento vai do todo para as partes e depois das partes para o todo realizando um círculo de síntese conforme o contexto.

Segundo Marx e Engels (2007), ao se propor um novo olhar sobre a realidade social, à luz dos fundamentos do materialismo histórico-dialético; é necessário ressaltar a função social do conhecimento no sentido de enriquecer a própria existência humana - a práxis em sua dimensão transformadora.

O materialismo histórico e dialético se efetiva no campo educacional pela práxis, isto é, unidade de teoria e prática na busca da transformação e de novas sínteses no plano do conhecimento e no plano da realidade histórica. É na práxis que o homem deve demonstrar a verdade, isto é, a realidade e o poder, o caráter terreno de seu pensamento. Não a práxis como prática estritamente utilitária, reduzindo o verdadeiro ao útil; mas sim, a práxis como ação transformadora, considerando o homem um ser criador, sujeito da história, que se transforma na medida em que transforma o mundo.

Tomando nosso objeto de estudo, a formação continuada de professores como política e prática transformadora, numa perspectiva contextualizada e real, busca-se o entendimento das concepções presentes no programa do Pacto Nacional pela Alfabetização na Idade Certa; relacionando o singular e o todo, o social e o histórico, o político e o educacional, o concreto e o contraditório nessa relação.

Para Netto (2011) o materialismo histórico e dialético é o método de pesquisa que propicia o conhecimento teórico, partindo da aparência, visando alcançar a essência do objeto de análise. Alcançando a essência do objeto investigado, o pesquisador 
reproduz a aparência no plano ideal. Nesse processo, os instrumentos e também as técnicas de pesquisa são os mais variados, desde a análise documental até as formas mais diversas de observação, levantamento de dados, etc.

A abordagem de pesquisa a partir do materialismo histórico e dialético surge ante a necessidade de estudar numa perspectiva crítica a educação escolar brasileira, a relação educação e sociedade, a relação teoria e prática no exercício profissional dos educadores e a escola vinculada ao Estado (GAMBOA, 2012).

O homem como ser social e individual, que para produzir e reproduzir sua existência se apropria da cultura, faz escolhas alternativas e realiza atividades. Assim, ele conserva o patrimônio e o legado histórico produzido socialmente e se reproduz, bem como sua ação ocorre pela incorporação de experiências e conhecimentos produzidos e transmitidos pela humanidade. Nesse processo de desvendamento, a realidade não é mais naturalizada, mas historicizada, sendo considerada como produto da práxis humana; pois o fenômeno histórico é o fenômeno dos processos dessa práxis.

Segundo Cury (1987) captar o fenômeno na sua essência não é negar o fenômeno, mas destruir sua pretensa independência e ressaltar sua conexão e unidade com a essência através de oposições e mediações.

Como pretendemos analisar as concepções que norteiam a formação continuada desenvolvida no âmbito do Pnaic, precisamos analisar o percurso histórico de formação dos professores alfabetizadores, bem como suas práticas sociais; elencando alguns elementos reais e concretos que venham a contribuir para o desenvolvimento de um pensamento crítico, dialético e consistente para a formação docente no Brasil.

\section{3 - Categorias do método}

Entendemos que o objeto aqui especificado - concepções de formação continuada desenvolvida no âmbito do Pnaic - é carregado de intencionalidades, ou seja, de projetos sociais e ações políticas de formação docente.

A escolha do materialismo histórico e dialético como método para nossa pesquisa; permitiu e contém a possibilidade de sistematizar e analisar tais intencionalidades, e ao mesmo tempo, propor novas concepções de formação de professores, que contenham elementos de emancipação em sua base, bem como, emancipação do sujeito docente e do sujeito formado. 
Para Marx (2008), a educação é o processo pelo qual os homens tomam consciência de seu ser social e da necessidade de sua superação.

Assim, elencamos para nossa análise e estudo, a princípio, as categorias trabalho, contradição, totalidade, historicidade e mediação. Essas categorias metodológicas são constitutivas da teoria, são os conceitos fundamentais para o conhecimento do real, para analisar a essência da formação continuada de professores e também contribuem para a análise das políticas públicas de educação por possibilitar a compreensão de que elas emergem da práxis humana, a qual está fundada, na sociedade capitalista, em relações sociais antagônicas.

O trabalho, referenciado por Marx, tem a capacidade de modificar o sujeito da atividade, o homem, o gênero humano, a natureza e o meio social. A condição para que o homem se torne homem é o trabalho. A mediação entre ele e o mundo se realiza pela atividade material.

O trabalho, como criador de valores de uso, como trabalho útil, é indispensável à existência do homem - quaisquer que sejam as formas de sociedade - é necessidade natural e eterna de efetivar o intercâmbio material entre o homem e a natureza, e, portanto, de manter a vida humana (MARX, 1982, p. 50).

O trabalho para Marx assume duas dimensões distintas e sempre articuladas: trabalho, como mundo da necessidade, considerando a produção de meios para manutenção da vida biológica e social; e trabalho como mundo da liberdade, constituindo-se como elemento criador da vida humana, um dever e um direito, ou seja, como princípio educativo.

Ao longo da humanidade, com a emergência da sociabilidade capitalista, o trabalho vem perdendo capacidade de humanização, em sentido antropológico; no entanto, continua interferindo profundamente na vida do homem e na reprodução da sociedade. O trabalho é a base ontológica do ser e a educação é um trabalho imaterial.

Marx (2008) investiga, entre outras questões, a riqueza existente no modo de produção capitalista e, com a análise da mercadoria, explica que, com o desenvolvimento das forças produtivas do trabalho, aumenta a quantidade de valores de uso (de mercadorias) e diminui o valor da massa de riqueza da mercadoria. As contradições da mercadoria expressam as contradições do movimento do capital e o seu caráter fetichista. 
Assim, Frigotto (2002) destaca o trabalho e a valorização deste, fornecendo a compreensão de que o atual meio de produzir a vida não é o único possível, nem uma realidade dada e predeterminada. $\mathrm{O}$ trabalho não se refere apenas à remuneração de uma tarefa, mas emerge como um direito. A ele, liga-se uma profissão e o direito à qualificação profissional, à formação continuada.

Compreendendo a forma como a economia nos é apresentada e desvendando suas contradições, chega-se à essência do trabalho na sociedade capitalista: o lucro, a competitividade e o individualismo. A educação e a ciência tornam-se propriedade privada, monopólio do capital. Então, o fundamento para a educação, nesse movimento de complexificação do homem; a escola, que é uma necessidade da sociabilidade, deve ser instrumento de formação, de crítica e emancipação.

As formas de organização da escola, além de ser expressão material do desenvolvimento social, econômico e cultural da sociedade, impuseram um jeito de ser e agir ao trabalho docente, que sendo coletivo, foi historicamente construído e formado pelas relações sociais que se desenvolveram no interior do processo de trabalho na escola. Essa relação social deve se materializar na relação entre o educador e o educando juntos na práxis revolucionária, por intermédio do mundo que transformam; resgatando a integração educação e o desenvolvimento do homem em todos os domínios da vida social, isto é, no trabalho, na política, na economia, na cultura.

Marx (1982) associa o ato produtivo com o ato educativo, explicando que a unidade entre a educação e a produção material deveria ser admitida como um meio decisivo para a emancipação do homem. A integração entre ensino e trabalho constitui-se na maneira de sair da alienação crescente, reunificando o homem com a sociedade.

Integrando o trabalho e a formação continuada, percebemos a relação dialética nesse movimento de construção da identidade e profissionalização docente. A formação é ação continuada e permanente. Nesse sentido, temos a tensão entre as políticas públicas para formação continuada de professores, com ações de formação em serviço, de produção de apoio e de reflexão sobre as práticas formativas; cuja finalidade seria a de produzir, antes de tudo, a melhoria do ensino através de mudanças na prática docente; e as condições de trabalho vivenciadas todos os dias pelos professores no ambiente escolar.

Assim, é importante e necessário, entender a relação entre a proposta de formação continuada do Pnaic e a organização do trabalho docente como elemento da materialidade do seu fazer e ser, ou seja, compreender como esse professor se constitui e 
se reconhece em seu trabalho. Dessa forma o trabalho mostra-se como categoria central de análise metodológica em nossa pesquisa.

Para se pensar em um projeto de formação de professores é preciso considerar a materialidade do trabalho docente, pois os homens são produzidos por meio do trabalho docente e só mudanças no nível das relações de trabalho podem transformar a realidade. A consciência, por si só, não constitui e nem altera a prática, mas ao desvelar a realidade produz possibilidades de novas práticas (CURADO SILVA e LIMONTA, 2014, p. 17).

Torna-se importante compreender como o sentido ontológico da categoria trabalho tem significado dentro da formação continuada, pois esta organização pedagógica está relacionada nas formas concretas da materialização do trabalho docente na escola e na sala de aula; refletindo a relação entre a função da escola e as dimensões, ou formas de manifestações que permeiam o trabalho docente. Por isso, Santos (2014) afirma que a formação como política e prática formadora se reveste de intencionalidade, ou seja, não há como pensar a formação docente desvinculada das funções estabelecidas para a educação e para os professores.

Segundo Alves (2011) é necessário que a compreensão e perspectiva de formação de professores esteja ligada à realidade escolar, aos conflitos econômicos e sociais, à crise da cultura, às demarcações político-ideológicas do Estado; numa visão de totalidade, de formação coletiva e em todos os níveis de formação. Considerar a formação docente na sua unidade dialética com a sociedade capitalista é considerá-la num processo de relações contraditórias. A divisão capitalista do trabalho é contraditória. De um lado libera a força de trabalho, de outro a transforma em mercadoria.

A categoria da contradição é base de uma metodologia dialética. Não podemos negar a contradição no movimento do real e do histórico. Cada fenômeno exige a existência do seu contrário, como determinação e negação do outro. Tudo tem um caráter relacional, e nesta relação, o movimento e o transformar-se é a dinâmica da contradição.

A articulação de um discurso pedagógico a partir da contradição possibilita a percepção do caráter contraditório da própria educação, das suas possibilidades e limites. A possibilidade de ultrapassar os discursos pedagógicos que ocultam ou escamoteiam o real está na descoberta do caráter contraditório das mesmas relações que esses discursos pretendem encobrir (CURY, 1987, p. 24). 
A contradição, como sendo uma categoria interpretativa e existente no movimento do real, possibilita perceber as relações que possuem significação essencial para o conhecimento da formação continuada de professores; pois ao mesmo tempo em que essa formação pode frear o desenvolvimento profissional docente, pode contribuir, em alguma medida, para fazer avançar no seu desenvolvimento e emancipação. É necessário refletir sobre esse fenômeno descobrindo as contradições existentes nele e relacionando as particularidades e especificidades da totalidade histórica no qual se insere.

A formação continuada docente, como os outros fenômenos sociais da realidade, contém a tensão entre o ser e não ser, ou seja, pode trazer elementos que constituam um novo ser professor; com possibilidades emancipatórias em relação ao seu trabalho, ou reafirmar o não ser alienado. A contradição é uma categoria que possibilita ver o movimento da formação continuada. E essa formação continuada vai apresentar ao mesmo tempo alguns fenômenos contraditórios, pois o professor que passa por essa formação, jamais será o mesmo. Mesmo que o modelo de formação continuada não seja o ideal, possibilita nessa análise contraditória, percebermos elementos importantes para a constituição docente, tais como: trabalho coletivo, compartilhar de experiências entre os pares, movimento de ir e vir no processo, reflexão e transformação.

Em nossa análise sobre a formação continuada docente, os fatos históricos, econômicos, de relações de poder e de produção, de luta de classes; são elementos contraditórios, que se relacionam ao sujeito da práxis, que é o homem, ser ativo, mediador e mediado desse processo e criador da realidade social. Assim, a categoria da contradição, numa perspectiva dialética, relaciona-se à categoria da totalidade, pois a totalidade sem contradição é vazia, estanque; e as contradições fora da totalidade são arbitrárias.

Segundo Cury (1987) a totalidade não é um todo já feito, determinado e determinante das partes, não é uma harmonia simples, pois não existe uma totalidade acabada, mas um processo de totalização a partir das relações de produção e de suas contradições.

A compreensão dialética da totalidade não quer dizer análise de todos os fatos e nem a soma de partes, mas sim, a relação entre as partes e o todo e as partes entre si. Portanto, a totalidade é concreta. O pensamento dialético parte do pressuposto de que a realidade é um todo dialético e estruturado, e que o conhecimento concreto da realidade, 
é um processo de concretização que precede do todo para as partes e das partes para o todo, dos fenômenos para a essência e da essência para os fenômenos, da totalidade para as contradições e das contradições para a totalidade; e justamente neste processo de correlações em espiral no qual todos os conceitos entram em movimento recíproco e se elucidam mutuamente, atinge a concreticidade (KOSIK, 1986, p. 41).

Do ponto de vista da totalidade concreta, compreender a formação continuada de professores significa que cada momento de formação pode ser compreendido como momento do todo; e que esse momento social é um fato histórico na medida em que é analisado como momento de um determinado todo; definindo a si mesmo e definindo o todo. Assim, qualquer formação continuada não consiste em uma ação isolada, ela é de forma explícita e implícita, parte de um projeto para a escola, para o professor e para o aluno, sempre considerando sua função e sentido; ou seja, investe-se num projeto de sociedade. Portanto, buscar o todo é ir além de olhar tudo que envolve tal projeto, mas revelar as singularidades dessa parte com sua relação num projeto de professor, escola e sujeito social.

Concebendo a formação continuada docente como um todo estruturado que se desenvolve e se cria a si mesmo na interação das partes, nossa análise deve ter como ponto de partida sua presença imanente numa totalidade histórica e social. A formação docente, como atividade humana partícipe da totalidade da organização social, exige que se considere como historicamente determinada por um modo de produção dominante, em nosso contexto, o capitalista. A totalidade concreta implica, portanto, a historicização dos fenômenos.

O professor é um sujeito histórico-social que, pela sua práxis, produz a realidade e também é produzido por ela, possibilitando o conhecimento da mesma. A práxis docente representa a atividade livre, criativa, por meio da qual é possível transformar o mundo humano e a si mesmo. Ela não é atividade prática contraposta à teoria, é determinação da existência humana como criação da realidade, articulando o professor e a totalidade do trabalho docente. Assim, o conjunto totalizante das relações sociais, históricas, econômicas, políticas e ideológicas busca uma compreensão global do processo de formação docente.

O homem não é apenas uma parte da totalidade do mundo: sem o homem como parte da realidade e sem o seu conhecimento como parte da realidade, a realidade e o seu conhecimento não passam de mero fragmento. Já a totalidade do mundo 
compreende ao mesmo tempo, como momento da própria totalidade, também o modo pelo qual a realidade se abre ao homem e o modo pelo qual o homem descobre esta totalidade (KOSIK, 1986, p. 206).

Sendo assim, a categoria da totalidade exige relações contraditórias e mediações que articule o movimento histórico e os homens concretos, implicando no reconhecimento do real como histórico. Essas relações remetem-nos à categoria da historicidade. Uma política de formação de professores alfabetizadores como a proposta pelo Pacto Nacional pela Alfabetização na Idade Certa só poderá ser essencialmente apreendida se for analisada em sua historicidade, ou seja, em sua gênese e seu desenvolvimento histórico. Para Marx (1978) a gênese não explica o estado atual, porém permite identificar a diferenciação (sua particularidade) em sua evolução. Ela é fundamental para a compreensão do fenômeno, porém não é, em absoluto, a essência do fenômeno em sua expressão mais desenvolvida. A realidade é um processo, pois há nela uma dinâmica imanente constitutiva do mundo histórico-social.

A história do tempo presente exige o domínio da historicidade que se produziu e produz sobre a formação continuada de professores. É necessário conhecer e dar a conhecer o debate das interpretações sobre esse fenômeno estudado, revelando a incompletude e as contradições desse real concreto. A proposta de formação continuada que estudamos certamente vai mostrar que só é possível compreendê-la quando posta em relação com outros objetos, aspectos e fenômenos que caracterizam o contexto histórico; pois não se pode apreender o projeto de formação sem compreender e localizar sua relação com a história. Uma história humana de projeto de homem, sociedade e formação profissional.

O conhecimento da realidade histórica é um processo de apropriação teórica, isto é, de crítica, interpretação e avaliação de fatos. O conhecimento teórico é o que subsidiará a prática pedagógica. A periodização deve ter seu marco na lógica do próprio objeto em estudo. Segundo Kosik (1986), para o materialismo histórico e dialético a realidade social pode ser conhecida na sua totalidade quando se descobre a natureza da realidade social como unidade dialética de base, e o homem como sujeito objetivo e histórico-social. Assim a realidade humana não é apenas produção do novo, mas também reprodução crítica e dialética do passado e da relação com o presente.

A relação entre educação e poder acompanha o desenvolvimento de toda história das ideias pedagógicas. O processo de formação continuada docente não é inato, exige 
esforço e atuação de elementos externos e internos. O professor é resultado de muitas determinações, num processo de descobertas e de ação sobre elas. Esse processo é real e histórico. Como o materialismo histórico e dialético parte do movimento, da mudança, da ação, exige-se uma constante revisitação e reconstrução da teoria; pois este enfoque parte da historicidade do fenômeno e, por se tratar de conhecimento histórico, é parcial, provisório e relativo, necessitando ser revisitado e reconstruído constantemente.

Marx (1978) afirma que se compreendermos a empiria como "gestada" na história, como manifestação da consciência humana nesta, e se tomamos como passível de conhecimento pelo sujeito histórico, podemos considerar que conhecê-la é conhecer a própria consciência do homem. Em síntese, expressam vida, conflitos, lutas, interesses, projetos políticos, a história do homem.

E como tudo que é natural deve nascer, assim também o homem possui seu ato de nascimento: a história, que, no momento, é para ele uma história consciente, e que, portanto, como ato de nascimento acompanhado de consciência é ato de nascimento que se supera (MARX, 1978, p. 41).

Portanto, se faz necessário, pela categoria da historicidade, analisar o percurso histórico da formação continuada dos professores alfabetizadores, bem como suas práticas sociais; na perspectiva de compreender a concepção de formação do Pacto Nacional pela Alfabetização na Idade Certa no processo de profissionalização docente. Nesse percurso de historicização da formação continuada de professores alfabetizadores, a categoria da mediação permite uma conexão dialética de todos os elementos presentes nesse processo, indicando que a formação docente não é um fenômeno isolado do contexto histórico, político, sócio-econômico.

A mediação deve ser ao mesmo tempo relativa ao real e ao pensamento, buscando captar um fenômeno no conjunto de suas relações com os demais fenômenos. A mediação permite compreender o professor inserido na sociedade, suas possibilidades e seus limites, de modo geral, e, em particular, as questões próprias à educação. Segundo Cury (1987) a educação possui, antes de tudo, um caráter mediador porque, no seu sentido amplo, filtra uma maneira de ver as relações sociais; capaz de viabilizar uma estruturação ideológica para um determinado modo de produção, que por sua vez, tende a assegurar a dominação de classe pela burguesia. 
Nesse sentido histórico e contraditório da produção, a formação continuada de professores tem o caráter mediado e mediador no processo social. Como mediadora, embora em níveis diferentes, pode possibilitar a construção da autonomia, consciência crítica e emancipação; e como mediada pode permitir a desarticulação e alienação. A formação docente como mediadora torna-se um valioso instrumento de apoio na transformação social, pois a apropriação de um conhecimento revelador torna-se momento de denúncia de um saber dissimulador das contradições, revelando as possibilidades de novas relações sociais, mais autônomas e crítico-emancipadoras.

A formação continuada de professores alfabetizadores, enquanto elaboração, incorporação e transmissão de conhecimentos, valores, ideias e crenças; nasce do fazer pedagógico, do trabalho docente e para ele se volta. Essa formação torna-se mediadora entre duas ações, um saber anterior que conduz a um novo saber, ou seja, um ser docente que pode se transformar em um novo ser docente. Assim, a mediação possibilita entender a formação continuada docente num processo de organização da consciência, avançando na conquista de uma maturidade ideológica e de valorização do trabalho docente.

\section{4 - Etapas da pesquisa}

Para a primeira fase de análise da proposta de formação continuada docente desenvolvida no âmbito do Pacto Nacional pela Alfabetização na Idade Certa, fez-se necessário uma análise bibliográfica para conhecer, estudar e pesquisar todo material utilizado durante o curso, os documentos oficiais que norteiam essa referida ação de política pública; bem como o Estado do Conhecimento do objeto de pesquisa proposto. Segundo Rêses (2015) esse enfoque tende a analisar o real a partir do seu desenvolvimento histórico, da sua gênese e desenvolvimento, captando as categorias mediadoras que possibilitam a sua apreensão numa totalidade.

$\mathrm{Na}$ segunda fase da pesquisa, por meio de análise documental foi possível analisar as concepções que norteiam a formação continuada desenvolvida no âmbito do Pnaic, vivenciadas pelos professores alfabetizadores, bem como, os elementos norteadores das políticas públicas implantadas com o objetivo de assegurar que todas as crianças estejam alfabetizadas até os oito anos de idade, ao final do $3^{\circ}$ ano do Ensino Fundamental. O caminho do conhecimento, portanto, parte da aparência para a essência, essencialidade que é histórica e aberta e que constitui uma verdade histórica; com 
enfoque num referencial consistente numa perspectiva que busca revelar os movimentos do real numa análise de política pública.

Para Gamboa (2008), no materialismo histórico e dialético, a relação sujeito e objeto é entendida como uma relação dialética. O princípio da interação existente entre os eixos da relação cognitiva é produzido no enquadramento da prática social do sujeito, que captura e dialoga com o objeto na e pela sua atividade, cujo conhecimento diz respeito primeiramente à historicidade do sujeito e do objeto. No processo de conhecimento dessa realidade histórica, o que importa fundamentalmente não é o conhecer pelo conhecer, mas a dialética entre o conhecimento e a crítica para uma reflexão teórica em função da ação para transformar.

\section{5 - Análise documental}

No processo de delineamento da nossa pesquisa, analisamos os documentos oficiais e todo material utilizado na formação continuada dos professores alfabetizadores no Pacto Nacional pela Alfabetização na Idade Certa. Esse plano de pesquisa seleciona categorias metodológicas (trabalho, contradição, totalidade, historicidade e mediação) já explicitadas anteriormente; eixos de análise, pré-indicadores e indicadores a serem relacionadas com as categorias de análise documental, e as inferências que podem ser extraídas dos documentos analisados. Como eixos de análise definimos: I) Papel/Função da formação continuada, II) Função/Papel do professor, III) Modelo estruturante do PNAIC, IV) Concepções de alfabetização; a partir dos quais analisamos os préindicadores e indicadores retratados nos documentos estudados, considerando os temas e elementos abordados, a materialidade do objeto de análise e as categorias que emergem do mesmo.

Segundo Thompson (1981) o pesquisador deriva do corpus documental sua abordagem e da empiria retira elementos para sua intelecção e ação. Para isso ele problematiza suas inferências e busca encontrar o sentido dos documentos e com eles construir conhecimentos que permitam não apenas o entendimento da fonte, mas dos projetos históricos ali presentes e de suas perspectivas.

A análise documental, enquanto instrumento metodológico de investigação da realidade social considera o referencial teórico que nutre a pesquisa, pois, não só os documentos escolhidos, mas a análise deles deve responder aos objetivos da pesquisa, estabelecendo relações entre os documentos e seu contexto histórico. Segundo Shiroma 
(2007) o documento é histórico e concreto. Ele precisa ser entendido dentro de seu momento histórico. Como produto de uma sociedade, ele manifesta a força dos que detêm o poder. Não são produções isentas, mas traduzem leituras e modos de interpretação do vivido por um determinado grupo de pessoas em um dado tempo e espaço.

Portanto, a análise documental permite a investigação de determinado fenômeno não em sua interação imediata, mas de forma indireta, por meio do estudo dos documentos que são produzidos pelo homem e por isso revelam o seu modo de ser, viver e compreender um fato social. Os documentos de uma política pública de educação expressam o movimento dessa política e não apenas mostram o seu nascimento ou desfecho. Eles são ponto de partida para compreender a política pública, sendo produto e produtores de suas orientações. Por isso é necessário, que a análise documental, seja também uma análise de conceitos, que permita o entendimento dessa política pública; captando a sua essência e a sua materialidade para a sociedade.

Assim, quanto às categorias de análise documental elencamos: I) Concepções de formação continuada docente (epistemologia da racionalidade técnica, epistemologia da prática e epistemologia da práxis); II) Relação teoria e prática; III) Estrutura da formação. Como buscamos analisar as concepções que norteiam a formação continuada desenvolvida no âmbito do Pnaic foi necessário, em nossa análise documental, o diálogo com essas bases epistemológicas desencadeadas nas últimas décadas que orientaram e orientam a formação docente; bem como identificar e analisar a relação teoria e prática presente nos Cadernos de Formação do Professor Alfabetizador e a proposta de organização dessa formação continuada.

Quanto às concepções de formação continuada docente, de acordo com Silva (2008) a epistemologia da racionalidade técnica esteve muito presente na década de 1970 até meados da década de 1980 em nossos cursos de formação inicial e continuada de professores. Essa perspectiva de formação fundamenta-se na valorização da teoria em detrimento da prática, em formas tradicionais de conhecimento científico, sistemático e normatizado; elevado grau de racionalização da formação docente e secundarização da experiência prática do professor.

Para Zeickner (1998) a epistemologia da prática se constitui em um conjunto de críticas ao paradigma da racionalidade técnica, buscando um novo modelo teórico para a formação de professores a partir da década de 1990. Schön (2000) afirma que essa perspectiva propõe uma formação que disponha de um currículo que permita ao professor tornar-se um prático-reflexivo, evidenciando a prática pedagógica como eixo estruturante 
da formação e valorização da experiência prática do professor. Percebemos assim, que a reflexão sobre a prática pedagógica propõe uma perspectiva pragmática de reflexão, buscando a adequação do ensino e do professor às exigências das reformas das políticas neoliberais nesse contexto histórico.

A educação básica e a formação de novas competências, aparecem, nesse contexto das políticas neoliberais, nos documentos políticos e sociais, como elementos basilares e asseveradores da melhoria dos padrões de produtividade e competitividade dos países, especialmente daqueles, que ainda não superaram os desafios educacionais postos pela modernidade de universalização da escola para todos. Busca-se desenvolver um sistema estreitamente imbricado com as necessidades do mercado de trabalho e capaz de garantir a otimização dos esforços formativos. Assim, a formação docente tem como foco a prática pedagógica e a reflexão sobre essa prática, tomando a noção de competência como fundamento, remetendo muitas vezes para a iniciativa privada o controle e a oferta das ações de qualificação profissional.

Curado Silva (2008) afirma que a epistemologia da práxis é a teoria de uma prática pedagógica que procura não esconder o conflito, a contradição, mas, se inspirando na dialética, os afronta, buscando revelá-los na essência. E essa teoria constrói um caminho da prática à teoria e da teoria à prática, num processo dinâmico e permanente como a própria vida; possibilitando uma reflexão voltada à construção da emancipação e autonomia docente.

\footnotetext{
A práxis contém as dimensões do conhecer (atividade teórica) e do transformar (atividade prática), ou seja, teoria e prática são indissociáveis: “[...] fora dela fica a atividade teórica que não se materializa [...]. No entanto, não há práxis como atividade puramente material, sem a produção de finalidades e conhecimentos que caracteriza a atividade teórica" (VÁZQUEZ, 2011, p. 147).
}

Por isso, no processo de organização da análise documental e da definição de categorias que emergiram do nosso objeto de pesquisa, formulamos hipóteses e elaboramos indicadores que fundamentam a interpretação final do nosso estudo. Há uma expectativa de que a concepção de formação continuada esteja implícita na elaboração metodológica dos cadernos em todos os anos ( $1^{\circ}$ ao $3^{\circ}$ anos do Ensino Fundamental), portanto, a leitura documental se concentra no aspecto da concepção de formação; ou seja, como foi concebida, pensada, compreendida e articulada a proposta da organização 
metodológica de formação continuada no Pnaic, e em que tipo de professor se pretende formar.

\section{QUADRO 1 - PERCURSO METODOLÓGICO DA PESQUISA}

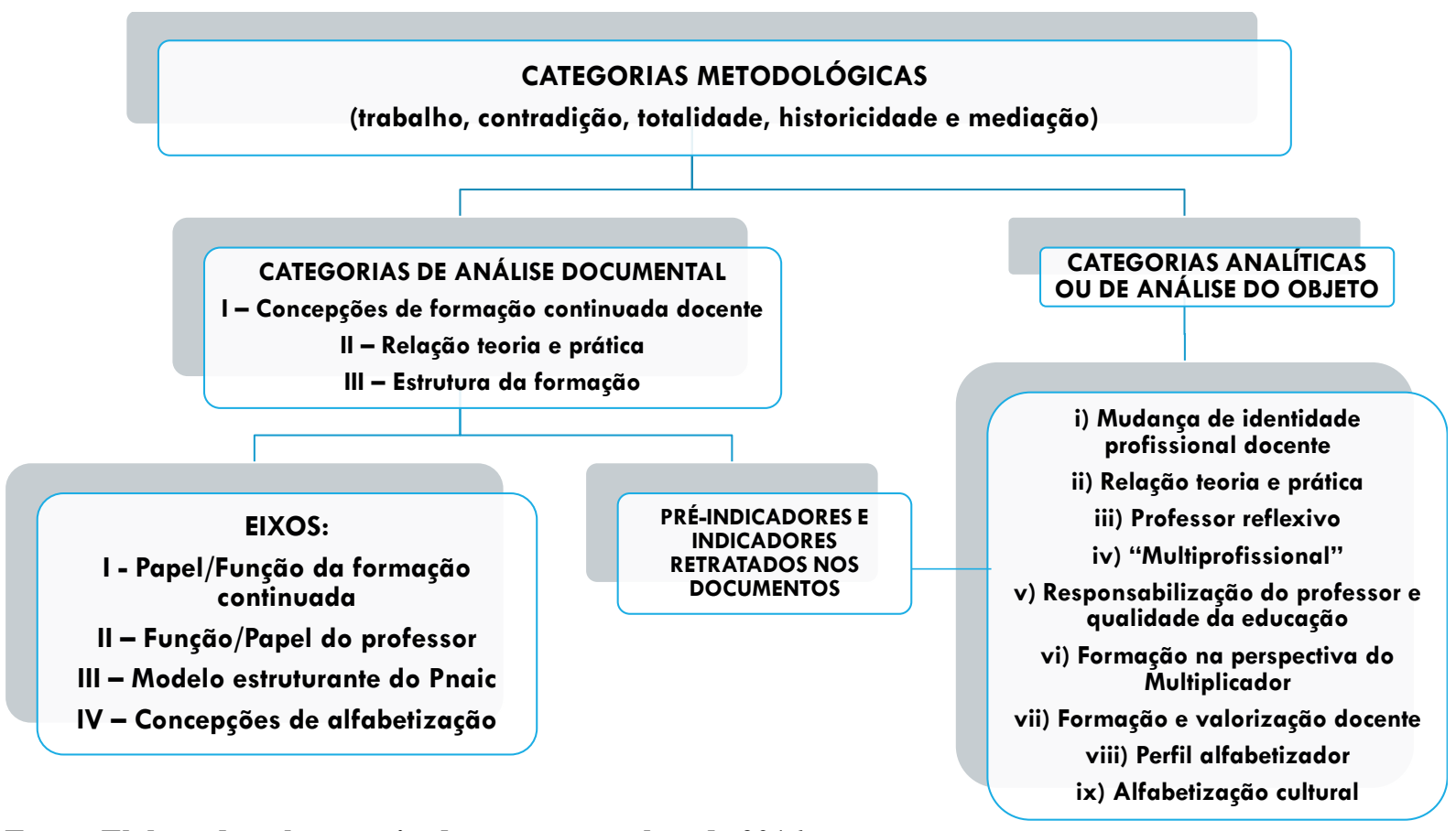

Fonte: Elaborado pela pesquisadora em novembro de 2016.

Assim, para a análise documental sobre a formação continuada desenvolvida no âmbito do Pacto Nacional pela Alfabetização na Idade Certa elencamos os seguintes documentos:

Documentos legais:

- $\quad$ Portaria no 867 de 4 de julho de 2012 - Institui o Pacto Nacional pela Alfabetização na Idade Certa e define suas diretrizes gerais.

- $\quad$ Medida Provisória no 586 de 8 de novembro de 2012 - Dispõe sobre o apoio técnico e financeiro da União aos entes federados no âmbito do Pacto Nacional pela Alfabetização na Idade Certa e dá outras providências.

- $\quad$ Portaria no 1458 de 14 de dezembro de 2012 - Define categorias e parâmetros para a concessão de bolsas de estudo e pesquisa no âmbito do Pacto Nacional pela Alfabetização na Idade Certa, na forma do art. $2^{\circ}$, inciso I, da Portaria MEC n ${ }^{\circ} 867$, de 4 de julho de 2012. 
- $\quad$ Resolução no 4 de 27 de fevereiro de 2013 - Estabelece orientações e diretrizes para o pagamento de bolsas de estudo e pesquisa para a Formação Continuada de Professores Alfabetizadores, no âmbito do Pacto Nacional pela Alfabetização na Idade Certa.

- $\quad$ Resolução no 12 de 8 de maio de 2013 - Altera dispositivos da Resolução CD/FNDE $n^{\circ} 4$ de 27 de fevereiro de 2013, que estabelece orientações e diretrizes para o pagamento de bolsas de estudo e pesquisa para a Formação Continuada de Professores Alfabetizadores, no âmbito do Pacto Nacional pela Alfabetização na Idade Certa.

- $\quad$ Manual do Pacto Nacional pela Alfabetização na Idade Certa - Livreto 2013.

- Documento Orientador das Ações de Formação do Pacto Nacional pela Alfabetização na Idade Certa em 2014 - MEC

- Documento Orientador das Ações de Formação do Pacto Nacional pela Alfabetização na Idade Certa em 2015/2016 - MEC

- $\quad$ Plano Nacional de Educação - PNE 2014-2024 (Meta 5): Alfabetizar todas as crianças, no máximo, até o final do terceiro ano do Ensino Fundamental.

Documentos da Formação Continuada:

Cadernos de Formação - 2013:

Caderno de Apresentação - Formação de professores alfabetizadores no Pacto Nacional pela Alfabetização na Idade Certa

Caderno de Formação - Formação do professor alfabetizador

Caderno de Educação Especial - A alfabetização de crianças com deficiência: uma proposta inclusiva

Caderno de Avaliação - Avaliação no Ciclo de Alfabetização: reflexões e sugestões

Caderno 1 ( $1^{\circ}$ ano) - Currículo na alfabetização: concepções e princípios

Caderno 1 ( $2^{\mathbf{o}}$ ano) - Currículo no Ciclo de Alfabetização: consolidação e monitoramento do processo de ensino e aprendizagem

Caderno 1 ( $3^{\circ}$ ano) - Currículo inclusivo: o direito de ser alfabetizado

Caderno 2 ( $1^{\circ}$ ano) - Planejamento escolar: alfabetização e ensino da Língua Portuguesa 
Caderno 2 ( $2^{\mathbf{o}}$ ano) - Organização do planejamento e da rotina no ciclo de alfabetização na perspectiva do letramento

Caderno 2 ( $3^{\circ}$ ano $)$ - Planejamento e organização da rotina na alfabetização

Caderno 3 ( $1^{\circ}$ ano) - A aprendizagem do sistema de escrita alfabética

Caderno 3 ( $2^{\circ}$ ano) - A apropriação do sistema de escrita alfabética e a consolidação do processo de alfabetização

Caderno 3 ( $3^{\circ}$ ano) - O último ano do ciclo de alfabetização: consolidando os conhecimentos

Caderno 4 ( $1^{\circ}$ ano) - Ludicidade na sala de aula

Caderno 4 ( $2^{\circ}$ ano - Vamos brincar de construir as nossas e outras histórias

Caderno 4 ( $3^{\circ}$ ano $)$ - Vamos brincar de reinventar histórias

Caderno 5 ( $1^{\circ}$ ano) - Os diferentes textos em salas de alfabetização

Caderno 5 ( $2^{\circ}$ ano) - O trabalho com gêneros textuais na sala de aula

Caderno 5 ( $3^{\circ}$ ano) - O trabalho com os diferentes em sala de aula: diversidade e progressão escolar andando juntas

Caderno 6 ( $1^{\circ}$ ano) - Planejando a alfabetização: integrando diferentes áreas do conhecimento, projetos didáticos e sequências didáticas

Caderno 6 ( $2^{\circ}$ ano $)$ - Planejando a alfabetização e dialogando com diferentes áreas do conhecimento

Caderno 6 ( $3^{\circ}$ ano) - Alfabetização em foco: projetos didáticos e sequências didáticas em diálogo com os diferentes componentes curriculares

Caderno 7 ( $1^{\mathbf{o}}$ ano) - Alfabetização para todos: diferentes percursos, direitos iguais Caderno 7 ( $2^{\circ}$ ano) - A heterogeneidade em sala de aula e os direitos de aprendizagem no ciclo de alfabetização

Caderno 7 ( $3^{\circ}$ ano) - A heterogeneidade em sala de aula e a diversificação das atividades

Caderno 8 ( $\mathbf{1}^{\mathbf{0}}$ ano) - Organização do trabalho docente para promoção da aprendizagem 
Caderno 8 ( $2^{\circ}$ ano) - Reflexões sobre a prática do professor no Ciclo de Alfabetização: progressão e continuidade das aprendizagens para a construção do conhecimento por todas as crianças

Caderno 8 ( $3^{\text {o }}$ ano) - Progressão escolar e avaliação: o registro e a garantia da continuidade das aprendizagens no Ciclo de Alfabetização

Caderno 1 (Educação do Campo) - Currículo no Ciclo de Alfabetização: perspectivas para uma Educação do Campo

Caderno 2 (Educação do Campo) - Planejamento do ensino na perspectiva da diversidade

Caderno 3 (Educação do Campo) - Apropriação do sistema de escrita alfabética e a consolidação do processo de alfabetização em escolas do campo

Caderno 4 (Educação do Campo) - Brincando na escola: o lúdico nas escolas do campo

Caderno 5 (Educação do Campo) - O trabalho com gêneros textuais em turmas multisseriadas

Caderno 6 (Educação do Campo) - Projetos didáticos e sequências didáticas na Educação do Campo: a alfabetização e as diferentes áreas do conhecimento escolar Caderno 7 (Educação do Campo) - Alfabetização para o campo: respeito aos diferentes percursos de vida

Caderno 8 (Educação do Campo) - Organizando a ação didática em escolas do campo

- Cadernos de Formação - 2014:

Caderno de Apresentação - Alfabetização Matemática

Caderno de Educação Inclusiva

Caderno Jogos na Alfabetização Matemática

Caderno 1 - Organização do trabalho pedagógico

Caderno 2 - Quantificação, registros e agrupamentos

Caderno 3 - Construção do sistema de numeração decimal

Caderno 4 - Operações na resolução de problemas

Caderno 5 - Geometria

Caderno 6 - Grandezas e medidas 
Caderno 7 - Educação estatística

Caderno 8 - Saberes matemáticos e outros campos do saber

- Cadernos de Formação - 2015/2016

\section{Caderno de Apresentação}

Caderno para Gestores - Gestão Escolar no Ciclo de Alfabetização

Caderno 1 - Currículo na perspectiva da inclusão e da diversidade: as Diretrizes Curriculares Nacionais da Educação Básica e o Ciclo de Alfabetização

Caderno 2 - A criança no Ciclo de Alfabetização

Caderno 3 - Interdisciplinaridade no Ciclo de Alfabetização

Caderno 4 - A organização do trabalho escolar e os recursos didáticos na alfabetização

Caderno 5 - A oralidade, a leitura e a escrita no Ciclo de Alfabetização

Caderno 6 - A Arte no Ciclo de Alfabetização

Caderno 7 - Alfabetização matemática na perspectiva do letramento

Caderno 8 - Ciências da Natureza no Ciclo de Alfabetização

Caderno 9 - Ciências Humanas no Ciclo de Alfabetização

Caderno 10 - Integrando saberes 


\section{CAPÍTULO 2 - ESTADO DO CONHECIMENTO: OUTROS OLHARES SOBRE O PNAIC}

Na primeira fase dessa pesquisa, a revisão bibliográfica permitiu extrair informações substanciais da formação continuada docente desenvolvida no âmbito do Pacto Nacional pela Alfabetização na Idade Certa, organizando-as e interpretando-as segundo os objetivos da investigação proposta.

A fim de analisar as concepções que norteiam a formação continuada do Pnaic e historicizar as concepções de formação continuada presentes no processo de constituição dos professores no Brasil; fizemos um mapeamento utilizando 11 bases de pesquisa muito importantes para os estudos sobre educação e formação docente:

- $\quad$ Scientific Electronic Library Online (SCIELO-CNPQ)

- Instituto Brasileiro de Informação em Ciência e Tecnologia (IBCIT-Biblioteca Digital Brasileira de Teses e Dissertações)

- GOOGLE ACADÊMICO e GOOGLE

- $\quad$ Associação Nacional de Pós-graduação e Pesquisa em Educação (ANPED 2013)

- Associação Nacional de Pós-graduação e Pesquisa em Educação (ANPED REGIONAIS 2014)

- $\quad$ Encontro Nacional de Didática e Práticas de Ensino (ENDIPE 2014),

- $\quad$ Associação Nacional de Política e Administração da Educação (ANPAE 2015)

- $\quad$ Congresso Brasileiro de Alfabetização (II CONBALF-2015)

- $\quad$ Associação Nacional de Pós-graduação e Pesquisa em Educação (ANPED) 2015

- $\quad$ Revistas de Educação (Qualis A1, A2, B1, B2, B3, B4, B5)

Quanto às Revistas, encontramos artigos e reportagens nas seguintes: Revista Teoria e Prática da educação, Revista Educação Especial - UFSM, UNOESC \& Ciência - ACHS, Nova Escola - Editora Abril, Educação e Cidadania, Práticas de Linguagem, Colóquio - Revista do Desenvolvimento Regional (Faccat) - Taquara/RS, Revista Diálogos Interdisciplinares (GEPFIP) - Aquidauana/MS.

Para esse mapeamento trabalhamos com um levantamento a partir de palavraschave: formação de professores alfabetizadores, Pnaic, formação do Pnaic. Essas palavras foram escolhidas, tendo em vista nossos objetivos de pesquisa e a relação com nosso objeto. Partimos da totalidade que seria a formação continuada de professores 
alfabetizadores, até a particularidade da formação de professores alfabetizadores no Pnaic.

Outro elemento direcionador de nossa revisão bibliográfica foi o recorte temporal de 2013 até o presente momento. Tal recorte se deve pela implantação do Pnaic a partir desse período, e pelo mesmo ainda estar em vigência em 2015/2016.

No âmbito desse estudo, destacamos no Estado do Conhecimento do objeto de pesquisa proposto:

\section{QUADRO 2 - BASES DE PESQUISA - ESTADO DO CONHECIMENTO}

\begin{tabular}{|c|c|c|c|c|c|c|}
\hline $\begin{array}{l}\text { BASES DE } \\
\text { PESQUISA }\end{array}$ & TESES & DISSERTAÇÃO & MONOGRAFIA/TCC & ARTIGO & REPORTAGEM & PÔSTER \\
\hline SCIELO & - & - & - & - & - & - \\
\hline IBCIT & - & 2 & - & - & - & - \\
\hline $\begin{array}{c}\text { GOOGLE } \\
\text { ACADÊMICO }\end{array}$ & - & 1 & 11 & 14 & - & - \\
\hline GOOGLE & - & - & 2 & 5 & - & - \\
\hline ANPED 2013 & - & - & - & - & - & - \\
\hline $\begin{array}{c}\text { ANPED } \\
\text { REGIONAIS } \\
2014\end{array}$ & - & - & - & 1 & - & - \\
\hline ENDIPE 2014 & - & - & - & - & - & 7 \\
\hline ANPAE 2015 & - & - & - & 2 & - & - \\
\hline II CONBAlf & - & - & - & 17 & - & - \\
\hline ANPED 2015 & - & - & - & 1 & - & - \\
\hline REVISTAS & - & - & - & 7 & 4 & - \\
\hline TOTAL & - & 3 & 12 & 47 & 4 & 7 \\
\hline $\begin{array}{l}\text { TOTAL } \\
\text { GERAL }\end{array}$ & \multicolumn{6}{|l|}{73} \\
\hline
\end{tabular}

Fonte: Base de dados pesquisados em abril/maio de 2015 e atualizados em outubro de 2015.

No que concerne às três dissertações encontradas, apresentamos algumas dimensões observadas: objetivos e problema de pesquisa, campo teórico explorado, metodologia e principais resultados.

A dissertação “A Formação continuada de professores alfabetizadores: do próletramento ao Pnaic" (SALOMÃO, 2014) teve como objeto de estudo as políticas educacionais voltadas para a formação continuada de professores dos anos iniciais do 
Ensino Fundamental. Analisou a implantação e implementação das ações desenvolvidas pelo governo federal no sentido de contribuir para a superação das dificuldades dos professores alfabetizadores no processo de ensino e aprendizagem.

O desenvolvimento dessa pesquisa teve como foco principal a análise do processo de implantação do Pacto Nacional pela Alfabetização na Idade Certa na rede pública de ensino no Município de Ponta Grossa em 2013. A pesquisa apresentou a seguinte problemática: Como se deu o processo de implantação do Pnaic a partir da consolidação do Programa Pró-Letramento? Além da questão levantada, definiu como objetivos específicos: contextualizar a constituição das políticas públicas educacionais para a formação continuada dos professores a partir da década de 1990 no Brasil; identificar os aspectos do Programa Pró-Letramento que foram determinantes para a implantação do Pnaic; identificar a proposta de implantação do Pnaic para a formação dos professores alfabetizadores.

A pesquisa dialogou dialeticamente com os seguintes pensadores e teóricos: Marx, Ciavatta, Crozatto, Bruno, Duarte, Freitas, Frigotto, Gatti, Kuenzer, Saviani e Tardif. O eixo teórico-metodológico se expressa por meio do materialismo histórico e dialético que concebe a realidade a partir da apreensão de suas contradições na sua totalidade. Os procedimentos metodológicos adotados foram pautados na pesquisa teórica bibliográfica das principais produções que abordam a temática estudada; e na pesquisa documental do processo de consolidação do Programa Pró-Letramento no âmbito das políticas educacionais para a formação continuada de professores dos anos iniciais, bem como a implantação do Pacto Nacional pela Alfabetização na Idade Certa.

A referida pesquisa pôde constatar que a constituição das políticas públicas educacionais para a formação continuada de professores a partir da dácada de 1990 no Brasil, passou por momentos importantes em sua contextualização, na redefinição do capitalismo e as implicações que esse processo causou na área educacional, constituindo entre o final do século XX e o início do século XXI, um período de transformações econômicas, políticas e sociais. Na conjuntura social de transformações, o processo educativo passa a ser concebido sob aspectos que enfatizam a busca por uma qualidade no ensino, tomada por programas dentro das políticas educacionais que permeiem por caminhos que visem as reais melhorias.

Nesse sentido, a educação deve ir além de processos limítrofes, que deixem a desejar no aspecto relevante quanto a sua função social ou que regule erroneamente a 
qualidade dos programas educacionais, levando em conta os objetivos que norteiam seus discursos voltados para uma educação de qualidade para todos. E como conclusão final, a pesquisa apresentou limites (vazio teórico, presente nos diferentes níveis e organizações do contexto educativo; a superação do senso comum; a formação inicial insuficiente adquirida nos cursos das instituições de ensino superior com falhas explícitas nos saberes acadêmicos, teóricos e científicos; a fragmentação e descontinuidade de ações nas políticas estatais voltadas às necessidades dos profissionais da educação) e possibilidades (o aprofundamento e atualização dos conhecimentos do professor; o papel de protagonista para o professor nas intenções dos projetos dos programas de formação continuada, fazendo parte de um fazer contínuo ao longo da constituição de sua vida profissional; o apoio financeiro do Governo Federal para o desenvolvimento dos programas de formação continuada do professor; a equidade ao acesso à formação e a articulação entre os domínios teóricos e práticos nas ações educativas) da formação continuada de professores.

A dissertação "Formação continuada de professores: experiências integradoras de políticas educacionais - Pnaic e PROUCA - para alfabetização no Ensino Fundamental de uma escola pública” (TEDESCO, 2015) teve por objetivo investigar de que maneira a Formação Continuada de professores alfabetizadores contribui para reflexão e tomada de atitude para melhoria da prática pedagógica utilizada no ambiente da sala de aula dos anos iniciais do Ensino Fundamental, com orientação da política do Pacto Nacional pela Alfabetização na Idade Certa e em contextos digitais, oportunizados pelo Programa Um Computador por aluno - PROUCA para o uso das tecnologias digitais e como vem interferindo no cotidiano de uma escola de ensino público municipal, da cidade de Fagundes Varela, RS.

A pesquisa apresentou a seguinte problemática: Quais contribuições a formação continuada de professores agrega à metodologia de professores alfabetizadores de anos iniciais do ensino fundamental de escola pública, com orientação da política do Pnaic e em contextos digitais, oportunizados pelo PROUCA? A pesquisa foi subsidiada pelos teóricos: Bakhtin, Bardin, Cagliari, Charlot, Fagundes, Ferreira e Leal, Freire, Gatti, Imbernón, Moll, Moran, Nóvoa, Soares, Tardif, Zabala. A abordagem metodológica para a pesquisa foi de cunho qualitativa, baseada em observações, questionário, análise documental; e de posse dos dados coletados, utilizou-se a análise textual discursiva. 
Através da pesquisa realizada, foi possível perceber o comprometimento e a preocupação dos docentes com o ato de ensinar e aprender de maneira reflexiva, inovadora e qualitativa pela inserção das tecnologias digitais e o novo olhar para a aprendizagem de alunos no ciclo de alfabetização. Assim, os resultados demonstraram-se positivos e satisfatórios na opinião dos professores que efetivamente participaram das formações dos Programas Um Computador por aluno - PROUCA e Pacto Nacional pela Alfabetização na Idade Certa - Pnaic; considerando, assim, os tais programas, como instrumentos que auxiliam no desenvolvimento de competências e potencialidades para qualificar o fazer pedagógico no ciclo de alfabetização de alunos nos anos iniciais do Ensino Fundamental.

E como conclusão final, a pesquisa considerou os programas de formação continuada tanto do Pnaic quanto do PROUCA como instrumentos que auxiliam no desenvolvimento de competências e potencialidades para qualificar o processo de ensinar e aprender no ciclo de alfabetização de alunos nos anos iniciais, com maior qualidade e motivação, avançando em sintonia com a disseminação das TDs.

A dissertação “A Formação continuada do professor alfabetizador nos cadernos do Pnaic" (SOUZA, 2014) teve como objetivo geral analisar os cadernos da formação continuada do professor alfabetizador no Pacto Nacional pela Alfabetização na Idade Certa - Pnaic.

A pesquisa apresentou o seguinte questionamento: Qual a concepção de ensino, de aprendizagem e de desenvolvimento infantil que subjaz nos documentos do Pnaic? Além dos questionamentos apresentados, definiu como objetivos específicos: compreender o Pnaic no contexto social e investigar a concepção de ensino expressa, principalmente, nos cadernos de Alfabetização em Língua Portuguesa da formação do Pnaic, a partir da compreensão de aprendizagem e desenvolvimento infantil.

A pesquisa dialogou dialeticamente com os seguintes pensadores e teóricos: Duarte, Durkheim, Hipólito, Kosik, Leal, Lukács, Marx, Vigotski, Mészáros, Mello, Smolka, Soares, Torriglia. O método que orienta a investigação é o materialismo histórico e dialético, a concepção teórica da ontologia crítica de Lukács e a teoria histórico-cultural que teve como precursor Vigotski. Os procedimentos metodológicos adotados foram pautados na pesquisa teórica bibliográfica das principais produções que abordam a temática estudada; na pesquisa documental dos cadernos do Pnaic e nas teorias de Marx, Lukács e Vigotski. 
A referida pesquisa pôde explicitar que a formação continuada no Pnaic é um desdobramento das políticas de educação e, em seu sentido amplo da formação do ser social na qual a gênese está no trabalho, que no decorrer da história da humanidade e das complexificações do ser social se modifica até chegar à forma abstrata no capital. Assim, a formação expressa no Pnaic surge para responder à problemática da não alfabetização e promover o direito de aprendizagem da criança. Mas, esse problema da realidade educacional existe há muitos anos. Assim percebeu-se que o interesse e a necessidade de propiciar a formação continuada ao professor não tem início com o Pnaic, já existiram outros programas que buscaram socializar o conhecimento metodológico, incentivar a reflexão e valorizar os saberes da prática do professor, reorientar as estratégias de ensino, compartilhar experiências, entre outros aspectos.

E como conclusões finais, a pesquisa identifica que a perspectiva teórica dos cadernos da formação do Pnaic é o "construtivismo" e o "sociointeracionismo", e, a partir destes apontamentos, apresenta algumas contribuições da psicologia soviética acerca do ensino, da aprendizagem e do desenvolvimento.

Diante desse estudo, explicita que a formação propiciada pelo Pnaic - a partir da análise dos cadernos do primeiro ano da formação continuada - que visa formar os professores para garantir os direitos de aprendizagem das crianças, ainda apresenta condições incipientes para fornecer ao professor alfabetizador elementos e condições suficientes para ele realizar a atividade de ensino e para ampliar as possibilidades da aprendizagem da criança o que limita o aprofundamento de conhecimentos e o desenvolvimento humano.

Assim, destacamos que o Pnaic foi abordado nessas três dissertações tendo como foco a sua implantação enquanto política pública, os cadernos de formação utilizados em 2013 e a sua relação com o PROUCA, outra política pública para a alfabetização e formação continuada de professores alfabetizadores.

Pretendemos avançar, privilegiando em nossa pesquisa, o Pnaic enquanto Política Pública de Educação e analisando as concepções de formação continuada presentes no mesmo, possibilitando uma compreensão histórica e crítica sobre a formação de professores alfabetizadores.

Considerando todos os documentos encontrados no Estado do Conhecimento sobre o objeto de pesquisa proposto, podemos agrupá-los segundo as categorias abordadas e metodologia utilizada: 


\section{QUADRO 3 - CATEGORIAS - ESTADO DO CONHECIMENTO}

\begin{tabular}{|c|c|c|c|c|c|c|}
\hline CATEGORIAS & DISSERTAÇÃO & $\begin{array}{c}\text { MONOGRAFIA } \\
\text { TCC }\end{array}$ & ARTIGO & REPORTAGEM & PÔSTER & TOTAL \\
\hline $\begin{array}{c}\text { ALFABETIZAÇÃO } \\
\text { E LETRAMENTO }\end{array}$ & - & 3 & 9 & 1 & 2 & $\begin{array}{c}15 \\
(20,6 \%)\end{array}$ \\
\hline $\begin{array}{c}\text { ENSINO E } \\
\text { APRENDIZAGEM }\end{array}$ & 1 & 2 & 5 & - & - & $\begin{array}{c}8 \\
(10,95 \%)\end{array}$ \\
\hline $\begin{array}{c}\text { FORMAÇÃO } \\
\text { CONTINUADA }\end{array}$ & 1 & - & 9 & - & 3 & $\begin{array}{c}13 \\
(17,8 \%)\end{array}$ \\
\hline $\begin{array}{c}\text { FORMAÇÃO DE } \\
\text { PROFESSORES }\end{array}$ & - & - & 5 & - & - & $\begin{array}{c}5 \\
(6,84 \%)\end{array}$ \\
\hline $\begin{array}{c}\text { PLANEJAMENTO } \\
\text { PEDAGÓGICO }\end{array}$ & - & 1 & 6 & - & - & $\begin{array}{c}7 \\
(9,58 \%)\end{array}$ \\
\hline Pnaic & - & 4 & 6 & 2 & 2 & $\begin{array}{c}14 \\
(19,17 \%)\end{array}$ \\
\hline $\begin{array}{c}\text { POLÍTICAS } \\
\text { EDUCACIONAIS }\end{array}$ & 1 & 2 & 7 & 1 & - & $\begin{array}{c}11 \\
(15,06 \%)\end{array}$ \\
\hline
\end{tabular}

Fonte: Base de dados pesquisados em abril/maio de 2015 e atualizados em outubro de 2015.

A categoria "Alfabetização e letramento", abordada principalmente em nove artigos com relatos de experiências de professores alfabetizadores, traz o foco nas práticas docentes. Esses relatos são de professores que cursando a formação do Pnaic modificaram suas práticas em sala de aula e atingiram resultados exitosos com os seus alunos. Nessa perspectiva de reflexão sobre a prática, os relatos são principalmente a respeito dos diferentes desafios que hoje envolvem o trabalho interdisciplinar particularmente nos anos iniciais, com reflexos nos momentos posteriores da escolaridade. Também há destaque para o material de formação do Pnaic que incentiva o trabalho com projetos interdisciplinares nos anos iniciais.

A três monografias encontradas enfatizam a importância da formação continuada do Pnaic na consolidação do processo de alfabetização das crianças até os oito anos e a ênfase no letramento e não apenas na decodificação da língua materna. A monografia “O Programa Nacional pela Alfabetização na idade certa à luz do atual Estado da Arte sobre alfabetização” (BASSOUTO, 2013) analisa e discute as propostas do Pnaic, tendo como objetivos explicitar o conceito de alfabetização assumido no pacto e conhecer tanto os procedimentos pedagógicos recomendados quanto as estratégias de formação de professores definidas, além dos materiais de ensino utilizados. 
Quanto à monografia "Dissonância entre as ações governamentais (Pnaic e PCNs) Brasileiras em alfabetização e as evidências científicas” (GUISSO, 2013) o propósito desse estudo é compreender o desalinhamento entre as ações governamentais como o Pnaic e os PCN's, e as evidências científicas acerca da alfabetização. O referido estudo aponta que os programas governamentais caminham em sentido contrário ao que é indicado nas evidências científicas para alfabetização, ou seja, a necessidade de adotar um método para alfabetizar.

E a monografia "A Alfabetização do campo e o Pnaic: possibilidades e entraves" (BURITI, 2014) analisou a realidade pedagógica das escolas da Educação do Campo da Rede Municipal de Nova Palmeira/PB. Esse estudo traz um levantamento a respeito de como se deu o processo de alfabetização nas diversas escolas desse município, a partir da formação do Pnaic e do uso de novas metodologias utilizadas pelo programa tendo em vista as dificuldades do professor em sala de aula no campo.

Quanto à categoria "Ensino e aprendizagem", destacamos, além da dissertação "A Formação continuada do professor alfabetizador nos cadernos do Pnaic" (SOUZA, 2014), já analisada anteriormente, que as duas monografias encontradas e os cinco artigos abordaram as contribuições da formação continuada do Pnaic para a prática pedagógica e o processo de ensino e aprendizagem das crianças, principalmente em relação ao uso de materiais didáticos, jogos matemáticos e livros literários. Ainda com o foco na reflexão sobre a prática, valorizam o acompanhamento do processo de ensino/aprendizagem das crianças no ciclo de alfabetização, trazendo uma análise sobre os encontros realizados e a contribuição desses encontros no processo de alfabetização; revelando, assim, o caráter do programa de formação numa abordagem didática e com foco na prática dos professores e formas de organização de ensino

A monografia "O processo de aprendizagem dos alunos nos anos iniciais do Ensino Fundamental na perspectiva do Pnaic" (LIMA, 2014) faz uma reflexão sobre o ensino fundamental na perspectiva do Pnaic e o processo de consolidação da aprendizagem alfabética e letramento propostos pelo pacto. Traz um breve levantamento bibliográfico sobre as políticas públicas para a Educação Básica e suas influências no desenvolvimento educacional de crianças e adolescentes de 4 a 17 anos; bem como uma reflexão do cotidiano escolar da Rede Estadual de Ensino do Município de Princesa Isabel/PB.

Quanto à monografia "Sentidos das práticas pedagógicas com uso de textos em turmas de $1^{\circ}$ ano do Ensino Fundamental" (GARCIAS, 2013) investiga os sentidos que 
o uso de textos adquire nas didáticas em alfabetização em duas turmas de $1^{\circ}$ ano do Ensino Fundamental de uma escola municipal de Porto Alegre. Foram realizadas entrevistas semi-estruturadas com as professoras responsáveis pelas turmas e analisados os cadernos dos alunos. Foi realizado também um paralelo entre os discursos que relacionam alfabetização e textos, vistos em funcionamento nas duas turmas e nos cadernos de formação do Pnaic trabalhados em 2013. Constatou-se que apesar das professoras relatarem o uso de textos nas turmas de $1^{\circ}$ ano, o que mais se verificou foram atividades que exploram as letras do alfabeto.

As categorias "Formação de professores" e "Formação continuada" foram objeto de reflexão no que tange a importância para a profissionalidade docente, mas não foi abordada a formação continuada atrelada à valorização do professor. Quanto à categoria "Formação de professores", elencamos os seguintes aspectos analisados nos cinco artigos: o importante papel que os Orientadores desempenharam nesta rede de formação, suas experiências no cotidiano das escolas e nos momentos formativos junto aos alfabetizadores e as contribuições desta experiência de formação para 0 deslocamento do modelo formativo de racionalidade técnica à valorização dos saberes docentes construídos pelos professores no desenvolver de suas práxis.

A categoria "Formação continuada" abordada pela dissertação "A Formação continuada de professores alfabetizadores: do pró-letramento ao Pnaic" (SALOMÃO, 2014) já analisada anteriormente, também se destaca em nove artigos com relatos de professores alfabetizadores sobre a formação do Pnaic. Os professores consideram relevante a referida formação continuada, pois a partir da reflexividade, tem facilitado as trocas de experiências entre eles, tornando a aula mais atrativa, criativa, fazendo a diferença na sala de aula. A formação continuada se apresenta como uma das alternativas de melhoria da qualidade da educação e o quanto esta necessita ser incentivada pelos gestores, pois os professores precisam de espaços e tempo para estudos, pesquisa, diálogo, reflexões, trocas e, compartilhamentos de ideias e sugestões. Evidencia-se a realidade e o contexto escolar, a prática pedagógica desenvolvida, a qual envolve planejamento, metodologia, recursos humanos, materiais e a avaliação, diagnosticando a aprendizagem do aluno e o seu próprio trabalho, sendo uma maneira de fortalecimento da reflexão pedagógica, da mudança e transformação da atuação profissional do docente do Ensino Fundamental.

A categoria "Planejamento pedagógico" foi abordada em uma monografia e em seis artigos, principalmente pelos relatos de experiência de professores 
alfabetizadores e orientadores de estudo. Essa categoria trouxe elementos importantes para o Ciclo de Alfabetização: a importância do planejamento pedagógico e do espaço de coordenação pedagógica, a figura do coordenador pedagógico na formação do Pnaic e a organização das práticas de ensino com o uso de sequências didáticas e projetos de trabalho.

A monografia "A importância do planejamento de aula" (RÊGO, 2014) resulta de uma pesquisa de campo que analisa a importância dada ao planejamento de aulas por professoras dos anos iniciais de uma escola pública municipal em Campina Grande/PB. São apresentadas concepções teóricas acerca do planejamento de ensino e informações sobre a estrutura do Sistema de Ciclos e do programa de formação do Pnaic. Traz uma análise do discurso de duas professoras e uma supervisora pedagógica quanto suas práticas de ensino e de planejamento; constatando o planejamento como fator essencial para uma aula produtiva. Como conclusão, têm-se a consideração de que há distância entre o discurso e a prática quando se relaciona o dito e o observado durante a pesquisa.

A categoria "Políticas Educacionais" analisa a implantação e o impacto do Pnaic como um dos programas do Governo Federal para a formação continuada de professores alfabetizadores; bem como o envio de recursos pedagógicos, avaliação e mobilização social para a aprendizagem das crianças. Essa categoria teve destaque na dissertação "Formação continuada de professores: experiências integradoras de políticas educacionais - Pnaic e PROUCA - para alfabetização no Ensino Fundamental de uma escola pública" (TEDESCO, 2015), analisada anteriormente, e também em duas monografias e sete artigos.

A monografia "Políticas públicas avaliativas e programa de formação docente: algumas inquietações" (PEREIRA, 2013) investiga os efeitos de duas políticas públicas, uma de avaliação da Educação Básica - Provinha Brasil e outra um programa de formação docente - Pnaic em turmas de alfabetização de uma escola da Rede Municipal de São Leopoldo/RS. O estudo foi realizado a partir de três categorias de análise: o discurso das avaliações externas - concepção teórica e prática das professoras em relação à avaliação da aprendizagem dos alunos; o discurso do programa de formação do Pnaic; e o discurso sobre a não reprovação no Ciclo de alfabetização. Como conclusão do estudo evidenciou-se que os professores têm sido pouco informados sobre as políticas públicas que chegam à escola, considerando as práticas avaliativas em larga escala e os programas de formação docente. 
Quanto à monografia "As dificuldades de consolidar os direitos de aprendizagem no ensino da Língua Portuguesa" (ALVES, 2014) analisa como o Pnaic está possibilitando a consolidação dos direitos de aprendizagem no ensino de Língua Portuguesa nos anos iniciais. Discute sobre a nova tendência de qualificação profissional que considera as práticas sociais como importante elemento no desenvolvimento de práticas educativas significativas. Evidencia variáveis que dificultam a consolidação dos direitos de aprendizagem no fim do Ciclo de alfabetização; e apresenta alguns obstáculos e avanços ocasionados pela política educacional que traz a alfabetização como foco.

Em relação aos artigos que abordaram a categoria "Políticas Educacionais", destacamos algumas reflexões sobre as políticas públicas contemporâneas de formação de professores e o ensino da leitura e da escrita, focalizando o diálogo entre a universidade e a escola pública, compondo uma voz com pesquisadores do campo da formação docente e da alfabetização. Esse diálogo se estabelece entre o elo política pública, formação continuada de professores alfabetizadores e o Pnaic. Temos também uma contextualização da formação do professor alfabetizador e a complexidade do ensino-aprendizagem da leitura e da escrita, reafirmando que os espaços educativos têm papel fundamental no trabalho de desenvolver ações educativas interculturais, viabilizando mudanças que venham ao encontro de uma sociedade multicultural.

Relacionada com todas as demais categorias, temos a categoria "Pnaic", que aborda a apresentação do programa, documentos legais, mas principalmente a importância do programa para a consolidação do processo de alfabetização das crianças até os oito anos. Quanto aos artigos, percebemos reflexões sobre os impactos do Pnaic na formação docente e o reflexo desta no desenvolvimento da aprendizagem dos alunos do $3^{\text {o }}$ ano do Ensino Fundamental. Os professores relataram os avanços no seu crescimento profissional a partir da implantação do Pnaic, destacando as ações governamentais que visam o desenvolvimento da educação brasileira por meio de "vozes" da teoria e da prática.

A monografia "Pnaic: o que dizem as professoras?" (FORAGI, 2013) trabalha com a análise de narrativas de professoras alfabetizadoras de uma escola da rede municipal de Alvorada/RS acerca da implantação das ações do Pnaic permite verificarmos uma boa receptividade em relação ao Pnaic, especialmente direcionada à formação continuada dos professores e aos materiais didáticos e pedagógicos oferecidos pelo programa. Quanto à implementação da proposta frente às condições estruturais das 
escolas públicas, fica evidente nas narrativas a distância entre o planejado nas políticas e o executado. Destaca-se como considerações finais, a necessidade de uma mudança, tanto nas escolas e suas redes, como no sistema público, a fim de suprir demandas que não são apenas escolares, mas também sociais, para que o Pnaic possa atingir seus objetivos pedagógicos no Ciclo de Alfabetização.

Quanto à monografia “As contribuições do Pnaic na aprendizagem da Língua Portuguesa" (JESUS, 2014) temos uma avaliação inicial das contribuições do Pnaic no processo de ensino e aprendizagem da Língua Portuguesa no Bloco Inicial de Alfabetização. Para tanto, buscou-se três objetivos específicos: descrever a proposta do Pnaic, apresentar o ensino em ciclos e a proposta do Bloco Inicial de Alfabetização (BIA) do Distrito Federal e verificar as contribuições do Pnaic na prática pedagógica dos professores alfabetizadores. Os sujeitos da pesquisa foram três professores alfabetizadores de uma escola pública situada em Ceilândia/DF. O instrumento utilizado para coletar os dados foi um questionário com questões subjetivas e a análise de conteúdo. Concluiu-se com esta pesquisa que o Pnaic contribuiu para o processo de ensino e aprendizagem da Língua Portuguesa no BIA, uma vez que incidiu diretamente na prática individual dos professores alfabetizadores, proporcionando novos parâmetros pedagógicos.

A monografia "Professores alfabetizadores no PNAIC: possibilidades e limites" (LIMA, 2014) traz uma breve análise do desenvolvimento das práticas dos professores alfabetizadores que participaram da formação do PNAIC em 2013 no estado da Paraíba; em relação à alfabetização com letramento, seus planejamentos e se os direitos de aprendizagem estão sendo garantidos aos alunos. A pesquisa registra observações na sala de aula, análise dos planejamentos dos professores envolvidos e dados coletados com a aplicação de questionário que discute a alfabetização na perspectiva do letramento e os direitos de aprendizagem nas diversas áreas do conhecimento. Como conclusão a pesquisa destaca o trabalho dos professores na perspectiva do letramento em alguns momentos e a utilização dos recursos didáticos não é citada nos planejamentos pedagógicos.

E a monografia "Alfabetizar até o final do $3^{\circ}$ ano: reflexões sobre a proposta do Pnaic" (SANTOS, 2014) analisa a proposta de alfabetizar em três anos, a partir das orientações do Pnaic. Teve como campo de pesquisa uma escola pública da rede estadual da zona leste de Porto Alegre/RS e como questão principal: Quais as relações entre avanço de ano e alfabetização no Ciclo de alfabetização, a partir das orientações 
do Pacto? Foram analisadas as narrativas de professores e alunos do Ciclo de alfabetização e também o documento de implantação do Pnaic.

Partindo dos objetivos propostos nessa pesquisa, das categorias e metodologia de análise identificados no mapeamento do Estado do Conhecimento, podemos elencar algumas considerações importantes:

- A maioria das publicações encontradas (58 documentos - 78,37\% do total) é de autoria de professores ou pesquisadores das Regiões Sul e Sudeste do país.

- A maioria dos artigos (41 artigos - 87,23\% do total) foi encontrada em Anais de Congressos, Colóquios ou Seminários sobre Educação e Alfabetização; tendo o Google Acadêmico como suporte.

- Os temas mais abordados foram: apresentação do Programa Pnaic, Alfabetização e Letramento, Formação continuada de professores.

- A Formação continuada de professores, na maioria das vezes, é apresentada como necessária e importante para o aperfeiçoamento docente; mas não como elemento de valorização profissional.

- Quanto à metodologia, as pesquisas são de base qualitativa, com relatos de experiências e o uso de entrevistas e questionários. As análises documental e bibliográfica também se destacam.

\section{QUADRO 4 - METODOLOGIA - ESTADO DO CONHECIMENTO}

\begin{tabular}{|c|c|c|c|c|}
\hline MÉTODO/METODOLOGIA & DISSERTAÇÃO & MONOGRAFIA/TCC & ARTIGO & TOTAL \\
\hline $\begin{array}{c}\text { ANÁLISE DOCUMENTAL E } \\
\text { BIBLIOGRÁFICA }\end{array}$ & $\mathbf{1}$ & $\mathbf{6}$ & $\mathbf{1 0}$ & 17 \\
\hline ENTREVISTA/QUESTIONÁRIO & - & $\mathbf{3}$ & 10 & $\mathbf{1 3}$ \\
\hline ESTUDO DE CASO & - & $\mathbf{2}$ & $\mathbf{8}$ & $\mathbf{1 0}$ \\
\hline $\begin{array}{c}\text { MATERIALISMO HISTÓRICO E } \\
\text { DIALÉTICO }\end{array}$ & $\mathbf{2}$ & - & $\mathbf{2}$ & $\mathbf{4}$ \\
\hline PESQUISA-AÇÃO & - & 2 & 1 & 3 \\
\hline RELATO DE EXPERIÊNCIA & - & - & 16 & 16 \\
\hline TOTAL GERAL & 63 & & & \\
\hline
\end{tabular}

Fonte: Base de dados pesquisados em abril/maio de 2015 e atualizados em outubro de 2015.

- Essas informações atreladas à participação como ouvinte no Seminário do PNAIC da Região Centro-Oeste (2015); com a Comunicação Científica no II Congresso Brasileiro de Alfabetização (II CONBAlf - 2015) em Recife, e 
também como ouvinte na $37^{\mathrm{a}}$ Reunião Nacional da ANPED (2015) em Florianópolis/SC nos permitiu fazer generalizações necessárias para o estudo analítico dos documentos do Pnaic. Entretanto, o Pacto ainda está em vigência, e nosso enfoque não será o discurso e a prática efetiva ou a aplicação das propostas da formação continuada desenvolvida no âmbito do Pnaic, e sim, a compreensão das concepções que legitimam e sustentam essa formação docente.

- O nosso objeto de estudo vem sendo abordado, nessas pesquisas e relatos, numa concepção de formação continuada pautada na epistemologia da prática, com ênfase no ensino e aprendizagem das crianças.

Destacamos assim, pelo levantamento no Estado do Conhecimento, que pouco têm sido a ênfase e discussão sobre o professor como trabalhador, atrelado ao seu processo histórico e emancipador de formação e valorização profissional; atravessado nas suas teorias de conhecimento e nas suas práticas pedagógicas pelos conflitos pessoais e profissionais. Pretendemos avançar, privilegiando em nossa pesquisa, um olhar crítico e histórico sobre a formação continuada de professores, buscando superar o antagonismo entre escola e trabalho, numa elaboração de projetos emancipatórios articulados dentro e fora da escola.

A formação continuada do professor alfabetizador é uma categoria singular, dentro de um complexo estruturado, dialeticamente determinado pelas interconexões do geral e do particular. Nossa pesquisa buscou compreender a singularidade da formação do professor alfabetizador no contexto educacional, que se expressa no Pnaic; bem como a particularidade (documentos e cadernos do programa), e as concepções de formação continuada que neles se expressam, e, ademais, algumas relações gerais na conjuntura educacional. Assim, com a investigação das concepções de formação presentes nos documentos oficiais e nos cadernos de formação do professor alfabetizador, buscamos compreender elementos dessa formação que estão na proposta do Pnaic e que almeja formar um perfil de professor em um determinado modo de produção da existência humana. Nesse sentido, no próximo capítulo, analisamos os elementos norteadores das políticas públicas educacionais no Brasil direcionadas para a formação continuada de professores alfabetizadores que se consolidam no contexto do neoliberalismo. 


\section{CAPÍtulo 3 - POLÍticas PÚBliCAS dE FORMAÇÃO CONTINUADA DE PROFESSORES ALFABETIZADORES E O PACTO NACIONAL PELA ALFABETIXAÇÃO NA IDADE CERTA}

Este capítulo analisa os elementos norteadores das políticas públicas educacionais engendradas no Brasil no contexto do neoliberalismo e direcionadas para a formação continuada de professores alfabetizadores e que se consolidam no Pacto Nacional pela Alfabetização na Idade Certa.

A formação continuada de professores, compreendida enquanto política pública de educação, prática e discurso pedagógicos, é uma ação social recente e em ascensão no Brasil. A pesquisa educacional sobre a formação de professores também possibilitou o crescente interesse pelo estudo, reflexão e relação entre a formação continuada, a prática docente e melhoria do ensino, e a constituição da profissão docente.

Segundo Santos (2010), a formação continuada ao constituir-se como uma ferramenta necessária ao processo de profissionalização do professor, é parte de um processo inacabado, de permanente elaboração e reelaboração do trabalho pedagógico. Assim, ela torna-se imperiosa, principalmente quando a ação tem como horizonte a construção de práticas educativas propositivas. Nesse contexto, partimos do entendimento de que a formação continuada é parte constituinte do exercício profissional do professor. Ela emerge como uma necessidade do trabalho docente, por isso ela é concebida como processo permanente, contínuo, que ocorre durante toda a carreira profissional, desde a formação inicial até a formação continuada (desenvolvimento profissional). Enfim, a formação continuada é um processo histórico e inacabado, vinculado às questões da profissão docente e da educação como prática social.

A formação continuada de professores passou por várias transformações desde o final da década de 1970 e início da década de 1980 no Brasil, muitas impulsionadas pelas transformações em relação à concepção, função da escola e poder do Estado. Conforme nos alerta Freitas (1999), as reformas educacionais em nosso país, desde a década de 1970, apresentam como objetivo a adequação do sistema educacional ao processo de reestruturação do papel do Estado e sua relação com a reestruturação do Capital. A formação de professores, nesse contexto, ora é abordada como elemento impulsionador e realizador dessas reformas, ora como elemento que cria condições para 
a transformação da própria escola, da educação e da sociedade. O conteúdo de cada política específica carrega normas e orientações para efetivar comportamentos sociais necessários para a sustentação do modo de produção, na atualidade, o capitalismo.

Segundo Santos (2014) a política de formação se define a partir de um conjunto de medidas administrativas, técnicas, financeiras e pedagógicas que também traduz a intencionalidade dessa ação. Isso significa que devemos, então, buscar conhecer as condições oferecidas para o desenvolvimento da formação continuada, discutindo o conteúdo dessas políticas, na medida em que ela imprime uma determinada concepção de formação de professor, que se corporifica nas práticas formativas e no trabalho docente.

A compreensão das políticas públicas de educação direcionadas para a educação básica, e especialmente para a alfabetização, por meio de programas e estratégias articuladas pelo Governo Federal, os Estados e municípios; tem se pautado em discursos produzidos sobre a melhoria da qualidade de ensino, na defesa pela qualificação profissional docente e numa perspectiva de formação continuada configurada na reflexão sobre a prática. Essas contradições relacionam-se dialeticamente com as necessidades e interesses do Estado e da sociedade, e a educação tornou-se uma política estratégica necessária ao desenvolvimento do capital e à conformação social.

Marx (2008) afirma que toda realidade é complexa, que não existe realidade simples, é o princípio da totalidade. Toda realidade é complexa, porque o real é concreto, síntese de múltiplas determinações. Isso contribui muito para entender as políticas educacionais, pois com base nesses princípios é possível fazer uma análise no âmbito da sociedade brasileira, do contexto histórico, social, econômico e cultural.

O entendimento da formação continuada como política e prática, integrante da realidade histórica, social e cultural, nos remete ao caráter da historicidade e da totalidade quanto à implantação do Pacto Nacional pela Alfabetização na Idade Certa. Essa proposta de formação expressa finalidades e princípios construídos por instituições e sujeitos sociais motivados por interesses políticos e pedagógicos pertencentes ao presente e ao passado de nosso contexto socioeducacional quanto ao processo de alfabetização.

Segundo Mortatti (2011) a alfabetização escolar é um processo complexo e multifacetado que envolve ações especificamente humanas e, portanto, políticas, caracterizando-se como dever do Estado e direito constitucional do cidadão. Desde o 
final do século XIX pode-se constatar, em determinados momentos, a centralidade atribuída, no âmbito do que hoje determinamos políticas públicas, a um ou a alguns aspectos específicos da alfabetização.

A partir do final da década de 1970, a luta pela democratização da educação centrou-se na defesa do direito à escolarização para todos, da universalização do ensino e da maior participação da comunidade na gestão da escola. Nesse contexto da década de 1970, o Estado apossa-se do processo de formação docente, utilizando normas, regulamentos, pareceres e programas para garantir a ordem e os direitos dos cidadãos; mas também fortalecendo o poder e domínio da sociedade. Numa perspectiva da epistemologia da racionalidade técnica, a formação do professor assume um papel mediador na perpetuação e transmissão da ideologia do Estado; ou seja, o professor é formado para ser um técnico, numa lógica do saber fazer teórico sem refletir sobre a ação, desconsiderando o poder no espaço pedagógico e a intencionalidade do ato educativo.

Especialmente no início da década de 1980, com as mudanças tecnológicas na relação de produção e a pressão social por melhora na qualidade da educação, essas constatações indicaram a necessidade de pensar em políticas públicas; manifestando dialeticamente as relações entre teoria e ação do Estado no que se refere ao atendimento às necessidades básicas sociais, como direito do cidadão e direito dos profissionais da educação à formação continuada. Como marco desse movimento contraditório das políticas públicas e de reforma do ensino, a Declaração de Jomtien (1990) assinada na Conferência Mundial de Educação para Todos ${ }^{1}$, no Ano Internacional da Alfabetização, e com a Declaração de Salamanca (1994) temos definiçõos e novas abordagens sobre as necessidades básicas de aprendizagem, tendo em vista estabelecer compromissos mundiais para garantir a todas as pessoas os conhecimentos básicos necessários a uma vida digna, visando uma sociedade mais humana e mais justa; além de termos uma visão renovada da política educativa e da cooperação internacional no campo da educação e melhoria da qualidade do ensino.

${ }^{1}$ A Conferência Mundial de Educação para Todos foi o marco a partir do qual os noves países com maior taxa de analfabetismo do mundo (Bangladesh, Brasil, China, Egito, Índia, Indonésia, México, Nigéria e Paquistão), conhecidos como "E-9", foram levados a desencadear ações para a consolidação dos princípios acordados na Declaração de Jomtiem. Seus governos comprometeram-se a impulsionar políticas educativas articuladas a partir do Fórum Consultivo Internacional para a "Educação para Todos", coordenado pela UNESCO, que, ao longo da década de 1990, realizou reuniões regionais e globais de natureza avaliativa (SHIROMA, 2007, p. 48). 
No Brasil, o Ministério da Educação divulgou o Plano Decenal de Educação Para Todos para o período de 1993 a 2003, elaborado em cumprimento às resoluções da Conferência de Jomtien; no qual o governo brasileiro assume compromisso de garantir a satisfação das necessidades básicas de educação, cujo objetivo mais amplo é assegurar, até o ano de 2003, a crianças, jovens e adultos, conteúdos mínimos de aprendizagem que atendam a necessidades elementares da vida contemporânea. A partir da Lei de Diretrizes e Bases da Educação Nacional - LDBEN nº 9.394/96, são implementadas as reformas curriculares e instituído um sistema nacional de avaliação e gestão da escola, no qual o papel do professor passa a não se restringir mais ao trabalho em sala de aula; mas ampliado também para a participação na gestão da escola, elaboração de projetos educacionais, discussões e decisões acerca do currículo e avaliação institucional.

O Plano Nacional de Educação (PNE), em 2001, elaborado em parceria com a Unesco e em favor da Educação para todos, estabeleceu como meta da educação nacional a extensão do ensino fundamental obrigatório de nove anos de duração; além de ter como objetivos principais a elevação do nível de escolaridade da população e melhoria da qualidade da educação. O PNE (2001) também elenca como uma das metas para valorização do magistério da Educação Básica a ampliação da formação continuada, com foco na qualificação e atualização dos professores.

Em 6 de fevereiro de 2006, a Lei no 11.274, institui o Ensino Fundamental de nove anos de duração com a inclusão das crianças de seis anos de idade. A ampliação do ensino fundamental e suas diretrizes e metas demandaram maior atenção ao processo de alfabetização e a instituição do Ciclo de alfabetização (6 à 8 anos), o que demarcou não só um período, mas uma idade para ingresso e para consolidação da alfabetização das crianças até os oito anos de idade.

Também com a declaração pela Organização das Nações Unidas (ONU) de que o período de 2003 a 2012 seria designado à década da alfabetização, fortalecem os movimentos políticos e da academia na perspectiva de busca de inovações da alfabetização no Brasil, nos programas de formação docente e de avaliação em larga escala. O Plano de Desenvolvimento da Educação (PDE), apresentado à sociedade em abril de 2007, afirma a necessidade e a importância das políticas de avaliação como ações de controle de qualidade e de investimento na educação. Adicionalmente, foram criados o Índice de Desenvolvimento da Educação Básica (IDEB) e a assistência técnica da União aos municípios e estados brasileiros para promoverem reflexões sobre necessidades, aspirações e prioridades educacionais a serem alcançadas. Com essas 
mudanças, a formação continuada se tornou importante instrumento para propiciar a adequação às reformas curriculares e dar subsídios às novas demandas exigidas pelos professores.

Com os documentos expedidos pelos organismos internacionais como o Banco Mundial, a Organização das Nações Unidas para a Educação, a Ciência e a Cultura (UNESCO) e a Organização para Cooperação e Desenvolvimento Econômico (OCDE) que priorizam, em seus contextos, a educação para a Educação Básica; os governos passaram a concentrar-se no processo de reestruturação da formação de professores e na universalização e expansão do Ensino Fundamental. A formação docente assume a concepção de pedagogia de competências e habilidades, com ênfase na formação prática/validação das experiências, na formação continuada e na educação à distância. Esse movimento de reestruturação sinaliza elementos contraditórios na formação docente. Ao mesmo tempo em que temos o investimento e a prioridade para a formação de professores, a subordinação da educação ao racionalismo utilitarista e ao senso comum como lógica orientadora das ações pedagógicas, reduz o sentido do conhecimento ao pragmatismo.

O cenário nacional da formação do professor recebe não só influências externas dos organismos internacionais, como as internas advindas do próprio sistema educacional. Entre essas, destacam-se as deficiências pedagógicas, o aviltamento salarial, a precariedade das condições de trabalho, as jornadas excessivas de trabalho e a inexistência de planos de carreira. Entretanto, a formação sofre, também, o impacto da tendência histórica de estímulo à rede privada e restrição ao setor público, no que se refere particularmente à expansão do número de instituições privadas de Educação Superior; à subordinação das políticas educacionais às recomendações de organismos internacionais diversos e à criação dos Institutos Superiores de Educação.

Na lógica do capital, a educação está a serviço do mercado, seja para atender às necessidades imediatas do sistema produtivo, no tocante à qualificação de mão de obra especializada; seja como contraponto à ameaça de fratura social gerada pelas políticas estruturais implementadas, cujas consequências colocam em risco a integridade da sociedade. A necessidade de regulação adquire caráter central no campo da educação. Para satisfazer essa necessidade, o Estado se apropria da avaliação como instrumento de controle, regulação e fiscalização, afastando-a de uma função pedagógica e formativa que a caracteriza. A prevalência da lógica das competências e das habilidades reinstitui 
o tecnicismo como modelo de formação, agora revestidos dos princípios de eficiência e produtividade.

Considerando o exposto, entendemos que as políticas públicas são ações que nascem do contexto social, mas passam pela esfera estatal. Constituem, pois, em um processo revelador da interação de um conjunto muito rico de determinações econômicas, políticas e culturais, e seu debate encerra fortes tensões entre visões sociais diferentes. Contraditoriamente, o trabalho do professor e, consequentemente, sua formação estão estritamente relacionados aos modelos organizacionais do trabalho produtivo e à regulamentação dos comportamentos e atitudes que sustentam a racionalização das sociedades modernas pelo Estado.

Nesse sentido, com a implantação das políticas públicas neoliberais no cenário da formação docente no Brasil, principalmente a partir de 1990, a tônica da formação continuada dos professores assumiu novos conceitos, ideias e valores; incluindo a responsabilização individual pela própria formação, a autoavaliação, a polivalência, flexibilidade e reflexão sobre suas práticas e sobre as práticas escolares, tudo como conjunto de habilidades e competências necessárias ao trabalho docente. Os professores investigadores buscam entender os problemas do cotidiano escolar como base para a criação de alternativas transformadoras, fundamentadas na abordagem do professor reflexivo/pesquisador.

Partindo da problematização de suas práticas, os professores tentam propor alternativas conjuntas e desenvolverem projetos implantados, e discutidos coletivamente, transformando o ensino em reflexão sobre a prática. Essa metodologia configura a ação docente como objeto sistemático da análise dos professores, pois as práticas pedagógicas são continuamente observadas, pensadas, avaliadas e transformadas. Stenhouse (1986), Garcia (1992), Perrenoud (1993), Nóvoa (1997), Gimeno Sacristán (1996), Giroux (1997), Zeichner (1998), Alarcão (1998), Schön (2000) e Tardif (2002) têm sido os grandes inspiradores dos trabalhos de formação continuada do professor reflexivo.

Segundo Curado Silva (2001) o paradigma que orienta a concepção de formação de professores inicial e continuada a partir da década de 1990, e direciona a articulação teoria e prática é a epistemologia da prática. Essa perspectiva busca romper com a proposta de racionalidade técnica presente até então nos cursos de formação de professores, cuja ênfase está na aplicação da teoria à prática. 
A atividade prática, portanto, passou a ser o principal eixo da formação docente, tendo como lócus central a experiência, o exercício prático. Podemos inferir que este formato se alinha com os objetivos estabelecidos pelas políticas públicas neoliberais, intensificando uma visão pragmatista da formação deste profissional. É necessário, pois, refletir acerca desta cultura constituída em torno do professor reflexivo/pesquisador no processo de formação docente, na qual cria uma falsa promessa de transformação ao propagar que o professor, refletindo sobre sua prática, melhorará suas ações pedagógicas e, consequentemente, a qualidade do ensino.

Para Schön (2000) o ensino prático reflexivo para desenvolver habilidades profissionais pautado nas ideias de conhecer-na-ação, reflexão-na-ação e reflexão sobre a reflexão-na-ação; permite que os docentes se preparem para as demandas da prática. Zeichner (1998) defende o papel do professor pesquisador, argumentando sobre a necessidade da pesquisa educacional que proporcione maior interação entre as vozes dos professores e as dos acadêmicos; ampliando a visão puramente instrumental dessa pesquisa.

Tardif (2002) ressalta a necessidade de repensar a formação continuada levando em conta os saberes dos professores e as realidades específicas de seu trabalho cotidiano, possibilitando renovar nossa concepção a respeito de suas identidades, contribuições e papéis profissionais.

Segundo Oliveira (2012) o caráter de formação compensatória, destinado a preencher lacunas da formação inicial, aliado à necessidade de garantir a implementação das reformas educativas dos anos de 1990, estimulou fortemente o desenvolvimento de programas de formação continuada em serviço. A formação passa a desenvolver-se preferencialmente no âmbito da instituição escolar, na qual o profissional exerce suas atividades, envolvendo todo o corpo docente e, por vezes, membros da equipe e da comunidade escolar. Assim, sob a coordenação do Ministério da Educação, foram intensificadas as ações de formação das secretarias municipais e estaduais, onde diversos programas, os chamados "programas oficiais" foram implantados dentro das modalidades presenciais, semipresenciais e a distância.

No início do século XXI, observamos a construção de um novo perfil do professor adequado aos novos tempos, envolvendo desde a formação inicial e continuada aos salários e condições de trabalho e a necessidade de profissionalização docente. A partir da criação da Rede Nacional de Formação Continuada de Professores da Educação Básica (RNFC) em 2004 pelo Ministério da Educação (MEC), com a 
finalidade de contribuir com a qualidade do ensino e para o desenvolvimento e oferta de programas de formação continuada; percebemos a elaboração de materiais didáticos destinados aos professores em serviço, além de ações de formação em parceria com as Instituições de Ensino Superior (IES), nas quais se inserem os Centros de Pesquisa e Desenvolvimento da Educação, e os Estados e Municípios.

A respeito desses programas de formação continuada estabelecidos pela Rede Nacional de Formação Continuada de Professores da Educação Básica destacamos:

- Pró-Formação (1997-2004): direcionado à formação continuada de professores de $1^{\mathrm{a}}$ a $4^{\mathrm{a}}$ séries do Ensino Fundamental e orientado pela Secretaria de Educação a Distância (SEED). Marca o início das políticas públicas para formação docente com ênfase na alfabetização e prática pedagógica.

- Programa de Formação de Professores Alfabetizadores (PROFA-2001): formação continuada desenvolvida com professores alfabetizadores e orientada pela Secretaria de Educação a Distância (SEED). O objetivo principal foi desenvolver as competências profissionais dos professores que ensinam a ler e a escrever (crianças, jovens e adultos), tendo a justificativa de oferecer aos professores alfabetizadores os conhecimentos didáticos de alfabetização. $\mathrm{O}$ curso teve a duração de 160 horas (75\% do tempo é ocupado em formação de grupos e $25 \%$ em trabalho pessoal), durante quarenta semanas, e recurso didático composto por materiais escritos e vídeos. Teve como foco a proposta de superar a retenção escolar, apoiando-se na descrição psicogenética de que o processo de alfabetização é o mesmo, independentemente das diferentes classes sociais e das propostas de ensino do professor; e aponta como diferença as experiências prévias dos alunos com práticas sociais de leitura e escrita. O curso foi ofertado aos professores alfabetizadores que atuavam na $1^{\mathrm{a}}$ série do ensino fundamental, com o foco no início do processo de alfabetização.

- Pró-Infantil (2005): dirigido à formação continuada dos professores de Educação Infantil em nível médio, por meio de tutorias e supervisionado pelas Instituições de Ensino Superior parceiras.

- Pró-Letramento (2008-2012): desenvolvido em parceria com os sistemas de ensino e com as Universidades da Rede de Formação Continuada e 
Desenvolvimento da Educação, constituindo-se como um programa de formação continuada de professores dos Anos Iniciais do Ensino Fundamental centrado em alfabetização e matemática. Surge com o intuito de melhorar a qualidade da aprendizagem de leitura, escrita e matemática nos anos iniciais do Ensino Fundamental. Conforme guia do referido programa (BRASIL, 2007), o Estado tem como objetivos oferecer suporte à prática pedagógica dos professores; propor condições para a construção do conhecimento na formação docente e nos processos de ensino e aprendizagem; desenvolver e desencadear ações que incentivem a formação continuada. O programa estipula a organização, características, bolsa, avaliação e relatórios. Fundamenta-se nos conceitos de língua e ensino de língua; alfabetização; letramento; e ensino da língua escrita. Adota como pressupostos as seguintes concepções: a centralidade da língua é a interação verbal, letramento pautado nos gêneros textuais. O curso foi ofertado aos professores nos anos iniciais do ensino fundamental, com o foco no processo de consolidação de alfabetização.

Esses programas de formação continuada de professores, fomentados por essas parcerias com os sistemas de ensino, na maioria das vezes, tem resultado em ações descontinuadas das práticas, contrapondo à ideia da formação como um processo que se realiza num movimento dialético, de idas e vindas, em que o professor se constrói e reconstrói como pessoa e como profissional, a partir de uma dinâmica que tem a ver com um processo de "vir a ser" do sujeito e não a partir de um tipo ideal de professor, que normalmente é projetado separadamente das condições objetivas de realização do trabalho docente. Quando se está diante de políticas que parecem estar sempre recomeçando do "zero", estar-se-ia negando um movimento que, aliás, é intrínseco à própria educação. Saviani (2005) afirma que a descontinuidade na formação humana consiste numa contradição, ao negar a especificidade da educação como trabalho que tenha continuidade, que dure o tempo suficiente para atingir os objetivos educacionais.

Assim, sobre o movimento da crise econômica internacional de 2008 passou-se a exigir dos governos nacionais o cumprimento de metas de crescimento econômico, a expansão de mercados e a formação de profissionais com domínio em múltiplas tecnologias. Seguindo essa lógica, a educação pública passou a ser vista como espaço de crescimento para os negócios lucrativos e rentáveis. Os governos e empresários do mercado educacional estabeleceram as metas e os indicadores a serem alcançados pelas 
instituições escolares. Com isso, a formação de professores privilegia a eficiência, a prática, as metas a serem alcançadas e resultados significativos de aprendizagem.

Desse modo, o Pacto Nacional pela Alfabetização na Idade Certa (Pnaic) foi implantado em julho de 2012 com o objetivo principal de garantir o direito à alfabetização plena, a todas as crianças até oito anos de idade, ao final do $3^{\circ}$ ano do Ensino Fundamental; reafirmando o que propõe o plano de metas Compromisso Todos pela Educação, previsto no Decreto 6.094/2007, especificamente no tocante ao inciso II do art. $2^{\circ}$; ou seja, responsabilidade dos entes governamentais de "alfabetizar as crianças até, no máximo, os oito anos de idade, aferindo os resultados por exame periódico específico". E a Meta 05 do projeto de lei que trata sobre o Plano Nacional de Educação também reforça este aspecto:

Alfabetizar todas as crianças, no máximo, até o final do terceiro ano do Ensino Fundamental (PNE, 2014, p. 58).

Ao aderir ao Pacto, os entes governamentais comprometem-se a: alfabetizar todas as crianças em língua portuguesa e em matemática; realizar avaliações anuais universais, aplicadas pelo Instituto Nacional de Estudos e Pesquisas Educacionais Anísio Teixeira (INEP), junto aos concluintes do $3^{\circ}$ ano do ensino fundamental e no caso dos estados, apoiar os municípios que tenham aderido às Ações do Pacto, para sua efetiva implantação. A Portaria do MEC esclarece no artigo $5^{\circ}$, que as ações do Pnaic têm por objetivos:

I - garantir que todos os estudantes dos sistemas públicos de ensino estejam alfabetizados, em Língua Portuguesa e em Matemática, até o final do $3^{\circ}$ ano do ensino fundamental; II - reduzir a distorção idade-série na Educação Básica; III melhorar o Índice de Desenvolvimento da Educação Básica (IDEB); IV - contribuir para o aperfeiçoamento da formação dos professores alfabetizadores; $\mathrm{V}$ - construir propostas para a definição dos direitos de aprendizagem e desenvolvimento das crianças nos três primeiros anos do ensino fundamental. (PORTARIA n ${ }^{\circ} 867$, Art $5^{\circ}$, 2012).

As Ações do Pacto são um conjunto integrado de programas, materiais e referências curriculares e pedagógicas disponibilizados pelo Ministério da Educação e 
que pretendem dar suporte para a alfabetização e o letramento, tendo como eixo principal a formação continuada dos professores alfabetizadores. Analisando o Manual do Pacto Nacional pela Alfabetização na Idade Certa - Livreto 2013, destacamos que estas ações apoiam-se em quatro eixos de atuação:

I - Formação Continuada de Professores Alfabetizadores: Curso presencial para os professores alfabetizadores, com carga horária de 120 horas em 2013, 160 horas em 2014, 80 horas em 2015 e 80 horas em 2016; com base no programa Pró-Letramento, cuja metodologia propõe estudos e atividades práticas. Os encontros com os professores alfabetizadores são conduzidos por orientadores de estudo. Os orientadores de estudo são professores das redes, que fizeram um curso específico - com 200 horas de duração em 2013 e 200 horas em 2014, e 100 horas em 2015 e 100 horas em 2016 - ministrado por universidades públicas. É recomendável que os orientadores de estudo sejam selecionados entre a equipe de tutores formados pelo Pró-Letramento no município ou estado (BRASIL, 2012).

Importante destacar que o programa de formação de professores alfabetizadores, incluído nas Ações do Pacto, tem como referência os livros e materiais didáticos e pedagógicos fornecidos pelo Ministério da Educação. Segundo a Portaria $\mathrm{n}^{\circ}$ 867/MEC-2012, a formação continuada dos professores alfabetizadores precisa garantir, dentre outros aspectos, as ferramentas para alfabetizar com planejamento. A alfabetização ocorre no dia a dia e deve ser voltada para cada um dos alunos. Portanto, o curso tem enfoque sobre os planos de aula, as sequências didáticas e a avaliação diagnóstica, onde se faz um mapeamento das habilidades e competências de cada aluno, para traçar estratégias que permitam ao aluno aprender efetivamente. A formação precisa garantir ainda o aprofundamento dos conhecimentos sobre alfabetização, interdisciplinaridade e inclusão como princípio fundamental do processo educativo.

O curso é estruturado na tentativa de melhoria da prática docente. Por isso, contém algumas atividades permanentes, como a retomada do encontro anterior, com socialização das atividades realizadas, de acordo com as propostas planejadas para o trabalho em sala de aula, análise de atividades destinadas à alfabetização e planejamento de atividades a serem realizadas nas aulas seguintes ao encontro. O conteúdo do curso foi elaborado com base na experiência de formação do Pró-Letramento. Neste sentido, um conjunto de universidades públicas que participam desse programa é responsável 
pelo conteúdo da formação dos professores alfabetizadores. O curso de formação aborda também a inclusão de crianças com deficiência.

Os formadores dos professores alfabetizadores são os orientadores de estudo, escolhidos entre os próprios professores pertencentes ao quadro das redes públicas de ensino e com experiência como tutores do Pró-Letramento. Quanto às atribuições, o orientador de estudo deve ministrar o curso de formação, acompanhar a prática pedagógica dos professores alfabetizadores cursistas, avaliar a frequência e a participação no curso de formação, manter registro de atividades dos professores alfabetizadores cursistas junto aos educandos e apresentar relatórios pedagógicos e gerenciais das atividades referentes à formação dos professores alfabetizadores cursistas.

Em 2013, o curso de formação teve ênfase na Alfabetização e Letramento em Língua Portuguesa, com debates e estudos acerca dos Direitos de aprendizagem das crianças e avaliação no Ciclo de Alfabetização; Sistema de Escrita Alfabética; Eixos do ensino da língua; Organização e planejamento do trabalho pedagógico; Educação especial e questões sobre a Educação no campo.

Em 2014 a ênfase foi na Alfabetização Matemática, com estudos e troca de experiências sobre os seguintes temas: Organização e planejamento do trabalho pedagógico; Quantificação, registros e agrupamentos; Construção do sistema de numeração decimal; Operações na resolução de problemas; Geometria; Grandezas e medidas; Educação estatística; Saberes matemáticos e outros campos do saber; Educação matemática inclusiva; Educação matemática no campo e Jogos na alfabetização matemática.

Em 2015/2016 o curso de formação abordou todos os componentes curriculares de maneira interdisciplinar e também a importância da Gestão Escolar no Ciclo de Alfabetização. Os temas estabelecidos para estudo e discussão em 2015 foram: Currículo na perspectiva da inclusão e da diversidade - as Diretrizes Curriculares Nacionais da Educação Básica e o Ciclo de Alfabetização; A criança no Ciclo de Alfabetização e Interdisciplinaridade no Ciclo de Alfabetização. Para o ano de 2016 a formação teve como foco: A organização do trabalho escolar e os recursos didáticos na alfabetização; A oralidade, a leitura e a escrita no Ciclo de Alfabetização; Ciências da Natureza no Ciclo de Alfabetização. 
II - Materiais Didáticos e Pedagógicos: Este eixo é formado por conjuntos de materiais específicos para alfabetização, tais como: livros didáticos (entregues pelo Programa Nacional do Livro didático - PNLD) e respectivos manuais do professor; obras pedagógicas complementares aos livros didáticos e acervos de dicionários de língua portuguesa (também distribuídos pelo PNLD); jogos pedagógicos de apoio à alfabetização; obras de referência, de literatura e de pesquisa (entregues pelo Programa Nacional Biblioteca da Escola - PNBE) e obras de apoio pedagógico aos professores (BRASIL, 2012).

Além de novos conteúdos para alfabetização, muda também a quantidade de materiais entregues às escolas, cujos acervos são calculados por número de turmas de alfabetização e não por escola, possibilitando aos docentes e alunos explorar melhor os conteúdos.

O MEC encaminhou para as escolas incluídas nas Ações do Pacto, durante 2013 e 2014, os seguintes materiais:

a - Cadernos de apoio para os professores matriculados no curso de formação.

b - Livros didáticos de $1^{\circ}, 2^{\circ}$ e $3^{\circ}$ anos do ensino fundamental e os respectivos manuais do professor, distribuídos pelo Programa Nacional do Livro Didático (PNLD) para cada turma de alfabetização.

c - Obras pedagógicas complementares aos livros didáticos, distribuídos pelo Programa Nacional do Livro Didático - Obras Complementares para cada turma de alfabetização.

d - Jogos pedagógicos para apoio à alfabetização para cada turma de alfabetização.

e - Obras de referência, de literatura e de pesquisa distribuídas pelo Programa Nacional Biblioteca da Escola (PNBE) para cada turma de alfabetização.

f - Obras de apoio pedagógico aos professores, distribuídas por meio do PNBE para os professores alfabetizadores.

g - Tecnologias educacionais de apoio à alfabetização para as escolas.

III - Avaliações: Este eixo reúne três componentes principais. Primeiramente, as avaliações processuais, debatidas durante o curso de formação, que podem ser desenvolvidas e realizadas continuamente pelo professor junto aos educandos. A segunda mudança refere-se à disponibilização de um sistema informatizado no qual os professores deverão inserir os resultados da Provinha Brasil de cada criança, no início e no final do $2^{\circ}$ ano e que permitirá aos docentes e gestores analisar de forma agregada 
essas informações e adotar eventuais ajustes. A terceira medida é a aplicação, junto aos alunos concluintes do $3^{\circ}$ ano, da Avaliação Nacional da Alfabetização (ANA) pelo INEP, visando aferir o nível de alfabetização alcançado ao final do ciclo. Também neste caso, o custo dos sistemas e das avaliações externas será assumido pelo Ministério da Educação (BRASIL, 2012).

A primeira aplicação dessa avaliação foi em novembro de 2013 e os resultados preliminares foram divulgados em agosto de 2014, mas ainda sem matriz de referência para análise. A segunda aplicação ocorreu em novembro de 2014 e em 2016 o MEC divulgou a matriz de referência para aplicação da terceira etapa da ANA que ocorreu entre os dia 14 a 25 de novembro de 2016.

IV - Gestão, Controle Social e Mobilização: O arranjo institucional proposto para gerir o Pacto é formado por quatro instâncias: a) um Comitê Gestor Nacional; b) uma coordenação institucional em cada estado, composta por diversas entidades, com atribuições estratégicas e de mobilização em torno dos objetivos do Pacto; c) Coordenação Estadual, responsável pela implantação e monitoramento das ações em sua rede e pelo apoio à implantação nos municípios; e d) Coordenação Municipal, responsável pela implantação e monitoramento das ações na sua rede. Ainda neste eixo, destaca-se a importância do sistema de monitoramento que vem sendo disponibilizado pelo MEC, destinado a apoiar as redes e a assegurar a implantação de diferentes etapas do Pacto. Por fim, ressalta-se também a ênfase do MEC no fortalecimento dos conselhos de educação, dos conselhos escolares e de outras instâncias comprometidas com a educação de qualidade nos estados e municípios.

Todo esse sistema político de decretos, leis, portarias e acordos estabelecido pelo Governo através do Pacto Nacional pela Alfabetização na Idade Certa retrata o ideário neoliberal de parceria entre o Estado e a sociedade. O Estado neoliberal apossa-se do processo de formação de professores, tendo em vista a importância política e a influência do mesmo no contexto social do país. Com o objetivo de assegurar a hegemonia de suas concepções o Estado neoliberal propõe uma formação de professores numa perspectiva neotecnicista, tendo a técnica como definidora das relações sociais e educacionais; desconsiderando a autonomia docente no espaço pedagógico, a intencionalidade do ato educativo e a valorização do trabalho docente como princípio ontológico do homem. 
Para Melo (2004) termos como empregabilidade, competitividade, eficiência, eficácia, presentes na direção de nossas políticas educacionais desde os anos 1980, são mais facilmente associados ao neoliberalismo, assim como a crítica a projetos de atendimento assistencial, e políticas de privatização da educação.

Denominado de Terceira Via, esse projeto, direcionado principalmente às forças sociais de centro-esquerda que chegaram ao poder nos últimos anos do século $\mathrm{XX}$; possui uma concepção de natureza técnica, de atender às necessidades humanas. Nega, assim, a centralidade da categoria "trabalho" para a constituição humana ao reduzi-la à ideia de ocupação ou emprego. Temos como principal eixo a educação para a eqüidade social. Tal mudança de paradigma implica transformações substantivas na organização e na gestão da educação pública. Passa a ser um imperativo dos sistemas escolares formar os indivíduos para a empregabilidade, já que a educação geral é tomada como requisito indispensável ao emprego formal e regulamentado, ao mesmo tempo em que deveria desempenhar papel preponderante na condução de políticas sociais de cunho compensatório, que visem à contenção da pobreza.

A nova gestão pública apresenta-se, geralmente, como politicamente neutra. No campo da educação, desde os sistemas centrais até à escola, passam a ser adotadas diretrizes gerenciais na condução dos serviços educacionais. A gestão baseada nos resultados e nos indicadores de desempenho constitui-se em fator crucial da modernização da gestão educativa. Esse novo desenho de gestão das políticas públicas educacionais traz a regulação e a ação pública como elementos nos programas, estabelecendo a formulação dos mesmos no nível central e a descentralização na implantação ou execução local. Nessa perspectiva, percebemos um processo que exige a disposição da sociedade civil para trabalhar em parceria com o Estado, o incentivo para a resolução de seus próprios problemas, e até mesmo, um pacto com o objetivo principal de garantir o direito de alfabetização plena a todas as crianças até oito anos de idade, estabelecendo para isso, uma idade certa para consolidação do processo de alfabetização.

O Plano de Metas - Compromisso Todos pela Educação (Decreto $n^{\circ}$ 6.094/2007) que visa estabelecer a responsabilização de todos com a melhoria da qualidade do ensino; propõe o cumprimento de 28 diretrizes, das quais 27 focalizam aspectos qualitativos das ações educacionais e uma que visa ampliar o acesso e permanência das pessoas com necessidades educacionais especiais nas classes do ensino regular. Com isso, especificamente no tocante ao inciso II do art. $2^{\text {o; }}$ ou seja, 
responsabilidade dos entes governamentais de "alfabetizar as crianças até, no máximo, os oito anos de idade, aferindo os resultados por exame periódico específico"; percebemos as estratégias e concepções estabelecidas pelo Pnaic para que a criança esteja alfabetizada ao final do ciclo de alfabetização do ensino fundamental, com oito anos de idade, nos termos da Lei $n^{\circ}$ 11.274/2006 (que ampliou o ensino fundamental obrigatório para nove anos, com início aos 6 anos de idade); reforçando assim o slogan do Pacto quanto à idade certa para o processo de alfabetização. As crianças têm direito de se apropriar do sistema alfabético de escrita e, de forma autônoma, de participar de situações de leitura e escrita. Aquelas que não sabem ler e escrever textos com autonomia têm dificuldades para dar continuidade ao processo de escolarização e de participar de várias situações extraescolares.

Assim, a partir de uma análise da realidade brasileira no final do século XX e início do século XXI, é possível verificar que as relações sociais capitalistas foram mantidas, e até mesmo se intensificaram; e que consolidaram uma nova pedagogia da hegemonia política e social, com reforço para o cumprimento dos direitos do cidadão e crescimento globalizado. Essa nova pedagogia da hegemonia materializou-se com ações efetivas na aparelhagem do Estado, configurando uma nova dimensão educativa do Estado capitalista. Sua principal característica é assegurar que o exercício da dominação de classe seja viabilizado por meio de processos educativos positivos. Surge, assim, a figura da sociedade civil e de cada cidadão como responsáveis pela mudança da política e pela definição de formas alternativas de ação social.

Organismos internacionais como o Banco Mundial (BM), o Banco Interamericano de Desenvolvimento (BIRD), a Organização Internacional do Trabalho (OIT) e a Organização das Nações Unidas para a Educação, a Ciência e a Cultura (Unesco), entre outros, realizaram estudos e pesquisas e fizeram diagnósticos, previsões e propostas de reorganização da educação básica e da formação de professores nos países em desenvolvimento, entre eles o Brasil, que aderiu prontamente às propostas.

A formação continuada centrou-se na reflexão dos professores sobre suas práticas e sobre as práticas escolares, tanto do ponto de vista epistemológico quanto político; numa concepção de formação em que a capacitação deverá se realizar, preferencialmente em serviço, com o mínimo de intervenções externas. Assim, a formação passa a desenvolver-se preferencialmente no âmbito da instituição escolar, na qual o profissional exerce suas atividades, envolvendo todo o corpo docente e, por vezes, membros da equipe e da comunidade escolar. 
Neste sentido é que Curado Silva (2008), ao reconhecer esta proposta de formar o prático reflexivo nos documentos legais que embasam a formação docente no Brasil, alerta "sobre o cuidado necessário ao assumir este ideário, principalmente para a profissionalização docente, uma vez que se coloca a ênfase no sucesso ou no fracasso na responsabilização do professor. Entendemos que este praticismo acaba por esvaziar a função do professor formador que, nesta ótica, teria como tarefa mediar, orientar ou apenas facilitar o conhecimento. No processo de formação, o professor não só modifica sua prática, mas recupera seu status profissional e político quando revê e fundamenta a sua própria qualificação e, em um contexto coletivo, toma decisões sobre sua prática pedagógica.

Entendemos que o princípio epistemológico de valorização da prática e dos saberes precisa ser enfrentado e discutido numa perspectiva mais ampla de educação e não apenas como forma de atender a mudanças imediatas no ensino. Porém, se a formação se mantém afastada da situação de trabalho, das condições pedagógicas da escola e do contexto histórico e cultural do professor, não temos uma formação docente transformadora; mas sim, uma formação que reproduz um sistema de ações que objetiva a resolução de problemas imediatos da escola, almejando sempre a hegemonia e o bem estar político e social.

Nesse movimento dialético e buscando compreender a formação continuada de professores alfabetizadores, enquanto política pública de educação, prática e discurso pedagógicos e processo de constituição da profissão docente; realizamos no próximo capítulo uma análise documental dos documentos oficiais e Cadernos de Formação do Pnaic, na condição de identificar e analisar as concepções que legitimam e sustentam essa política educacional. 


\section{CAPÍtUlO 4 - O PACTO NACIONAL PELA ALFABETIZAÇÃO NA IDADE CERTA: ANALISANDO AS CONCEPÇÕES DE FORMAÇÃO CONTINUADA}

Este capítulo objetiva analisar as concepções de formação continuada desenvolvida no âmbito do Pacto Nacional pela Alfabetização na Idade Certa por meio da análise documental de suas bases legais e dos Cadernos de Formação.

Analisando o Caderno de Apresentação referente ao material da Formação do Pnaic em 2013, destacamos que essa formação continuada de professores alfabetizadores e orientadores de estudos apresenta encaminhamentos metodológicos de discussão sobre a alfabetização, na perspectiva do letramento ${ }^{2}$, no que tange o ensino de Língua materna e da Matemática. Assim, os princípios da formação continuada que orientam as ações do Pnaic são:

1 - A prática da reflexividade: pautada na ação prática/teoria/prática, operacionalizada na análise de práticas de salas de aulas, aliadas a reflexão teórica e reelaboração das práticas.

2 - A socialização: operacionalizada na criação e fortalecimento de grupos de estudo durante as formações que, espera-se, transcenda o momento presencial, diminuindo o isolamento profissional, intrínseco à profissão de professor.

3 - O engajamento: privilegiar o gosto em continuar a aprender é uma das metas primordiais da formação continuada e certamente faz parte da melhoria de atuação em qualquer profissão.

4 - A colaboração: para além da socialização, trata-se de um elemento fundamental no processo de formação. Por meio da colaboração, busca-se a formação de uma rede que visa ao aprendizado coletivo, por meio do qual, os professores

\footnotetext{
${ }^{2}$ Segundo Magda Soares, o foco das práticas de alfabetização na perspectiva do letramento deve ser na compreensão dos significados, utilizando para isso a literatura, os gêneros textuais, ou seja, as habilidades de ler e escrever devem ser ensinadas em contexto e como apoio ao desafio maior de "letramento", ou seja, desenvolvimento de habilidades de uso da leitura e da escrita nas práticas sociais que envolvem a língua escrita, e de atitudes positivas em relação a essas práticas (SOARES, 2003, p. 18).
} 
exercitem a participação, $\mathrm{o}$ respeito, a propriação e $\mathrm{o}$ pertencimento.

\section{5 - A constituição da identidade profissional:} efetivada em momentos de reflexão sobre as memórias do professor enquanto sujeito de um processo mais amplo, procurando auxiliá-lo a perceber-se em constante processo de formação.

O professor alfabetizador é inserido numa política pública de formação continuada, tendo em vista a necessidade de todas as crianças estarem alfabetizadas até os oito anos de idade, ao final do Ciclo de Alfabetização; e que a reflexão sobre sua prática, aliada à troca de experiências poderá ser a solução para seus problemas em sala de aula. Essa ideia pode contribuir para a precarização ${ }^{3}$ do trabalho docente, pois enfatiza a questão da reflexão presa à ação profissional entendida simplesmente como a competência do saber fazer cotidiano, apenas numa perspectiva de auto-reflexão sobre o fazer do professor.

Há uma expectativa de que essa política de formação continuada esteja pautada na concepção da epistemologia da prática. Portanto, se faz necessário, por meio da análise documental dos Cadernos de Formação, identificarmos e analisarmos as concepções que norteiam a formação continuada do Pacto Nacional pela Alfabetização na Idade Certa.

Estabelecemos desse modo, nossos eixos de análise documental: I) Papel da formação continuada, II) Função/Papel do professor, III) Modelo estruturante do Pnaic, IV) Concepções de alfabetização; a partir dos quais analisaremos os pré-indicadores e indicadores retratados nos documentos estudados, considerando os temas e elementos abordados, a materialidade do objeto de análise e as categorias que emergem do mesmo. Esses eixos de análise relacionam-se às categorias centrais: I) Concepções de formação

\footnotetext{
3 O fato é que o trabalho pedagógico foi reestruturado, dando lugar a uma nova organização escolar, e tais transformações, sem as adequações necessárias, parecem implicar processos de precarização do trabalho docente. Podemos considerar que assim como o trabalho em geral, também o trabalho docente tem sofrido relativa precarização nos aspectos concernentes às relações de emprego. $\mathrm{O}$ aumento dos contratos temporários nas redes públicas de ensino, chegando, em alguns estados, a número correspondente ao de trabalhadores efetivos, o arrocho salarial, o respeito a um piso salarial nacional, a inadequação ou mesmo ausência, em alguns casos, de planos de cargos e salários, a perda de garantias trabalhistas e previdenciárias oriunda dos rocessos de reforma do Aparelho de Estado têm tornado cada vez mais agudo o quadro de instabilidade e precariedade do emprego no magistério público (OLIVEIRA, 2004, p. 1140).
} 
continuada docente (epistemologia da racionalidade técnica, epistemologia da prática e epistemologia da práxis); II) Relação teoria e prática; III) Estrutura da formação.

Segundo Kosik (1986), o fundamento de todo conhecimento é a cisão do todo. Porém, o avanço em direção à apreensão da totalidade só se efetivará quando esses eixos e categorias de análise documental forem integrados novamente ao todo, no movimento histórico de seu processo de constituição. O processo de análise, dessa forma, continua com a construção dos pré-indicadores e indicadores, que consiste em proceder a um novo movimento de articulação. Evidencia-se, desse modo, que os indicadores só adquirem algum significado se inseridos e articulados na totalidade das categorias de análise e posteriormente nas categorias que emergem do objeto.

Segundo McNally (1999) a língua não é uma prisão, encerrando-se nela qualquer possibilidade de ação, numa perspectiva idealista; mas há uma inexorável relação entre língua, vida, história e sociedade dado que a primeira é uma das esferas na qual se vive a experiência social, portanto, é o próprio material de que é constituída a consciência humana. Quando analisamos documentos de uma política pública educacional, todos os elementos são importantes no âmbito de um projeto de produção do conhecimento, cuja finalidade seja a de compreender objetivamente o mundo e sobre ele agir conscientemente. Assim, os indicadores abstraídos da concretude dos documentos estudados configuram-se como arena de conflito social, de luta e de circunstâncias históricas vividas pelos professores.

Gramsci (1966) afirma que toda linguagem contém os elementos de uma concepção de mundo e de uma cultura e por isso mesmo expressa a maior ou menor complexidade da concepção de mundo de um sujeito histórico. Assim a história se constrói por relações sociais concretas, como, capital e trabalho, trabalho e formação, trabalho docente e formação continuada, políticas públicas e educação; num desdobramento contraditório constante e de apreensão da consciência historicamente produzida.

Shiroma, Campos e Garcia (2005), assinalam que palavras “importam” e explicam o processo histórico, além de auxiliar na compreensão da produção de diretrizes políticas para a educação.

Trabalhar com documentos supõe, portanto, considerá-los resultados de práticas sociais e expressão da consciência humana possível em um dado momento histórico. Compreendê-los pode significar avançar na direção da apropriação, segundo 
Gramsci (1966), da consciência daquilo que somos realmente, consciência concebida como produto do processo histórico até hoje desenvolvido do qual é preciso fazer o "inventário" (SHIROMA, CAMPOS e GARCIA, 2005, p. 428).

Em busca dessa consciência concebida como produto do processo histórico de formação dos professores alfabetizadores e com o objetivo de analisar as concepções de formação continuada presentes na proposta do Pnaic, articulamos e sistematizamos eixos, pré-indicadores e indicadores que se expressam nos documentos legais e de formação dessa política pública de formação docente. Segundo Thompson (1981) a racionalidade presente na documentação não é dada a priori, ao contrário, tal racionalidade é construída como conhecimento que ordena os elementos oferecidos pelas evidências empíricas. Documentos oferecem pistas, sinais, vestígios e significados históricos.

Assim, partimos dos conceitos inseridos no contexto que lhe atribuem significado, entendendo como contexto desde os documentos até as condições históricosociais que os constituem; objetivando um processo construtivo-interpretativo que parte do concreto para o abstrato. Portanto, os eixos de análise documental estabelecem essa relação com o concreto retratado nos documentos que detêm a objetividade que sua condição de evidência histórica lhes atribui. E é nessa relação com a empiria, num processo de interrogação e de desconstrução dos documentos, que os eixos de análise se evidenciam e dialogam com os pré-indicadores. Os pré-indicadores são, portanto, trechos extraídos dos documentos oficiais e dos cadernos de formação do Pnaic compostos por indicadores articulados que carregam e expressam a totalidade do objeto, constituindo posteriormente as suas categorias.

\section{1 - Eixo: Papel/Função da formação continuada}

Quanto ao eixo Papel/Função da formação continuada e seus préindicadores destacamos algumas relações entre o modo de pensar a formação e o trabalho docente, os espaços e os tempos de formação e os espaços e tempos do exercício do trabalho, e entre as experiências de formação e as experiências de trabalho. Nessa perspectiva, os sistemas de formação disponibilizam um conjunto de experiências que se estruturam em programas de formação continuada pensados, sobretudo, como 
organização de conteúdos, de competências necessárias para o bom desempenho da prática docente e de qualidade dos seus instrumentos de trabalho.

\begin{abstract}
A formação continuada como política nacional é entendida como componente essencial da profissionalização docente, devendo integrar-se ao cotidiano da escola, e pautar-se no respeito e na valorização dos diferentes saberes e na experiência docente. Logo, a formação continuada se constitui no conjunto das atividades de formação desenvolvidas ao longo de toda a carreira docente, com vistas à melhoria da qualidade do ensino e ao aperfeiçoamento da prática docente (DOCUMENTO ORIENTADOR DO Pnaic, 2014, P. 1-2)
\end{abstract}

Isso se evidencia nos indicadores a identidade do "ser professor" (individual e/ou coletiva), a reflexividade: identidade do "eu" profissional e do coletivo profissional enquanto categoria docente, a formação continuada como rede de experiências para melhoria de atuação na profissão, planejamento pedagógico reflexivo: educador como sujeito de sua prática educativa, a formação continuada e valorização profissional, a formação continuada e instrumentalização pedagógica. Esses indicadores apontam que as políticas e práticas de formação continuada vêm-se configurando como movimento contraditório, pois ao mesmo tempo em que se atribui à formação continuada uma função de construção da identidade profissional, do professor como protagonista de sua formação e prática pedagógica; contraditoriamente se reforçam a necessidade de melhoria da aprendizagem e o papel do professor nesse amplo processo.

Imbuídos desse objetivo de melhoria da aprendizagem da escola pública, convidamos para uma reflexão, tomando como eixo central o professor como protagonista da sua formação continuada. Ao considerar a formação continuada como atividade essencial ao trabalho docente, busca-se oferecer suporte à prática pedagógica, principalmente ao professor alfabetizador, a partir de situações que incentivem a problematização, a reflexão e a teorização, e que promovam a construção do conhecimento, como processo contínuo de formação profissional (CADERNO DE APRESENTAÇÃO Pnaic 2015, p. 13).

Segundo Santos (2014) as concepções e práticas de formação continuada são estruturadas, organizadas e produzidas considerando-se uma perspectiva de formação docente que enseja a reflexão sobre a prática pedagógica. Reforça-se, nesse contexto, a ideia de relação entre formação continuada, mudança na prática docente e melhoria do 
ensino. Para Freitas (2003) os modelos de formação continuada pautados na avaliação e certificação do professor se constituem mecanismo de classificação e não valorização profissional, cultuando a competição e o esforço individual de cada professor como promotores da qualidade na educação. Todos esses aspectos convergem para a compreensão de que os professores são responsáveis pelo seu desenvolvimento profissional, assim como se afastam da ideia da formação continuada como direito e como processo coletivo e solidário.

\section{2 - Eixo: Função/Papel do professor}

Quando analisamos os pré-indicadores do eixo Função/Papel do professor percebemos a ênfase nos documentos que o professor deve formar para a cidadania e saber o que ensinar e como ensinar; que o professor deve saber avaliar, investigar e ter clareza das suas intencionalidades pedagógicas, que o professor deve planejar suas ações, mediar aprendizagem do aluno e transmitir a ele os conhecimentos necessários; que o professor deve refletir sobre sua prática e replanejar sua prática pedagógica, que o professor deve perceber-se como agente transformador da educação e que o professor deve buscar metodologicamente a melhoria do processo de ensino e de aprendizagem.

O professor deve utilizar instrumentos variados que permitam analisar a progressão dos estudantes e suas relações com as estratégias didáticas adotadas. Nesse processo, é importante estar atento que o planejamento requer que o professor defina os objetivos, ou seja, tenha clareza do que se pretende dos alunos com relação à aprendizagem.

Diante disso, uma ação didática consistente pressupõe necessariamente uma atividade diagnóstica para que o professor possa conhecer melhor os estudantes e reorganizar seu planejamento em função de suas necessidades (CADERNO DE APRESENTAÇÃO Pnaic 2013, p. 25).

Assim, o professor precisa estar atento à avaliação dos estudantes, para conduzir estratégias didáticas que favoreçam esse desenvolvimento integral, sem perder de vista que existem conhecimentos e habilidades que precisam ser dominados pelos estudantes e que é papel da escola garantir que sejam aprendidos/desenvolvidos (CADERNO DE APRESENTAÇÃO Pnaic 2013, p. 25).

Também cabe ao professor estar atento à diversidade de sala de aula, aos diferentes tempos de aprendizagem, buscando atender às necessidades dos alunos, com estratégias de ensino acessíveis a qualquer estudante. $O$ próprio professor é responsável pela avaliação das crianças (CADERNO DE APRESENTAÇÃO Pnaic 2013, p. 26). 
Esses indicadores evidenciam a vinculação entre a educação e o mundo do trabalho e da produção. O papel do professor é redimensionado, deve ser competente, repensar suas práticas para poder responder às novas exigências pedagógicas, que também se vinculam às novas demandas de qualificação profissional.

A prática pedagógica é permeada por diversos fatores que devem ser levados em conta no ato reflexivo, entre eles a necessidade de considerar a heterogeneidade da sala de aula e os níveis de aprendizagem dos alunos, o que exige diferenciadas atividades pedagógicas e que o professor mobilize seus conhecimentos para poder compreendê-los e, assim, tome decisões que atendam a essas necessidades. Esse movimento de analisar, refletir e tomar decisões exige e desafia o professor a repensar a sua prática pedagógica. $O$ repensar sobre a prática leva, a nós professores, a reconfigurações da própria prática pedagógica e coloca no centro das discussões o papel do professor como protagonista do seu desenvolvimento profissional, ou seja, da sua profissionalidade. Isso nos faz questionar como o professor, principalmente o alfabetizador, pode aprender continuamente por meio da reflexão sobre a sua prática pedagógica (CADERNO DE APRESENTAÇÃO Pnaic 2015, p. 14).

No que tange a qualidade do ensino, o pensamento neoliberal pressupõe um modelo de formação de um profissional de "amplo perfil”, versátil, capaz de tomar decisões, refletir sobre sua prática e imbuído do compromisso de uma educação para o exercício da cidadania numa perspectiva de hegemonia e equidade social.

$O$ professor alfabetizador tem a função de auxiliar na formação para o bom exercício da cidadania. Para exercer sua função de forma plena é preciso ter clareza do que ensina e como ensina. Para isso, não basta ser um reprodutor de métodos que objetivem apenas o domínio de um código linguístico. É preciso ter clareza sobre qual concepção de alfabetização está subjacente à sua prática (CADERNO DE APRESENTAÇÃO Pnaic 2013, P. 22).

Essa realidade complexa exige dos professores um perfil que solucione e resolva os impasses do cotidiano escolar, tomando como modelo de identidade um professor comprometido com a transformação da realidade social. É a partir das experiências vivenciadas constantemente em sua prática pedagógica, e da mobilização de conhecimentos, que o professor constrói sua identidade (CADERNO DE APRESENTAÇÃo Pnaic 2015, P. 19). 


\section{3 - Eixo: Modelo estruturante do Pnaic}

O eixo Modelo estruturante do PNAIC estabelece como indicadores uma formação continuada presencial pautada numa metodologia de estudos e foco nas atividades práticas do professor, formação continuada organizada em formato de rede multiplicadora e estrutura hierárquica, formação continuada e cadernos de estudo: material didático reflexivo e temático, formação continuada para os professores alfabetizadores e a alfabetização das crianças até os oito anos de idade e seus direitos de aprendizagem, formação continuada e o pagamento de bolsas de estudo para os professores alfabetizadores e os orientadores de estudo.

Quanto ao primeiro indicador, compreendermos que a formação no âmbito deste programa é focada na prática do professor, de modo que as singularidades do trabalho pedagógico são objeto de reflexão. Refletir, estruturar e melhorar a ação docente é, portanto, o principal objetivo da formação. A mobilização dos saberes docentes é, também, outro ponto central no debate dessa formação continuada.

Segundo a Medida Provisória ${ }^{\circ}$ 586, de 8 de novembro de 2012:

Art. $2^{\circ}$ - A Formação Continuada de Professores Alfabetizadores utilizará material próprio a ser fornecido pelo MEC a todos os orientadores de estudo e professores alfabetizadores cursistas e será ofertada de forma presencial, com duração de: I - duzentas horas anuais, incluindo atividades extra-classe, para os orientadores de estudo; e II - cento e vinte horas anuais, incluindo atividades extraclasse, para os professores alfabetizadores.

Formação continuada presencial para professores alfabetizadores e seus orientadores de estudo, ampliando as discussões sobre a alfabetização na perspectiva do letramento no que tange a matemática. Em outras palavras, que conceitos e habilidades matemáticas são necessários para que a criança possa ser considerada alfabetizada dentro dessa perspectiva. Além disso, tem como objetivo apresentar encaminhamentos metodológicos que possibilitem o desenvolvimento destes direitos de aprendizagem dentro do ciclo de alfabetização (CADERNO DE APRESENTAÇÃO Pnaic 2014, p. 9).

O Programa Pacto Nacional pela Alfabetização na Idade Certa tem sido desenvolvido por meio de ações que estimulam a ação reflexiva do professor sobre o tempo e o espaço escolares. Cinco princípios centrais orientam a concepção dos Cadernos de Formação: Perspectiva de um currículo inclusivo, que defende os Direitos de Aprendizagem de todas as crianças, fortalecendo as identidades sociais e individuais; Integração entre os componentes curriculares; Foco central na organização do trabalho pedagógico; Seleção e discussão de temáticas fundantes em cada área de conhecimento; Ênfase na alfabetização e letramento das crianças (CADERNO DE APRESENTAÇÃO Pnaic 2015, 15). 
Quanto ao indicador de ser uma formação continuada organizada em formato de rede multiplicadora e estrutura hierárquica, execução das ações de formação continuada de professores respalda-se na política nacional de formação de profissionais do magistério da educação básica, instituída pelo decreto $\mathrm{n}^{\circ}$ 6.755, de 29 de janeiro de 2009. Logo, a formação continuada se constitui no conjunto dos programas de formação de professores desenvolvidos desde junho de 2003 pela Rede Nacional de Formação Continuada de Professores da Educação Básica (RNFC), com vistas à melhoria da qualidade do ensino, em consequência da qualificação permanente do trabalho docente, além de uma articulação entre as instituições formadoras e socialização das experiências produzidas sobre educação com os professores da Educação Básica.

O processo de formação continuada é coordenado por 38 IES públicas, sendo 31 federais e 7 estaduais (BRASIL, Portaria no 867/2012).

Quanto às particularidades do curso de formação, deverão ser levadas em conta as especificidades de cada etapa de escolaridade que compõe o ciclo de alfabetização, centrando as discussões nos modos de abordagem dos temas, na escolha dos materiais didáticos e nos planejamentos de aulas voltados a cada ano. (CADERNO DE APRESENTAÇÃ̃ Pnaic 2013, p. 26).

No âmbito de cada secretaria de educação será selecionado um coordenador das ações do Pacto, seguindo os critérios: ser professor efetivo da secretaria de educação; ter experiência na coordenação de projetos ou programas federais; possuir amplo conhecimento da rede de escolas, dos gestores escolares e dos docentes envolvidos no ciclo de alfabetização; ter capacidade de se comunicar com os atores locais envolvidos no ciclo de alfabetização e de mobilizá-los; ter familiaridade com os meios de comunicação virtuais (CADERNO DE APRESENTAÇÃO Pnaic, 2013, p. 27).

Os formadores da formação dos orientadores de estudo são responsáveis por ministrar a formação e acompanhar o trabalho dos orientadores na formação dos professores, por meio da orientação em atividades de planejamento da formação e avaliação. Cada formador deve atender, no máximo, 25 orientadores de estudo (MANUAL LIVRETO Pnaic, 2013, p. 26).

No que tange ao indicador de formação continuada e cadernos de estudo: material didático reflexivo e temático, evidenciamos que os objetivos e materiais da formação continuada voltam-se principalmente às necessidades dos sistemas de ensino, às estratégias que permitam mudanças mais imediatas no âmbito da prática docente e da melhoria da aprendizagem. 
Oito cadernos para cada curso - $1^{\circ}, 2^{\circ}, 3^{\circ}$ anos e Educação do Campo - (32 cadernos ao todo), com textos teóricos sobre os temas da formação, relatos de professores, sugestões de atividades, dentre outros (CADERNO DE APRESENTAÇÃ̃O Pnaic, 2013, p. 23).

Portal com informações sobre a formação e materiais para os professores alfabetizadores; livros adotados nas escolas dos professores alfabetizadores; obras literárias das bibliotecas das escolas, adquiridos por meio do Programa Nacional de Biblioteca da Escola; jogos adquiridos pelo Ministério da Educação e distribuídos às escolas e Cadernos de avaliação da Provinha Brasil, produzidos e distribuídos pelo INEP (CADERNO DE APRESENTAÇÃO Pnaic, 2013, p. 23)

O indicador formação continuada para os professores alfabetizadores e a alfabetização das crianças até os oito anos de idade e o direito à educação, se constituem em todos os cadernos de formação do Pnaic. Além de abranger os processos de ensinoaprendizagem da alfabetização na perspectiva do letramento, a alfabetização passa a designar ainda processos ligados aos usos sociais da leitura e da escrita, tendo em vista o atendimento aos direitos de aprendizagem das crianças no Ciclo de Alfabetização.

A formação do professor alfabetizador apresenta-se como responsabilidade social. Busca contribuir para o aperfeiçoamento da formação dos professores alfabetizadores; e discutir sobre as estratégias para a melhoria da educação, habilidades e capacidades a serem contempladas nas propostas curriculares e também sobre quais são as principais aprendizagens esperadas para cada ano escolar. Executar projetos de formação de leitores, ampliando o domínio dos conhecimentos necessários ao desenvolvimento do ensino da leitura e da escrita na perspectiva do letramento (CADERNO DE APRESENTAÇÃO Pnaic 2013, p. 17).

Ao final do ciclo de alfabetização, a criança tem o direito de saber ler e escrever, com domínio do sistema alfabético de escrita, textos para atender a diferentes propósitos. Considerando a complexidade de tais aprendizagens, concebe-se que o tempo de 600 dias letivos é um período necessário para que seja assegurado a cada criança o direito às aprendizagens básicas da apropriação da leitura e da escrita; necessário, também, à consolidação de saberes essenciais dessa apropriação, ao desenvolvimento das diversas expressões e ao aprendizado de outros saberes fundamentais das áreas e componentes curriculares, obrigatórios, estabelecidos nas Diretrizes Curriculares Nacionais para o Ensino Fundamental de Nove Anos (MANUAL LIVRETO Pnaic 2013, p. 17). 
Esses indicadores sustentam as diretrizes políticas assumidas pelo MEC a partir de 2003, em especial dos aspectos relacionados à Rede Nacional de Formação Continuada de Professores da Educação Básica (RNFC). A Portaria n ${ }^{\circ} 1403$ de 09 de junho de 2003 institui o Sistema Nacional de Certificação e Formação Continuada de Professores que compreende o pagamento de bolsa de incentivo à formação continuada e a implantação da RNFC. Esses elementos reafirmam o indicador de formação continuada e o pagamento de bolsas de estudo para os professores alfabetizadores e os orientadores de estudo do Pnaic.

Segundo a Resolução $\mathbf{n}^{\circ} 4$ de 27 de fevereiro de 2013 que estabelece orientações e diretrizes para o pagamento de bolsas de estudo e pesquisa para a formação continuada de professores alfabetizadores, no âmbito do pacto nacional pela alfabetização na idade certa, é estabelecido que:

Art. $5^{\circ}$ - A Formação Continuada de Professores Alfabetizadores contempla o pagamento de bolsas para as seguintes funções: I - coordenador-geral da IES; II - coordenador-adjunto junto à IES; III - supervisor junto à IES; IV formador junto à IES; V - coordenador das ações do Pacto nos estados, Distrito Federal e municípios; VI - orientador de estudo; e VII - professor alfabetizador.

Art. $6^{0}$ - São agentes da formação continuada de professores alfabetizadores: i secretaria de educação básica do ministério da educação (SEB/MEC); ii Fundo Nacional de Desenvolvimento da Educação (FNDE); iii - Instituições de Ensino Superior (IES); iv - Secretarias de Educação dos Estados, do Distrito Federal e dos municípios. Nesta mesma resolução, são detalhadas as atribuições e responsabilidades dos agentes da formação continuada de professores alfabetizadores.

Art. 18 - A bolsa será concedida pela SEB/MEC e paga pelo FNDE diretamente aos beneficiários, por meio de crédito em conta-benefício específica, mediante aceitação, pelo bolsista, de Termo de Compromisso (Anexo I) em que constem, dentre outros:

I - autorização para o FNDE, conforme o caso, bloquear valores creditados na conta benefício, mediante solicitação direta ao Banco do Brasil S/A, ou proceder ao desconto nos pagamentos subseqüentes, nas seguintes situações: a) ocorrência de depósitos indevidos; b) determinação do Poder Judiciário ou requisição do Ministério Público; e c) constatação de irregularidades na comprovação da freqüência do bolsista; d) constatação de incorreções nas informações cadastrais do bolsista.

II - obrigação do bolsista de, inexistindo saldo suficiente na conta-benefício e não havendo pagamentos futuros a serem efetuados, restituir ao FNDE, no prazo de 15 (quinze) dias a contar da data do recebimento da notificação, os valores creditados indevidamente ou objeto de irregularidade constatada, na forma prevista no art. 25 desta resolução.

Parágrafo único. A bolsa será paga durante todo o período efetivo de realização da Formação, podendo ser paga por tempo inferior ou mesmo sofrer interrupção, desde que justificada.

Art. 19 - A título de bolsa, de acordo com a responsabilidade assumida por cada beneficiário e com o efetivo cumprimento de suas atribuições, o FNDE pagará mensalmente, durante o período da Formação, o valor estipulado no art. 17, por meio de depósito em conta-benefício específica para esse fim, aberta pelo FNDE em agência do Banco do Brasil S/A, indicada pelo bolsista entre aquelas cadastradas no SGB. 
$\S 2^{\circ} \mathrm{O}$ recebimento de qualquer um dos tipos de bolsa de que trata este artigo vinculará o participante à Formação Continuada de Professores Alfabetizadores.

Segundo a Medida Provisória no 586, de 8 de novembro de 2012:

Art. $3^{\circ}$ - A Formação Continuada de Professores Alfabetizadores, ofertada por instituições de ensino superior (IES) formadoras definidas pelo MEC, será ministrada aos orientadores de estudo que, por sua vez, serão os responsáveis pela formação dos professores alfabetizadores.

$\S 1^{\circ}$ Os recursos para realização da Formação Continuada de Professores Alfabetizadores serão alocados diretamente no orçamento das instituições de ensino superior (IES) ou transferidos por meio de descentralizações, convênios ou outras formas de transferência.

$\S 2^{\circ}$ As IES utilizarão os recursos referidos no parágrafo anterior exclusivamente para a implementação das atividades necessárias à Formação Continuada de Professores Alfabetizadores, podendo aplicá-los, dentre outras, nas seguintes finalidades: aquisição de equipamentos; material de consumo; contratação de serviços; pagamento de diárias e passagens; e apoio técnico. §3o A equipe docente das IES formadoras, os coordenadores das ações do Pacto nos estados, Distrito Federal e municípios, os orientadores de estudo e os professores alfabetizadores, enquanto atuarem na Formação Continuada de Professores Alfabetizadores poderão receber bolsas, na forma e valores definidos em resolução específica do Fundo Nacional de Desenvolvimento da Educação - FNDE.

\section{4 - Eixo: Concepções de alfabetização}

O eixo Concepções de alfabetização define a alfabetização viva, ativa, social, num contexto linguístico e matemático; alfabetização e letramento multidisciplinar e cultural no Ciclo de Alfabetização; alfabetização e formação teórico-metodológica dos professores alfabetizadores.

A perspectiva assumida, portanto, é de uma alfabetização viva, em que as crianças se apropriem da leitura e da escrita de modo ativo, agindo socialmente: ler e escrever para interlocutores que assumem diferentes papéis sociais, e não apenas para o professor, para atender a diferentes propósitos, contextualmente situados. O objetivo é que as crianças aprendam a ler e escrever, mas também aprendam por meio da leitura e da escrita (CADERNO 1, UNIDADE 1, Pnaic 2013, p. 22).

Esses indicadores estabelecem a compreensão da alfabetização, não com um

fim em si mesma (visando apenas o domínio de habilidades técnicas, codificação/decodificação dos signos alfabéticos); mas, sobretudo, como direito e 
possibilidade de cidadãos alimentarem suas vivências, com o domínio da leitura e melhor compreensão do mundo em que vivem.

É ressaltado que ser alfabetizado é muito mais do que dominar apenas os rudimentos da leitura e escrita, mesmo sendo capaz de ler e escrever todas as palavras. A pessoa alfabetizada é aquela que é capaz de ler e escrever em diferentes situações sociais, de tal forma que isso lhe permita inserir-se e participar ativamente de um mundo letrado, enfrentando os desafios e demandas sociais. Para que isso aconteça não basta apenas o domínio dos conhecimentos relacionados à linguagem, é necessário também um amplo domínio do campo relacionado à matemática, no qual os números e o sistema de numeração decimal são fundamentais, mas não são os únicos aspectos que devem ser abordados na escola (CADERNO 1 Pnaic 2014, p. 21).

No universo da alfabetização, entendemos a importância de ressaltar o processo da criança se alfabetizar cultural e esteticamente, de modo que o mundo do sensível esteja lado a lado com a razão, criando significado próprio à aprendizagem (CADERNO 1 Pnaic 2015, p. 18).

Estar alfabetizado significa ser capaz de interagir por meio de textos escritos em diferentes situações. Significa ler e produzir textos para atender a diferentes propósitos. A criança alfabetizada compreende o sistema alfabético de escrita, sendo capaz de ler e escrever, com autonomia, textos de circulação social que tratem de temáticas familiares ao aprendiz.

O ciclo de alfabetização deve garantir a inserção da criança na cultura escolar, bem como a aprendizagem da leitura e da escrita e a ampliação de seu universo de referências culturais, nas diferentes áreas do conhecimento (MANUAL LIVRETO Pnaic, p. 18-19).

Para Lamy (2010), a alfabetização flui como desafio, perspectiva, possibilidade e esperança, de que os seres humanos conquistem seu espaço, numa integração ao mundo vivido; como possibilidade e meio de transformação, sendo viva, dinâmica e cultural.

O termo Alfabetização pode ser entendido em dois sentidos principais. Em um sentido stricto, alfabetização seria o processo de apropriação do sistema de escrita alfabético. Para que o indivíduo se torne autônomo nas atividades de leitura e escrita, ele precisa compreender os princípios que constituem o sistema alfabético, realizar reflexões acerca das relações sonoras e gráficas das palavras, reconhecer e automatizar as correspondências som-grafia. é certo, portanto, que, na alfabetização, a criança precisa dominar o sistema alfabético, o que demanda que o professor trabalhe explicitamente com as relações existentes entre grafemas e fonemas. No entanto, esse aprendizado não é suficiente. $O$ aprendiz precisa avançar rumo a uma alfabetização em sentido lato, a qual supõe não somente a aprendizagem do sistema de escrita, mas também, os conhecimentos sobre as práticas, usos e funções da leitura e da 
escrita, o que implica o trabalho com todas as áreas curriculares e em todo o processo do Ciclo de Alfabetização. Dessa forma, a alfabetização em sentido lato, se relaciona ao processo de letramento, envolvendo as vivências culturais mais amplas (CADERNO 1 Pnaic 2014, p. 29).

Assim, a autora ressalta a necessidade da formação dos professores alfabetizadores, a ser construída no cotidiano profissional; como aprofundamento dos saberes docentes, novas reformulações teóricas, reflexão permanente e apropriação dos conhecimentos teórico-metodológicos para aprimoramento das práticas pedagógicas, de modo a favorecer a aprendizagem dos seus alunos.

É preciso despertar nos alunos o gosto pela leitura e fundar as bases para a formação de leitores críticos. O uso da língua, tanto nos gêneros orais quanto escritos, requer que se observe sua historicidade, seus contextos, suas determinações sociais. $O$ uso dinâmico da língua é determinado por aqueles que desenvolvem as práticas de oralidade, escrita e leitura da língua. O trabalho interdisciplinar pode ser realizado com apoio na oralidade, leitura e escrita (CADERNO 1 Pnaic 2015, p. 19).

Em uma concepção de alfabetização focada na inserção das crianças nas práticas sociais, podem ser desenvolvidas metodologias que, de modo concomitante, favoreçam a apropriação do sistema alfabético de escrita por meio de atividades lúdicas e reflexivas e a participação em situações de leitura e produção de textos, ampliando as referências culturais das crianças (MANUAL LIVRETO Pnaic, p. 21).

O que é decisivo para o êxito da alfabetização na idade certa? Há vários fatores envolvidos no processo de alfabetização, mas três, em especial, merecem ser destacados. Em primeiro lugar, é fundamental contar com professores alfabetizadores bem preparados, motivados e comprometidos com o desafio de orientar as crianças nesta etapa da trajetória escolar.

Um segundo fator importante é a disponibilidade de materiais didáticos e pedagógicos apropriados e que estimulem a aprendizagem, tais como livros didáticos, paradidáticos, obras de literatura, jogos e mídias variadas. Todavia, não basta dispor desses materiais, é fundamental que os professores saibam manuseá-los e extrair dos conteúdos o máximo de possibilidades para dinamizar as aulas e alcançar os objetivos da alfabetização em cada ano (MANUAL LIVRETO Pnaic, p. 21).

Portanto, esses eixos de análise documental estabelecem relação com o concreto retratado nos trechos extraídos dos documentos oficiais e dos cadernos de formação do Pnaic, compostos por indicadores articulados que carregam e expressam a totalidade do objeto constituindo as suas categorias, ou seja, as categorias analíticas. 


\section{5 - Categorias analíticas}

O processo de análise continua com um movimento de articulação entre os indicadores e as categorias que emergem do objeto. Marx (2008) expõe a lógica dialética, que é o processo de construção do concreto pensado, parte-se do empírico, passa-se pelo abstrato e chega-se ao concreto. O concreto real é o ponto de partida e concreto pensado é o ponto de chegada.

Desse modo, partimos dos documentos da formação do Pnaic, que retratam o nosso objeto concreto e real, para, a partir da análise documental, propormos determinações e mediações a fim de que possam ser reveladas as categorias constitutivas do objeto em estudo; colaborando assim para a transformação da realidade e dos sujeitos envolvidos nesse contexto.

As categorias que emergem do objeto são determinantes fundamentais para produzir conhecimento sobre o mesmo, num plano teórico e abstrato, objetivando reproduzir o concreto pensado, não na sua realidade imediata, e sim na sua totalidade real. Marx (2008) propôs um procedimento do abstrato (determinações simples e gerais) ao concreto, que então não é mais a representação caótica de um todo, e sim, uma rica totalidade de determinações e de relações diversas, a unidade na diversidade. Assim, articulando os indicadores estabelecidos, inferimos, abstraímos e sistematizamos as categorias do objeto, buscando, compreender a política pública do Pnaic e suas concepções de formação continuada.

É importante ressaltar que, para nos aproximarmos de uma apreensão mais global do sujeito, é necessária a articulação de todas as categorias do objeto. Nesse movimento de articulação das categorias entre si, com as mediações sociais, históricas e ideológicas, com os conhecimentos produzidos sobre o objeto em pesquisa, surge uma nova realidade, mais complexa, integrada, reveladora das contradições e do movimento, ou seja, o concreto pensado. Assim, a partir desse movimento de articulação das categorias que emergem do objeto e das categorias centrais de análise documental, I) Concepções de formação continuada docente (epistemologia da racionalidade técnica, epistemologia da prática e epistemologia da práxis, II) Relação teoria e prática e III) Estrutura da formação); por meio da faculdade da abstração, buscamos ir além do que os documentos da formação do Pnaic registram, a fim de identificar os processos que a explicam e implicam.

Para Shiroma, Campos e Garcia: 
Partindo do suposto da política como processo, uma contribuição interessante para a análise desses documentos parece decorrer da exploração das contradições internas às formulações, posto que os textos evidenciam vozes discordantes, em disputa. É nesse campo de disputas que a "hegemonia discursiva" se produz, uma tendência crescente à homogeneização das políticas educacionais em nível mundial (2005,p.431).

Por essa razão, reconstruindo o caminho de volta à empiria de onde partimos, realizando inúmeras relações e aproximações entre os pré-indicadores e indicadores analisados nos documentos, elencamos algumas categorias que emergem do nosso objeto de pesquisa: i) Mudança de identidade profissional docente, ii) Relação teoria e prática, iii) Professor reflexivo, iv) "Multiprofissional", v) Responsabilização do professor e qualidade da educação, vi) Formação na perspectiva do Multiplicador, vii) Formação e valorização docente, viii) Perfil alfabetizador, xiv) Alfabetização cultural. Essas categorias são determinações do objeto. Elas contêm o todo, ou seja, representam a totalidade de nosso objeto e o conhecimento a respeito dele.

A categoria Mudança de identidade profissional docente sugere um movimento dialético e contraditório entre dois princípios propostos no caderno de apresentação da formação do PNAIC - o engajamento e a constituição da identidade profissional - pois traz elementos de formação individual e não de categoria de classe na perspectiva da consciência para si.

O princípio do engajamento evidencia que o professor deve privilegiar o gosto em continuar aprendendo e os momentos de reflexão sobre suas memórias enfatizam que esses elementos são importantes para a constituição como docente. Essa mudança de identidade profissional docente se pauta, portanto, numa identidade individual e não coletiva. Uma proposta de aprender a prática por meio da reflexão-na-ação que supervaloriza as práticas individuais, o que, consequentemente, limita a reflexão acerca dos problemas imediatos da prática profissional deslocada do contexto sócio-histórico, político e de classe profissional e se aproxima de uma formação de caráter instrumental e técnico.

Ferreira e Leal (2010) destacam que existe outro fator importante a se considerar, é que a formação continuada nem sempre depende do movimento ou iniciativa dos sujeitos em relação à participação e/ou realização das formações. Diferentemente da formação inicial, a opção em fazer parte ou não da formação, nem sempre se inscreve em um plano individual de interesse do 
professor, ou seja, nem sempre é uma decisão que ele toma sozinho. Muitas vezes, a formação está inserida em um discurso institucional que, a partir de diversos interesses, obriga o professor a participar de Programas de estudo que intentam fazer com que ele se desenvolva profissionalmente, no sentido de melhorar seu desempenho na sala de aula e, sobretudo, de melhorar a aprendizagem dos seus alunos. Consequentemente, seu poder de decisão sobre interromper ou dar continuidade à atividade é, muitas vezes, reduzido. Ele também pode ter baixa participação na definição das metas e estratégias formativas, o que resulta em conflitos com as agências responsáveis pela sua formação (CADERNO DE FORMAÇÃO Pnaic 2013, p. 11).

O engajamento: privilegiar o gosto em continuar a aprender é uma das metas primordiais da formação continuada e certamente faz parte da melhoria de atuação em qualquer profissão (CADERNO DE FORMAÇÃO Pnaic 2013, p. 15).

\begin{abstract}
Além de trazer à tona as experiências profissionais individuais, o exercício da memória em processos formativos favorece também a rememoração dos aspectos coletivos do vivido enriquecidos com experiências diferentes, relacionadas a um mesmo objeto, tema, situação ou prática (CADERNO DE FORMAÇÃO Pnaic 2013, p. 16).
\end{abstract}

Para Santos (2014), ao concentrarmos no aspecto da reflexão-na-ação, pode incorrer no risco de reduzir a compreensão de prática aos aspectos imediatos do ensino e da sala de aula, na medida em que desconsidera os determinantes e condicionantes da ação, como, por exemplo, os aspectos institucionais que influenciam o conteúdo e a forma da prática profissional. Freitas (1992) já alertava para a possibilidade de um novo tecnicismo na educação, na medida em que o processo de formação do professor estaria sendo reduzido a uma questão essencialmente prática e que essa prática vem sendo concebida pelas "novas" abordagens como problemas imediatos do cotidiano.

Sendo assim, num movimento histórico e contraditório, a formação de professores vem se afastando de uma perspectiva que toma a educação como prática social concreta; e a identidade profissional docente se torna fragilizada quanto à formação teórica, mas valorizada quanto ao aperfeiçoamento da prática e dos saberes técnicos para uma educação de qualidade. Nesse sentido, para Zeichner (1993) é importante que o professor atue como um profissional autônomo que reflete, de forma crítica, sobre sua prática, compreendendo o processo de ensino-aprendizagem em relação ao contexto em que ele se materializa, junto com as demandas advindas desse contexto. 
Evidencia-se que a reflexão da prática nos cursos de formação continuada denota o reconhecimento do papel ativo dos educadores, o seu engajamento e mudança de identidade profissional docente na construção do conhecimento e a valorização de suas próprias teorias pautadas na experiência, na ação pedagógica e na solução de problemas em sala de aula. Contudo, destacamos que o saber prático não é suficiente para fundamentar uma concepção que se proponha a compreender a multidimensionalidade do trabalho docente. Segundo Santos (2014), o olhar demasiado sobre as questões imediatas do ensino pode incorrer no risco de contribuir para o desenvolvimento de uma prática formativa baseada num praticismo e/ou na supervalorização do professor como sujeito individualizado.

O exercício da atividade docente requer uma formação intencional de caráter integral, que dê conta das tarefas do processo de ensino-aprendizagem circunscrito em contextos escolares, permeados por contradições, tensões e conflitos. Desse modo, a formação continuada, se constitui uma ferramenta necessária ao processo de profissionalização do professor, sendo parte de um processo inacabado, de permanente elaboração e reelaboração do trabalho pedagógico ao longo da vida profissional e mediada por relações sociais que envolvem essa atividade. Portanto, sinalizamos uma mudança de identidade docente pautada numa formação continuada como processo de preparação intelectual, técnica e política; como espaço de confrontação de conhecimentos, crenças, valores e experiências pessoais e coletivas e como processo de desenvolvimento humano e profissional.

Nessa direção, Santos (2014) considera que a formação continuada, compreendida como possibilidade de desenvolvimento pessoal e profissional, requer a superação de práticas formativas que apresentam características eminentemente prescritivas, normativas e pontuais, desprovidas de uma reflexão crítica sobre o ato pedagógico em sua totalidade. Nessa compreensão de identidade profissional docente, torna-se presente a categoria Relação teoria e prática. É nesta relação entre a prática e a teoria que se constrói também o saber docente, que é resultado de um longo processo histórico de organização e elaboração, pela sociedade, de vários saberes, e o professor é responsável pela transmissão deste saber produzido. A atividade prática implica a modificação do ideal em face das exigências do próprio real, requerendo um constante ir e vir de um plano a outro, o que só pode ser assegurado se a consciência se mostrar ativa ao longo de todo o processo prático e inseparável da finalidade. 


\begin{abstract}
As modificações impostas aos fins de que se havia partido para conseguir uma passagem mais cabal do subjetivo ao objetivo, do ideal ao real, só fazem demonstrar, ainda mais vigorosamente, a unidade entre o teórico e o prático ma atividade prática. Esta como atividade ao mesmo tempo subjetiva e objetiva, como unidade do teórico com o prático na própria ação, é transformação objetiva, real, na matéria através da qual se objetiva ou realiza um fim; é, portanto, realização guiada por uma consciência que, ao mesmo tempo, só guia ou orienta - e isso seria a expressão mais perfeita da unidade entre teoria e prática - na medida em que ela mesma se guia ou orienta pela própria realização de seus fins (VÁZQUÉZ, 2011, p. 266).
\end{abstract}

Num movimento contrário a essa relação teoria e prática, depreendemos dos documentos analisados, que a dimensão epistemológica que orienta a formação continuada do Pnaic se fundamenta na Epistemologia da prática; numa perspectiva de reflexão sobre a prática pedagógica, preconizando a prática profissional como fonte de conhecimentos e uma preocupação com a experiência pessoal e com a prática profissional como fonte de produção de saberes. O professor produz um determinado tipo de saber que valida sua ação e proporciona sua aprendizagem. Isso significa que a experiência, no exercício da atividade docente, é um fator importante na aprendizagem profissional, pois na vivência experimental se configura o conhecimento profissional que dá suporte ao trabalho do professor. Santos (2014) ressalta que a epistemologia da prática valoriza os saberes do fazer docente, preconizando a prática profissional como fonte de conhecimentos e contrapondo-se às perspectivas acadêmicas e técnicas que se pautam pela existência de um conhecimento exterior respaldado pela pesquisa científica.

Dessa forma, o princípio da socialização que orienta as ações do Pnaic no seu caderno de apresentação do programa, reforça essa relação teoria e prática pautada na Epistemologia da prática, fundada na "aprendizagem da prática, para prática e partir da prática" (SCHÖN, 2000). O professor é concebido como um sujeito que produz saberes a partir da sua experiência profissional. Ao desenvolver sua atividade prática numa realidade complexa, é constantemente desafiado a formular respostas para os problemas práticos do cotidiano do ensino. Sendo assim, Schön (2000) evidencia o papel que a experiência assume na estruturação desse tipo de saber. É a partir das experiências que as pessoas são levadas a darem respostas imediatas para problemas que se enquadram na estrutura de outros já resolvidos, validando os saberes existentes e/ou ressignicandoos a partir de novas perspectivas. 
Busca-se por meio da colaboração, nas formações, um aprendizado coletivo, através do qual os professores exercitem a participação, o respeito, a solidariedade, a apropriação e o pertencimento. O professor é ativo em sua própria profissionalização e é capaz de construir saberes cotidianamente, refletindo sobre sua própria trajetória, suas práticas e articulando saberes diversos (CADERNO DE FORMAÇÃO Pnaic 2013, p. 19).

\begin{abstract}
Além desses momentos, em cada encontro, sugere-se que sejam realizadas variadas estratégias voltadas para a reflexão sobre a prática, de modo articulado ao estudo teórico. Na página final do caderno de cada unidade são encontradas algumas sugestões que podem dinamizar os encontros de formação. Dentre essas sugestões, são encontradas atividades de produção oral e escrita de memórias, análise de recursos didáticos, análise de atividades e relatos de experiência, análise de sugestões de sequências didáticas, análise de instrumentos de avaliação e instrumentos de acompanhamento da aprendizagem das crianças (CADERNO DE FORMAÇÃO, Pnaic 2013, p. 31).
\end{abstract}

Ainda nesse contexto, o princípio de socialização estabelecido para a formação do Pnaic, insere o professor alfabetizador num processo de busca pela ampliação e apropriação de novos conhecimentos de natureza teórico-prática, atividades intencionais e sistematização do trabalho docente. Os professores são agrupados durante as formações com objetivo de trocar experiências, compartilhar práticas pedagógicas exitosas e aprender técnicas de ensino-aprendizagem que favoreçam o trabalho em sala de aula, principalmente no que tange à alfabetização na idade certa, bem como para as dificuldades encontradas no dia-a-dia de seu planejamento pedagógico. Destacamos assim, nos cadernos de formação, a importância dada ao planejamento escolar, às sequências didáticas, aos processos de aprendizagem e desenvolvimento das crianças, estratégias de trabalho docente. Cabe a todos os profissionais - neste caso, os professores - a busca pela formação continuada, pelos estudos e leituras, para que possam exercer a profissão que escolheram contribuindo para a promoção do ensino e da aprendizagem de todos os alunos como um direito constitucional que lhes é garantido (CADERNO 1, Pnaic 2015).

A análise da prática de professores durante os encontros pode levar os docentes a pensar em diferentes situações de sala de aula, que ainda não tenham vivenciado em seu dia a dia. $O$ pacto possibilita maior reflexão entre a teoria e a prática, contribuindo para a melhoria do fazer pedagógico do professor. Os momentos de socialização de experiências podem ajudar os docentes a pensar coletivamente ações para solucionar determinadas questões na sua prática diária. [...] podendo a partir dos encontros socializarem experiências e buscarem juntos soluções para os problemas de aprendizagem em suas salas (CADERNO DE APRESENTAÇÃO Pnaic 2015, p. 33). 
Com isso, temos o entendimento de que a categoria Relação teoria e prática vai dialogar com a categoria Professor reflexivo. Valorizando a experiência e a reflexão na experiência, a Epistemologia da prática enfatiza a prática profissional como momento de construção de conhecimento, através da reflexão, análise e problematização desta, e o reconhecimento do conhecimento na ação, presente nas soluções que os profissionais encontram na prática pedagógica. A partir desse diálogo, constrói-se a figura do professor reflexivo. O modelo de um profissional reflexivo reafirma a competência pessoal gerada por meio de reflexões sobre e na experiência vivida, consolidando o processo reflexivo como forma de investigação e não como descoberta do já existente.

Com base na ideia de valorização do saber do professor, a formação continuada desenvolvida pelo Pnaic tem o educador como sujeito de sua prática educativa. Nesse sentido, busca-se, durante o processo formativo, abrir espaço de discussão de modo que o professor assuma sua prática mediante a reflexão das experiências vividas, e são proporcionados momentos de estudos compartilhados e trocas de experiências, o que é coerente com o que estudiosos da área defendem, a exemplo de Nóvoa (1997) quando afirma que: a formação não se constrói por acumulação (de cursos, de conhecimentos ou de técnicas), mas sim através de um trabalho de reflexividade crítica sobre as práticas e de (re)construção da prática docente (CADERNO 1, Pnaic 2015).

No caderno de apresentação do Pnaic temos a prática da reflexividade como princípio dessa formação continuada. Segundo Libâneo (2012) reflexividade é uma característica dos seres racionais conscientes, todos os seres humanos são reflexivos, todos pensamos sobre o que fazemos. A reflexividade é uma autoanálise sobre nossas próprias ações, que pode ser feita consigo mesmo ou com os outros. Para Dewey (1979) a reflexão é entendida como uma relação direta entre a própria reflexividade e as situações práticas. Nesse caso, reflexividade não é introspecção, mas algo imanente à ação. Ela é um sistema de significados decorrente da experiência, ou melhor, formado no decurso da experiência. $\mathrm{O}$ ato inicial de pensar é a experiência.

Tendo a reflexividade como princípio da formação, o Pnaic propõe reflexão entre a teoria e a prática, buscando contribuir para a melhoria do fazer pedagógico do professor. Os momentos de socialização de experiências podem ajudar os docentes a pensar coletivamente ações para solucionar determinadas questões na sua prática diária. [...] podendo a partir dos encontros socializarem experiências e buscarem juntos, soluções para os problemas de aprendizagem em suas salas. As formações oferecidas 
seguem uma linha dinâmica, onde o professor é agente ativo no processo de construção do conhecimento. A oportunidade de reflexão sobre o fazer docente, o processo de ensino-aprendizagem, para discutir situações cotidianas, pensar nas necessidades do professor e do aluno e sobre temas do ensino (CADERNO 1, Pnaic 2015).

No entanto, de acordo com Contreras (1997) um profissional que reflete a ação deverá refletir também sobre a estrutura organizacional, os pressupostos, os valores e as condições de trabalho docente. Da mesma forma, Alarcão (1996) diz que o simples exercício da reflexão, entretanto, não é garantia de salvação dos cursos de formação de professores, pois a reflexão não é um processo mecânico. Deve, antes, ser compreendida numa perspectiva histórica e de maneira coletiva, a partir da análise e explicitação dos interesses e valores que possam auxiliar o professor na formação da identidade profissional; portanto, dentro de um processo permanente, voltado para as questões do cotidiano, através de sua análise e implicações sociais, econômicas, culturais e ideológicas.

Nesse sentido, Pimenta (2012) afirma que a reflexão deverá estar a serviço da emancipação e da autonomia profissional do professor. O professor como sujeito que não reproduz apenas o conhecimento pode fazer do seu próprio trabalho de sala de aula um espaço de práxis docente e de transformação humana. É na ação refletida e na redimensão de sua prática que o professor pode ser o agente de mudanças na escola e na sociedade. Para Ghedin (2012) a reflexão se dá numa realidade situada histórica e socialmente, do mesmo modo que supõe o corpo como portador da possibilidade reflexiva, e nesta situação de seu processo, encontram-se os seus limites. Porém, apesar de todos os limites impostos historicamente ao pensamento, este sempre se situou num horizonte de rompimento com a tradição e como instaurador de novas compreensões.

Assim, o processo reflexivo não surge por acaso, pois ele é resultado de uma longa trajetória de formação que se estende pela vida, pois é uma maneira de se compreender a própria vida em seu processo. Por isso a reflexão não pode se dá apenas sobre os conteúdos ou práticas pedagógicas, mas sim, uma reflexão sobre eles e suas causas geradoras. A compreensão de uma prática pedagógica inserida numa dada realidade social e histórica, em que os processos formativos oportunizem instrumentos teórico-metodológicos que permitam o professor adentrar o interior dessa prática e perceber não somente os aspectos aparentes, mas os seus elementos constitutivos, que vão além de uma visão reflexiva imediata. 


\begin{abstract}
Na perspectiva da prática pedagógica como estruturante da formação continuada, a prática pedagógica é compreendida como uma dimensão da prática social mais ampla, onde se configuram as relações sociais que influenciam o trabalho pedagógico da escola e do professor. Essa compreensão, por sua vez, implica não só no reconhecimento da experiência de cada professor, mas no entendimento do trabalho docente, como uma atividade intencional que se constrói na relação entre conhecimentos amplos e as questões da profissão e do ensino. Esse processo, por seu turno, requer um processo sistemático e permanente de reflexão entre os professores. Percebemos, nesse contexto, que a problematização e a reflexão têm relação com a capacidade criativa do sujeito, o que significa dizer que ambas exigem o domínio de conhecimento e habilidades. Enfim, problematizar a prática significa muito mais do que tão somente executar passos de uma técnica ou simplesmente descrevê-la. Daí a necessidade de que os processos formativos possam dispor de conteúdos que levem o professor a transcender os saberes imediatos. O que se pretende na realidade é a articulação entre o conhecimento teórico e o saber docente no currículo da formação do professor, tendo em vista que, na atuação pedagógica, o professor utiliza ambos os saberes (SANTOS, 2014, p. 71-73).
\end{abstract}

Na mesma direção, Pimenta (2012) aponta que o saber docente não é formado apenas da prática, sendo também nutrido pelas teorias da educação. Dessa forma, a teoria tem importância fundamental na formação dos docentes, pois dota os sujeitos de variados pontos de vista, para uma ação contextualizada, oferecendo perspectivas de análise para que os professores compreendam os contextos históricos, sociais, culturais, organizacionais e de si próprios como profissionais. Ghedin (2012) chama a atenção de que tudo isso supõe um processo de oposição ou de resistência a grande parte dos discursos, às relações e às formas de organização do sistema escolar, uma resistência a aceitar como missão profissional aquela que já aparece inscrita na definição institucional do papel docente. A aspiração à emancipação não se interpreta como a conquista de um direito individual profissional, mas como a construção das conexões entre a realização da prática profissional e o contexto social mais amplo, que também deve transformar-se.

Parece-nos então, que essa discussão sobre relação teoria e prática, atrelada à necessidade de um professor reflexivo, remete-nos o retorno às ideias de eficiência técnica em esferas distintas da educação, principalmente quanto à formação continuada docente. $\mathrm{O}$ modelo de organização e gestão do trabalho docente presente na atualidade coloca como imperativo o resgate da técnica e saber eficientes do professor, e novas relações entre concepção e execução decorrem nos modos de estabelecer esta relação; predominantemente quanto à discussão sobre o termo "qualidade" em educação com o objetivo de resolver os atuais problemas. E foi sob essa perspectiva que o MEC elaborou e implementou as políticas educacionais para a Educação Básica na década de 
1990 com estratégias para a descentralização da gestão educacional, as reformas curriculares e a implantação dos sistemas de avaliação. Tanto o Sistema Nacional de Avaliação da Educação Básica (Saeb) quanto os Parâmetros Curriculares Nacionais (PCN), projetados para redirecionar a Educação Básica, articularam-se para também orientar a formação dos professores numa perspectiva de eficiência e eficácia.

Segundo Santos (2014) no que tange à reforma dos conteúdos curriculares, a preocupação central do MEC voltou-se para a formação de um trabalhador polivalente, cujo conhecimento seja de caráter utilitário para as novas exigências do mercado de trabalho. Isso porque a educação na atualidade é pensada para além dos muros da escola, em prol da eficácia da aprendizagem e não do profissionalismo. Trata-se, assim, da exigência de saberes que vão além dos conhecimentos de docência, o que indica a necessidade de diferentes aprendizagens para quem assume a sala de aula, ou seja, um "multiprofissional". Desse modo, temos a categoria "Multiprofissional" relacionandose com a categoria Responsabilização do professor e qualidade da educação.

Cabe a todos os profissionais - neste caso, os professores - a busca pela formação continuada, pelos estudos e leituras, para que possam exercer a profissão que escolheram contribuindo para a promoção do ensino e da aprendizagem de todos os alunos como um direito constitucional que lhes é garantido. No Pnaic, tem-se estudado e refletido sobre diversos temas que suscitam mudanças na prática pedagógica e consequentemente possibilitariam a melhoria da aula ministrada, bem como rediscutido a prática e a teoria (CADERNO DE APRESENTAÇÃO DO Pnaic 2015, p. 16; 54).

O professor alfabetizador recebe, portanto, a função de auxiliar na formação para o bom exercício da cidadania e para exercer sua função de forma plena é preciso ter clareza do que ensina e como ensina, utilizando instrumentos variados que permitam analisar a progressão dos estudantes e suas relações com as estratégias didáticas adotadas; e estar atento de que o planejamento requer definição dos objetivos, ou seja, ter clareza do que se pretende dos alunos com relação à aprendizagem. Diante disso, uma ação didática consistente pressupõe necessariamente uma atividade diagnóstica para que o professor possa conhecer melhor os estudantes e reorganizar seu planejamento em função de suas necessidades (CADERNO DE APRESENTAÇÃO Pnaic 2013). Portanto, evidencia-se que o professor é um grande responsável por aumentar a qualidade da educação. Nesse sentido, o Pnaic, alegando valorizá-lo, utiliza 
palavras consensuais e alega entender a posição do professor, indicando nessa postura que o referido curso poderia subsanar esses problemas e desenvolver as competências necessárias para o exercício docente.

O docente "multiprofissional" destaca-se ainda como um dos agentes de transformação e melhoria da educação. Para isso, o professor deve saber avaliar, investigar e ter clareza das suas intencionalidades pedagógicas; deve planejar suas ações, mediar aprendizagem do aluno e transmitir a ele os conhecimentos necessários; deve refletir sobre sua prática e replanejar sua prática pedagógica buscando metodologicamente a melhoria do processo de ensino e de aprendizagem; que são inerentes ao trabalho docente. Mas, o discurso normativo, presente nos documentos e cadernos de formação continuada do Pnaic, apontam para a necessidade do professor ser também um investigador do que ensina, um facilitador do que se aprende, um mediador da aprendizagem, um educador cívico social e moral para formação do cidadão, um formulador do currículo a nível da sala de aula e um avaliador dos alunos e dos processos de ensino-aprendizagem.

\begin{abstract}
Como percebemos, os estudos realizados no Pnaic procuram articular as temáticas que emergem do cotidiano escolar, tais como planejamento, avaliação, interdisciplinaridade, currículo, e associá-las a estudos teóricos, a partir da problematização e da teorização, que repercutem no redimensionamento da prática pedagógica a partir das reflexões realizadas nos cadernos (CADERNO DE APRESENTAÇÃ̃ Pnaic 2015, p. 53).
\end{abstract}

Essa realidade complexa exige dos professores um perfil que solucione e resolva os impasses do cotidiano escolar, tomando como modelo de identidade um professor comprometido com a transformação da realidade social. É a partir das experiências vivenciadas constantemente em sua prática pedagógica, e da mobilização de conhecimentos, que o professor constrói sua identidade. A prática pedagógica é permeada por diversos fatores que devem ser levados em conta no ato reflexivo, entre eles a necessidade de considerar a heterogeneidade da sala de aula e os níveis de aprendizagem dos alunos, o que exige diferenciadas atividades pedagógicas (CADERNO DE APRESENTAÇÃO Pnaic 2015, p. 53).

Esse discurso também transpõe, muitas vezes, o que é função social coletiva de toda a comunidade escolar e até mesmo do Estado, para obrigações morais individuais do professor "multiprofissional". 
O professor deve ser um novo professor, uma pessoa psicologicamente madura e pedagogicamente formada, capaz de ser o instrutor e o facilitador da aprendizagem, o expositor e o individualizador do ensino, o dinamizador de grupos e o avaliador de performances, o animador e o controlador, o catalisador empático de relações humanas e o investigador, o que domina os conteúdos e o modo de os transmitir, o que ensina para se aprender e ensina a aprender a aprender (FORMOSINHO, 2009, P. 50-51).

A formação continuada aparece nesse contexto, como rede de experiências para melhoria dessa atuação docente, possibilitando um planejamento pedagógico reflexivo, o educador como sujeito de sua prática educativa e a instrumentalização pedagógica. Este novo trabalhador necessita, agora, de habilidades gerais de comunicação, abstração e integração, necessitando de uma formação continuada para aprofundamento de sua prática pedagógica. Como refere Formosinho (2009), as mudanças que se deram no trabalho dos professores podem ser entendidas como indício de um maior profissionalismo, devido a uma maior complexificação da função docente e à exigência de mais competências por parte dos professores, mas também podem ser identificadas com uma intensificação do trabalho do professor, da qual advém a deterioração e a desprofissionalização do trabalho dos docentes. Essa contradição alimenta e reforça nossa categoria de "multiprofissional", na medida em que o professor deve ser capaz de assumir e desempenhar com eficiência todas as especialidades propostas pelos discursos normativos, seja de formação inicial ou de formação continuada, como o Pnaic; e muitas vezes ainda subordinado a uma lógica individual e instrumental de aprendizagem.

Nessa perspectiva, a lógica neoliberal no contexto da educação, tem sido caracterizada por um conjunto de ideias que fazem apelo à "eficiência", à "eficácia" a "excelência", à "qualidade". Os professores, assim, são considerados como atores principais, "multiprofissionais", e o seu trabalho passa a ser visto como um sistema de ações concretas para resolver problemas concretos dentro da escola e da sala de aula. Torna-se evidente a categoria Responsabilização do professor e qualidade da educação. Portanto, a atuação de cada professor é fundamental para garantir o sucesso e a consolidação dos direitos dos estudantes, além do bom desempenho do Estado e suas políticas educacionais; sendo a qualidade da educação atrelada ao desempenho dos alunos nas avaliações externas e à consolidação da alfabetização na idade certa, no caso dos professores alfabetizadores. 


\begin{abstract}
Acresce, ainda, que o trabalho do professor desenvolve-se num contexto social de ambiguidades e contradições, numa realidade escolar em que convivem discursos a várias vozes, incidem projetos de sociedade plural, mobilizam-se referentes divergentes e se contrapõem a função seletiva e as finalidades personalizadora e democratizante de uma escola que, por um lado, acolhe alunos que lhe permanecem exteriores e, por outro, mantém a sua natureza de modernidade, e até de prémodernidade, num mundo "pós-moderno" (HARGREAVES, 1998, p. 16-17).
\end{abstract}

Nesse sentido, a nova organização dos Ciclos de Alfabetização, com a ampliação do Ensino Fundamental de oito para nove anos, instituída em 2004, definiu prioridades e metas da política educacional, principalmente quanto à "excelência" da alfabetização. A partir dessa proposta, o Pnaic, com o objetivo de elevar os índices de aprendizagem no Ciclo de Alfabetização e ter toda criança alfabetizada até no máximo os oito anos de idade, desenvolve sua formação continuada de forma a atender a prioridade maior que é elevar a qualidade do ensino, melhorando os resultados do desempenho dos alunos. Para isso, os professores alfabetizadores são inseridos numa política pública de formação centrada numa perspectiva do fazer pedagógico e na ação cotidiana, privilegiando a preparação técnica para o exercício da docência e uma nova cultura escolar de responsabilização individual dos professores pelo fracasso ou sucesso dos alunos, buscando através dessa ampla formação continuada, garantir a adesão aos princípios orientadores da sua proposta.

Para Apple (1995) o processo pedagógico, num movimento de rompimento com o passado, no qual o modelo tradicional representava um pensamento ultrapassado, foi expresso no discurso que valoriza a competição, a individualização, a responsabilização e a performance. Considerando esse contexto contraditório, o Pnaic, na medida em que investe na formação dos professores alfabetizadores, visa o sucesso da política educacional sob a via do consenso e da hegemonia, ou seja, o Estado educa e busca o consenso em torno do seu projeto. Nesse contexto, a formação continuada de professores possui um caráter compensatório, técnico e de responsabilização e a ênfase do trabalho passa a ser o produto da aprendizagem. O professor reflete sobre sua prática e retorna novamente à pratica, numa busca constante de tentar resolver os problemas de sua sala de aula. A formação continuada passa a ser pensada no formato escolar, trazendo, na maioria das vezes, a hipervalorização dos saberes experienciais, a dissociação entre tempos e espaços de formação e trabalho e a desarticulação entre os projetos formativos das instituições de formação; integrando a formação como instrumento de gestão estratégica e de desenvolvimento organizacional. 
Esse quadro tem assumido, segundo Dourado (2009), uma "tendência à banalização dos processos formativos, especialmente na formação de professores", ao mesmo tempo em que se preconiza a ideia da qualificação como elemento fundamental para a melhoria da qualidade de ensino. Quanto à formação continuada, o Plano de Desenvolvimento da Educação (PDE) reafirmou o discurso dessa formação como decisiva na conquista da melhoria do ensino ofertado pela Educação Básica. Nesse sentido, o plano sustenta o discurso de que "a melhoria da qualidade da educação básica depende da formação de seus professores, o que decorre diretamente das oportunidades oferecidas aos docentes" (PDE, 2007, p. 10). Para tanto, recomenda que essa formação seja desenvolvida por meio da Rede Nacional de Formação Continuada (RNFC) instituída em 2004, que deverá coordenar e implementar os programas como o Próletramento e o Pnaic; priorizando as áreas de Língua Portuguesa, Matemática e Alfabetização. O PDE sugere ainda que a formação continuada garanta um maior protagonismo dos docentes, privilegiando estudos e reflexões coletivas sobre a prática pedagógica, e as finalidades ficam subordinadas a uma perspectiva de melhoria do ensino e da aprendizagem do aluno.

A institucionalização da Rede permitiu o desenvolvimento, em universidades, de uma gama variada de materiais didáticos, destinados aos professores em serviço, além de ações desenvolvidas nos Estados e Municípios através dos Centros de Pesquisa e Desenvolvimento da Educação, parceiros na oferta de programas de formação continuada. Segundo Santos (2014), vemos emergir uma perspectiva de formação continuada que visa à melhoria da qualidade do ensino, sobretudo daqueles aspectos vinculados aos indicadores de desempenho que denotam fragilidades nas aprendizagens dos alunos. O foco da formação é, portanto, a aprendizagem do aluno, mas não qualquer aprendizagem e, sim aquela que garanta a aquisição de determinadas competências. Assim, com o objetivo de promover a melhoria do ensino e da aprendizagem do educando, a Rede tem se pautado numa concepção de formação continuada orientada pela reflexão permanente na/sobre a prática pedagógica, pela instrumentalização teórico-prática do professor ou pela atualização de conteúdos curriculares e técnicas de ensino num processo de troca/compartilhamento de experiências.

Nessa direção, percebemos um elemento de contradição e mediação quanto ao desenvolvimento da formação continuada pela Rede, no que tange a oferta de cursos à distância, com a parceria dos Centros de Pesquisa e com ajuda de professores tutores. Emerge desse contexto a categoria Formação na perspectiva do multiplicador. Os 
professores recebem mais uma demanda e responsabilidade: serem os orientadores de estudo, tutores, mediadores, facilitadores do trabalho pedagógico e multiplicadores da formação continuada.

O Pacto Nacional pela Alfabetização na Idade Certa prevê, como uma de suas ações, a formação de professores alfabetizadores. Essa ação se dá por meio de um curso, que apresenta uma estrutura de funcionamento na qual as universidades, secretarias de educação e escolas deverão estar articuladas para a realização do processo formativo dos professores atuantes nas escolas, nas salas de aula. Essa estrutura é composta por dois formadores diretamente sintonizados com os objetos de estudo e com a sala de aula, ou, como dizemos, com o chão da escola. O primeiro, o professor formador, que realizará a formação dos orientadores de estudo, é vinculado às universidades públicas brasileiras. $O$ orientador de estudos, organizará, com base nos mesmos princípios formativos, a formação dos professores atuantes nas escolas dos três primeiros anos, em diversas regiões do país. Esse "triângulo" formado, deverá estar muito bem articulado entre si, mobilizando diferentes saberes, os quais, de uma forma ou de outra, se materializarão em práticas escolares (CADERNO DE FORMAÇÃO Pnaic 2013, p. 24).

Quanto ao Pnaic, temos a formação continuada presencial para os professores alfabetizadores e seus orientadores de estudo, buscando a ampliação das discussões sobre a alfabetização na perspectiva do letramento; tendo como objetivo apresentar encaminhamentos metodológicos que possibilitem o desenvolvimento dos direitos das crianças dentro do ciclo de alfabetização. Segundo a Medida Provisória n ${ }^{\circ}$ 586, de 8 de novembro de 2012:

Art. $2^{\circ}$ - A Formação Continuada de Professores Alfabetizadores utilizará material próprio a ser fornecido pelo MEC a todos os orientadores de estudo e professores alfabetizadores cursistas e será ofertada de forma presencial, com duração de: I - duzentas horas anuais, incluindo atividades extra-classe, para os orientadores de estudo; e II - cento e vinte horas anuais, incluindo atividades extraclasse, para os professores alfabetizadores.

Art. $3^{\circ}$ - A Formação Continuada de Professores Alfabetizadores, ofertada por instituições de ensino superior (IES) formadoras definidas pelo MEC, será ministrada aos orientadores de estudo que, por sua vez, serão os responsáveis pela formação dos professores alfabetizadores.

Nessa perspectiva, destacamos o professor multiplicador inserido no Pnaic, seja na função de orientador de estudos ou como professor alfabetizador na escola, como responsável pela dinâmica e implementação da política de formação continuada, 
implicando num movimento contraditório de supervalorização da prática e experiência pedagógica, que poderá contribuir para a fragilização da própria formação; na medida em que pode minimizar o conhecimento teórico e enredá-lo em questões imediatas do ensino e do cotidiano escolar, limitando o trabalho docente em sua totalidade.

\begin{abstract}
Outro aspecto de contradição que observamos com relação à RNFC é a reafirmação de uma tendência de formação, que se desenvolve por meio de cursos a distância, com a ajuda de professores tutores. A tutoria é uma prática já bastante questionada no âmbito da formação docente, em virtude de alguns fatores. Em primeiro lugar, vale apontar que a presença de formadores na categoria de tutores parece negar ao professor da Educação Básica as mesmas condições de formação. Em segundo lugar, somos do entendimento de que o trabalho de tutoria, dependendo das condições em que se realiza, tem uma tendência que implicaria uma prática baseada na reprodução de determinados conhecimentos, o que imprimiria uma concepção de formação continuada de natureza mecanicista. E, em terceiro, destacamos que a presença do professor tutor contribui para a valorização do magistério, na medida em que esse profissional não possui as mesmas condições de trabalho, salariais e funcionais que um professor titular/efetivo (SANTOS, 2014, p. 140).
\end{abstract}

Segundo a Associação Nacional pela Formação dos Professores - Anfope a formação continuada deve estar associada ao exercício profissional do magistério, possibilitando atualização, aprofundamento, complementação e ampliação de conhecimentos profissionais que permitam ao professor, inclusive, ascender na carreira e ocupar funções mais elevadas. Ao mesmo tempo deve ser capaz de fundamentar o profissional da educação para contribuir para o desenvolvimento de projetos políticopedagógicos das instituições educativas em que atua, de respeitar a área de conhecimento do trabalho e de resguardar o direito ao aperfeiçoamento permanente do professor. É necessário também que a formação continuada se torne um elemento de avaliação, reformulação e criação de cursos de formação de profissionais da educação, ao mesmo tempo em que seja garantido o direito do profissional da educação e do trabalhador da educação de intervir na definição das políticas de sua formação, inclusive através de suas organizações sindicais (ANFOPE, 2004, p. 30).

Dessa forma, a formação continuada não deve ser de responsabilidade individual, mas sim numa dimensão da totalidade do trabalho docente, para se compreender o papel da educação na formação do homem e o papel do professor responsável por essa educação na escola. Por isso, Freitas (2007) afirma a importância de se estabelecer uma política global de formação dos professores, aliada às políticas de 
valorização desses profissionais, contemplando articulada e prioritariamente a formação inicial, continuada, condições de trabalho, salários e carreira.

A partir dessa afirmação, destacamos a categoria Formação e valorização docente. Cabe ressaltar que todas as reflexões sobre formação continuada desejada ou necessária para o exercício da profissão docente envolvem diretamente as reflexões sobre as condições de trabalho desse profissional, o que parece estar desarticulado nos documentos orientadores e de formação do Pnaic; pois os mesmos tratam da formação continuada, mas não abordam a questão do trabalho docente e as próprias condições de realização da proposta metodológica do Pnaic, desvinculando a formação da materialidade do trabalho docente, pois só as mudanças nas relações de trabalho podem transformar a realidade.

\begin{abstract}
No geral, as políticas de formação inicial e continuada de professores, instauradas pós-LDB distanciaram-se desse horizonte, na medida em que privilegiaram políticas e práticas que concorreram para o fortalecimento de modelos neotecnicistas de formação, cuja ênfase recaiu na instrumentalização e no aligeiramento da formação do professor. No que tange às mudanças observadas no campo da valorização, essas ainda são bastante tímidas e indicam a emergência de ações políticas que valorizem a educação e a formação de professores, com rebatimento nas condições de trabalho. Embora o PDE tenha centrado seus argumentos na qualidade da Educação Básica e na inclusão social, as medidas adotadas pelo governo ainda estão distantes de propiciar uma política de valorização que combine formação, melhores condições de trabalho, carreira profissional e remuneração (SANTOS, 2014, p. 143).
\end{abstract}

A maior parte da formação continuada de professores é recente e sua organização sofreu influências, nas últimas décadas, de uma concepção de formação continuada baseada numa lógica de reciclagem, treinamento, aperfeiçoamento e atualização dos conhecimentos do professor, as quais se cristalizaram numa prática formativa, cuja característica se pauta no seu caráter instrumental e de reflexão sobre a prática. Outra percepção importante, diz respeito ao caráter de descontinuidade das práticas e dos programas de formação; que dificulta a materialização de uma concepção de formação continuada de forma organizada, sistêmica e historicamente construída. Essa descontinuidade contrapõe-se à ideia da formação como um processo que se realiza num movimento dialético, de idas e vindas, em que o profissional se constrói e reconstrói como pessoa e como profissional. Assim, transfere-se para a formação continuada e para a reflexão sobre a prática, um caráter de solução para os problemas educacionais e também de melhoria da qualidade do ensino. 
Como sinalizamos anteriormente, as práticas formativas vivenciadas nos dias atuais traduzem contradições que vão além dessas questões epistemológicas. De um lado temos novas proposições que ressaltam a importância da formação do professor reflexivo e investigador de sua prática, de outro a figura do docente multiprofissional com a intensificação das atividades laborais e a precarização das condições de trabalho, em decorrência das exigências postas pela sociedade contemporânea; e mais ainda, os contextos educacionais que, dadas as suas limitações, não apresentam as condições necessárias ao desenvolvimento de uma formação emancipadora. Além desses fatores, há ainda a situação desfavorável nos aspectos referentes à carreira docente e aos salários, que reforçam os resultados de determinadas condições históricas que favoreceram a materialização de práticas formativas precárias e flexibilizadas.

\begin{abstract}
Isso significa que não são somente os conteúdos da formação que necessitam ser modificados. Enfatizamos aqui a importância de uma nova postura política no trato com a educação e com as questões da formação de professores. Importa-nos evidenciar que nenhum movimento de inovação das práticas de formação continuada terá grandes possibilidades de avanço, se não forem garantidas às escolas e aos professores as condições objetivas necessárias para o desenvolvimento do seu trabalho e de sua formação. Dessa forma, pensamos que qualquer proposta de formação há de vir acompanhada de ações políticas que incluam melhorias na organização do trabalho pedagógico, na carreira do magistério e nos salários, o acesso às diversas formas de produção e socialização do conhecimento, a existência de relações interpessoais e institucionais favoráveis ao compartilhamento das experiências e a garantia de espaço/tempo para o exercício sistemático da reflexão. Significa, ainda, valorizar o potencial criativo e transformador na construção de projetos e suas utopias (SANTOS, 2014, p. 86).
\end{abstract}

Pensar numa concepção de formação, que toma o professor como protagonista dos projetos educativos, que buscam a reinvenção da escola e de suas práticas e de seu processo de formação, pode contribuir para explicitar as contradições de uma realidade socialmente construída, que, por um lado, apresenta discursos em torno da melhoria do ensino, da aprendizagem do aluno e da formação docente, mas por outro, comprime cada vez mais as condições necessárias à valorização do profissional do magistério e da educação. Por isso, a Anfope (2004) afirma a importância de uma política global de formação de professores que contemple desde a sua formação básica até as condições de trabalho e formação continuada, como espaço de construção, revisão, confronto e ampliação dos conhecimentos profissionais; além de ter como primordial a garantia de uma sólida formação teórica. 
Nesse contexto, além da formação básica, as exigências da sociedade neoliberal passaram a requerer uma formação permanente do trabalhador, considerando a possibilidade de desatualização do conhecimento, os avanços científicos e tecnológicos e as mudanças sociais. Isso desencadeou a premissa de que o professor precisa de um processo permanente de formação, e até mesmo especializado quanto à alfabetização, com vistas à melhoria do aprendizado e do ensino. Há também o fato de que, mesmo que o acesso à escola tenha sido democratizado a partir da década de 1990, em muitas regiões do mundo, a qualidade da educação - e principalmente da alfabetização - não é suficiente para que se adquiram condições para continuar aprendendo. Além disso, segundo Gontijo (2014) a alfabetização é vista como um importante anunciador dos níveis de desenvolvimento, de diminuição das desigualdades sociais e de pobreza. Por isso mesmo, o aumento do analfabetismo e a não frequência à escola pelas crianças são considerados indicadores que expressam subdesenvolvimento e pobreza.

Neste novo cenário, destaca-se a necessidade dos professores alfabetizadores reconhecerem uma proposta mais ampla de alfabetização, com ações inovadoras, capazes de superar os obstáculos que têm limitado a plena alfabetização por grande parte das crianças; tornando o ensino mais eficaz e a aprendizagem mais significativa.

O Pnaic quer alfabetizar todas as crianças e, para isso, cabe aos professores planejarem suas ações pedagógicas, preocupando-se com todas as crianças igualmente, e produzindo estratégias que possam envolver o coletivo da sala de aula em todas as atividades, mesmo que os recursos e materiais precisem atender as necessidades individuais de algumas crianças por suas particularidades (CADERNO DE APRESENTAÇÃ̃O Pnaic 2015, p. 29).

Destaca-se também a exigência de saberes que vão além dos conhecimentos de docência, o que indica a necessidade de aprendizagens específicas para quem assume a função de professor alfabetizador. Com base no exposto, podemos perceber a categoria Perfil alfabetizador, ou seja, um "tipo novo" de professor, cuja função se paute nas referências da eficácia social e da competência para resolver os problemas e os desafios do cotidiano no Ciclo de Alfabetização. 
O ciclo de alfabetização deve garantir a inserção da criança na cultura escolar, bem como a aprendizagem da leitura e da escrita e a ampliação de seu universo de referências culturais, nas diferentes áreas do conhecimento. Ao final do ciclo de alfabetização, a criança tem o direito de saber ler e escrever, com domínio do sistema alfabético de escrita, textos para atender a diferentes propósitos. Considerando a complexidade de tais aprendizagens, concebe-se que o tempo de 600 dias letivos é um período necessário para que seja assegurado a cada criança o direito às aprendizagens básicas da apropriação da leitura e da escrita; necessário, também, à consolidação de saberes essenciais dessa apropriação, ao desenvolvimento das diversas expressões e ao aprendizado de outros saberes fundamentais das áreas e componentes curriculares, obrigatórios, estabelecidos nas Diretrizes Curriculares Nacionais para o Ensino Fundamental de Nove Anos. (MANUAL LIVRETO Pnaic, 2013, p. 17).

Isso tudo, por sua vez, exige a formação dos professores alfabetizadores, num contexto de aperfeiçoamento dos saberes docentes e da alfabetização como prática social e apropriação cultural. E nessa perspectiva, a formação continuada do Pnaic reafirma esse Perfil Alfabetizador, sinalizando o professor alfabetizador como o problematizador e mediador das hipóteses das crianças; tendo para isso, conhecimento da realidade linguística dos alunos e sensibilidade aos seus problemas sociais e sendo seu papel criar condições pedagógicas para que a criança reelabore as suas hipóteses durante o processo de alfabetização.

Em primeiro lugar, é fundamental contar com professores alfabetizadores bem preparados, motivados e comprometidos com o desafio de orientar as crianças nesta etapa da trajetória escolar (MANUAL LIVRETO Pnaic, 2013, p. 19).

O desenvolvimento de competências alfabetizadoras passa a ser condição para que os professores alfabetizadores ensinem todos os seus alunos a ler e escrever. Não é possível ensinar a todos, quando não se sabe ensinar na diversidade e complexidade que se apresenta a maioria das séries iniciais. Diversidade de contextos, de saberes, de condições materiais, entre tantas outras. Obter sucesso no ensino apenas daqueles que iriam aprender de qualquer forma, por viverem em um contexto que oferece condições e favorece suas aprendizagens, parece algo irrelevante na atuação docente do professor alfabetizador.

Por isso, Costa e Fuck (2010) consideram que o desafio que se coloca para o professor alfabetizador consiste em ensinar também os menos privilegiados da 
sociedade para que tenham tanta competência quanto os outros, vendo garantido o seu direito de aprender. Assim, a formação continuada, como o Pnaic busca estimular a elaboração de atividades, a implementação dessas na sala de aula, a troca de experiências e a refletir sobre essas atividades e experiências para que os alunos tenham êxito no aprendizado. Assim percebemos um movimento de afirmação ao Perfil Alfabetizador.

O papel do professor alfabetizador é central, não cabendo confundi-lo como o de alguém que na sala de aula irá reproduzir métodos e técnicas. $O$ professor alfabetizador deve ser pensado como um profissional em constante formação, não só na área de linguagem, mas em todas as áreas do conhecimento que façam parte do ciclo de alfabetização (CADERNO DE APRESENTAÇÃ̃o Pnaic 2014, p. 30).

O professor regente será, sempre, a melhor pessoa para avaliar o que precisa ser retomado e criar estratégias para que essa retomada atinja o objetivo: a aprendizagem e alfabetização matemática dos alunos. Para atingir este objetivo mais geral, o professor deverá ter em mente objetivos específicos relativos a cada semana, em relação a um dado item do currículo ou conteúdo a ser trabalhado (CADERNO DE APRESENTAÇÃO Pnaic 2014, p. 31).

A importância do professor alfabetizador na formação das crianças, já que, para garantir a todas elas o direito a ler e escrever com autonomia, é preciso percorrer um caminho especializado de integração de saberes (CADERNO DE APRESENTAÇÃO Pnaic 2015, p. 54).

O professor alfabetizador traz em suas ações representações, valores e demandas específicas para atuar no Ciclo de alfabetização. A contradição está exatamente entre a exigência no perfil para atuar como professor alfabetizador e as condições de trabalho como multiprofissional, além das relações teoria e prática, estabelecidas numa formação continuada pautada na Epistemologia da prática.

E esse perfil exigido para o professor alfabetizador é também reafirmado pela categoria Alfabetização cultural. Isso porque a compreensão do significado da alfabetização progrediu consideravelmente com as ideias da sociolinguística propostas na década de 1990 e início dos anos 2000. A postura atual, sem negar o processo de codificação e decodificação da língua, aborda o problema da alfabetização como um processo sociocultural mais complexo, que assume uma multiplicidade de formas, usos e significados e se insere em diferentes contextos sociais. Esse processo considera a 
diversificação de usos e formas e de entendimentos em relação à comunicação interpessoal. A aprendizagem da leitura e da escrita é vinculada à vida cotidiana e seu uso constitui uma forma de participação do cidadão na sociedade.

Com essa compreensão dos múltiplos enfoques no conceito de alfabetização cultural numa perspectiva do letramento e no papel do mediador-alfabetizador, a alfabetização não é meramente uma habilidade técnica a ser dominada, mas sim um fenômeno socialmente construído, não se limitando apenas ao domínio da escrita e da leitura; mas exigindo do professor alfabetizador uma formação específica, programas de preparação para a alfabetização, regionalização do ensino e material didático, e até mesmo um pacto nacional que valide propostas de ensino e objetive a alfabetização das crianças na idade certa.

A perspectiva assumida, portanto, é de uma alfabetização viva, em que as crianças se apropriem da leitura e da escrita de modo ativo, agindo socialmente: ler e escrever para interlocutores que assumem diferentes papéis sociais, e não apenas para o professor, para atender a diferentes propósitos, contextualmente situados. $O$ objetivo é que as crianças aprendam a ler e escrever, mas também aprendam por meio da leitura e da escrita (CADERNO DE APRESENTAÇÃ̃O Pnaic, 2013, P. 22).

É ressaltado que ser alfabetizado é muito mais do que dominar apenas os rudimentos da leitura e escrita, mesmo sendo capaz de ler e escrever todas as palavras. A pessoa alfabetizada é aquela que é capaz de ler e escrever em diferentes situações sociais, de tal forma que isso lhe permita inserir-se e participar ativamente de um mundo letrado, enfrentando os desafios e demandas sociais. Para que isso aconteça não basta apenas o domínio dos conhecimentos relacionados à linguagem, é necessário também um amplo domínio do campo relacionado à matemática, no qual os números e o sistema de numeração decimal são fundamentais, mas não são os únicos aspectos que devem ser abordados na escola (CADERNO DE APRESENTAÇÃo Pnaic, 2014, p. 18).

No universo da alfabetização, entendemos a importância de ressaltar o processo da criança se alfabetizar cultural e esteticamente, de modo que o mundo do sensível esteja lado a lado com a razão, criando significado próprio à aprendizagem (CADERNO DE APRESENTAÇÃO Pnaic, 2015, p. 21).

É preciso salientar que o valor atribuído à alfabetização, como fator essencial para a operação de mudanças na sociedade e nos indivíduos, não ajuda a romper com esse conceito, especialmente porque reedita as ideias neoliberais de que a alfabetização 
é elemento fundamental para o desenvolvimento das sociedades modernas e dessa forma indispensável para o desenvolvimento social e econômico, para a democratização política e a cidadania, para a ampliação da consciência e da identidade; sem levar em conta que o analfabetismo é resultado dos processos de exclusão e de marginalização gerados por sociedades fundadas na exploração do trabalho e, portanto, dos seres humanos.

É importante acentuar que a compreensão da alfabetização deve levar em conta, sobretudo, os contextos históricos e sociais em que ela ocorre e, desse modo, precisa ser concebida como prática social e cultural que se desenvolve de diferentes maneiras, em diferentes contextos, para atender a finalidades específicas dos grupos humanos que utilizam a leitura e a escrita para fins sociais, profissionais, entre outros. Porém, não se pode perder de vista que a alfabetização precisa tornar-se um elemento fundamental para a libertação e mudança social (GONTIJO, 2014, p. 4).

Esse movimento dinâmico é um dos aspectos centrais do processo de alfabetização, possibilitando o homem de escrever, reescrever e transformar o mundo por uma prática consciente. Dessa maneira, a categoria Alfabetização cultural, num cenário neoliberal de busca pela eficiência e eficácia da educação, estabelece a formação docente pautada em competências e habilidades necessárias para o alcance da alfabetização plena num contexto social e hegemônico. Segundo Freitas (2007), encontra-se nessa comparação a lógica de que a mensuração do desempenho do estudante é diretamente proporcional à qualidade do trabalho do professor. Isso significa o retorno do tecnicismo, numa vertente "neotecnicista", revestido de outros princípios da racionalidade técnica - eficiência e produtividade - estabelecido nas políticas nacionais de formação de professores alfabetizadores pautadas na epistemologia da prática.

Um segundo fator importante é a disponibilidade de materiais didáticos e pedagógicos apropriados e que estimulem a aprendizagem, tais como livros didáticos, paradidáticos, obras de literatura, jogos e mídias variadas. Todavia, não basta dispor desses materiais, é fundamental que os professores saibam manuseá-los e extrair dos conteúdos o máximo de possibilidades para dinamizar as aulas e alcançar os objetivos da alfabetização em cada ano (MANUAL LIVRETO Pnaic, 2013, p. 20). 
Disso decorre uma formação docente pautada na reflexão sobre a prática, na validação de experiências, na necessidade de formação continuada para suprir as necessidades do perfil alfabetizador e da alfabetização cultural e com ênfase no desenvolvimento de competências e qualidade do processo de ensino-aprendizagem. $\mathrm{O}$ professor torna-se, nesse contexto um colaborador efetivo das políticas de formação e dos padrões econômicos do capitalismo, transformando-se num profissional que executa tarefas para a criação de habilidades e competências necessárias para a atual sociedade do conhecimento.

Portanto, é preciso redefinir as políticas de avaliação e de formação de professores, fundamentadas na análise e na compreensão dos contextos históricos, sociais, culturais e organizacionais em todas suas dimensões, formas e práticas. Isso porque a formação não passa apenas pelo comprometimento e desprendimento de querer aprender e fazer do professor alfabetizador, mas é preciso investimento e políticas nacionais que lhe assegurem o direito a esta formação; bem como incentivos, valorização da profissão, planos de carreira e salários e condições no âmbito escolar para desenvolvimento de seu planejamento pedagógico.

\section{6 - Os cadernos de formação do Pnaic e os autores referenciados}

Todos os apontamentos elencados e a análise das contradições e mediações incorporadas nos cadernos de formação nos permitiu compreender as concepções de formação do Pnaic já que os cadernos norteiam principalmente a formação continuada do professor alfabetizador no Pnaic. No processo de reconstrução do caminho de volta à empiria de onde partimos, realizamos inúmeras relações e aproximações com as categorias que emergem do nosso objeto de pesquisa e os trechos extraídos dos cadernos de formação do Pnaic.

Assim, destacamos a relevância dos autores referenciados nos cadernos de formação para sustentação das concepções e também do direcionamento da política de formação docente do Pnaic. Abordamos assim, as referências autorais e teóricas agrupadas em áreas temáticas de estudo e de direcionamento da formação para os professores alfabetizadores no Pnaic: 


\section{QUADRO 5 - TEMÁTICAS DE ESTUDO E AUTORES REFERENCIADOS}

\begin{tabular}{|c|c|}
\hline $\begin{array}{c}\text { TEMÁTICAS DE } \\
\text { ESTUDO }\end{array}$ & AUTORES REFERENCIADOS \\
\hline $\begin{array}{c}\text { Alfabetização e o } \\
\text { ensino da língua } \\
\text { materna }\end{array}$ & $\begin{array}{l}\text { Emilia Ferreiro e Ana Teberosky } \\
\text { Telma Ferraz Leal e Ana Carolina Brandão } \\
\text { Magda Soares } \\
\text { Angela Kleiman e Sílvia Moraes } \\
\text { Piaget } \\
\text { Bakhtin } \\
\text { Vygotsky } \\
\text { Artur Gomes de Morais e Eliana Borges Albuquerque }\end{array}$ \\
\hline $\begin{array}{l}\text { Alfabetização e os } \\
\text { gêneros textuais }\end{array}$ & Bernard Schneuwly e Joaquim Dolz \\
\hline $\begin{array}{l}\text { Alfabetização e } \\
\text { letramento matemático }\end{array}$ & $\begin{array}{l}\text { Carlos Roberto Viana e Emerson Rolkouski } \\
\text { Cristiano Muniz }\end{array}$ \\
\hline $\begin{array}{l}\text { Alfabetização e } \\
\text { Currículo }\end{array}$ & $\begin{array}{l}\text { Antônio Zabala } \\
\text { Carlos Eduardo Ferraço. } \\
\text { Marinez Murta }\end{array}$ \\
\hline Formação docente & $\begin{array}{l}\text { Philippe Perrenoud } \\
\text { Maurice Tardif } \\
\text { Kenneth Zeichner } \\
\text { Donald Schön }\end{array}$ \\
\hline $\begin{array}{l}\text { Planejamento e } \\
\text { práticas docentes }\end{array}$ & $\begin{array}{l}\text { Janete Magalhães Carvalho e Carlos Eduardo Ferraço } \\
\text { Juliana de Melo Lima } \\
\text { Fernando Hernández e Montserrat Ventura } \\
\text { Valéria Lopes Nunes e Isabel Solé }\end{array}$ \\
\hline
\end{tabular}

Fonte: Elaborado pela pesquisadora a partir da análise dos Documentos do Pnaic em outubro de 2016. 
As proposições dos autores referendados nos cadernos de formação do Pnaic fortalecem a hipótese da contradição do movimento real e das políticas, pois da mesma forma que aparece a epistemologia da prática como concepção que legitima e sustenta essa política educacional, também há apropriação da perspectiva histórico-cultural; mas num formato de formação do multiplicador, sinaliza-se a fragilidade dessa perspectiva teórica para nortear a proposta de formação continuada do pacto.

Assim, num movimento dialético das categorias que emergem de nosso objeto de análise e compreendendo a formação continuada de professores alfabetizadores, enquanto política pública de educação, prática e discurso pedagógicos e processo de constituição da profissão docente; o professor alfabetizador é inserido na formação continuada do Pnaic, na busca de articular o individual e o coletivo social na ilusão de que, ao se conscientizar de suas práticas por meio da reflexão, ele terá condições de transformar a si mesmo, melhorar sua própria prática e, consequentemente, a qualidade da aprendizagem de seus alunos.

A leitura e análise documental entende formação a intensificação de uma visão pragmatista e tecnicista tanto do conhecimento como do trabalho pedagógico, ou seja, uma proposta de formação do professor reflexivo que enfatiza qualidades individuais e subjetivas materializadas em sua capacidade de realização pessoal, desconsiderando que o fazer do professor é o resultado de uma relação orgânica entre formação e condições efetivas de trabalho.

Esse movimento de analisar, refletir e tomar decisões exige e desafia o professor a repensar a sua prática pedagógica. $O$ repensar sobre a prática leva, a nós professores, a reconfigurações da própria prática pedagógica e coloca no centro das discussões o papel do professor como protagonista do seu desenvolvimento profissional, ou seja, da sua profissionalidade. Isso nos faz questionar como o professor, principalmente o alfabetizador, pode aprender continuamente por meio da reflexão sobre a sua prática pedagógica (CADERNO DE APRESENTAÇÃO Pnaic 2015, p. 53).

O processo formativo que tem a prática como ponto de partida e de chegada permite ao professor desenvolver uma sólida formação profissional (CADERNO DE APRESENTAÇÃO Pnaic 2015, p. 55).

No entanto, quando dialogamos com as categorias que emergem de nosso objeto - Mudança de identidade profissional docente, Relação teoria e prática, Professor reflexivo, "Multiprofissional”, Responsabilização do professor e qualidade da educação, 
Formação na perspectiva do multiplicador, Formação e valorização docente, Perfil alfabetizador, Alfabetização cultural - compreendemos que a práxis como ação humana transformadora pode superar e transformar esta realidade, numa visão de totalidade na relação trabalho, formação e educação.

\begin{abstract}
A formação e o trabalho docente na perspectiva crítico-emancipadora formam uma unidade, um único processo de desenvolvimento pessoal, intelectual, técnico e político-social e a qualidade do ensino se constitui nesta dialética formação-trabalho, que deve ser o fio condutor tanto dos cursos de formação (inicial ou continuada) quanto dos processos de ensino na escola. A práxis contém as dimensões do conhecer (atividade teórica) e do transformar (atividade prática), ou seja, teoria e prática são indissociáveis (SILVA e LIMONTA, 2013, p. 173).
\end{abstract}

\begin{abstract}
Entendemos a práxis como atividade material humana transformadora do mundo e do próprio homem. Essa atividade real, objetiva, é, ao mesmo tempo, ideal, subjetiva e consciente. Por isso, insistimos na unidade entre teoria e prática, unidade que também implica certa distinção e relativa autonomia. A práxis não tem para nós um âmbito tão amplo que possa, inclusive, englobar a atividade teórica em si, nem tão limitado que se reduza a uma atividade apenas material (VÁZQUEZ, 2011, p. 398).
\end{abstract}

Considerando a materialidade do trabalho decente como práxis e a possibilidade de uma consciência crítica e de novas práticas transformadoras da realidade social, a formação continuada pautada numa concepção crítico-emancipadora se materializa numa prática fortalecida de teoria, constituindo uma nova criação e um novo conhecimento; numa indissociabilidade teoria e prática na práxis, capaz de transformar o mundo natural e social para fazer um mundo humano.

Concebemos assim, a formação continuada como um processo de preparação intelectual, técnica e política que pretende responder às demandas e aos desafios presentes na realidade social. O exercício da atividade docente requer uma formação intencional de caráter integral, que dê conta das tarefas do processo de ensinoaprendizagem circunscrito em contextos escolares, permeados por contradições, tensões e conflitos. Evidencia-se também a importância da formação na construção da profissão docente e para qualificar o trabalho pedagógico; possibilitando a busca, a pesquisa, a ampliação e a apropriação de novos conhecimentos.

No que diz respeito à formação continuada de professores alfabetizadores, o que se espera e o que se deseja dela é a conjugação de aspectos teóricos-práticos, que favoreçam uma sólida formação teórica, a reflexão crítica, na valorização da escola 
como espaço de pesquisa e formação e na valorização dos professores como sujeitos produtores do saber. A pesquisa e a reflexão da prática profissional do professor são elementos que podem articular teoria e prática mediadas pelo trabalho e pela práxis, permitindo o docente compreender a realidade em um todo (VASQUEZ, 2011). Nesse sentido, assumimos uma concepção de formação de professores crítico-emancipadora, definida como uma concepção que procura construir a indissociabilidade de teoria e prática na práxis.

Quanto à formação dos professores alfabetizadores nessa perspectiva, pode-se afirmar que assim como o aluno constrói o conhecimento, o mesmo acontece com o professor. Os professores devem passar por experiências de aprendizagem para confrontar suas experiências particulares, suas crenças tradicionais, seus conhecimentos sobre o desenvolvimento psicológico das crianças. É compartilhando suas experiências com outros educadores que os professores podem questionar, refletir e construir a prática pedagógica nos moldes desenvolvimentalistas (CURADO SILVA, 2008).

A função social do conhecimento é enriquecer a própria existência humana - a práxis em sua dimensão transformadora. É na práxis que o homem deve demonstrar a verdade, isto é, a realidade e o poder, o caráter terreno do pensamento [...] não basta interpretar, o que importa é transformar (MARX, 2007, p. 19).

O professor precisa pensar sobre sua própria prática, pesquisar. A função docente é vista como exercício profissional e também humano, social. A pesquisa possibilita a práxis, unidade teoria e prática, e permite aos professores alfabetizadores ressignificarem sua atuação docente, produzindo conhecimentos sobre seu trabalho. Uma concepção de formação continuada numa perspectiva crítico-emancipadora, procura construir a indissociabilidade de teoria e prática na práxis; permitindo que através da pesquisa o professor possa ressignificar sua atuação docente, produzindo conhecimentos sobre seu trabalho. Diante disso, pensar a pesquisa para a formação de professores e atuação docente se faz necessário, pois permite a articulação teoria e prática, ou seja, a práxis docente. A formação continuada, compreendida como possibilidade de desenvolvimento pessoal e profissional, requer a superação de práticas formativas que apresentam características eminentemente prescritivas, normativas e pontuais, desprovidas de uma reflexão crítica sobre o ato pedagógico em sua totalidade. 


\begin{abstract}
Ao tomar como ponto de partida que o conhecimento é construído no interior de uma pedagogia da práxis bem como a consideração do professor e do aluno como sujeitos históricos que ao mesmo tempo em que são midificados pelas circunstâncias são capazes de nela atuar, modificando-as, torna-se possível que uma práxis transformadora possa ser desenvolvida no processo pedagógico de formação de professores e alunos dentro de uma perspectiva de trabalho como mediador e princípio educativo e não de modo polivalente, flexível e adaptável como propõem as políticas educacionais neoliberais (NORONHA, 2010, p. 17).
\end{abstract}

A formação continuada de professores na perspectiva crítico-emancipadora possibilita a práxis docente, oportunizando ao professor condições para ele teorizar sobre a prática, pois, nesse processo de teorização, ele realiza um esforço cognoscitivo que o ajuda a descobrir a prática pedagógica inserida num contexto mais amplo. Por outro lado, essa apropriação da realidade, que se efetiva por meio da relação teoriaprática, propicia determinadas aprendizagens que ajudam o professor a transformar o seu objeto de trabalho. Nesse contexto, a formação continuada assume uma ação humana emancipatória e transformadora que ocorre para a construção de novas possibilidades de ser da educação e da profissão docente. A práxis docente, o voltar na teoria a partir da prática, possibilita o conhecimento, a síntese e a crítica; e a pesquisa como forma de superar o senso comum e avançar na sistematização dele.

O espaço de coordenação pedagógica deve se transformar em pesquisa e estudo para tentar analisar alguns problemas da escola, extrapolando a perspectiva do modelo e do senso comum. Segundo Curado Silva (2008) a pesquisa é vista como uma atitude investigativa que inclui a predisposição para examinar a própria prática docente de uma forma crítica e sistemática, ou seja, a disposição questionante e a manutenção do estado de dúvida. Nessa forma de investigar a realidade, a primazia é do sujeito sobre o objeto, e é o sujeito que conhece e cria a realidade. E assim a formação, a aprendizagem e a condução do agir pedagógico se inserem num movimento dialético para pensar a condição humana, pessoal e social dos estudantes.

Marx e Engels diziam que os seres humanos fazem a história, não como querem, mas sob determinadas condições. Essas condições se apresentam cada vez mais contraditórias e indicam a necessidade urgente de construção do devir que exige, além da retomada da perspectiva analítica da totalidade, a rearticulação da teoria com a prática política e a retomada da unidade na luta, como forma de efetivo avanço na emancipação humana (PALUDO e VITÓRIA, 2014, p. 127). 
Com base nessas questões, nas categorias que emergem de nosso objeto de estudo e no debate acerca dos modelos teóricos que orientam a formação continuada na concepção da epistemologia da prática, reafirmamos a necessidade da formação docente, ser compreendida como uma atividade crítico-reflexiva-emancipadora e de natureza teórico-prática que concerne para o desenvolvimento e valorização pessoal e profissional do professor. A práxis transformadora, quando documentada, permite a renovação de conhecimento profissional prático; pois são, em grande medida, os projetos e as situações participativas de trabalho que proporcionam as oportunidades de formação.

\begin{abstract}
A definição de práxis em Marx é de ação transformadora consciente. Para ele é exatamente isso o que distingue o ser humano dos outros seres. E a práxis se expressa por meio do trabalho que é atividade criadora, produtora, realizadora. Por isso o trabalho é essencialidade humana e o elemento fundamental se constituição da sociabilidade. Por meio dele o ser humano se relaciona com a natureza e com os outros seres humanos, transformando a realidade que o cerca e a si mesmo (MASCARENHAS, 2014, p.178).
\end{abstract}

Nesse sentido, Mascarenhas (2014) afirma que o educar deve ocorrer na perspectiva do formar, humanizar e não deformar, nem cultivar a competitividade, o individualismo e a mercantilização do processo educativo. Assim sinalizamos a necessidade de uma política nacional de formação de professores, numa concepção pautada pelo desenvolvimento de sólida formação teórica e interdisciplinar no processo de constituição do trabalho e profissão docente.

Entendemos que será a partir da compreensão do trabalho docente que haverá a possibilidade de emancipação, pois trata-se de um movimento de articulação entre teoria e prática, por serem os homens produzidos através do trabalho, somente as mudanças ao nível das relações de trabalho podem transformar a realidade e, consequentemente, a consciência, mas é no ato de desvelar a realidade é uma das atitudes que podem construir possibilidades de novas práticas, a partir da forma como os sujeitos vivenciam a polivalência ao ponto também de problematizá-la (CURADO SILVA e CRUZ, 2015, p. 171).

Uma formação de qualidade é considerada pela Anfope como instrumento de valorização do professor, tendo em vista que essa concorre para o seu processo de 
profissionalização, estabelecendo relação com a realidade concreta em que a educação brasileira está inserida e considerando o professor como sujeito histórico.

\begin{abstract}
Um projeto de educação que reconhece o professor como um profissional que necessita ter uma sólida formação teórica e interdisciplinar sobre o fenômeno educacional e seus fundamentos históricos, políticos, filosóficos e sociais, bem como o domínio dos conteúdos a serem ensinados que permita a apropriação do processo de trabalho pedagógico, criando condições de exercer a análise crítica da sociedade brasileira e da realidade educacional (Anfope, 2004, p. 17).
\end{abstract}

Nesse processo de profissionalização, afirmamos que a formação docente numa perspectiva crítico-emancipadora corresponde a práticas formativas que se articulam com os contextos vivenciais, pessoais, profissionais, pedagógicos, organizacionais e comunitários dos atores educativos. Os professores são considerados sujeitos e não apenas objetos da formação e há um modo de conhecer do professor. O conhecer pela prática é entendido pela teoria, num movimento de unidade teoria e prática, e num processo de emancipação e autonomia docente, ou seja, o professor cria situações a partir de sua própria criatividade. Com isso, a prática, nessa perspectiva, se torna produção do conhecimento, ou seja, uma questão de natureza epistemológica, num caráter de compreensão e não de responsabilização do professor.

A formação continuada pautada numa perspectiva crítico-emancipadora, ou seja, norteada pela epistemologia da práxis, se integra ao trabalho docente, em todas as suas dimensões - políticas, sociais, culturais - e não apenas pedagógicas. Assim, a formação continuada estabelece uma relação do sujeito com o objeto para conhecer, mas não um conhecimento prático e momentâneo da epistemologia da prática, e sim, um conhecimento na dinâmica da totalidade; de compreender o trabalho docente, a função da escola, o projeto político-pedagógico e os princípios que constituem o contexto da política de formação de professores.

Para isso, a formação continuada não pode perder os elementos da formação do professor, tanto da sua formação inicial quanto de vida, considerando o docente como sujeito histórico e que deve ser discutido num processo também histórico de análise da realidade. Portanto a formação continuada deve ser pensada com sentido e proposta que esteja articulada ao projeto político pedagógico, não só da escola, mas da função e sentido da educação e da formação de novos sujeitos. 
Decorrente disso, a formação continuada deve ser trabalhada como forma de pensar a função social da educação e da escola, numa discussão política e pedagógica que envolva o coletivo e que seja entendida como ferramenta para analisar os elementos norteadores das políticas educacionais. Constrói-se, dessa maneira, segundo Curado Silva (2011), o verdadeiro sentido da práxis como ação intencional transformadora sustentada pelo conhecimento da realidade e reflexão, que pode superar o imobilismo e fortalecer o sentido histórico da ação educativa.

Por fim, a formação continuada precisa ser compreendida como política de formação docente a partir de um Sistema Nacional de Educação, num projeto de educação que articule as ações fragmentadas e desarticuladas, mas sim, de formação e valorização do sujeito docente. 


\section{CONSIDERAÇÕES FINAIS}

A pesquisa que desenvolvemos teve como objetivo analisar as concepções de formação continuada que norteiam a formação continuada desenvolvida no âmbito do Pacto Nacional pela Alfabetização na Idade Certa (Pnaic). Buscamos historicizar as concepções de formação continuada no processo de formação de professores alfabetizadores no Brasil, analisando os elementos norteadores das políticas públicas de formação para professores alfabetizadores que se consolidaram no Pnaic.

Sendo assim, para compreender melhor os elementos constitutivos da formação continuada do Pnaic, procuramos explorar fatos da realidade e entender sua fundamentação histórico-social; além das relações encontradas nos documentos oficiais e de formação, e outras interações das esferas sociais e políticas que articuladas à educação e à totalidade social, interferem e consolidam a formação docente. Isso porque decorrente de várias transformações sociais, o tema da formação continuada de professores tem sido marcado por um grande número de iniciativas e de pesquisas, que pretendem trazer à tona ora o significado da expressão "formação continuada", ora os limites e possibilidades da formação continuada no processo de desenvolvimento profissional.

Como já afirmado anteriormente, pretendemos com nossa pesquisa, contribuir para a compreensão e intervenção na formação continuada de professores alfabetizadores, construindo diálogos que articulem teoria e prática na formação; numa perspectiva de compromisso social, político e ético, voltado para uma sólida concepção teórica. Espera-se, também como produto da pesquisa, a construção de uma prática social para a investigação e intervenção nos processos de formação docente dos professores.

Considerando o levantamento no Estado do Conhecimento, percebemos que pouco têm sido a ênfase e discussão sobre o professor como trabalhador, atrelado ao seu processo histórico e emancipador de formação e valorização profissional; atravessado nas suas teorias de conhecimento e nas suas práticas pedagógicas pelos conflitos pessoais e profissionais. Assim, procuramos privilegiar em nossa pesquisa, um olhar crítico e histórico sobre a formação continuada de professores, buscando superar o antagonismo entre escola e trabalho, numa elaboração de projetos emancipatórios articulados dentro e fora da escola. 
Assim, com a investigação das concepções de formação presentes nos documentos oficiais e nos cadernos de formação do professor alfabetizador, buscamos compreender elementos da formação continuada proposta no Pnaic e que almeja formar um perfil de professor em um determinado modo de produção da existência humana.

Realizando um movimento dialético e contraditório, percebemos a partir da análise das categorias que emergem de nosso objeto de estudo, que a epistemologia da prática se constitui como concepção norteadora da formação continuada do Pnaic; sendo muitas vezes também legitimada por uma perspectiva neotecnicista, com ênfase na prática docente e no discurso da melhoria da qualidade da educação e na responsabilização do professor para alfabetizar na idade certa. Percebemos assim, que a formação continuada desenvolvida no âmbito do Pnaic tem relação com vistas a uma qualidade social da educação, numa lógica da eficiência e da eficácia. Nesse caminho dialético, a análise documental e as categorias analíticas do objeto - i) Mudança de identidade profissional docente, ii) Relação teoria e prática, iii) Professor reflexivo, iv) "Multiprofissional”, v) Responsabilização do professor e qualidade da educação, vi) Formação na perspectiva do Multiplicador, vii) Formação e valorização docente, viii) Perfil alfabetizador, xiv) Alfabetização cultural - indicaram que as concepções e práticas de formação continuada, assumidas e materializadas pela política de formação do Pnaic, aproximam-se de uma perspectiva que defende a reflexão sobre a prática pedagógica como eixo estruturante da formação dos professores alfabetizadores.

A pesquisa também revelou que a perspectiva de formação continuada do Pnaic, que valoriza a reflexão sobre a prática pedagógica envolve a figura do professor reflexivo que busca a partir da troca de experiências, reconstruir sua prática docente e assim possibilitar a melhoria dos resultados de aprendizagem de seus alunos; destacando uma lógica de práticas individuais, pragmáticas e utilitárias. Nesse contexto, o professor alfabetizador, inserido na formação continuada do Pnaic, deve ser um novo professor, um "multiprofissional", e o seu trabalho passa a ser visto como um sistema de ações concretas para resolver problemas concretos dentro da escola e da sala de aula. E nesse sentido sinalizamos algumas contradições nesse perfil alfabetizador que foram sendo apontadas na medida em que analisávamos a política de formação continuada do Pnaic.

Compreendemos também, que a formação continuada do Pnaic, mesmo considerando o caráter contraditório do seu contexto, aproximou o perfil do alfabetizador a uma perspectiva de alfabetização cultural e a importância desse 
profissional para o processo de constituição da aprendizagem da criança, bem como a necessidade da busca pelo conhecimento por parte do professor; sendo assim enfatizado, um conhecimento prático e técnico de aplicabilidade às necessidades do processo de alfabetização.

Contudo, destacamos a necessidade da formação continuada como um processo de valorização do profissional da educação que oportuniza a construção da práxis através da compreensão dos processos envolvidos na atividade educativa: intenção e ação. E que segundo Curado Silva (2016) possibilita ampliar, repensar os sentidos e significados desta prática de forma a construir uma ação consciente a partir da problematização da realidade, ampliando a autonomia do profissional e promovendo a elevação moral e intelectual dos sujeitos envolvidos.

Nessa perspectiva tomamos a epistemologia da práxis como teoria do conhecimento que pode oferecer elementos para uma proposição de formação continuada, pois tem como eixo central o conhecer na prática social do sujeito-históricoprofessor, buscando a compreensão do real e a função docente de ensinar na e para a constituição da emancipação humana.

A Associação Nacional pela Formação dos Profissionais da Educação (Anfope) é uma das entidades que vem historicamente acompanhando, questionando e se posicionando a favor da qualidade social na formação desses profissionais. Por isso a produção dessa associação é referência para os estudos e debates a respeito da política global de formação e no que diz respeito à construção de um Sistema Nacional de Educação que articula a formação e a valorização desses profissionais em todos os níveis de ensino. A luta por um projeto histórico apropriado pela categoria dos profissionais da educação em articulação com os movimentos sociais, que se contraponha ao projeto neoliberal gestado para dar conta das exigências criadas pela nova divisão internacional do trabalho é uma exigência imediata.

Ao concluirmos esta pesquisa, percebemos que há a necessidade de uma política global de formação e valorização dos profissionais da educação que contemple de forma articulada e prioritária a formação inicial, continuada e condições de trabalho, salários e carreira, com a concepção sócio-histórica do educador a orientá-la na constituição da profissão docente. Nesse sentido consideramos que a formação continuada terá valor para o professor se for estruturada como um processo evolutivo e qualitativo, contributivo do avanço profissional do professor em termos de aprendizagem, novas posturas, capacidades e autonomia. Portanto, é necessário 
investimento público massivo em políticas de profissionalização e formação continuada de professores, de qualidade elevada, para a educação básica, além de condições de infra-estrutura que ofereçam suporte para a produção de conhecimento e a formação científica adequada às demandas contemporâneas da ciência e da técnica, da cultura $\mathrm{e}$ do trabalho.

O espaço de coordenação pedagógica deve se transformar em espaço de pesquisa e estudo para tentar analisar alguns problemas da escola, extrapolando a perspectiva do modelo e do senso comum e sendo movimento de construção de possibilidades para as políticas públicas de educação. A efetivação desse espaço de formação continuada pode revelar outros caminhos e parâmetros para as políticas educacionais, possibilitando, assim, a formação, a aprendizagem e a condução do agir pedagógico se inserirem num movimento dialético para pensar a condição humana, pessoal e social dos estudantes.

Reafirmamos, assim, a necessidade de uma política global de formação e valorização dos profissionais da educação que contemple de forma articulada e prioritária a formação inicial, formação continuada e condições de trabalho, salários e carreira, com a concepção sócio-histórica do educador a orientá-la. 


\section{REFERÊNCIAS BIBLIOGÁFICAS}

ALARCÃO, Isabel (Org.). Formação reflexiva de professores: estratégias de supervisão. Porto: Porto Editora, 1996.

ALVES, Nilda. Formação de professores: pensar e fazer. São Paulo: Cortez, 2011.

APPLE, Michael. Trabalho docente e textos: economia política de classe e gênero em educação. Porto Alegre: Artmédicas, 1995.

ANFOPE. Políticas Públicas de Formação dos Profisssionais da Educação: desafios para as instituições de Ensino Superior. Documento Final do XXII Encontro Nacional. Brasília, 2004.

BRASIL. Ministério da Educação. Secretaria de Educação Básica. Próletramento: Programa de formação continuada de professores das séries iniciais do Ensino Fundamental. Formação de Professores: Fundamentos para o trabalho de tutoria - Fascículo do Tutor. Área de Alfabetização e Linguagem. Brasília: MEC/SEB, 2007.

Ministério da Educação. Secretaria de Educação Básica. Pacto Nacional pela Alfabetização na Idade Certa: formação de professores no Pacto Nacional pela Alfabetização na Idade Certa. Brasília: MEC/SEB, 2012.

Brasília, 2007.

. Plano de Desenvolvimento da Educação (PDE): Caderno de Orientações.

. Plano Nacional de Educação 2014-2024: Lei no 13.005, de 25 de junho de 2014, que aprova o Plano Nacional de Educação (PNE) e dá outras providências. Brasília: Câmara dos Deputados, Edições Câmara, 2014.

Portaria $\mathrm{n}^{\circ} 867$ de 04 de julho de 2012. Institui o Pacto Nacional pela Alfabetização na Idade Certa e as ações do PACTO e define suas diretrizes gerais. DOU de 05 de julho de 2012.

. Medida Provisória ${ }^{\circ} 586$ de 8 de novembro de 2012. Dispõe sobre o apoio técnico e financeiro da União aos entes federados no âmbito do Pacto Nacional pela Alfabetização na Idade Certa e dá outras providências. DOU de 08 de novembro de 2012.

Portaria $\mathrm{n}^{\mathrm{o}} 1458$ de 14 de dezembro de 2012. Define categorias e parâmetros para a concessão de bolsas de estudo e pesquisa no âmbito do Pacto Nacional pela Alfabetização na Idade Certa, na forma do art. 2o, inciso I, da Portaria MEC $n^{\circ} 867$, de 4 de julho de 2012. DOU de 18 de dezembro de 2012. 
Resolução n ${ }^{\circ} 4$ de 27 de fevereiro de 2013. Estabelece orientações e diretrizes para o pagamento de bolsas de estudo e pesquisa para a Formação Continuada de Professores Alfabetizadores, no âmbito do Pacto Nacional pela Alfabetização na Idade Certa. DOU de 27 de fevereiro de 2013.

. Resolução $\mathrm{n}^{\circ} 12$ de 08 de maio de 2013. Altera os dispositivos da Resolução CD/FNDE $n^{\circ} 4$ de 27 de fevereiro de 2013, que estabelece orientações e diretrizes para o pagamento de bolsas de estudo e pesquisa para a Formação Continuada de Professores Alfabetizadores, no âmbito do Pacto Nacional pela Alfabetização na Idade Certa. DOU de 08 de maio de 2013.

CONTRERAS, José. A autonomia de professores. São Paulo: Cortez, 2012.

CRUZ, Shirleide Pereira da Silva; FERREIRA, Andrea Tereza Brito. (Org.) Formação Continuada de professores: Reflexões sobre a prática. Recife: Editora Universitária da UFPE, 2010.

CUNHA, Célio da; SOUSA, José Vieira de; SILVA, Maria Abádia da. (org.). Investigação em política e gestão da educação: método, temas e olhares. Belo Horizonte: Fino Traço, 2016.

CURADO SILVA, Kátia Augusta Pinheiro Cordeiro. Articulação teoria e prática na formação de professores. Dissertação (Mestrado em Educação) - Faculdade de Educação, Universidade Federal de Goiás, Goiânia, 2001.

Kátia Augusta Pinheiro Cordeiro. Professores com formação stricto sensu e o desenvolvimento da pesquisa na educação básica da rede pública de Goiânia: realidade, entraves e possibilidades. 2008. 292f. Tese de doutorado (Programa de Pós-Graduação em Educação) - Faculdade de Educação, Universidade Federal de Goiás, Goiânia, 2008.

Kátia Augusta Curado Pinheiro Cordeiro. A formação de professores na perspectiva crítico-emancipadora. Revista Linhas Críticas-Faculdade de Educação da UnB, v.17, n³2, 2011.

.Kátia Augusta Pinheiro Cordeiro. Epistemologia da Práxis e a Formação de Professores: Perspectiva Crítica Emancipadora. (prelo). 2016

CURADO SILVA. Kátia Augusta Pinheiro Cordeiro; LIMONTA, Sandra Valéria. Formação de professores, trabalho docente e qualidade do ensino. In: LIBÂNEO, José Carlos; SUANNO, Marilza Vanessa Rosa; LIMONTA, Sandra Valéria (Orgs). Qualidade da escola pública: políticas educacionais, didática e formação de professores. Goiânia: CEPED, 2013.

CURADO SILVA. Kátia Augusta Pinheiro Cordeiro; LIMONTA, Sandra Valéria. Formação de professores em uma perspectiva crítico-emancipadora: a materialidade 
da utopia. In: CURADO SILVA, K.A.P.C.da; LIMONTA, S.V. (Org.) Formação de professores na perspectiva crítica: resistência e utopia. Brasília: Editora Universidade de Brasília, 2014.

CURADO SILVA, Kátia Augusta Pinheiro Cordeiro; CRUZ, Shirleide Pereira da Silva. O professor polivalente dos anos iniciais do Ensino Fundamental. In: SILVA, Carlos Cardoso; LIMONTA, Sandra Valéria (Org.) Anos Iniciais do Ensino Fundamental Política, Gestão, Formação de Professores e Ensino. Campinas, SP: Mercado de Letras, 2015.

CURY, Carlos Roberto Jamil. Educação e Contradição: elementos metodológicos para uma teoria crítica do fenômeno educativo. São Paulo: Cortêz, 1987.

DALBEN, Ângela Imaculada Loureiro de Freitas; GOMES, Maria de Fátima Cardoso. (Org.) Formação Continuada de Docentes da Educação Básica. Belo Horizonte: Autêntica Editora, 2009.

DEWEY, John. Democracia e educação. São Paulo: Companhia Editora Nacional, 1979.

DOURADO, Luiz Fernandes. (Org.) Políticas e Gestão da Educação no Brasil novos marcos regulatórios? São Paulo: Xamã, 2009.

FERREIRA, Naura Syria Carapeto Ferreira. (Org.) Formação continuada e gestão da Educação. São Paulo: Cortez, 2003.

FREITAS, Helena C. L. de. A (nova) política de formação de professores: a prioridade postergada. In: Educação e Sociedade. Campinas, vol. 28, n.100. - Especial, p. 12031230, out. 2007.

FREITAS, Luiz Carlos de. Neotecnicismo e Formação do Educador. In: ALVES, Nilda (org.). Formação de professores: pensar e fazer. São Paulo: Cortez, 1992.

. Luiz Carlos de. Ciclos, seriação e avaliação: confronto de lógicas. São

Paulo: Moderna, 2003.

FRIGOTTTO, Gaudêncio. O enfoque da dialética materialista histórica na pesquisa educacional. In: FAZENDA, I. Metodologia da Pesquisa Educacional. $12^{a}$ ed. São Paulo: Cortez, 2001.

GADOTTI, Moacir. Pedagogia da Práxis. São Paulo: Cortez, Instituto Paulo Freire, 2010 . 
GAMBOA, Silvio Ancízar Sanchez. A dialética na pesquisa em educação: elementos de contexto. In: FAZENDA, I. Metodologia da Pesquisa Educacional. $12^{\mathrm{a}}$ ed. São Paulo: Cortez, 2001.

Silvio Ancízar Sanchez. Pesquisa em Educação: métodos e epistemologias. Chapecó: Argos, 2008.

GARCIA, Regina Leite. (Org.) A formação da professora alfabetizadora: reflexões sobre a prática. São Paulo: Cotez, 2003.

GATTI, Bernadete Angelina, BARRETO, Elba e ANDRÉ, Marli Eliza Afonso. Políticas docentes no Brasil: um estado da arte. Brasília: UNESCO, 2011.

GHEDIN, Evandro. Professor reflexivo: da alienação da técnica à autonomia da crítica. In: PIMENTA, Selma Garrido; GHEDIN, Evandro. Professor Reflexivo no Brasil: gênese e crítica de um conceito. São Paulo: Cortez, 2012.

GIROUX, Henry. Os professores como intelectuais: rumo a uma pedagogia crítica. Porto Alegre: Artes Médicas, 1997.

GONTIJO, Cláudia Maria Mendes. Alfabetização - políticas mundiais e movimentos nacionais. Campinas: Autores Associados, 2014.

GRAMSCI, Antonio. Concepção dialética da história. Rio de Janeiro: Civilização Brasileira, 1966.

KOSIK, Karel. Dialética do Concreto. Rio de Janeiro: Paz e Terra, 1986.

LAMY, Gersolina Antonia de Avelar; HOELLER, Solange A. de Oliveira (org.). Alfabetização em destaque. Campinas: Mercado de Letras, 2010.

LIBÂNEO, José Carlos. Reflexividade e formação de professores: outra oscilação do pensamento pedagógico brasileiro? In: PIMENTA, Selma Garrido; GHEDIN, Evandro. Professor Reflexivo no Brasil: gênese e crítica de um conceito. São Paulo: Cortez, 2012.

LIMA, Kátia Regina de Souza; MARTINS, André Silva. Pressupostos, princípios e estratégias. In: NEVES, L.M.W. A nova pedagogia da hegemonia: estratégias do capital para educar o consenso. São Paulo: Xamã, 2005.

LIMONTA, Sandra Valéria; SILVA, Carlos Cardoso. (Org.) Anos Iniciais do Ensino Fundamental: política, gestão, formação de professores e ensino. Campinas: Mercado de Letras, 2015.

MARTINS, André Silva; NEVES, Lúcia M. Wanderley. A nova pedagogia da hegemonia e a formação/atuação de seus intelectuais orgânicos. In: NEVES, L.M.W. 
(org.) Direita para o social e esquerda para o capital. Intelectuais da pedagogia no Brasil. São Paulo: Xamã, 2010.

MARX, Karl; ENGELS, Friedrich. A ideologia alemã. São Paulo: Boitempo, 2007. Karl. Manuscritos econômico-filosóficos e outros textos escolhidos. São Paulo, Abril Cultural (Os pensadores), 1978. . Karl. O Capital - Volume I. Rio de Janeiro: Civilização Brasileira, 1982. Karl. Contribuição para a crítica da economia política. São Paulo: Expressão Popular, 2008.

MASCARENHAS, Angela Cristina Belém. A contribuição do materialismo históricodialético para a análise das políticas educacionais. In: CUNHA, Célio da; SOUSA, José Vieira de; SILVA, Maria Abádia da. (org.) O método dialético na pesquisa em educação. Campinas: Autores Associados, 2014.

MCNALLY, J. Língua, história e luta de classe. In: WOOD, E. M.; FOSTER, J. B. Em defesa da história. Marxismo e pós-modernismo. Rio de Janeiro: Jorge Zahar Editora, 1999.

MELO, Adriana Almeida Sales de Melo. A mundialização da educação. Consolidação do projeto neoliberal na América Latina - Brasil e Venezuela. Maceió: Edufal, 2004.

MORTATTI, Maria do Rosário Longo. (Org.) Formação de professores: propostas para ação no ensino fundamental e médio. São Paulo: JM Editora, 2003.

. Maria do Rosário Longo. (Org.) Alfabetização no Brasil: uma história de sua história. São Paulo: Cultura Acadêmica, 2011.

NETTO, J. P. Introdução ao estudo do método de Marx. 1 ${ }^{a}$. ed. São Paulo: Expressão Popular, 2011.

NORONHA, Olinda Maria. Epistemologia, formação de professores e práxis educativa transformadora. In: Revista QUAESTIO, Sorocaba, 2010, v. 12, p. 5-24.

NÓVOA, António. (org.) Os professores e sua formação. 3 ed. Lisboa: Dom Quixote, 1997.

PALUDO, Conceição; VITÓRIA, Fernando Bilhalva. Contribuições do materialismo histórico-dialético para o entendimento da política pública social na atualidade. In: CUNHA, Célio da; SOUSA, José Vieira de; SILVA, Maria Abádia da. (org.) O método dialético na pesquisa em educação. Campinas: Autores Associados, 2014. 
PIMENTA, Selma Garrido. Professor reflexivo: construindo uma crítica. In: PIMENTA, Selma Garrido; GHEDIN, Evandro. Professor Reflexivo no Brasil: gênese e crítica de um conceito. São Paulo: Cortez, 2012.

OLIVEIRA, Dalila Andrade; PINI, Mónica Eva; FELDFEBER, Myriam. (Org.) Políticas Educacionais e Trabalho Docente: perspectiva comparada. Belo Horizonte: Fino Traço, 2011.

OLIVEIRA, Dalila Andrade. A reestruturação do trabalho docente: precarização e flexibilização. In: Revista Educação \& Sociedade, Campinas, vol. 25, nº 89, p. 1127 1144, set./dez, 2004.

OLIVEIRA, Daniela Motta de. (Org.) Formação Continuada: contribuições para o debate. Juiz de Fora: Editora UFJF, 2012.

RÊSES, Erlando da Silva. De vocação para profissão: sindicalismo docente da educação básica no Brasil. Brasília: Editora Paralelo 15, 2015.

SACRISTÁN, J. Gimeno. Consciência e Acção sobre a prática como libertação profissional dos Professores. In: NÓVOA, António (org.). Profissão professor. Porto: Porto Editora, 1995.

J. Gimeno. Reformas Educacionais: utopia, retórica e prática. In: SILVA, Tomaz Tadeu da; GENTILI., Pablo (orgs.). Escola S.A. quem ganha e quem perde no mercado educacional do Neoliberalismo. Brasília: CNTE, 1996

SANTOS, Edlamar Oliveira dos. A Formação continuada na rede de ensino do Recife: concepções e práticas de uma política em construção. Recife: PPGE/UFPE, 2010.

. Edlamar Oliveira dos. Políticas e Práticas de Formação Continuada de Professores da Educação Básica. Jundiaí: Paco Editorial, 2014.

SAVIANI, Dermeval. História da formação docente no Brasil: três momentos decisivos. Revista Educação. Rio Grande do Sul, v. 30, n. 2, 2005.

SCHÖN, Donald. Educando o profissional reflexivo: um novo design para o ensino e a aprendizagem. Porto Alegre: Artes Médicas, 2000.

SHIROMA, Eneida Oto; MORAES, Maria Célia Marcondes; EVANGELISTA, Olinda. Política Educacional. Rio de Janeiro: Lamparina, 2007.

SHIROMA, E. O.; CAMPOS, R. F.; GARCIA, R. M. C. Decifrar textos para compreender a política: subsídios teórico-metodológicos para análise de documentos. Perspectiva, Florianópolis, v. 23, n. 02, jul./dez. 2005. 
SOARES, Magda Becker. Alfabetização e letramento. São Paulo: Contexto, 2003.

TARDIF, Maurice. Saberes docentes e formação profissional. Petrópolis-RJ: Vozes, 2002.

THOMPSON, E. P. A miséria da teoria ou um planetário de erros. Uma crítica ao pensamento de Althusser. Rio de Janeiro: Zahar Editora, 1981.

TRIVIÑOS, A. N. S. Introdução à pesquisa em Ciências Sociais. São Paulo: Atlas, 2013.

VASQUEZ, Adolfo Sanches. Filosofia da Práxis. Rio de Janeiro: Paz e Terra, 1968.

ZEICKNER, Kenneth. A Formação reflexiva de professores: ideias e práticas. Lisboa, Portugal: Educa, 1993.

Para além da divisão entre professor-pesquisador e professor acadêmico. In: GERALDJ, Corinta M G, FIORENTINI, Dario, e PEREIRA, Elisabete M de A. Cartografias do trabalho docente. Campinas: Mercado das Letras, 1998. 


\section{APÊNDICE}

\section{QUADRO 6 - EIXOS DE ANÁLISE, PRÉ-INDICADORES E INDICADORES}

\begin{tabular}{|c|c|c|}
\hline EIXOS & PRÉ-INDICADORES & INDICADORES \\
\hline $\begin{array}{c}\text { Papel/Função da } \\
\text { Formação Continuada }\end{array}$ & $\begin{array}{l}\text { * Muitas vezes, a formação está } \\
\text { inserida em um discurso } \\
\text { institucional que, a partir de } \\
\text { diversos interesses, obriga o } \\
\text { professor a participar de } \\
\text { Programas de estudo que } \\
\text { intentam fazer com que ele se } \\
\text { desenvolva profissionalmente, } \\
\text { no sentido de melhorar seu } \\
\text { desempenho na sala de aula e, } \\
\text { sobretudo, de melhorar a } \\
\text { aprendizagem dos seus alunos. } \\
\text { (Caderno de Formação Pnaic } \\
\text { 2013) } \\
\text { * Na formação continuada, } \\
\text { portanto, é necessário investir } \\
\text { na construção positiva da } \\
\text { identidade profissional coletiva, } \\
\text { reforçando a importância e a } \\
\text { responsabilidade } \\
\text { atividade no contexto social. } \\
\text { (Caderno de Formação Pnaic } \\
\text { - Aça) } \\
\text { * Oss princípios da formação } \\
\text { continuada que orientam as } \\
\text { ações do PACTO, explicitadas } \\
\text { nos cadernos de linguagem são: } \\
\text { - A rática da reflexividade: }\end{array}$ & $\begin{array}{l}1 \text { - Identidade do "ser professor" } \\
\text { (individual e/ou coletiva). }\end{array}$ \\
\hline
\end{tabular}




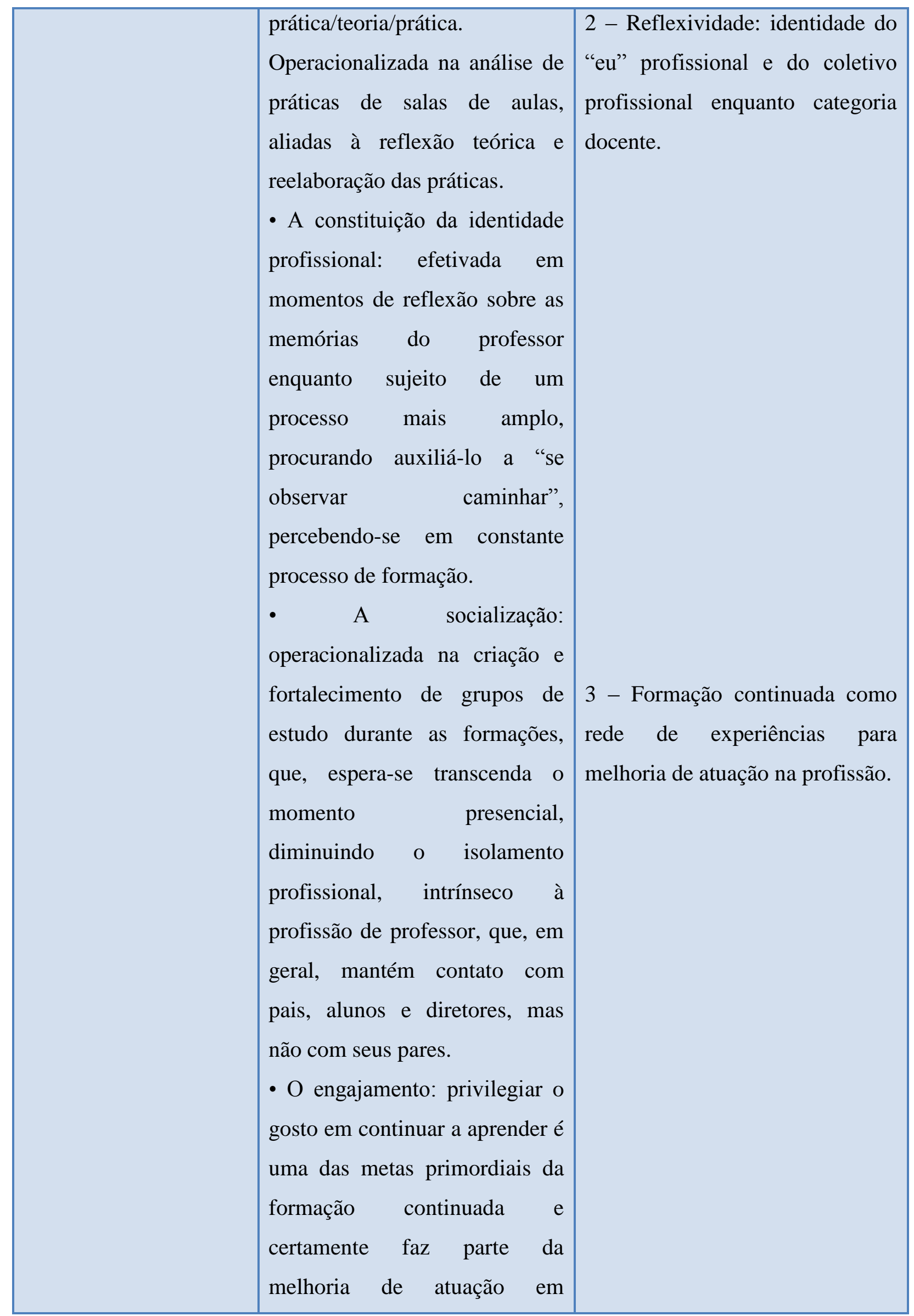




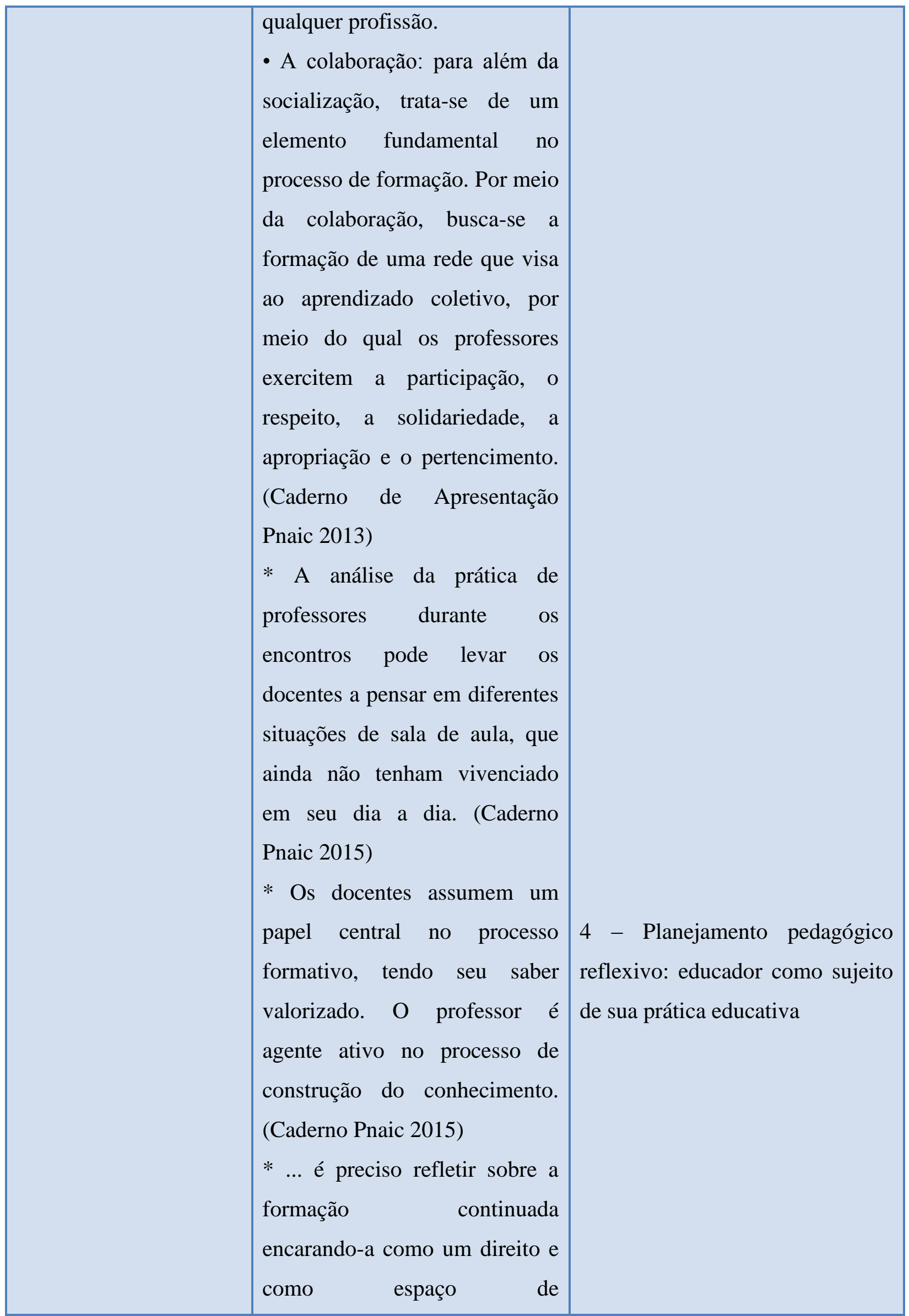




\begin{tabular}{|c|c|c|}
\hline & $\begin{array}{l}\text { problematização, socialização e } \\
\text { construção de saberes (Caderno } \\
\text { Pnaic 2015) } \\
\text { * Por isso é fundamental } \\
\text { assegurar uma formação inicial } \\
\text { e continuada que valorize a } \\
\text { trajetória profissional, mas que } \\
\text { torne esta etapa de ensino mais } \\
\text { atrativa para os professores, } \\
\text { assegurando as condições } \\
\text { necessárias para que eles } \\
\text { desempenhem seu trabalho com } \\
\text { competência e entusiasmo. } \\
\text { (Manual do Pnaic - livreto) } \\
\text { * A formação continuada dos } \\
\text { professores alfabetizadores } \\
\text { precisa garantir, dentre outros } \\
\text { aspectos, as ferramentas para } \\
\text { alfabetizar com planejamento. } \\
\text { A formação precisa garantir } \\
\text { ainda o aprofundamento dos } \\
\text { conhecimentos } \\
\text { alfabetização, } \\
\text { interdisciplinaridade e inclusão } \\
\text { como princípio fundamental do } \\
\text { Processo educativo. (Manual do } \\
\text { Pnreto) }\end{array}$ & $\begin{array}{l}5 \text { - Formação continuada e } \\
\text { valorização profissional }\end{array}$ \\
\hline $\begin{array}{c}\text { Função/Papel do } \\
\text { professor }\end{array}$ & $\begin{array}{l}\text { * O professor alfabetizador tem } \\
\text { a função de auxiliar na } \\
\text { formação para o bom exercício } \\
\text { da cidadania. Para exercer sua } \\
\text { função de forma plena é preciso } \\
\text { ter clareza do que ensina e }\end{array}$ & $\begin{array}{l}1 \text { - O professor deve formar para } \\
\text { a cidadania e saber o que ensinar } \\
\text { e como ensinar. }\end{array}$ \\
\hline
\end{tabular}




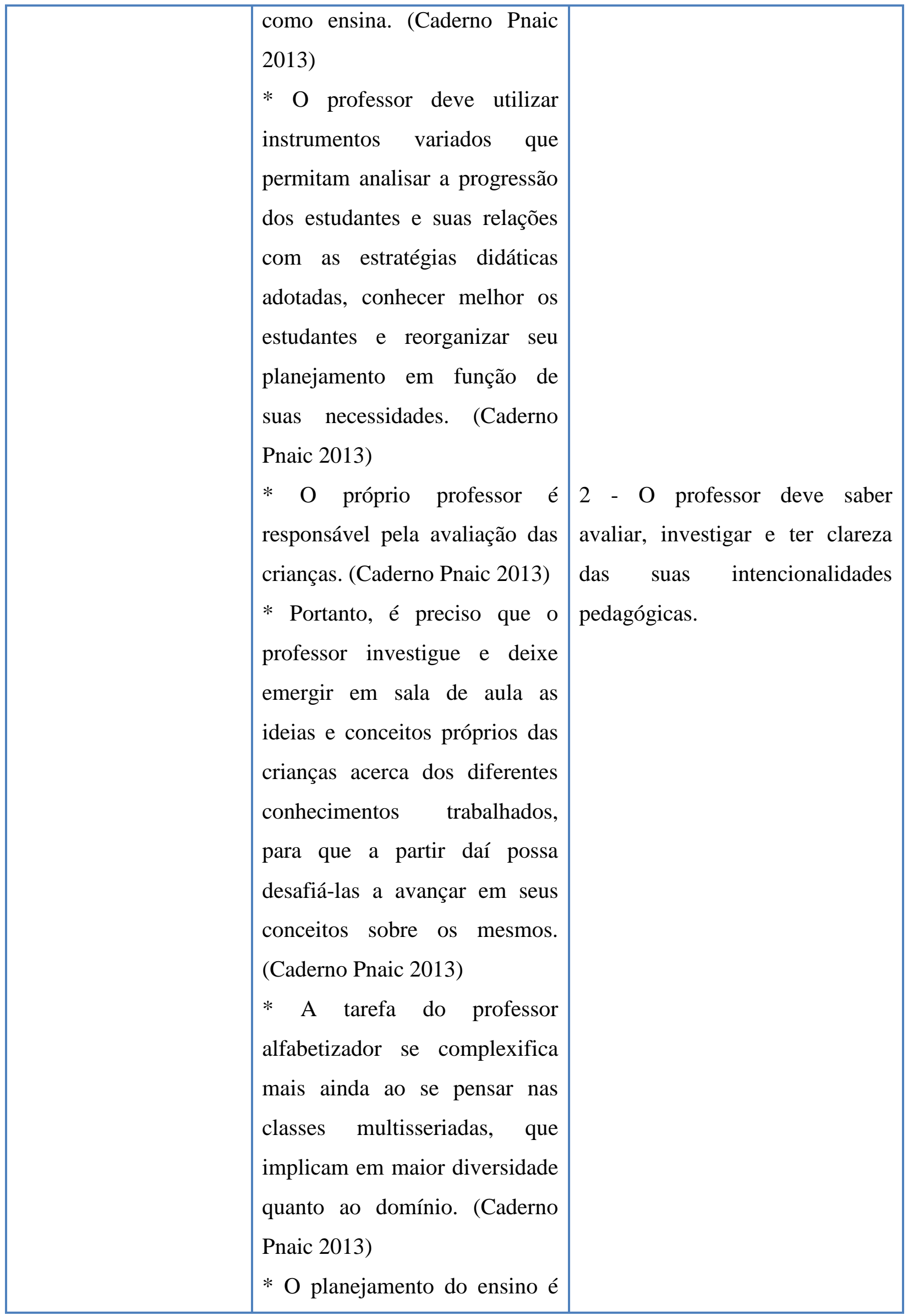




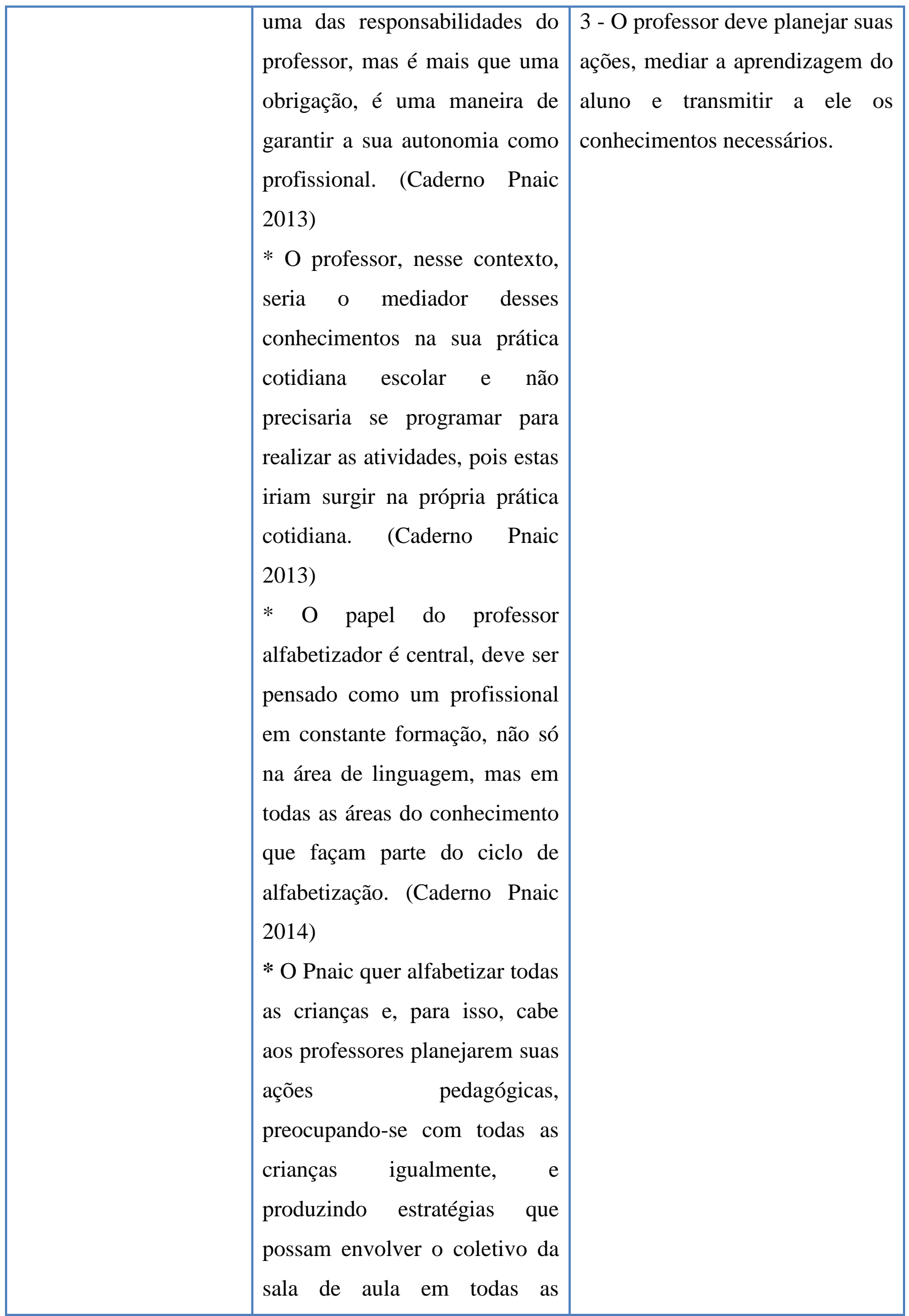




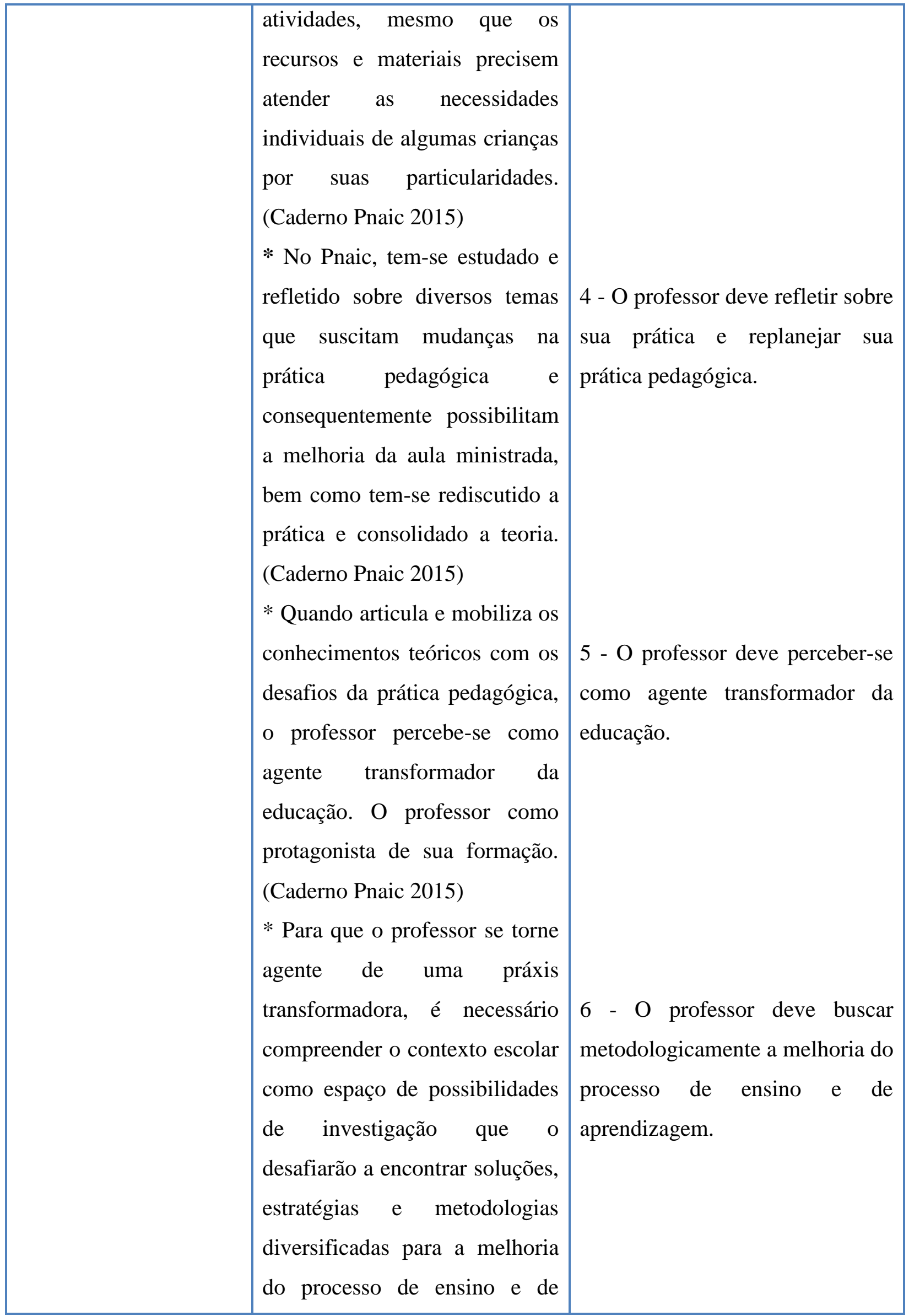




\begin{tabular}{|c|c|c|}
\hline & $\begin{array}{l}\text { aprendizagem. } \\
\text { (Caderno Pnaic 2015) }\end{array}$ & \\
\hline $\begin{array}{l}\text { Modelo estruturante } \\
\text { do Pnaic }\end{array}$ & $\begin{array}{l}\text { * Formação continuada } \\
\text { presencial para os professores } \\
\text { alfabetizadores e seus } \\
\text { orientadores de estudo, cuja } \\
\text { metodologia propõe estudos e } \\
\text { atividades práticas. (Caderno de } \\
\text { Apresentação do Pnaic 2013) } \\
\text { * A formação no âmbito deste } \\
\text { programa é focada na prática do } \\
\text { professor, de modo que as } \\
\text { singularidades do trabalho } \\
\text { pedagógico são objeto de } \\
\text { reflexão. Refletir, estruturar e } \\
\text { melhorar a ação docente é, } \\
\text { portanto, o principal objetivo da } \\
\text { formação. A mobilização dos } \\
\text { saberes docentes é, também, } \\
\text { outro ponto central no debate } \\
\text { dessa formação continuada. } \\
\text { (Caderno de Apresentação do } \\
\text { Pnaic 2013) } \\
\text { * Os orientadores de estudo são } \\
\text { professores da Rede Nacional } \\
\text { de Formação Continuada de } \\
\text { Professores da Educação Básica } \\
\text { em parceria com as } \\
\text { Universidades e Fundações de } \\
\text { Pesquisas. (Caderno de } \\
\text { Apresentação do Pnaic } 2013 \text { ) } \\
\text { * Oito cadernos para cada curso } \\
\text { - } 1^{\circ}, 2^{\circ}, 3^{\circ} \text { anos e Educação do }\end{array}$ & $\begin{array}{l}2 \text { - Formação continuada } \\
\text { organizada em formato de rede } \\
\text { multiplicadora e estrutura } \\
\text { hierárquica. } \\
3 \text { - Formação continuada e }\end{array}$ \\
\hline
\end{tabular}




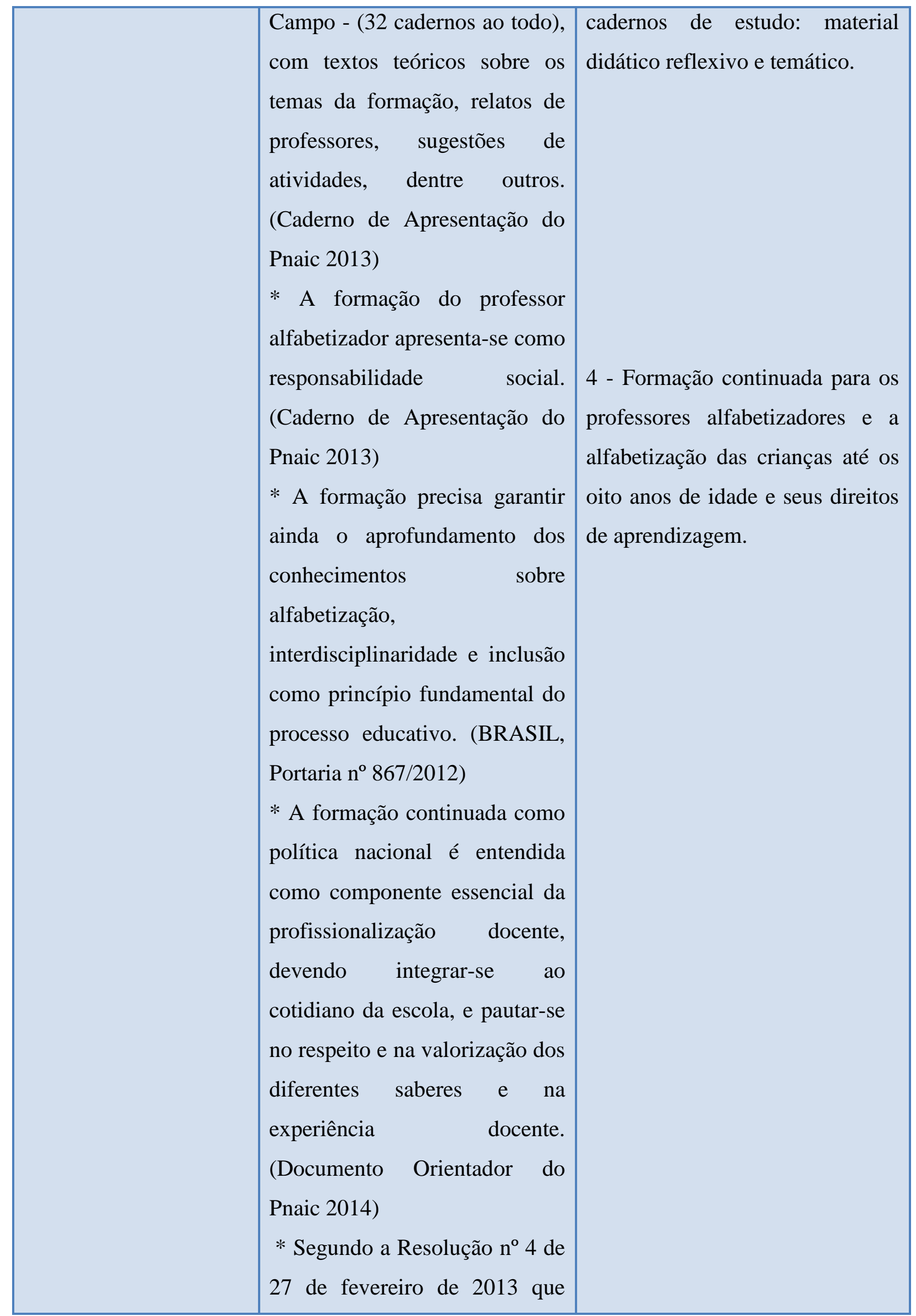




\begin{tabular}{|c|c|c|}
\hline & $\begin{array}{l}\text { estabelece orientações } \\
\text { diretrizes para o pagamento de } \\
\text { bolsas de estudo e pesquisa } \\
\text { para a formação continuada de } \\
\text { professores alfabetizadores, no } \\
\text { âmbito do pacto nacional pela } \\
\text { alfabetização na idade. }\end{array}$ & $\begin{array}{l}5 \text { - Formação continuada e o } \\
\text { pagamento de bolsas de estudo } \\
\text { para os } \\
\text { alfabetizadores e os orientadores } \\
\text { de estudo. }\end{array}$ \\
\hline $\begin{array}{l}\text { Concepções de } \\
\text { alfabetização }\end{array}$ & $\begin{array}{l}\text { * perspectiva assumida, } \\
\text { portanto, é de uma } \\
\text { alfabetização viva, em que as } \\
\text { crianças se apropriem da leitura } \\
\text { e da escrita de modo ativo, } \\
\text { agindo socialmente: ler e } \\
\text { escrever para interlocutores que } \\
\text { assumem diferentes papéis } \\
\text { sociais, e não apenas para o } \\
\text { professor, para atender a } \\
\text { diferentes propósitos, } \\
\text { contextualmente situados. } \\
\text { (Cadernos Pnaic 2013) } \\
\text { * É ressaltado que ser } \\
\text { alfabetizado é muito mais do } \\
\text { que dominar apenas os } \\
\text { rudimentos da leitura e escrita, } \\
\text { mesmo sendo capaz de ler e } \\
\text { escrever todas as palavras. A } \\
\text { pessoa alfabetizada é aquela } \\
\text { que é capaz de ler e escrever em } \\
\text { diferentes situações sociais, de } \\
\text { tal forma que isso lhe permita } \\
\text { inserir-se e participar } \\
\text { ativamente de um mundo } \\
\text { letrado, enfrentando os desafios }\end{array}$ & $\begin{array}{l}1 \text { - Alfabetização viva, ativa, } \\
\text { social, num contexto linguístico e } \\
\text { matemático. }\end{array}$ \\
\hline
\end{tabular}




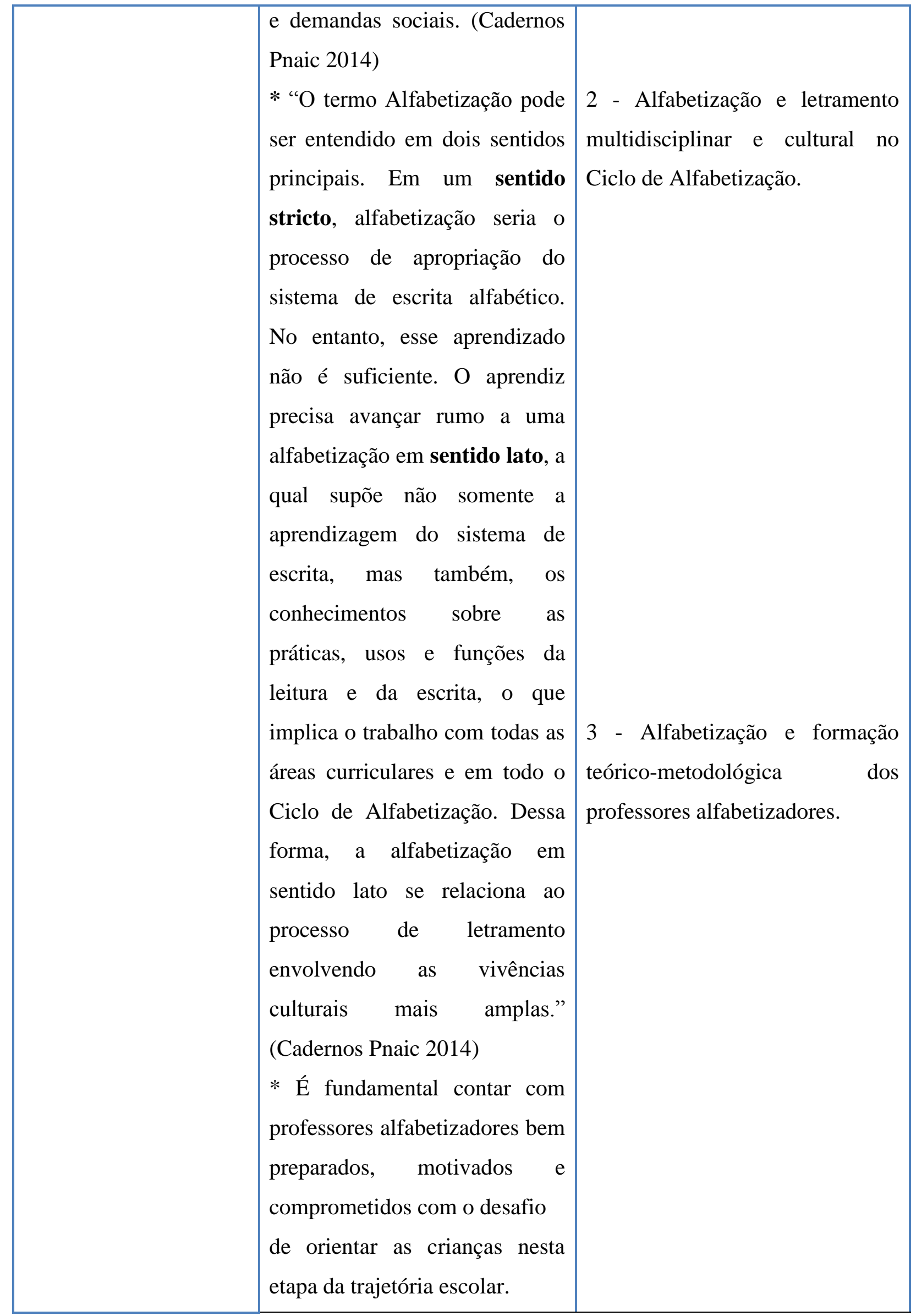




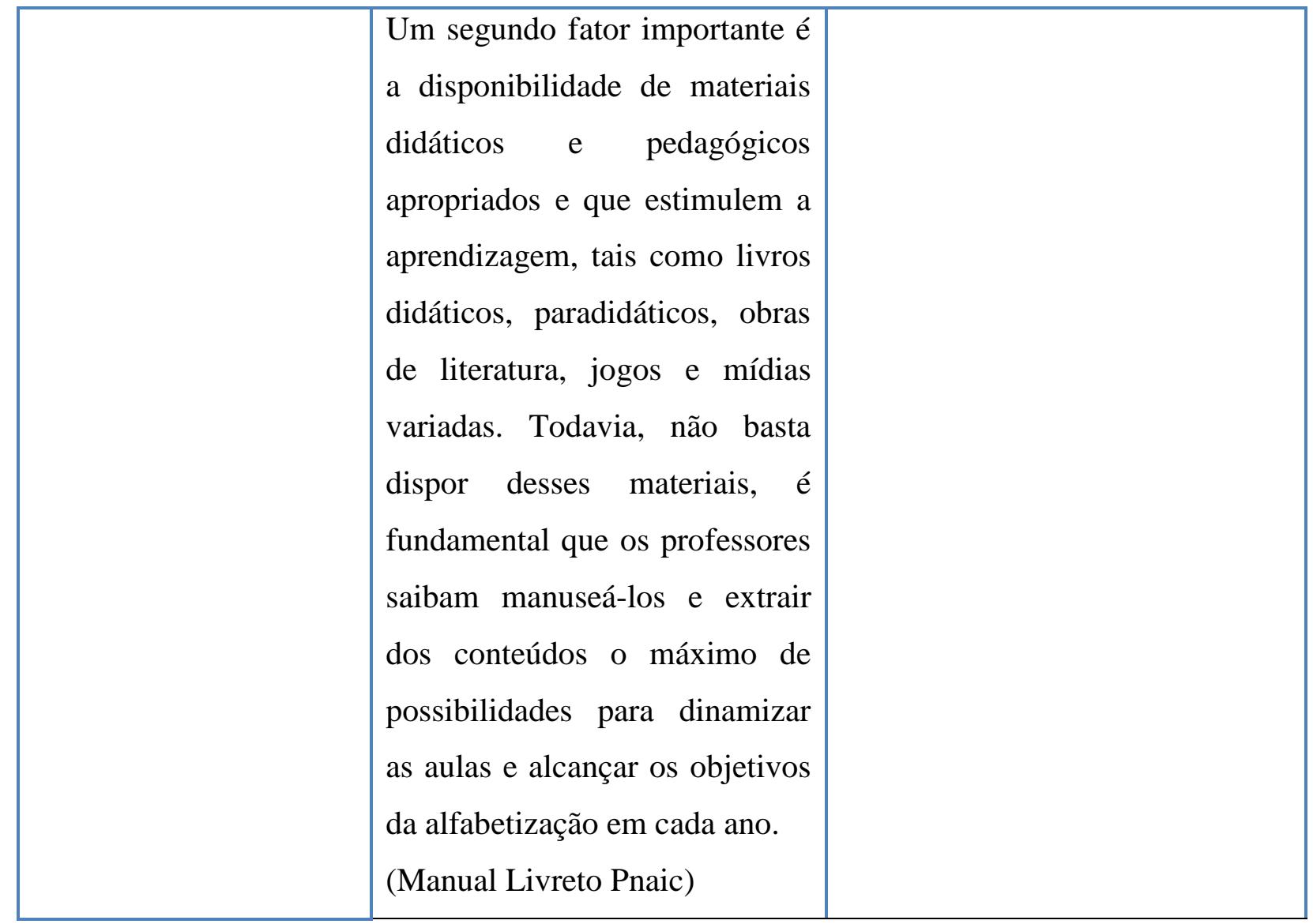

Fonte: Elaborado pela pesquisadora a partir da análise dos Documentos do Pnaic em junho de 2016. 
QUADRO 7 - EIXOS DE ANÁLISE, INDICADORES E CATEGORIAS DO OBJETO

\begin{tabular}{|c|c|c|}
\hline EIXOS & INDICADORES & CATEGORIAS \\
\hline $\begin{array}{l}\text { Papel da Formação } \\
\text { Continuada }\end{array}$ & $\begin{array}{l}1 \text { - Identidade do "ser } \\
\text { professor" (individual e/ou } \\
\text { coletiva). } \\
2 \quad-\quad \text { Reflexividade: } \\
\text { identidade do "eu" } \\
\text { profissional e do coletivo } \\
\text { profissional enquanto } \\
\text { categoria docente. } \\
3 \text { - Formação continuada } \\
\text { como rede de experiências } \\
\text { para melhoria de atuação } \\
\text { na profissão. } \\
\text { vedagógica. } \\
\text { valorização profissional. } \\
\text { pedagógico reflexivo: } \\
\text { educador como sujeito de } \\
\text { sua prática educativa. } \\
\text { - Formação continuada e } \\
\text { instrumentalização } \\
\text { - }\end{array}$ & $\begin{array}{l}1 \text { - Mudança de identidade } \\
\text { profissional docente } \\
2 \text { - Formação e valorização } \\
\text { docente }\end{array}$ \\
\hline $\begin{array}{c}\text { Função/Papel do } \\
\text { professor }\end{array}$ & $\begin{array}{l}1-\text { O professor deve } \\
\text { formar para a cidadania e } \\
\text { saber o que ensinar e como } \\
\text { ensinar. }\end{array}$ & $\begin{array}{l}1 \text { - "Multiprofissional" } \\
2 \text { - Responsabilização do } \\
\text { professor e qualidade da } \\
\text { educação. }\end{array}$ \\
\hline
\end{tabular}




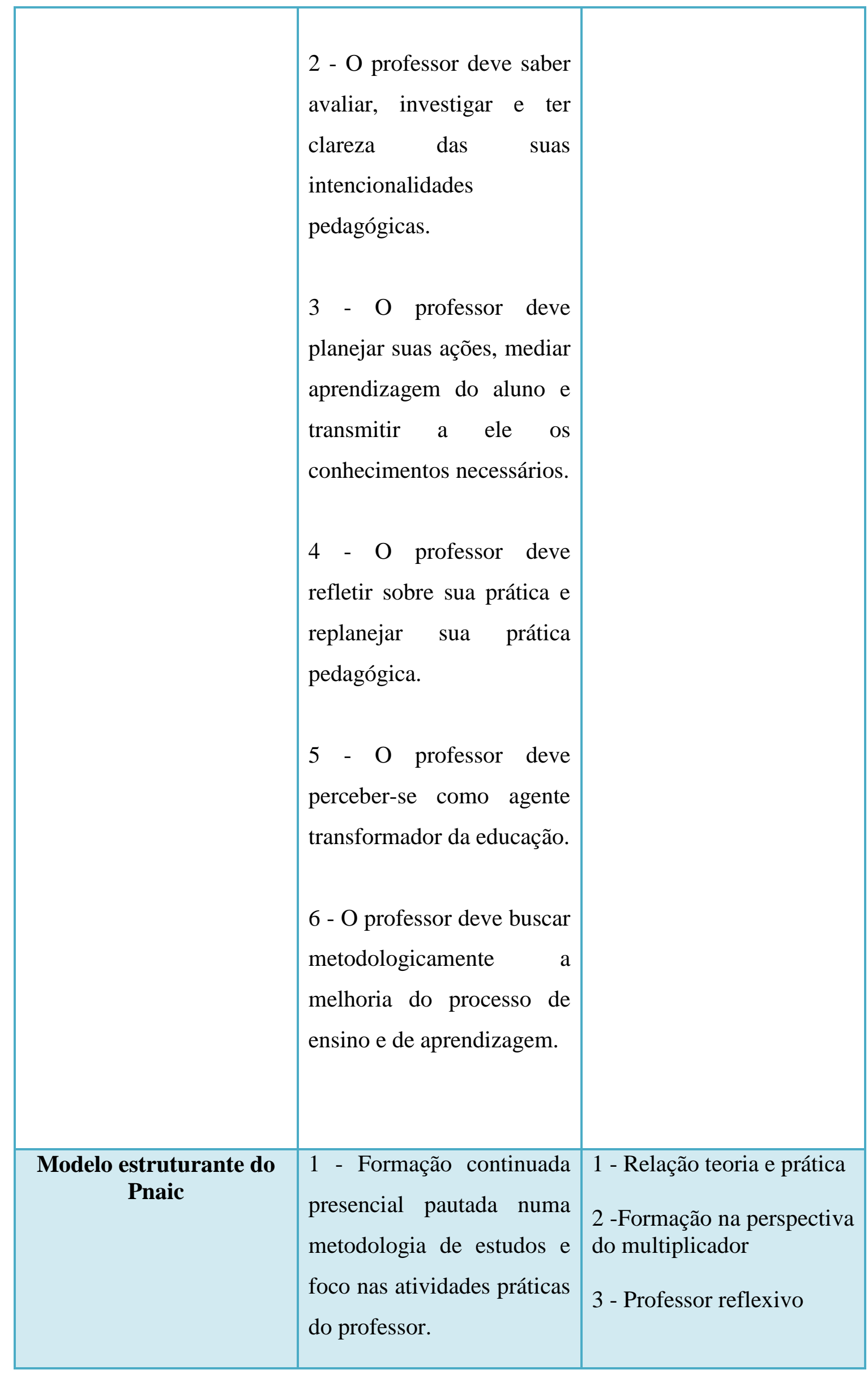




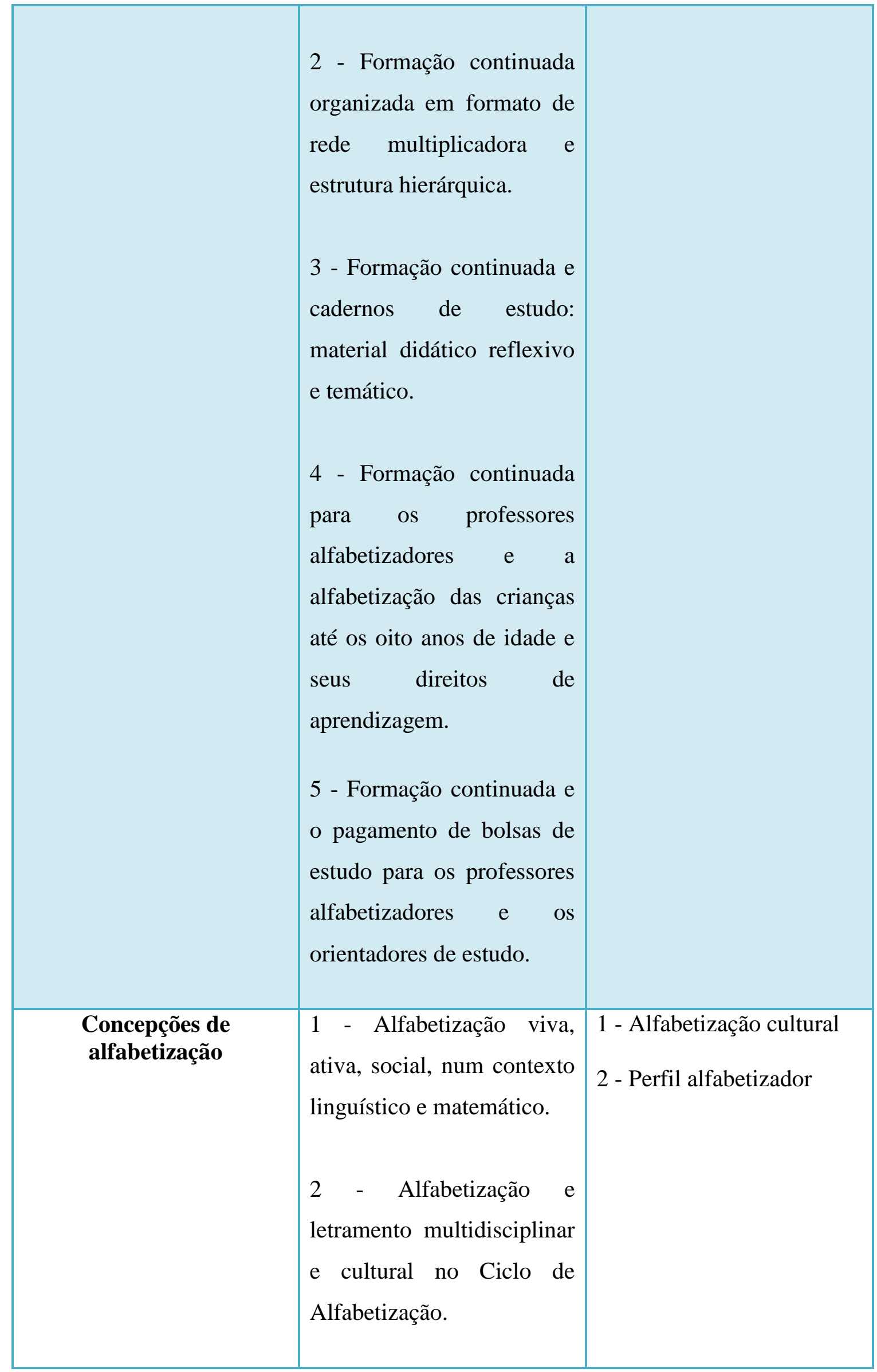




\begin{tabular}{|l|lr|l|}
\hline & - Alfabetização e & \\
formação & teórico- & \\
metodológicar r dos & & \\
professores & & \\
alfabetizadores. & & \\
\hline
\end{tabular}

Fonte: Elaborado pela pesquisadora a partir da análise dos Documentos do Pnaic em junho de 2016. 
QUADRO 8 - REFERÊNCIAS AUTORAIS E TEÓRICAS - Pnaic

\begin{tabular}{|c|c|c|}
\hline $\begin{array}{l}\text { TEMÁTICAS DE } \\
\text { ESTUDO }\end{array}$ & $\begin{array}{c}\text { AUTORES } \\
\text { REFERENCIADOS }\end{array}$ & ABORDAGEM TEÓRICA \\
\hline \multirow{6}{*}{$\begin{array}{c}\text { Alfabetização e o } \\
\text { ensino da língua } \\
\text { materna }\end{array}$} & $\begin{array}{l}\text { Emilia Ferreiro e Ana } \\
\text { Teberosky }\end{array}$ & $\begin{array}{l}\text { Hipóteses sobre como } \\
\text { funciona o processo de } \\
\text { elaboração da escrita. }\end{array}$ \\
\hline & $\begin{array}{l}\text { Telma Ferraz Leal e Ana } \\
\text { Carolina Brandão }\end{array}$ & $\begin{array}{l}\text { Práticas sociais da escrita e } \\
\text { ampliação da oralidade. } \\
\text { Importância da ludicidade e } \\
\text { da literatura na alfabetização. }\end{array}$ \\
\hline & Magda Soares & $\begin{array}{l}\text { Alfabetização na perspectiva } \\
\text { do letramento. }\end{array}$ \\
\hline & $\begin{array}{l}\text { Angela Kleiman e Sílvia } \\
\text { Moraes }\end{array}$ & $\begin{array}{l}\text { Consolidação e ampliação da } \\
\text { leitura por um processo de } \\
\text { integração de conhecimentos, } \\
\text { no qual o professor é o } \\
\text { mediador. }\end{array}$ \\
\hline & Piaget & $\begin{array}{l}\text { Desenvolvimento da criança a } \\
\text { partir de sua maturação e } \\
\text { estimulação do ambiente físico. }\end{array}$ \\
\hline & Piaget e Bakhtin & $\begin{array}{l}\text { Destacam o papel da interação } \\
\text { do aprendiz com o outro no } \\
\text { processo de aprendizagem e a } \\
\text { dimensão da cultura nessa } \\
\text { interação. Os gêneros textuais } \\
\text { fazem parte do contexto social } \\
\text { do discurso. }\end{array}$ \\
\hline
\end{tabular}




\begin{tabular}{|c|c|c|}
\hline & $\begin{array}{l}\text { Artur Gomes de Morais e } \\
\text { Eliana Borges Albuquerque }\end{array}$ & $\begin{array}{l}\text { Importância das interações } \\
\text { sociais e papel fundante da } \\
\text { linguagem no desenvolvimento } \\
\text { cognitivo do ser humano. } \\
\text { Além de inserir o aluno nas } \\
\text { situações de letramento, é } \\
\text { necessário levá-lo a refletir } \\
\text { sobre os princípios do Sistema } \\
\text { de Escrita Alfabética (SEA). } \\
\text { Nesse sentido esses referidos } \\
\text { autores sugerem alguns } \\
\text { princípios que constituem o } \\
\text { SEA e que necessitam ser } \\
\text { compreendidos/dominados } \\
\text { pelas crianças para que elas se } \\
\text { apropriem da escrita; e esses } \\
\text { princípios são desenvolvidos } \\
\text { por estratégias de trabalho } \\
\text { docente. }\end{array}$ \\
\hline $\begin{array}{l}\text { Alfabetização e os } \\
\text { gêneros textuais }\end{array}$ & $\begin{array}{l}\text { Bernard Schneuwly } \\
\text { Joaquim Dolz }\end{array}$ & $\begin{array}{l}\text { Proposta de progressão e } \\
\text { aprofundamento dos gêneros } \\
\text { textuais a serem trabalhados } \\
\text { com o passar dos anos/ciclos, } \\
\text { numa abordagem cada vez } \\
\text { mais complexa. Para realizar } \\
\text { esse trabalho progressivo com } \\
\text { os gêneros, o professor } \\
\text { alfabetizador precisa conhecer } \\
\text { bem quais habilidades os seus } \\
\text { alunos já possuem e } \\
\text { estabelecer quais são aquelas } \\
\text { almejadas. }\end{array}$ \\
\hline
\end{tabular}




\begin{tabular}{|c|c|c|}
\hline $\begin{array}{c}\text { Alfabetização e } \\
\text { letramento } \\
\text { matemático }\end{array}$ & $\begin{array}{l}\text { Carlos Roberto Viana e } \\
\text { Emerson Rolkouski }\end{array}$ & 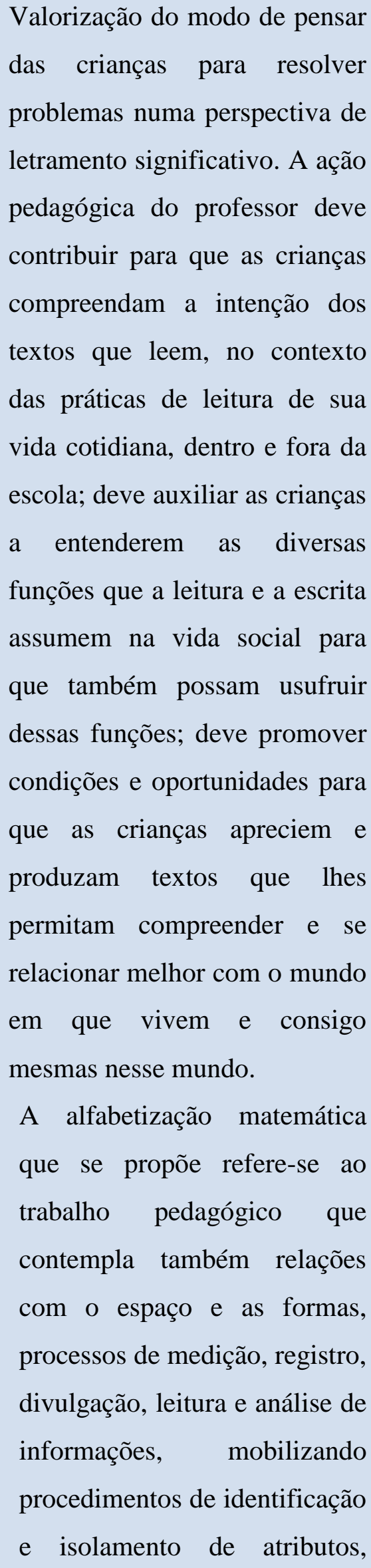 \\
\hline
\end{tabular}




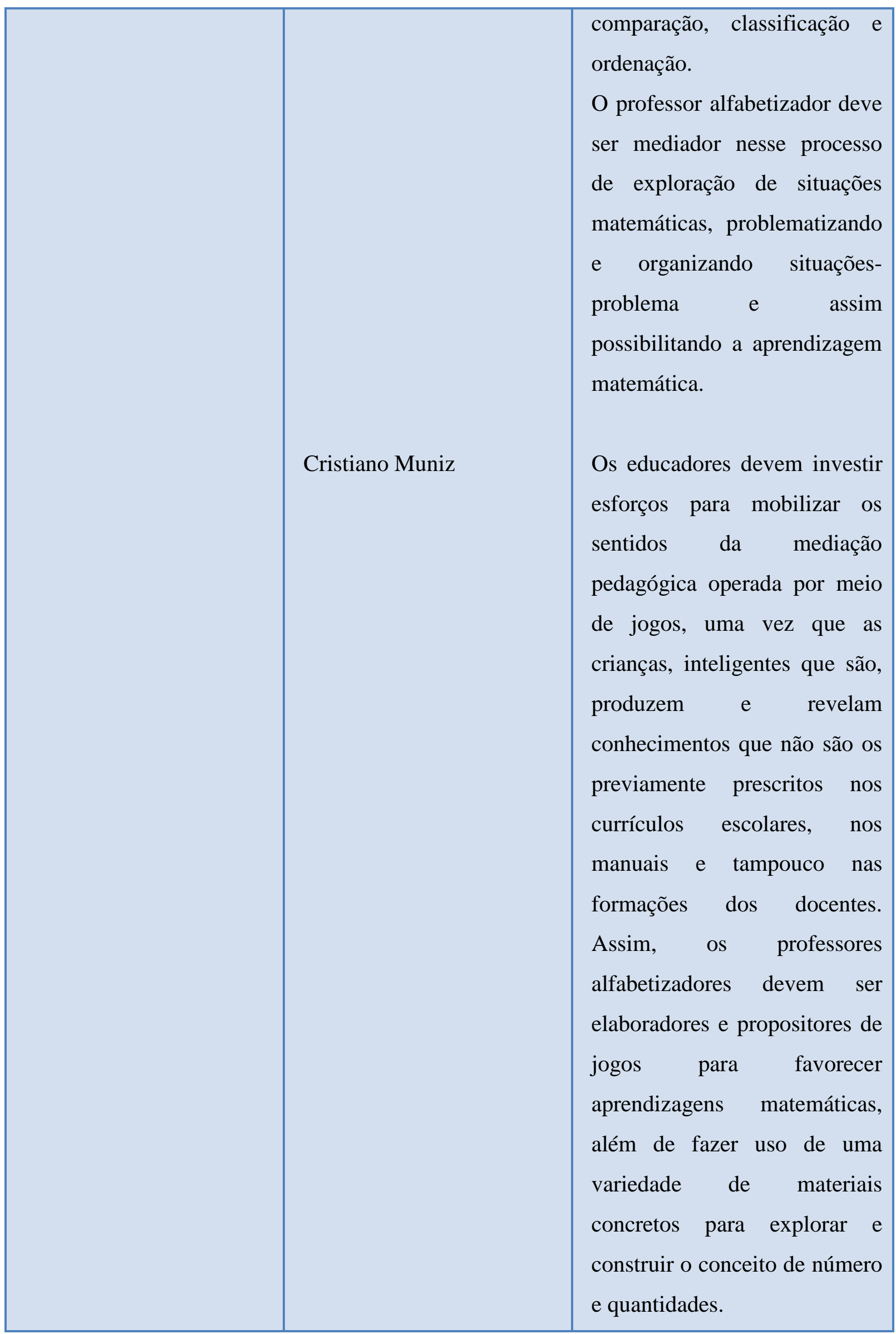




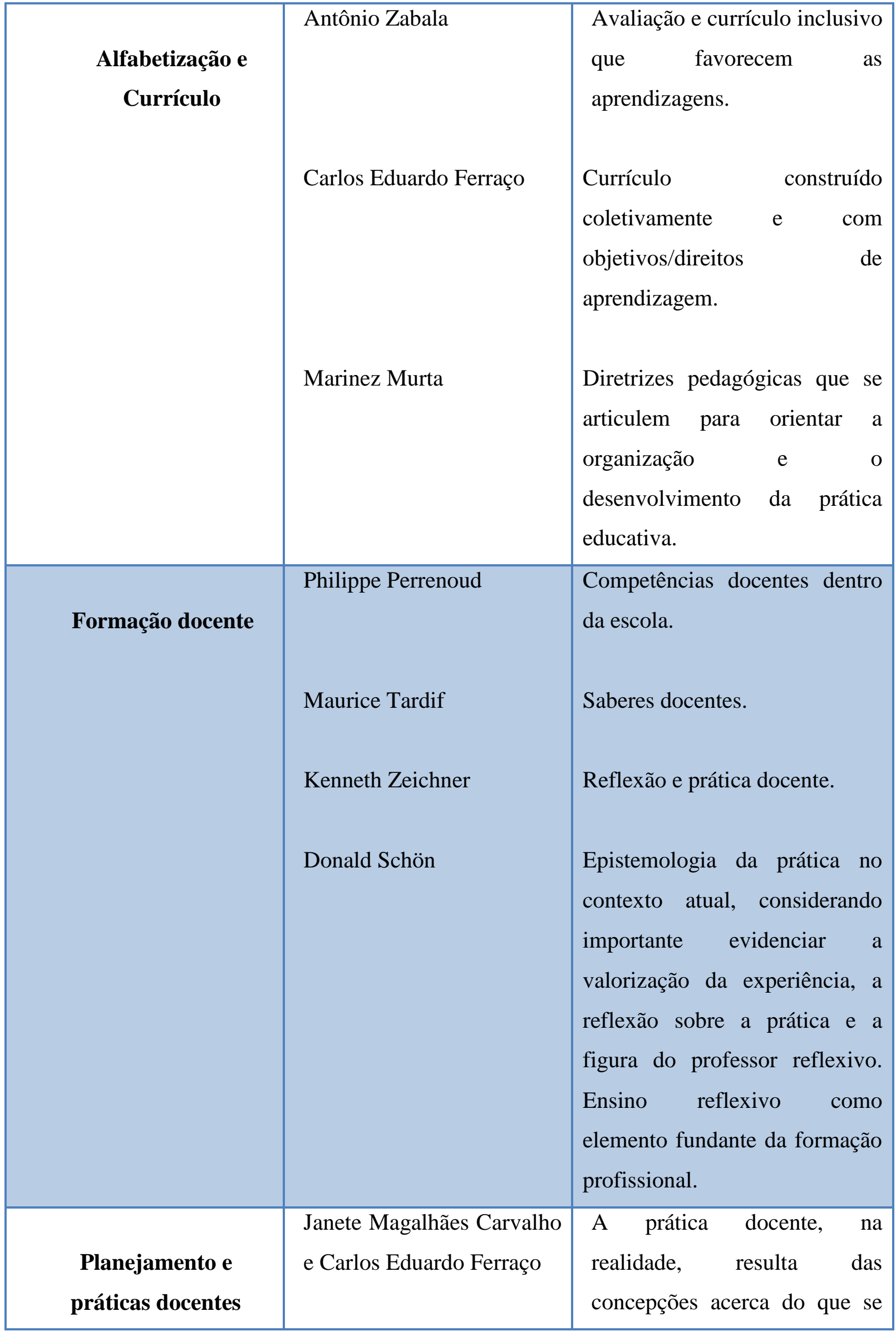




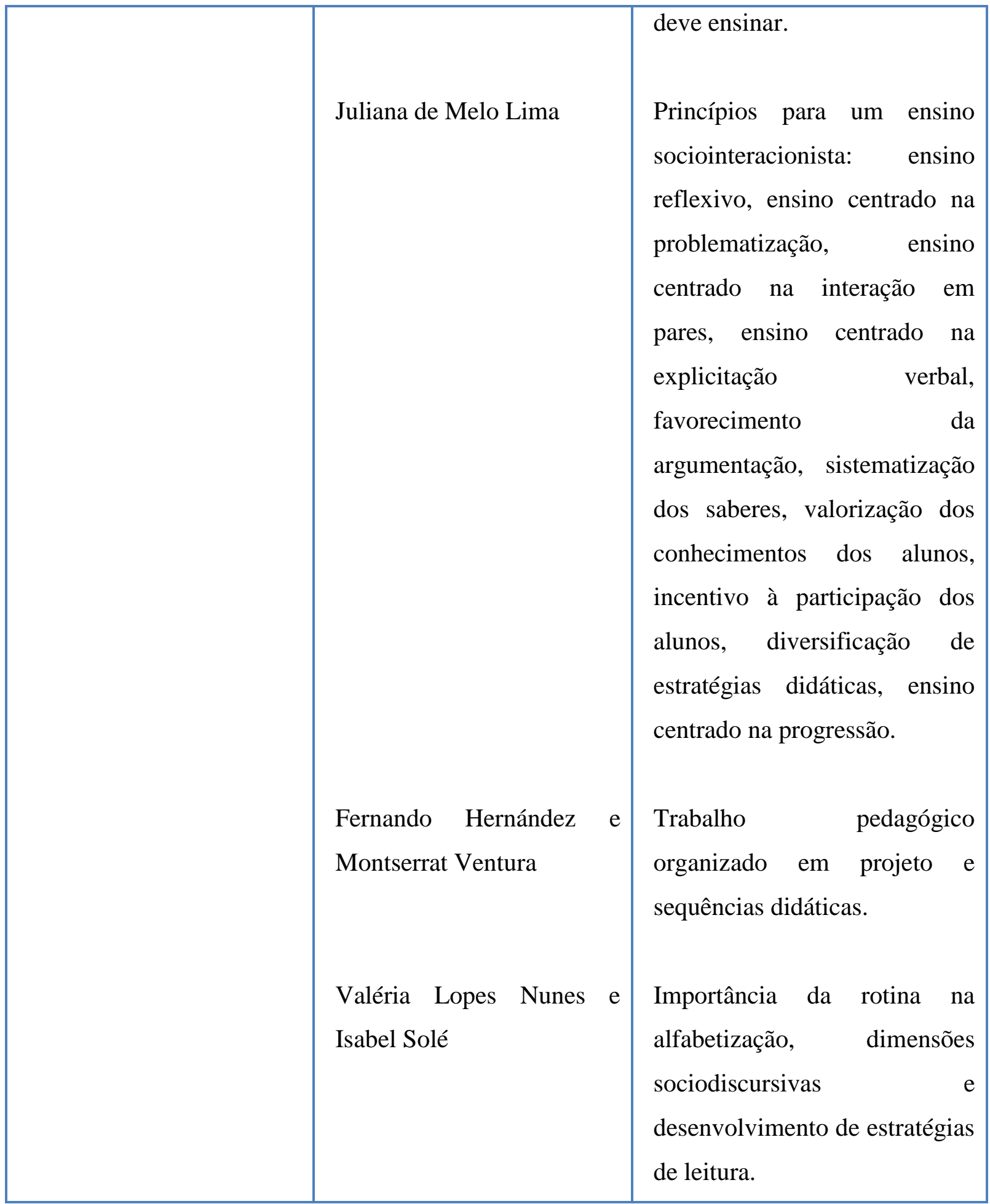

Fonte: Elaborado pela pesquisadora a partir da análise dos Documentos do PNAIC em outubro de 2016. 


\section{ANEXOS}

\section{PORTARIA Nº 867, DE 4 DE JULHO DE 2012 DOU 05/07/2012}

Institui o Pacto Nacional pela Alfabetização na Idade Certa e as ações do Pacto e define suas diretrizes gerais.

O MINISTRO DE ESTADO DA EDUCAÇÃO, no uso da atribuição que lhe confere o art. 87, inciso II, parágrafo único da Constituição Federal, e considerando o disposto nas Leis no 9.394, de 20 de dezembro de 1996, no 11.273 , de 06 de fevereiro de 2006 , e no art. $2^{\circ}$ do Decreto no 6.094 de 2007, no art. 2o do Decreto no 6.755 de 2009 e no art. 1o, parágrafo único do Decreto no 7.084 de 2010, resolve:

Art. $1^{\circ}$ Fica instituído o Pacto Nacional pela Alfabetização na Idade Certa, pelo qual o Ministério da Educação (MEC) e as secretarias estaduais, distrital e municipais de educação reafirmam e ampliam o compromisso previsto no Decreto no 6.094, de 24 de abril de 2007, de alfabetizar as crianças até, no máximo, os oito anos de idade, ao final do $3^{\circ}$ ano do ensino fundamental, aferindo os resultados por exame periódico específico, que passa a abranger: I - a alfabetização em língua portuguesa e em matemática; II - a realização de avaliações anuais universais, pelo Instituto Nacional de Estudos e Pesquisas Educacionais Anísio Teixeira - INEP, para os concluintes do $3^{\circ}$ ano do ensino fundamental;

III - o apoio gerencial dos estados, aos municípios que tenham aderido às ações do Pacto, para sua efetiva implementação.

Parágrafo único. A pactuação com cada ente federado será formalizada em instrumento próprio a ser disponibilizado pelo MEC.

Art. $2^{\circ}$ Ficam instituídas as ações do Pacto, por meio do qual o MEC, em parceria com instituições de ensino superior, apoiará os sistemas públicos de ensino dos Estados, Distrito Federal e Municípios na alfabetização e no letramento dos estudantes até o final do $3^{\circ}$ ano do ensino fundamental, em escolas rurais e urbanas, e que se caracterizam:

I - pela integração e estruturação, a partir do eixo Formação Continuada de Professores Alfabetizadores, de ações, materiais e referências curriculares e pedagógicas do MEC que 
$\begin{array}{llllll}\text { contribuam } & \text { para } & \text { a } & \text { alfabetização } & \text { e } & \text { o }\end{array}$ II - pelo compartilhamento da gestão do programa entre a União, Estados, Distrito Federal e Municípios;

III - pela garantia dos direitos de aprendizagem e desenvolvimento, a serem aferidos nas avaliações externas anuais. Parágrafo único. A pactuação referida no parágrafo único do art. $1^{\circ}$ é condição para a adesão de Estados, Distrito Federal e Municípios às ações do Pacto.

Art. $3^{\circ} \mathrm{A}$ adesão às referidas ações será formalizada em instrumento próprio a ser disponibilizado pelo MEC.

Art. $4^{\circ}$ Os entes governamentais que aderirem ao Pacto e optarem por não participar das ações mencionadas por já desenvolverem programas próprios de alfabetização em seus sistemas de ensino poderão contar com apoio técnico e financeiro do MEC, por meio do Plano de Ações Articuladas - PAR, para implementação dos mesmos.

Art. $5^{\circ}$ As ações do Pacto tem por objetivos:

I - garantir que todos os estudantes dos sistemas públicos de ensino estejam alfabetizados, em Língua Portuguesa e em Matemática, até o final do $3^{\circ}$ ano do ensino fundamental; II - reduzir a distorção idade-série na Educação Básica; III - melhorar o Índice de Desenvolvimento da Educação Básica (IDEB); IV - contribuir para o aperfeiçoamento da formação dos professores alfabetizadores; $\mathrm{V}$ - construir propostas para a definição dos direitos de aprendizagem e desenvolvimento das crianças nos três primeiros anos do ensino fundamental.

Art. $6^{\circ}$ As ações do Pacto compreendem os seguintes eixos:

\begin{tabular}{lcccccr} 
I & - & formação & \multicolumn{2}{c}{ continuada de } & professores & alfabetizadores; \\
II & - & materiais & didáticos, literatura & e & tecnologias & educacionais; \\
III & & & - & & avaliação & e;
\end{tabular}

IV - gestão, controle e mobilização social.

Art. $7^{\circ} \mathrm{O}$ eixo formação continuada de professores alfabetizadores caracteriza-se por:

I - formação dos professores alfabetizadores das escolas das redes de ensino participantes das ações do Pacto; II - formação e constituição de uma rede de professores orientadores de estudo. Parágrafo único. O MEC poderá conceder bolsas para os orientadores de estudo e professores alfabetizadores, nos termos da Lei $\mathrm{n}^{\circ} 11.273$, de 2006, com valores e critérios regulamentados em resolução específica do Fundo Nacional de Desenvolvimento da Educação - FNDE. 
Art. $8^{\circ} \mathrm{O}$ eixo materiais didáticos, literatura e tecnologias educacionais caracteriza-se pela disponibilização pelo MEC, para as escolas participantes, de: I - livros didáticos de $1^{\circ}, 2^{\circ}$ e $3^{\circ}$ anos do ensino fundamental, e respectivos manuais do professor, a serem distribuídos pelo Programa Nacional do Livro Didático - PNLD; II - obras pedagógicas complementares aos livros didáticos distribuídos pelo Programa Nacional do Livro Didático - $\quad$ Obras Complementares; III - jogos pedagógicos para apoio à alfabetização; IV - obras de referência, de literatura e de pesquisa distribuídas pelo Programa Nacional Biblioteca na Escola

PNBE; V - obras de apoio pedagógico aos professores, distribuídas por meio do PNBE; VI - tecnologias educacionais de apoio à alfabetização.

Art. $9^{\circ} \mathrm{O}$ eixo avaliação caracteriza-se por:

I - avaliação do nível de alfabetização, mediante a aplicação anual da Provinha Brasil aos estudantes das escolas participantes, pelas próprias redes de ensino, no início e no final do $2^{\circ}$ ano do ensino fundamental; II - disponibilização pelo INEP, para as redes públicas, de sistema informatizado para coleta e tratamento dos resultados da Provinha Brasil; III - análise amostral, pelo INEP, dos resultados registrados após a aplicação da Provinha Brasil, no final do $\quad 2^{\circ}$ ano; IV - avaliação externa universal do nível de alfabetização ao final do $3^{\circ}$ ano do ensino fundamental, aplicada pelo INEP.

Art. 10. O eixo gestão, controle e mobilização social caracteriza-se por:

I - constituição de um arranjo institucional para gestão das ações do Pacto, organizado na forma abaixo:

a) Comitê Gestor Nacional: responsável pela coordenação e avaliação em âmbito nacional, presidido pela Secretaria Executiva do Ministério da Educação, com participação dos titulares e suplentes da Secretaria de Educação Básica (SEB), da Secretaria de Educação Continuada, Alfabetização, Diversidade e Inclusão (SECADI), da Secretaria de Articulação com os Sistemas de Ensino (SASE), do FNDE, do INEP, do Conselho Nacional dos Secretários Estaduais de Educação (CONSED), da União dos Dirigentes Municipais de Educação (UNDIME) e representantes de outros órgãos e entidades que o Comitê julgar conveniente;

b) Coordenação Institucional: comitê composto, em cada estado, por representante do MEC, da Secretaria de Estado da Educação, da UNDIME no estado, da União dos Conselhos Municipais de Educação (UNCME) no estado, do Conselho Estadual de Educação, da(s) 
Instituições de Ensino Superior (IES) formadora(s) em atuação no estado e de outras entidades que a Coordenação julgar conveniente, responsável pela mobilização e a proposição e soluções para temas estratégicos, no âmbito do estado;

c) Coordenação Estadual: a cargo de cada Secretaria de Estado da Educação, responsável pela gestão, supervisão, monitoramento no âmbito da rede estadual e pelo apoio à implementação das ações do Pacto nos municípios;

d) Coordenação Municipal: a cargo da Secretaria Municipal de Educação, responsável pela gestão, supervisão, monitoramento das ações do Pacto no âmbito da rede municipal e pela interlocução com a coordenação estadual.

II - definição e disponibilização, pelo MEC, de um sistema de monitoramento das referidas ações do Pacto;

III - promoção, por meio do Conselho Municipal, dos conselhos escolares, dos conselhos de acompanhamento e controle social da educação e organizações da sociedade civil, do acompanhamento e monitoramento das ações do Pacto, bem como de todas as demais ações de caráter suplementar com impacto direto na aprendizagem e permanência da criança na escola;

IV - fortalecimento dos conselhos de educação e escolares envolvidos no acompanhamento e monitoramento das ações do Pacto, visando garantir as condições necessárias para o seu pleno e eficaz desenvolvimento;

V - mobilização da comunidade escolar, dos conselhos de educação e da sociedade local em torno das ações do Pacto.

Art. 11. Caberá ao MEC:

I - aplicar as avaliações externas do nível de alfabetização em Língua Portuguesa e em Matemática, para alunos concluintes do $3^{\circ}$ ano do ensino fundamental;

II - distribuir a Provinha Brasil para aplicação pelas próprias redes junto aos alunos ingressantes e concluintes do $2^{\circ}$ ano do ensino fundamental;

III - desenvolver e disponibilizar, para as redes de ensino, sistema informatizado para coleta e tratamento dos resultados da Provinha Brasil;

IV - promover, em parceria com as Instituições de Ensino Superior (IES), a formação dos orientadores de estudo e dos professores alfabetizadores nas redes de ensino que aderirem às ações do Pacto;

V - conceder bolsas de apoio para incentivar a participação dos orientadores de estudo e dos professores alfabetizadores nas atividades de formação nas redes de ensino que aderirem às ações do Pacto; 
VI - fornecer os materiais didáticos, literários, jogos e tecnologias previstos nos artigos $6^{\circ}, 7^{\circ}$ e $8^{\circ}$ desta Portaria, nas redes de ensino que aderirem às ações do Pacto;

VII - fomentar as ações de mobilização e de gestão.

Art. 12. Caberá às IES:

I - realizar a gestão acadêmica e pedagógica do curso de formação; II - selecionar os formadores que ministrarão o curso de formação aos orientadores de estudo; III - assegurar espaço físico e material de apoio adequados para os encontros presenciais da formação dos professores orientadores de estudo; IV - certificar os professores orientadores de estudos e os professores alfabetizadores que tenham concluído o curso de formação; V - apresentar relatórios parciais e finais sobre a execução do curso de formação, no modelo e dentro dos prazos estipulados nos planos de trabalho pelo MEC.

Art. 13. Caberá aos Estados e ao Distrito Federal:

I - aderir ao Pacto Nacional pela Alfabetização na Idade Certa; II - promover a participação das escolas de sua rede de ensino nas avaliações realizadas pelo INEP;

III - aplicar a Provinha Brasil em sua rede, no início e no final do $2^{\circ}$ ano do ensino fundamental, e informar os resultados por meio de sistema informatizado específico; IV - instituir e viabilizar o funcionamento da coordenação institucional no âmbito do Estado ou Distrito

Federal;

V - gerenciar e monitorar a implementação das ações do Pacto em sua rede; VI - designar coordenador(es) para se dedicar(em) às ações do Pacto e alocar equipe necessária para a sua gestão, inclusive em suas unidades regionais; VII - indicar orientadores de estudo de sua rede de ensino e custear o seu deslocamento e a sua hospedagem para os eventos de formação; VIII - fomentar e garantir a participação dos professores alfabetizadores de sua rede de ensino nas atividades de formação, sem prejuízo da carga-horária em sala de aula, custeando o deslocamento e a hospedagem, sempre que necessário; IX - monitorar, em colaboração com os municípios e com o MEC, a aplicação da Provinha Brasil e da avaliação externa, a entrega e o uso dos materiais de apoio à alfabetização, previstos nesta

Portaria; $\mathrm{X}$ - disponibilizar Assistência Técnica às escolas e aos municípios com maiores dificuldades na implementação das ações do Pacto e na obtenção de resultados positivos de alfabetização; XI - promover a articulação das ações do Pacto com o Programa Mais Educação, onde 
houver, priorizando o atendimento das crianças do $1^{\circ}, 2^{\circ}$ e $3^{\circ}$ ano do ensino fundamental como garantia de educação integral e complementação e apoio pedagógico àquelas com maiores dificuldades.

Art. 14. Caberá aos Municípios:

I - aderir ao Pacto Nacional pela Alfabetização na Idade Certa; II - promover a participação das escolas da rede nas avaliações realizadas pelo INEP; III - aplicar a Provinha Brasil em sua rede de ensino, no início e no final do $2^{\circ}$ ano do ensino fundamental, e informar os resultados por meio de sistema informatizado específico; IV - gerenciar e monitorar a implementação das ações do Pacto em sua rede; V - designar coordenador(es) para se dedicar(em) às ações do Pacto e alocar equipe necessária para a sua gestão, inclusive em suas unidades regionais, se houver; VI - indicar os orientadores de estudo de sua rede de ensino e custear o seu deslocamento e a sua hospedagem para os eventos de formação; VII - fomentar e garantir a participação dos professores alfabetizadores de sua rede de ensino nas atividades de formação, sem prejuízo da carga-horária em sala de aula, custeando o deslocamento e a hospedagem, sempre que necessário; VIII - monitorar, em colaboração com o MEC, a aplicação da Provinha Brasil e da avaliação externa, a entrega e o uso dos materiais de apoio à alfabetização previstos nesta Portaria; IX - disponibilizar assistência técnica às escolas com maiores dificuldades na implementação das ações do Pacto e na obtenção de resultados positivos de alfabetização; $\mathrm{X}$ - promover a articulação das ações do Pacto com o Programa Mais Educação, onde houver, priorizando o atendimento das crianças do $1^{\circ}, 2^{\circ}$ e $3^{\circ}$ ano do ensino fundamental como garantia de educação integral e complementação e apoio pedagógico àquelas com maiores dificuldades.

Art. 15. O MEC implementará medidas destinadas ao reconhecimento dos esforços realizados pelas escolas e de estímulo ao alcance do objetivo central de alfabetizar todas as crianças até o final do ciclo de alfabetização.

Art. 16. Esta Portaria entra em vigor na data da sua publicação. ALOIZIO MERCADANTE OLIVA 


\section{MEDIDA PROVISÓRIA Nº 586, DE 8 DE NOVEMBRO DE 2012.}

Dispõe sobre o apoio técnico e financeiro da União aos entes federados no âmbito do Pacto Nacional pela Alfabetização na Idade Certa, e dá outras providências.

A PRESIDENTA DA REPÚBLICA, no uso da atribuição que lhe confere o art. 62 da Constituição, adota a seguinte Medida Provisória, com força de lei:

Art. 1o Esta Medida Provisória dispõe sobre o apoio técnico e financeiro da União aos entes federados no âmbito do Pacto Nacional pela Alfabetização na Idade Certa, com a finalidade de promover a alfabetização dos estudantes até os oito anos de idade, ao final do 30 ano do ensino fundamental da educação básica pública, aferida por avaliações periódicas.

Art. 20 O apoio financeiro da União aos entes federados no âmbito do Pacto Nacional pela Alfabetização na Idade Certa será realizado pelo Fundo Nacional de Desenvolvimento da Educação - FNDE, e ocorrerá por meio de:

I - suporte à formação continuada dos professores alfabetizadores; e

II - reconhecimento dos resultados alcançados pelas escolas e pelos profissionais da educação no desenvolvimento das ações do Pacto Nacional pela Alfabetização na Idade Certa.

$\S 1$ o O apoio financeiro de que trata o inciso I do caput contemplará a concessão de bolsas para profissionais da educação, conforme categorias e parâmetros definidos em ato do Ministro de Estado da Educação, e o desenvolvimento de recursos didáticos e pedagógicos, entre outras medidas.

$\S 20$ O apoio financeiro de que trata o inciso II do caput será efetivado na forma estabelecida nos arts. 22 a 29 da Lei no 11.947, de 16 de junho de 2009.

Art. 3o Ato do Ministro de Estado da Educação disporá sobre:

I - assistência técnica a ser ofertada pela União no âmbito do Pacto Nacional pela Alfabetização na Idade Certa;

II - atividades a serem implementadas para alcançar os objetivos do Pacto Nacional pela Alfabetização na Idade Certa; e

III - metas que integrarão o Pacto Nacional pela Alfabetização na Idade Certa.

Art. 4o A Lei no 5.537, de 21 de novembro de 1968, passa a vigorar com as seguintes alterações:

e) prestar assistência técnica e financeira, conforme disponibilidade de dotações orçamentárias, para aperfeiçoar o processo de aprendizagem na educação básica pública, por meio da melhoria da estrutura física ou pedagógica das escolas;

f) operacionalizar programas de financiamento estudantil. 
§ 5o A assistência técnica de que trata a alínea "e" ocorrerá pela disponibilização de bens, materiais pedagógicos e capacitação aos sistemas de ensino e de gestão dos programas educacionais, ou pela disponibilização de instrumentos administrativos que promovam a eficiência na execução das ações e projetos educacionais.

$\S 60$ A assistência financeira de que trata a alínea "e" ocorrerá por meio de:

I - transferência de recursos para execução das ações pelos entes federados, por suas redes de ensino ou por unidades executoras e demais entidades que desenvolvam atividades educacionais, conforme legislação orçamentária; e

II - concessão de bolsas, ressarcimento de despesas e outros mecanismos de incentivo e reconhecimento ao desenvolvimento da educação básica pública, à formação e à capacitação os agentes públicos vinculados à educação ou à execução dos programas educacionais.

$\S 7$ o A prestação de assistência técnica e financeira referida nos $\S 5$ o e 60 será regulamentada pelo Conselho Deliberativo do FNDE." (NR)

“Art. 7o A implementação das ações educacionais a cargo do FNDE será regulamentada por seu Conselho Deliberativo, órgão de deliberação superior, cuja composição e forma de funcionamento constarão de sua estrutura regimental.” (NR)

Art. 5o A Lei no 8.405, de 9 de janeiro de 1992, passa a vigorar com as seguintes alterações:

$\S$ 6o No âmbito de programas de cooperação internacional, a CAPES poderá conceder no Brasil e no exterior, bolsas a estudantes, pesquisadores e professores estrangeiros, vinculados a projetos desenvolvidos por instituições públicas de ensino superior brasileiras e estrangeiras associadas, visando a formação inicial e continuada de profissionais do magistério para educação básica e superior e a internacionalização da produção científica e tecnológica do Brasil.” (NR)

Art. 6o Esta Medida Provisória entra em vigor na data de sua publicação.

Brasília, 8 de novembro de 2012; 191 o da Independência e 124o da República.

DILMA ROUSSEFF

GUIDO MANTEGA

ALOIZIO MERCADANTE MIRIAM BELCHIOR 


\section{PORTARIA N 1.458, DE 14 DE DEZEMBRO DE 2012 DOU de 18/12/2012 (n 243, Seção 1, pág. 15)}

Define categorias e parâmetros para a concessão de bolsas de estudo e pesquisa no âmbito do Pacto Nacional pela Alfabetização na Idade Certa, na forma do art. $2^{\circ}$, inciso I, da Portaria MEC nº 867, de 4 de julho de 2012.

O MINISTRO DE ESTADO DA EDUCAÇÃO, INTERINO, no uso das atribuições que lhe conferem o art. 87, parágrafo único, inciso II da Constituição, e art. $2^{\circ}, \S 1^{\circ}$ da Medida Provisória $\mathrm{n}^{\mathrm{o}}$ 586, de 8 de novembro de 2012, resolve:

Art. $1^{\circ}$ - A Formação Continuada de Professores Alfabetizadores tem como objetivo apoiar todos os professores que atuam no ciclo de alfabetização, incluindo os que atuam nas turmas multisseriadas e multietapa, a planejarem as aulas e a usarem de modo articulado os materiais e as referências curriculares e pedagógicas ofertados pelo MEC às redes que aderirem ao Pacto Nacional pela Alfabetização na Idade Certa e desenvolverem as ações desse Pacto.

Art. $2^{\circ}$ - A Formação Continuada de Professores Alfabetizadores utilizará material próprio a ser fornecido pelo MEC a todos os orientadores de estudo e professores alfabetizadores cursistas e será ofertada de forma presencial, com duração de:

I - duzentas horas anuais, incluindo atividades extra-classe, para os orientadores de estudo; e

II - cento e vinte horas anuais, incluindo atividades extra-classe, para os professores alfabetizadores.

Art. $3^{\circ}$ - A Formação Continuada de Professores Alfabetizadores, ofertada por instituições de ensino superior (IES) formadoras definidas pelo MEC, será ministrada aos orientadores de estudo que, por sua vez, serão os responsáveis pela formação dos professores alfabetizadores.

$\S 1^{\circ}$ - Os recursos para realização da Formação Continuada de Professores Alfabetizadores serão alocados diretamente no orçamento das instituições de ensino superior (IES) ou transferidos por meio de descentralizações, convênios ou outras formas de transferência.

$\S 2^{\circ}$ - As IES utilizarão os recursos referidos no parágrafo anterior exclusivamente para a implementação das atividades necessárias à Formação Continuada de Professores 
Alfabetizadores, podendo aplicá-los, dentre outras, nas seguintes finalidades: aquisição de equipamentos; material de consumo; contratação de serviços; pagamento de diárias e passagens; e apoio técnico.

$\S 3^{\circ}$ - A equipe docente das IES formadoras, os coordenadores das ações do Pacto nos estados, Distrito Federal e municípios, os orientadores de estudo e os professores alfabetizadores, enquanto atuarem na Formação Continuada de Professores Alfabetizadores poderão receber bolsas, na forma e valores definidos em resolução específica do Fundo Nacional de Desenvolvimento da Educação - FNDE.

Art. $4^{\circ}$ - A Formação Continuada de Professores Alfabetizadores contempla o pagamento de bolsas para as seguintes funções:

I - coordenador-geral da IES;

II - coordenador-adjunto junto à IES;

III - supervisor junto à IES;

IV - formador junto à IES;

V - coordenador das ações do Pacto nos estados, Distrito Federal e municípios;

VI - orientador de estudo; e

VII - professor alfabetizador.

Art. $5^{\circ}$ - O coordenador-geral da Formação Continuada de Professores Alfabetizadores deverá ser indicado pelo dirigente máximo da IES, que o escolherá, prioritariamente, dentre aqueles que atendam aos seguintes requisitos cumulativos:

I - ser professor efetivo da IES;

II - ter experiência na área de formação continuada de profissionais da educação básica; e

III - possuir titulação de mestrado ou doutorado. 
Parágrafo único - O coordenador-geral deverá encaminhar ao gestor nacional da Formação Continuada de Professores Alfabetizadores na Secretaria de Educação Básica/MEC, por intermédio dos sistemas disponibilizados pelo MEC, cópia de seu Termo de Compromisso de Bolsista, devidamente assinada e homologada pelo dirigente máximo da IES, e do instrumento comprobatório da sua designação.

Art. $6^{\circ}$ - O coordenador-adjunto será indicado pelo coordenador-geral da Formação na IES, devendo ser selecionado dentre os que reúnam, no mínimo, os seguintes requisitos cumulativos:

I - ser professor efetivo de instituição de ensino superior;

II - ter experiência na área de formação de professores alfabetizadores; e

III - possuir titulação de especialização, mestrado ou doutorado.

$\S 1^{\circ}$ - A indicação do coordenador-adjunto deverá ser homologada pelo dirigente máximo da IES, em seu Termo de Compromisso.

$\S 2^{\circ}$ - As IES responsáveis pela realização da Formação Continuada de Professores Alfabetizadores em mais de uma unidade da federação poderão indicar até um coordenadoradjunto para cada estado de atuação.

Art. $7^{\circ}$ - Os supervisores serão escolhidos em processo de seleção público e transparente, respeitando-se os pré-requisitos estabelecidos para a função quanto à formação e à experiência exigidas, dentre candidatos que reúnam, no mínimo, as seguintes características cumulativas:

I - ter experiência na área de formação de professores alfabetizadores; e

II - possuir titulação de especialização, mestrado ou doutorado.

Parágrafo único - Caso já seja bolsista de outro programa de formação de professores para a educação básica, o supervisor selecionado, ainda que não possa acumular o recebimento de bolsa em mais do que um deles, poderá assumir esta função, desde que não haja qualquer comprometimento ao desempenho de suas responsabilidades e atribuições regulares, seja em termos de sua jornada de trabalho seja em termos de dedicação e comprometimento.

Art. $8^{\circ}$ - Os formadores serão selecionados pelo coordenador-geral da IES, em processo de seleção público e transparente, respeitando-se os pré-requisitos estabelecidos para a função quanto à formação e à experiência exigidas, dentre candidatos que reúnam, no mínimo, as seguintes características cumulativas:

I - ter experiência na área de formação de professores alfabetizadores; 
II - ter atuado como professor alfabetizador ou formador de professores alfabetizadores durante, pelo menos, dois anos;

III - ser formado em pedagogia ou áreas afins ou ter licenciatura; e

IV - possuir titulação de especialização, mestrado ou doutorado ou estar cursando pósgraduação na área de educação.

Art. $9^{\circ}$ - O coordenador das ações do Pacto no Distrito Federal, nos estados ou nos municípios será indicado pela respectiva secretaria de educação e deverá ser selecionado, preferencialmente, dentre aqueles que atendam às seguintes características cumulativas:

I - ser servidor efetivo da secretaria de educação;

II - ter experiência na coordenação de projetos ou programas federais;

III - possuir amplo conhecimento da rede de escolas, dos gestores escolares e dos docentes envolvidos no ciclo de alfabetização;

IV - ter capacidade de se comunicar com os atores locais envolvidos no ciclo de alfabetização e de mobilizá-los; e

$\mathrm{V}$ - ter familiaridade com os meios de comunicação virtuais.

$\S 1^{\circ}$ - É vedada a designação de qualquer dirigente da educação do estado, do Distrito Federal ou do município para atuar como coordenador das ações do Pacto.

$\S 2^{\circ}$ - Na hipótese de a secretaria não conseguir selecionar um profissional com o perfil requerido ou com disponibilidade para assumir a coordenação das ações do Pacto entre os servidores de seu quadro efetivo, poderá, excepcionalmente, indicar profissional contratado ou com vínculo de trabalho temporário.

$\S 3^{\circ}$ - Caso o coordenador das ações do Pacto no Distrito Federal, nos estados ou nos municípios já seja bolsista de outro programa de formação de professores para a educação básica, não poderá acumular o recebimento de bolsa em mais do que um dos programas, mas poderá assumir a função, desde que não haja qualquer comprometimento ao desempenho de suas responsabilidades e atribuições regulares, seja em termos da jornada de trabalho seja em termos de dedicação e comprometimento.

$\S 4^{\circ}$ - O atendimento aos requisitos estabelecidos no caput e nos $\S \S 1^{\circ}, 2^{\circ}$ e $3^{\circ}$ deste artigo é de responsabilidade de cada ente federativo, podendo o MEC, o FNDE ou os órgãos de controle do Governo Federal, a qualquer tempo, solicitar esclarecimentos ou documentos comprobatórios do cumprimento de tais requisitos.

Art. 10 - Os orientadores de estudo serão escolhidos em processo de seleção público e transparente, respeitando-se os pré-requisitos estabelecidos para a função quanto à formação e 
à experiência exigidas, dentre candidatos que reúnam, no mínimo, as seguintes características cumulativas:

I - ser professor efetivo da rede pública de ensino que promove a seleção;

II - ter sido tutor do Programa Pró-Letramento; e

III - ter disponibilidade para dedicar-se ao curso e à multiplicação junto aos professores alfabetizadores.

$\S 1^{\circ}$ - Caso na rede de ensino não estejam disponíveis professores que tenham sido tutores do Pró-Letramento ou por outras razões que deverão ser devidamente justificadas no momento do cadastramento, na seleção dos orientadores de estudo a secretaria de educação deverá considerar o currículo, a experiência e a habilidade didática do candidato, sendo que o selecionado deve preencher os seguintes requisitos cumulativos:

I - ser profissional do magistério efetivo da rede;

II - ser formado em pedagogia ou ter licenciatura; e

III - atuar há, no mínimo, três anos nos anos iniciais do ensino fundamental, como professor ou coordenador pedagógico ou possuir experiência comprovada na formação de professores alfabetizadores.

$\S 2^{\circ}$ - Os coordenadores pedagógicos só poderão participar da Formação, na condição de professores, alfabetizadores e receber a respectiva bolsa de estudo se atenderem aos seguintes requisitos cumulativos:

I - lecionar em turmas do $1^{\circ}, 2^{\circ}, 3^{\circ}$ ano ou em turmas multisseriadas formadas por alunos desses anos; e

II - constar do Censo Escolar disponível no momento da constituição da turma de professores alfabetizadores da Formação do qual participará.

$\S 3^{\circ}$ - Os requisitos previstos no caput e nos $\S \S 1^{\circ}$ e $2^{\circ}$ deverão ser documentalmente comprovados pelo(a) orientador(a) de estudo no ato da matrícula na IES responsável pela Formação.

Art. 11 - O orientador de estudo deverá permanecer como professor do quadro efetivo do magistério da rede pública de ensino que o indicou durante toda a realização da Formação Continuada de Professores Alfabetizadores, sob pena de exclusão do curso e devolução do valor relativo às bolsas recebidas.

$\S 1^{\circ}$ - O orientador de estudo somente poderá ser substituído nos seguintes casos:

I - deixar de cumprir os requisitos previstos no art. 10 desta Portaria; ou

II - por solicitação do próprio orientador de estudo. 
$\S 2^{\circ}$ - Em caso de substituição de orientador de estudo, o coordenador das ações do Pacto no estado ou município deverá encaminhar documento que a justifique à IES formadora.

$\S 3^{\circ}$ - Em caso de substituição do orientador de estudo, a IES formadora realizará a formação necessária para o seu substituto, visando compensar a ausência nos encontros formativos anteriores.

Art. 12 - Revoga-se o parágrafo único do art. $7^{\circ}$ da Portaria MEC no 867 , de 4 de julho de 2012.

Art. 13 - Esta Portaria entra em vigor na data de sua publicação.

JOSÉ HENRIQUE PAIM FERNANDES 


\section{RESOLUÇÃO Nº 4 DE 27 DE FEVEREIRO DE 2013}

Estabelece orientações e diretrizes para o pagamento de bolsas de estudo e pesquisa para a Formação Continuada de Professores Alfabetizadores, no âmbito do Pacto Nacional pela Alfabetização na Idade Certa.

\section{FUNDAMENTAÇÃO LEGAL}

Constituição Federal de 1988, artigos 205, 206, 211 e 214; Lei no 9.394, de 20 de dezembro de 1996; Lei $\mathrm{n}^{\mathrm{o}}$ 11.273, de 6 de fevereiro de 2006; Medida Provisória $\mathrm{n}^{\circ}$ 586, de 08 de novembro de 2012; Decreto $n^{\circ} 6.094$ de 24 de abril de 2007; Decreto $n^{\circ} 6.755$, de 29 de janeiro de 2009; Portaria MEC nº 1.243, de 30 de dezembro de 2009; Portaria MEC no 867, de 4 de julho de 2012; Portaria MEC no 1.458, de 14 de dezembro de 2012; e Portaria MEC no 90, de 6 de fevereiro de 2013.

\section{O PRESIDENTE DO CONSELHO DELIBERATIVO DO FUNDO NACIONAL DE} DESENVOLVIMENTO DA EDUCAÇÃO (FNDE), no uso das atribuições que lhe são conferidas pelo art. $7^{\circ}, \S 1^{\circ}$, da Lei $n^{\circ} 5.537$, de 21 de novembro de 1968 , e pelos arts. $4^{\circ}, \S 2^{\circ}$, e 14 do Anexo I do Decreto no 7.691, de 2 de março de 2012, publicado no D.O.U. de 6 de março de 2012, e pelos arts. $3^{\circ}$, inciso I, alíneas "a" e "b"; 5 , caput; e 6º inciso VI, do Anexo da Resolução no 31, de 30 de setembro de 2003, publicada no D.O.U. de 2 de outubro de 2003, neste ato representado conforme deliberado na Reunião Extraordinária do Conselho Deliberativo do FNDE realizada no dia 31 de maio de 2012, e CONSIDERANDO o desafio de alcançar, em 2022, um nível de desenvolvimento da educação básica equivalente à média dos países integrantes da Organização para a Cooperação e o Desenvolvimento Econômico (OCDE); CONSIDERANDO o compromisso assumido por todos os entes governamentais, no âmbito do Decreto 6.094/2007, de alfabetizar todas as crianças até, no máximo, os oito anos de idade; CONSIDERANDO a Política Nacional de Formação de Profissionais do Magistério, instituída pelo Decreto $n^{\circ}$ 6.755, de 29 de janeiro de 2009, que estabelece orientações para a formação de professores no âmbito do Plano de Desenvolvimento da Educação (PDE), RESOLVE “AD REFERENDUM”:

Art. $1^{\circ}$ Estabelecer os critérios e normas para o pagamento de bolsas de estudo e pesquisa aos participantes da Formação Continuada de Professores Alfabetizadores no âmbito do Pacto Nacional pela Alfabetização na Idade Certa, implementado pela Secretaria de Educação Básica do Ministério da Educação (SEB/MEC). 
Art. $2^{\circ}$ A Formação Continuada de Professores Alfabetizadores tem como objetivo apoiar todos os professores que atuam no ciclo de alfabetização, incluindo os que atuam nas turmas multisseriadas e multietapa, a planejarem as aulas e a usarem de modo articulado os materiais e as referências curriculares e pedagógicas ofertados pelo MEC às redes que aderirem ao Pacto Nacional pela Alfabetização na Idade Certa e desenvolverem as ações desse Pacto.

Art. $3^{\circ}$ A Formação Continuada de Professores Alfabetizadores utilizará material próprio a ser fornecido pelo MEC a todos os orientadores de estudo e professores alfabetizadores cursistas e será ofertada de forma presencial, com duração de: I - 200 (duzentas) horas anuais, incluindo atividades extra-classe, para os orientadores de estudo; II - 120 (cento e vinte) horas anuais, incluindo atividades extraclasse, para os professores alfabetizadores.

Art. $4^{\circ}$ A Formação Continuada de Professores Alfabetizadores, ofertada por instituições de ensino superior (IES) formadoras definidas pelo MEC, será ministrada aos orientadores de estudo que, por sua vez, serão os responsáveis pela formação dos professores alfabetizadores. $\S 1^{\circ}$ Os recursos para realização da Formação Continuada de Professores Alfabetizadores serão alocados diretamente no orçamento das Instituições de Ensino Superior (IES) ou transferidos por meio de descentralizações ou convênios com estas, tendo sua forma de execução regulamentada por resolução específica. $\S 2^{\circ}$ As IES utilizarão os recursos referidos no parágrafo anterior exclusivamente para a implementação das atividades necessárias à Formação Continuada de Professores Alfabetizadores, podendo aplicá-los, dentre outras, nas seguintes finalidades: aquisição de equipamentos; material de consumo; contratação de serviços; pagamento de diárias e passagens; e apoio técnico. $\S 3^{\circ}$ A equipe docente das IES formadoras, os coordenadores das ações do Pacto nos estados, Distrito Federal e municípios, os orientadores de estudo e os professores alfabetizadores, enquanto atuarem na Formação Continuada de Professores Alfabetizadores, receberão bolsa na forma, nos valores e conforme critérios definidos nesta resolução.

Art. $5^{\circ}$ A Formação Continuada de Professores Alfabetizadores contempla o pagamento de bolsas para as seguintes funções: I - coordenador-geral da IES; II - coordenador-adjunto junto à IES; III - supervisor junto à IES; IV - formador junto à IES; V - coordenador das ações do Pacto nos estados, Distrito Federal e municípios; VI - orientador de estudo; e 3 VII - professor alfabetizador. I - DOS AGENTES DA FORMAÇÃO, SUAS RESPONSABILIDADES E ATRIBUIÇÕES

Art. $6^{\circ}$ São agentes da Formação Continuada de Professores Alfabetizadores: I - Secretaria de Educação Básica do Ministério da Educação (SEB/MEC); II - Fundo Nacional de 
Desenvolvimento da Educação (FNDE); III - instituições de ensino superior (IES); IV secretarias de Educação dos estados, do Distrito Federal e dos municípios.

Art. $7^{\circ}$ São atribuições e responsabilidades dos agentes da Formação Continuada de Professores Alfabetizadores: I - da Secretaria de Educação Básica do Ministério da Educação - SEB/MEC: a) definir junto às instituições de ensino superior (IES), o conteúdo da Formação; b) articular os agentes envolvidos e promover, em parceria com as IES, a formação dos orientadores de estudo e dos professores alfabetizadores nas redes de ensino que aderirem às ações do Pacto; c) instituir, por portaria do dirigente da SEB/MEC, o gestor nacional da Formação Continuada de Professores Alfabetizadores, que será responsável pela interlocução com o FNDE nas questões relativas ao pagamento de bolsas no âmbito do Pacto Nacional pela Alfabetização na Idade Certa; d) garantir os recursos financeiros para a realização dos cursos pelas IES; e) definir os critérios de seleção dos bolsistas que atuarão como supervisores e formadores no âmbito das IES; f) conceder bolsas de estudo e pesquisa aos formadores, supervisores e coordenadores da Formação Continuada de Professores Alfabetizadores junto às IES; g) conceder bolsas de estudo aos coordenadores das ações do Pacto no Distrito Federal, nos estados e municípios, aos orientadores de estudo e aos professores das redes públicas participantes Formação Continuada de Professores Alfabetizadores no âmbito do Pacto Nacional pela Alfabetização na Idade Certa; h) garantir os recursos financeiros para o pagamento das bolsas tanto aos formadores, supervisores e coordenadores quanto aos professores das redes públicas participantes da Formação; i) fornecer às redes de ensino que aderirem às ações do Pacto os materiais didáticos, literários, jogos e tecnologias previstos nos artigos $6^{\circ}, 7^{\circ}$ e $8^{\circ}$ da Portaria MEC $n^{\circ} 867 / 2012$; j) fomentar as ações de mobilização e gestão da comunidade escolar; k) desenvolver e transferir metodologia para monitoramento e avaliação da Formação; 1) apoiar a gestão e o monitoramento local das ações do Pacto; m) manter em operação o SisPacto, sistema informatizado de gestão e de monitoramento do Pacto Nacional pela Alfabetização na Idade Certa; n) fornecer ao FNDE as metas anuais do Pacto e sua respectiva previsão de desembolso, bem como a estimativa da distribuição mensal de tais metas e dos recursos financeiros destinados ao pagamento de bolsas; o) gerar no sistema específico de pagamento de bolsas, o Sistema de Gestão de Bolsas - SGB, de acordo com calendário previamente estabelecido e depois de ter recebido da IES o respectivo relatório 4 mensal de ocorrências, os lotes mensais de bolsistas da Formação Continuada de Professores Alfabetizadores aptos a receberem bolsa no período de referência; p) autorizar e homologar a solicitação de pagamento de bolsa para os coordenadores-gerais das IES; q) monitorar o fluxo de concessão 
de bolsas da Formação, por meio tanto do SisPacto quanto do SGB, e de outros instrumentos que considerar apropriados para o acompanhamento, o monitoramento e a avaliação da consecução das metas físicas; r) comunicar oficialmente ao FNDE qualquer alteração cadastral de bolsista efetivada, bem como substituições e desistências dos bolsistas da Formação Continuada de Professores Alfabetizadores; s) solicitar ao FNDE oficialmente a interrupção ou o cancelamento de pagamento de bolsas, quando for o caso; II - do Fundo Nacional de Desenvolvimento da Educação - FNDE: a) providenciar, por ocasião da primeira solicitação de pagamento de bolsa, a abertura de contabenefício específica, na agência do Banco do Brasil S/A indicada entre as disponíveis no SGB, para cada um dos bolsistas da Formação Continuada de Professores Alfabetizadores cujos cadastros pessoais estejam registrados naquele sistema informatizado; b) efetivar o pagamento mensal das bolsas concedidas pela SEB/MEC, depois de atendidas pelo gestor nacional da Formação Continuada de Professores Alfabetizadores e pelos coordenadores-gerais e adjuntos das IES as obrigações estabelecidas nesta resolução; c) suspender o pagamento das bolsas sempre que ocorrerem situações que justifiquem a medida, inclusive por solicitação da SEB/MEC; d) manter o SGB em operação para possibilitar o cadastramento dos bolsistas e a solicitação de pagamento das bolsas por parte dos coordenadores-gerais ou adjuntos da Formação nas IES, bem como permitir a homologação das informações por parte do gestor nacional; e) monitorar o pagamento de bolsas junto ao Banco do Brasil S/A; f) fornecer relatórios periódicos sobre o pagamento de bolsas à SEB/MEC; g) prestar informações à SEB/MEC, sempre que solicitadas; e h) divulgar informações sobre o pagamento das bolsas no portal eletrônico www.fnde.gov.br; III - das instituições de ensino superior (IES): a) atender às exigências desta resolução; b) realizar a gestão acadêmica e pedagógica do curso de formação; c) selecionar os formadores que ministrarão o curso de formação aos orientadores de estudo; d) assegurar espaço físico e material de apoio adequados para os encontros presenciais da formação dos orientadores de estudo; e) instituir, por portaria do dirigente, o coordenador geral da Formação Continuada de Professores Alfabetizadores na IES, cujas responsabilidades estão descritas no art. 15 desta resolução. f) enviar à SEB/MEC, por intermédio do SisPacto, uma cópia autenticada do Termo de Compromisso (Anexo I) do coordenador geral da Formação Continuada de Professores Alfabetizadores na IES, devidamente assinada por ele e pelo dirigente da Instituição; g) homologar a indicação do coordenador-adjunto, feita pelo coordenador-geral da Formação Continuada de Professores Alfabetizadores, e a seleção dos demais bolsistas vinculados à Instituição; h) coordenar o processo de seleção dos supervisores e formadores da Formação, respeitando estritamente os pré-requisitos estabelecidos para cada 
função quanto à formação e quanto à experiência exigidas, assegurando publicidade e transparência a esse processo e impedindo que 5 este venha a sofrer interferências indevidas, relacionadas a laços de parentesco ou proximidade pessoal; i) homologar e encaminhar à SEB/MEC, por intermédio do SisPacto, cópia devidamente assinada e autenticada do Termo de Compromisso (Anexo I) de cada um dos bolsistas: do coordenador-adjunto, dos supervisores e formadores da IES, bem como dos coordenadores estaduais e municipais, dos orientadores de estudo e dos professores alfabetizadores; j) responsabilizar-se pela inserção completa e correta dos dados cadastrais dos participantes nos cursos, bem como dos dados cadastrais dos professores das redes públicas em processo de formação, tanto no SisPacto como no SGB; k) encaminhar à SEB/MEC, por meio do SisPacto, relatórios de ocorrência relativos à interrupção ou cancelamento do pagamento de bolsas ou substituição de bolsista(s); 1) encaminhar ao FNDE, por meio do SGB, os lotes mensais com as solicitações de pagamento aos bolsistas participantes do Programa, atestados por certificação digital devidamente registrada naquele sistema; m) garantir a atualização mensal, no SisPacto e no SGB, das informações cadastrais de todos bolsistas vinculados à IES; n) certificar os orientadores de estudo e os professores alfabetizadores que tenham concluído a Formação; o) apresentar relatórios parciais e finais sobre a execução da Formação, no modelo e dentro dos prazos estipulados pela SEB/ MEC nos planos de trabalho; p) manter atualizado banco de dados com todas as informações sobre os participantes da Formação, incluindo registro de frequência e avaliações individuais; q) garantir a atualização dos dados cadastrais de todos os bolsistas e comunicar oficialmente à SEB/MEC as alterações cadastrais efetivadas no SGB, bem como substituições ou desistências, com a respectiva justificativa; r) manter arquivada, pelo período de vinte anos, contados a partir da data da aprovação da prestação de contas anual do FNDE pelo Tribunal de Contas da União (TCU), toda a documentação comprobatória e toda informação produzida, pertinentes aos controles da execução da Formação, para verificação periódica pelo MEC, pelo FNDE e por qualquer órgão de controle interno ou externo do Governo Federal que os requisite; IV - das secretarias de Educação dos estados, do Distrito Federal e dos municípios: a) gerenciar e monitorar a implementação da Formação em sua rede; b) designar o coordenador das ações do Pacto no estado, Distrito Federal ou município, obrigatoriamente um servidor público, que será responsável pelo gerenciamento da sua respectiva rede, encaminhando à SEB/MEC, via SisPacto, uma cópia devidamente assinada e autenticada de seu Termo de Compromisso; c) indicar os orientadores de estudo de sua rede, a serem formados pelas IES, e custear o seu deslocamento, alimentação e hospedagem para os eventos da formação, sempre que necessário; d) fomentar e garantir a 
participação dos professores alfabetizadores de sua rede nas atividades da Formação, sem prejuízo da carga horária em sala de aula, custeando seu deslocamento, alimentação hospedagem, sempre que necessário; e) monitorar a aplicação das avaliações diagnósticas e da avaliação externa, a entrega e o uso dos materiais didáticos, literários e dos recursos de apoio à alfabetização, componentes das ações do Pacto; f) disponibilizar assistência técnica às escolas e, no caso dos estados, também aos municípios com maiores dificuldades na implementação do Pacto e na obtenção de resultados positivos de alfabetização. 6 II - DA SELEÇÃO DOS PARTICIPANTES DA FORMAÇÃO

Art. $8^{\circ} \mathrm{O}$ coordenador-geral da Formação Continuada de Professores Alfabetizadores deverá ser indicado pelo dirigente máximo da instituição de ensino superior, que o escolherá prioritariamente dentre aqueles que atendam aos seguintes requisitos cumulativos: I - ser professor efetivo(a) da IES; II - ter experiência na área de formação continuada de profissionais da educação básica; III - possuir titulação de mestrado ou doutorado. Parágrafo único. O coordenador-geral deverá encaminhar ao gestor nacional da Formação Continuada de Professores Alfabetizadores na SEB/MEC, por intermédio do SisPacto, cópias tanto de seu Termo de Compromisso de Bolsista (Anexo I), devidamente assinada e homologada pelo dirigente máximo da IES, como do instrumento comprobatório da sua designação.

Art. $9^{\circ} \mathrm{O}$ coordenador-adjunto será indicado pelo coordenador-geral da Formação na instituição de ensino superior, devendo ser selecionado dentre os que reúnam, no mínimo, aos seguintes requisitos cumulativos: I - ser professor efetivo da IES; II - ter experiência na área de formação de professores alfabetizadores; III - possuir titulação de especialização, mestrado ou doutorado. $\S 1^{\circ} \mathrm{A}$ indicação do coordenador-adjunto deverá ser homologada pelo dirigente máximo da IES, em seu Termo de Compromisso. $§ 2^{\circ}$ As IES responsáveis pela realização da Formação Continuada de Professores Alfabetizadores em mais de uma unidade da federação poderão indicar até um coordenador-adjunto para cada estado.

Art. 10. Os supervisores serão escolhidos em processo de seleção pública e transparente, livre de interferências indevidas, relacionadas seja a laços de parentesco, seja a proximidade pessoal, respeitando-se estritamente os pré-requisitos estabelecidos para a função quanto à formação e à experiência exigidas, dentre candidatos que reúnam, no mínimo, as seguintes características cumulativas: I - ter experiência na área de formação de professores alfabetizadores; II - possuir titulação de especialização, mestrado ou doutorado. Parágrafo único. Caso já seja bolsista de outro programa de formação de professores para a educação básica regido pela Lei no 11.273/2006, o supervisor selecionado, ainda que não possa acumular o recebimento de bolsa em mais do que um deles, poderá assumir esta função, desde 
que não haja qualquer comprometimento ao desempenho de suas responsabilidades e atribuições regulares na Instituição, seja em termos de sua jornada de trabalho seja em termos de dedicação e comprometimento.

Art. 11. Os formadores serão selecionados pelo coordenador-geral da IES, em processo de seleção público e transparente, livre de interferências indevidas, relacionadas seja a laços de parentesco, seja a proximidade pessoal, respeitando-se estritamente os pré-requisitos estabelecidos para a função quanto à formação e à experiência exigidas, sendo que a seleção deverá pautar-se pelos seguintes critérios cumulativos: I - o candidato deve possuir experiência na área de formação de professores alfabetizadores; 7 II - ter atuado como professor alfabetizador ou formador de professores alfabetizadores durante, pelo menos, dois anos; III - ser formado em Pedagogia ou áreas afins, ou ter Licenciatura; IV - possuir titulação de especialização, mestrado ou doutorado ou estar cursando pós-graduação na área de Educação.

Art. 12. O coordenador das ações do Pacto no Distrito Federal, nos estados ou nos municípios será indicado pela respectiva secretaria de Educação e deverá ser selecionado preferencialmente dentre aqueles que atendam às seguintes características cumulativas: I - ser servidor efetivo da secretaria de Educação; II - ter experiência na coordenação de projetos ou programas federais; III - possuir amplo conhecimento da rede de escolas, dos gestores escolares e dos docentes envolvidos no ciclo de alfabetização; IV - ter capacidade de se comunicar com os atores locais envolvidos no ciclo de alfabetização e de mobilizá-los; V - ter familiaridade com os meios de comunicação virtuais. $\S 1^{\circ}$ É vedada a designação de qualquer dirigente da Educação do estado, do Distrito Federal ou do município para atuar como coordenador das ações do Pacto. $\S 2^{\circ} \mathrm{Na}$ hipótese de a Secretaria não conseguir selecionar um profissional com o perfil requerido ou com disponibilidade para assumir a coordenação das ações do Pacto entre os servidores de seu quadro efetivo, poderá excepcionalmente indicar profissional contratado ou com vínculo de trabalho temporário. $\S 3^{\circ}$ Caso o coordenador das ações do Pacto selecionado já seja bolsista de outro programa de formação de professores para a educação básica regido pela Lei no 11.273/2006, não poderá acumular o recebimento de bolsa em mais do que um dos programas, mas poderá assumir a função, desde que não haja qualquer comprometimento ao desempenho de suas responsabilidades e atribuições regulares, seja em termos da jornada de trabalho seja em termos de dedicação e comprometimento. $\S 4^{\circ}$ $\mathrm{O}$ atendimento aos requisitos estabelecidos no caput e nos $\S \S 1^{\circ}, 2^{\circ}$ e $3^{\circ}$ deste artigo bem como aos expressos na Lei no 11.273/2006 é de responsabilidade de cada ente federativo, podendo o MEC, o FNDE ou os órgãos de controle do Governo Federal, a qualquer tempo, 
solicitar esclarecimentos ou documentos comprobatórios do cumprimento de tais requisitos. Art. 13. Os orientadores de estudo serão escolhidos em processo de seleção público e transparente, livre de interferências indevidas, relacionadas seja a laços de parentesco, seja a proximidade pessoal, respeitando-se estritamente os pré-requisitos estabelecidos para a função quanto à formação e à experiência exigidas, sendo selecionados entre os profissionais que atendam aos seguintes requisitos: I - ser professor efetivo da rede pública de ensino que promove a seleção; II - ter sido tutor do Programa Pró-Letramento; III - ter disponibilidade para dedicar-se ao curso e à multiplicação junto aos professores alfabetizadores. $\S 1^{\circ} \mathrm{Na}$ seleção dos orientadores de estudo, caso a rede de ensino não disponha de professores que tenham sido tutores do Pró-Letramento ou por outras razões que deverão ser devidamente justificadas no momento do cadastramento, a secretaria de Educação deverá considerar o currículo, a experiência e a 8 habilidade didática do candidato, sendo que o selecionado deve preencher os seguintes requisitos cumulativos: I - ser profissional do magistério efetivo da rede; II - ser formado em Pedagogia ou ter Licenciatura; III - atuar há, no mínimo, três anos nas séries iniciais do ensino fundamental, como professor ou coordenador pedagógico ou possuir experiência comprovada na formação de professores alfabetizadores. $\S 2^{\circ} \mathrm{O}$ profissional que atua na rede de ensino como coordenador pedagógico só poderá participar da Formação na condição de professor alfabetizador e receber a respectiva bolsa de estudo se atender aos seguintes requisitos cumulativos: I - lecionar em turmas do $1^{\circ}, 2^{\circ}, 3^{\circ}$ ano ou em turmas multisseriadas formadas por alunos desses anos; e II - constar do Censo Escolar disponível no momento da constituição da turma de professores alfabetizadores da Formação da qual participará. $\S 3^{\circ}$ Os requisitos previstos no caput e nos $\S \S 1^{\circ}$ e $2^{\circ}$ deverão ser documentalmente comprovados pelo(a) orientador(a) de estudo no ato da matrícula na IES responsável pela Formação.

Art. 14. O orientador de estudo deverá permanecer como professor do quadro efetivo do magistério da rede pública de ensino que o indicou durante toda a realização da Formação Continuada de Professores Alfabetizadores, sob pena de exclusão do curso e devolução do valor relativo às bolsas recebidas. $\S 1^{\circ} \mathrm{O}$ orientador de estudo somente poderá ser substituído nos seguintes casos: I - deixar de cumprir os requisitos previstos no art. 13 desta resolução; II - por solicitação do próprio orientador de estudo. $\S 2^{\circ}$ Em caso de substituição de orientador de estudo, o coordenador das ações do Pacto no Distrito Federal, estado ou município deverá encaminhar documento que a justifique à IES formadora. $\S 3^{\circ}$ Em caso de substituição do orientador de estudo, a IES formadora realizará a formação necessária para o seu substituto, visando compensar a ausência nos encontros formativos anteriores. III - DAS 


\section{ATRIBUIÇÕES DOS PARTICIPANTES DA FORMAÇÃO CONTINUADA DE PROFESSORES ALFABETIZADORES}

Art. 15. São atribuições dos participantes da Formação Continuada de Professores Alfabetizadores: I - do coordenador-geral da IES: a) articular e monitorar o conjunto das atividades necessárias ao desenvolvimento da Formação; b) encaminhar ao gestor nacional da Formação, na SEB/MEC, por intermédio do SisPacto, cópia de seu Termo de Compromisso (Anexo I) e da portaria ou outro ato administrativo que o designou para exercer a função, bem como os dados relativos à sua certificação digital, para que estes sejam registrados nos sistemas informatizados do MEC e do FNDE; c) coordenar ações pedagógicas, administrativas e financeiras, responsabilizando-se pela tomada de decisões de caráter administrativo e logístico, incluindo a gerência dos materiais e a garantia da infraestrutura necessária para o desenvolvimento da formação; d) escolher o coordenador-adjunto da Formação, que deverá ser homologado pelo dirigente máximo 9 da Instituição; e) coordenar o processo de seleção dos supervisores e formadores da Formação Continuada de Professores Alfabetizadores na respectiva Instituição, homologando os selecionados no SisPacto; f) organizar a equipe técnico-pedagógica que será responsável pela implementação da Formação, supervisionando suas atividades; g) coordenar a elaboração dos projetos e planos de trabalho e acompanhar a tramitação dos documentos; h) coordenar a gestão do curso e zelar pelo cumprimento das metas pactuadas com o MEC e com os sistemas públicos de ensino; i) homologar a concessão de bolsas ao coordenador-adjunto, aos supervisores, aos formadores, aos coordenadores das ações do Pacto nos estados, Distrito Federal e municípios, aos orientadores de estudo e aos professores alfabetizadores sob sua responsabilidade; j) assinar os Termos de Compromisso (Anexo I) de todos os bolsistas, previamente preenchidos e assinados por eles, para que sejam incluídos no SisPacto; k) assegurar fidedignidade e correção ao cadastramento de seus dados pessoais bem como aos dados dos demais bolsistas vinculados à IES e registrados no SisPacto e no Sistema de Gestão de Bolsas (SGB), 1) garantir a permanente atualização dos dados cadastrais de todos os bolsistas nos sistemas do MEC e do FNDE, comunicando oficialmente à SEB/MEC alterações cadastrais efetivadas, substituições ou desistências, com a respectiva justificativa; m) solicitar mensalmente, por intermédio do SGB e com certificação digital própria, os pagamentos a todos os bolsistas que fizerem jus à bolsa no período de referência, responsabilizando-se pela veracidade e fidedignidade das solicitações; $n$ ) manter banco de dados atualizado com todas as informações sobre os participantes da Formação, incluindo registro de frequência e avaliações individuais; o) garantir, juntamente com o coordenador-adjunto, a imediata substituição de formadores e 
orientadores de estudo que sofram qualquer impedimento no decorrer da formação, registrando-as no SGB; p) elaborar e encaminhar relatórios parciais e final das atividades da Formação por intermédio do SisPacto; q) participar ou fazer-se representar nas reuniões técnicas da Formação; r) coordenar o processo de certificação dos orientadores de estudo e dos professores alfabetizadores; s) responsabilizar-se pela organização da prestação de contas dos recursos recebidos para financiar a Formação, conforme a legislação vigente; t) incumbirse, na condição de pesquisador, de desenvolver, adequar e sugerir modificações na metodologia de ensino adotada, bem como conduzir análises e estudos sobre o desempenho do curso; II - do coordenador-adjunto da IES: a) coordenar a implementação da formação e as ações de suporte tecnológico e logístico; b) organizar, em articulação com as secretarias de Educação e os coordenadores das ações do Pacto nos estados, Distrito Federal e municípios, os encontros presenciais, as atividades pedagógicas, o calendário acadêmico e administrativo, dentre outras atividades necessárias à realização da Formação; c) exercer a coordenação acadêmica da formação; 10 d) homologar os cadastros dos orientadores de estudo e dos professores alfabetizadores nos sistemas disponibilizados pelo MEC; e) indicar ao coordenador-geral da IES a manutenção ou o desligamento de bolsistas; f) assegurar, juntamente com o coordenador-geral da IES, a imediata substituição de formadores que sofram qualquer impedimento no decorrer do curso, registrando-as nos sistemas disponibilizados pelo MEC; g) recomendar a manutenção ou o desligamento dos coordenadores das ações do Pacto nos estados, Distrito Federal e municípios, dos orientadores de estudo e dos professores alfabetizadores, em articulação com as respectivas Secretarias de Educação, comunicando-as ao coordenador-geral da IES; h) solicitar, durante a duração do curso, os pagamentos mensais aos bolsistas que tenham feito jus ao recebimento de sua respectiva bolsa, por intermédio do SGB; i) organizar o seminário final do estado, juntamente com o coordenador-geral da IES; j) incumbir-se, na condição de pesquisador, de desenvolver, adequar e sugerir modificações na metodologia de ensino adotada, bem como conduzir análises e estudos sobre a implementação da formação, divulgando seus resultados; e k) substituir o coordenador-geral nos impedimentos deste; III - do supervisor: a) apoiar o coordenador-adjunto da IES na coordenação acadêmica da Formação, realizando o acompanhamento das atividades didático-pedagógica dos formadores; b) coordenar e acompanhar as atividades pedagógicas de capacitação e supervisão dos orientadores de estudo; c) assegurar-se de que todos os orientadores de estudo selecionados bem como os professores alfabetizadores tenham assinado o Termo de Compromisso do Bolsista (Anexo I); d) averiguar mensalmente o preenchimento integral dos dados cadastrais dos orientadores de 
estudo e dos professores alfabetizadores, para que possam receber as bolsas a que fizerem jus; e) acompanhar a formação, propiciando condições que favoreçam um ambiente de aprendizagem, bem como mecanismos que assegurem o cumprimento do cronograma de implementação; f) acompanhar o andamento da formação e relatar ao coordenador-adjunto e ao coordenador-geral da IES os problemas enfrentados pelos cursistas; g) reunir-se sistematicamente com os coordenadores das ações do Pacto dos estados, Distrito Federal e municípios, visando a monitorar a assiduidade dos orientadores de estudo e dos professores alfabetizadores nos encontros presenciais; IV - do formador da IES: a) planejar e avaliar as atividades da Formação; b) ministrar a Formação aos orientadores de estudo; c) validar, junto ao coordenador-adjunto, os cadastros dos orientadores de estudo e dos professores alfabetizadores nos sistemas do MEC e do FNDE; d) monitorar a frequência, a participação e as avaliações dos orientadores de estudo no SisPacto; e) acompanhar as atividades dos orientadores de estudo junto aos professores alfabetizadores; f) organizar os seminários ou encontros com os orientadores de estudo para acompanhamento e avaliação da Formação; g) analisar e discutir os relatórios de formação com os orientadores de estudo; h) elaborar e encaminhar ao supervisor da Formação os relatórios dos encontros presenciais; 11 i) analisar, em conjunto com os orientadores de estudo, os relatórios das turmas de professores alfabetizadores e orientar os encaminhamentos; j) encaminhar a documentação necessária para a certificação dos orientadores de estudo e dos professores alfabetizadores; e k) acompanhar, no SisPacto, o desempenho das atividades de formação previstas para os orientadores de estudo sob sua responsabilidade, informando ao supervisor sobre eventuais ocorrências que interfiram no pagamento da bolsa no período. V - do coordenador das ações do Pacto nos estados, Distrito Federal e municípios: a) dedicar-se às Ações do Pacto e atuar na Formação na qualidade de gestor das ações; b) cadastrar os orientadores de estudo e os professores alfabetizadores no SisPacto e no SGB; c) monitorar a realização dos encontros presenciais ministrados pelos orientadores de estudo junto aos professores alfabetizadores; d) apoiar as IES na organização do calendário acadêmico, na definição dos polos de formação e na adequação das instalações físicas para a realização dos encontros presenciais; e) assegurar, junto à respectiva secretaria de Educação, as condições de deslocamento e hospedagem para participação nos encontros presenciais dos orientadores de estudo e dos professores alfabetizadores, sempre que necessário; f) articular-se com os gestores escolares e coordenadores pedagógicos visando ao fortalecimento da Formação Continuada de Professores Alfabetizadores; g) organizar e coordenar o seminário de socialização de experiências em seu âmbito de atuação (municipal, estadual ou distrital); h) monitorar o 
recebimento e devida utilização dos materiais pedagógicos previstos nas ações do Pacto; i) acompanhar as ações da secretaria de Educação na aplicação das avaliações diagnósticas, e assegurar que os professores alfabetizadores registrem os resultados obtidos pelos alunos no SisPacto; j) acompanhar as ações da Secretaria de Educação na aplicação das avaliações externas, assegurando as condições logísticas necessárias; k) manter canal de comunicação permanente com o Conselho Estadual ou Municipal de Educação e com os Conselhos Escolares, visando a disseminar as ações do Pacto, prestar os esclarecimentos necessários e encaminhar eventuais demandas junto à secretaria de Educação e à SEB/MEC; e 1) reunir-se constantemente com o titular da secretaria de Educação para avaliar a implementação das ações do Pacto e implantar as medidas corretivas eventualmente necessárias; VI - do orientador de estudo: a) participar dos encontros presenciais junto às IES, alcançando no mínimo $75 \%$ de presença; b) assegurar que todos os professores alfabetizadores sob sua responsabilidade assinem o Termo de Compromisso do Bolsista (Anexo I), encaminhando-os ao coordenador-geral da Formação na IES; c) ministrar a formação aos professores alfabetizadores em seu município ou polo de formação; d) planejar e avaliar os encontros de formação junto aos professores alfabetizadores; e) acompanhar a prática pedagógica dos professores alfabetizadores; f) avaliar os professores alfabetizadores cursistas quanto à frequência, à participação e ao acompanhamento dos estudantes, registrando as informações no SisPacto; g) efetuar e manter atualizados os dados cadastrais dos professores alfabetizadores; h) analisar os relatórios das turmas de professores alfabetizadores e orientar os encaminhamentos; i) manter registro de atividades dos professores alfabetizadores em suas turmas de alfabetização; 12 j) avaliar, no SisPacto, a atuação dos formadores, dos coordenadores das ações do Pacto no Distrito Federal, nos estados e nos municípios e do suporte dado pelas IES; e k) apresentar à IES formadora os relatórios pedagógico e gerencial das atividades referentes à formação dos professores alfabetizadores; VII - do professor alfabetizador: a) dedicar-se ao objetivo de alfabetizar todas as crianças de sua(s) turma(s) no ciclo de alfabetização; b) analisar os textos propostos nos encontros da Formação, registrando as questões a serem discutidas nos encontros posteriores; c) participar dos encontros presenciais com os orientadores de estudo, alcançando no mínimo $75 \%$ de presença; d) realizar em sala de aula as atividades planejadas nos encontros da Formação, registrando as dificuldades para debate nos encontros posteriores; e) colaborar com as discussões pedagógicas relacionadas aos materiais e à formação; f) planejar situações didáticas utilizando os recursos didáticos disponibilizados pelo Ministério da Educação; g) aplicar as avaliações diagnósticas registrando os resultados no SisPacto ou utilizando outra forma pactuada 
previamente com seu respectivo orientador de estudo; h) acompanhar o progresso da aprendizagem das suas turmas de alfabetização, registrando-o no SisPacto ou outras formas de registro pactuadas com o respectivo orientador de estudo; i) avaliar o trabalho de formação desenvolvido pelo orientador de estudo; e j) participar do seminário final da Formação Continuada de Professores Alfabetizadores e apresentar relato de sua experiência.

\section{IV - DA CONSTITUIÇÃO DE TURMAS DE PROFESSORES ALFABETIZADORES}

Art. 16. A constituição das turmas de professores alfabetizadores obedecerá ao disposto abaixo: I - cada turma deverá ter 25 (vinte e cinco) professores alfabetizadores que atuam em um mesmo ano ou que atuam em turmas multisseriadas e multietapas, podendo chegar a 34 (trinta e quatro) docentes, dependendo do total de professores alfabetizadores da rede; II cada turma de professores alfabetizadores deverá ter um orientador de estudo, responsável por formar os cursistas. $\S 1^{\circ}$ Os dados do Censo Escolar do INEP disponível à época da montagem das turmas será a referência utilizada para cálculo da quantidade máxima de professores alfabetizadores e orientadores de estudo que deverão/poderão participar da Formação. $\S 2^{\circ}$ No caso de, somando-se todos os anos e turmas, não haver um número suficiente para compor uma turma, poderão ser formadas turmas mistas com, no mínimo, 10 (dez) professores. $\S 3^{\circ} \mathrm{Na}$ hipótese do parágrafo anterior, recomenda-se que os encontros presenciais sejam feitos em momentos distintos, visando conferir maior efetividade à formação. $\S 4^{\circ}$ No caso de haver menos que 10 (dez) professores alfabetizadores no município ou localidade, será facultada a indicação de 1 (um) orientador de estudo ou a solicitação de inclusão desses professores às turmas da rede estadual, condicionada à aceitação da Secretaria Estadual demandada. $13 \S 5^{\circ}$ Caberá à IES responsável pela formação no município avaliar e deliberar pela fusão de turmas em caso de evasão ou abandono, observados os parágrafos anteriores.

\section{V - DO PAGAMENTO DE BOLSAS}

Art. 17. A título de bolsa, o FNDE pagará aos participantes, mensalmente e durante a duração do curso da Formação Continuada de Professores Alfabetizadores, os seguintes valores: I - ao coordenador-geral da IES: R \$ 1.500,00 (mil e quinhentos reais); II - ao coordenador-adjunto da IES: R\$ 1.400,00 (mil e quatrocentos reais); III - ao supervisor da IES: R \$ 1.200,00 (mil e duzentos reais); IV - ao formador da IES: R $\$ 1.100,00$ (mil e cem reais); V - ao coordenador das ações do Pacto nos estados, Distrito Federal e municípios: R\$ 765,00 (setecentos e sessenta e cinco reais); VI - ao orientador de estudo: $\mathrm{R} \$ 765,00$ (setecentos e sessenta e cinco reais); e VII - ao professor alfabetizador: $\mathrm{R} \$ 200,00$ (duzentos reais). 
Art. 18. A bolsa será concedida pela SEB/MEC e paga pelo FNDE diretamente aos beneficiários, por meio de crédito em conta-benefício específica, mediante aceitação, pelo bolsista, de Termo de Compromisso (Anexo I) em que constem, dentre outros: I - autorização para o FNDE, conforme o caso, bloquear valores creditados na conta-benefício, mediante solicitação direta ao Banco do Brasil S/A, ou proceder ao desconto nos pagamentos subseqüientes, nas seguintes situações: a) ocorrência de depósitos indevidos; b) determinação do Poder Judiciário ou requisição do Ministério Público; e c) constatação de irregularidades na comprovação da freqüência do bolsista; d) constatação de incorreções nas informações cadastrais do bolsista. II - obrigação do bolsista de, inexistindo saldo suficiente na contabenefício e não havendo pagamentos futuros a serem efetuados, restituir ao FNDE, no prazo de 15 (quinze) dias a contar da data do recebimento da notificação, os valores creditados indevidamente ou objeto de irregularidade constatada, na forma prevista no art. 25 desta resolução. Parágrafo único. A bolsa será paga durante todo o período efetivo de realização da Formação, podendo ser paga por tempo inferior ou mesmo sofrer interrupção, desde que justificada.

Art. 19. A título de bolsa, de acordo com a responsabilidade assumida por cada beneficiário e com o efetivo cumprimento de suas atribuições, o FNDE pagará mensalmente, durante o período da Formação, o valor estipulado no art. 17, por meio de depósito em conta-benefício específica para esse fim, aberta pelo FNDE em agência do Banco do Brasil S/A, indicada pelo bolsista entre aquelas cadastradas no SGB. $\S 1^{\circ}$ Os bolsistas somente farão jus ao recebimento de uma bolsa por período, mesmo que venham a exercer mais de uma função. $\S 2^{\circ} \mathrm{O}$ recebimento de qualquer um dos tipos de bolsa de que trata este artigo vinculará o participante à Formação Continuada de Professores Alfabetizadores. $14 \S 3^{\circ}$ A renovação das bolsas somente poderá ocorrer findo o prazo de duração da Formação Continuada de Professores Alfabetizadores e desde que o bolsista seja submetido a novo procedimento de seleção. $\S 4^{\circ}$ É vedado ao participante da Formação Continuada de Professores Alfabetizadores o recebimento de mais de uma bolsa de estudo, pesquisa e desenvolvimento de metodologias educacionais, cujo pagamento tenha por base a Lei no 11.273/2006.

Art. 20. As despesas com a execução das ações previstas nesta resolução correrão por conta de dotação orçamentária consignada anualmente ao FNDE, observando limites de movimentação, empenho e pagamento da programação orçamentária e financeira anual.

Art. 21. Para que as bolsas sejam pagas, os lotes abertos mensalmente no SGB pela SEB/MEC pelo gestor nacional da Formação Continuada de Professores Alfabetizadores, contendo a relação de bolsistas aptos, devem ser analisados pelo coordenador-geral da IES, 
que solicitará os pagamentos devidos àqueles que fizerem jus ao recebimento no período de referência, usando sua certificação digital individual, previamente registrada junto aos sistemas do MEC e do FNDE. Parágrafo único. As ocorrências mensais relatadas pelas IES farão parte do processo de liberação do pagamento mensal. O gestor nacional homologará as solicitações feitas pelos gestores locais no SGB após o recebimento do relatório de ocorrências. Só então, o lote mensal com a solicitação de pagamento aos bolsistas de cada programa será encaminhado ao FNDE, para as providências relativas aos créditos de bolsas nas contas-benefício dos beneficiários.

Art. 22. As contas-benefício de que trata o art. 18 ficarão bloqueadas até que o bolsista compareça à agência onde a conta foi aberta e proceda à entrega e à chancela dos documentos necessários à movimentação dos créditos, de acordo com as normas bancárias vigentes, e, ainda, efetue o cadastramento de sua senha pessoal e retire o cartão magnético destinado ao saque dos valores depositados a título de bolsa de estudo e pesquisa.

Art. 23. As contas-benefício depositárias dos valores das bolsas são isentas do pagamento de tarifas bancárias sobre sua manutenção e movimentação, conforme previsto no Acordo de Cooperação Mútua firmado entre o FNDE/MEC e o Banco do Brasil S/A. Parágrafo único. A isenção de tarifas abrange o fornecimento de um único cartão magnético, a realização de saques e a consulta a saldos e extratos da conta-benefício.

Art. 24. Os saques e a consulta a saldos e extratos deverão ocorrer exclusivamente por meio de cartão magnético, nos terminais de auto-atendimento do Banco do Brasil S/A ou de seus correspondentes bancários, mediante a utilização de senha pessoal e intransferível. Parágrafo único. O Banco não fornecerá talonário de cheques aos bolsistas, podendo ainda restringir o número de saques, de depósitos e de consultas a saldos e extratos.

Art. 25. Excepcionalmente, quando os múltiplos de valores estabelecidos para saques nos terminais de auto-atendimento forem incompatíveis com os valores dos saques a serem efetuados pelos bolsistas o banco acatará saques e consultas nos caixas convencionais mantidos em suas agências bancárias.

Art. 26. O bolsista que efetuar movimentação de sua conta-benefício em desacordo com o estabelecido nesta resolução ou solicitar a emissão de segunda via do cartão magnético ficará sujeito ao pagamento das correspondentes tarifas bancárias.

Art. 27. Os créditos não sacados pelos bolsistas no prazo de dois anos após a data do respectivo depósito serão revertidos pelo Banco em favor do FNDE, que não se obrigará a novo pagamento sem que haja solicitação formal do beneficiário, acompanhada da 
competente justificativa e da anuência dos gestores local e nacional da Formação Continuada de Professores Alfabetizadores.

Art. 28. Ao FNDE, observadas as condições estabelecidas no inciso I do art. 18 desta resolução, é facultado bloquear valores creditados na conta-benefício do bolsista, mediante solicitação direta ao Banco do Brasil S/A, ou proceder aos descontos nos pagamentos futuros. Art. 29. Inexistindo saldo suficiente na conta-benefício do bolsista e não havendo previsão de pagamento a ser efetuado, o bolsista ficará obrigado a restituir os recursos ao FNDE, no prazo de 15 (quinze) dias a contar da data do recebimento da notificação, na forma prevista no art. 33.

Art. 30. Sendo identificadas incorreções nos dados cadastrais da conta-benefício é facultado ao FNDE adotar providências junto ao Banco do Brasil S/A, visando à regularização da situação, independentemente de autorização do bolsista.

Art. 31. As responsabilidades dos bolsistas da Formação Continuada de Professores Alfabetizadores constam do art. 15 desta resolução e devem ser reiteradas no preenchimento e na assinatura do Anexo I (Termo de compromisso do bolsista). Parágrafo único. O descumprimento de qualquer das responsabilidades por parte do bolsista implicará na imediata suspensão dos pagamentos de bolsas a ele destinados, temporária ou definitivamente, dependendo do caso.

Art. 32. O FNDE fica autorizado a suspender ou cancelar o pagamento da bolsa quando: I houver a substituição do bolsista ou o cancelamento de sua participação na Formação Continuada de Professores Alfabetizadores; II - forem verificadas irregularidades no exercício das responsabilidades do bolsista; III - forem constatadas incorreções nas informações cadastrais do bolsista; e IV - for constatada frequência inferior à estabelecida pela Formação Continuada de Professores Alfabetizadores ou acúmulo indevido de benefícios. Parágrafo único. O FNDE fica também autorizado a suspender ou cancelar o pagamento das bolsas ao beneficiário que, a qualquer tempo, não cumprir com os critérios estabelecidos para a Formação Continuada de Professores Alfabetizadores, de acordo com art. 18 desta resolução. Art. 33. As devoluções de valores decorrentes de pagamento efetuado pelo FNDE a título de bolsas de estudo e pesquisa no âmbito da Formação Continuada de Professores Alfabetizadores, independentemente do fato gerador que lhes deram origem, deverão ser efetuadas em agência do Banco do Brasil S/A, mediante utilização da Guia de Recolhimento da União (GRU), disponível no sítio eletrônico www.fnde.gov.br, na qual deverão ser indicados o nome e o CPF do bolsista e ainda: 16 I - se a devolução ocorrer no mesmo ano do pagamento das bolsas e este não for decorrente de Restos a Pagar inscritos pelo FNDE, 
deverão ser utilizados os códigos 153173 no campo "Unidade Gestora", 15253 no campo "Gestão", 66666-1 no campo "Código de Recolhimento" e o código 212198009 no campo "Número de Referência" e, ainda, mês e ano a que se refere à bolsa a ser devolvida no campo "Competência"; II - se a devolução for decorrente de Restos a Pagar inscritos pelo FNDE ou de pagamentos de bolsas ocorridos em anos anteriores ao da emissão da GRU, deverão ser utilizados os códigos 153173 no campo "Unidade Gestora", 15253 no campo "Gestão", 28850-0 no campo "Código de Recolhimento" e o código 212198009 no campo "Número de Referência" e, ainda, mês e ano a que se refere à bolsa a ser devolvida no campo "Competência". Parágrafo único. Para fins do disposto nos incisos I e II deste artigo considera-se ano de pagamento aquele em que o respectivo crédito foi depositado na contabenefício do bolsista, disponível no portal eletrônico www.fnde.gov.br.

Art. 34. Incorreções na abertura das contas-benefício ou nos pagamentos das bolsas causadas por informações falseadas, prestadas pelos bolsistas quando de seu cadastro ou pelo gestor no ateste da frequência às atividades previstas, implicarão no imediato desligamento do responsável pela falsidade e no impedimento de sua participação em qualquer outro programa de bolsas executado pelo FNDE, no prazo de cinco anos, independentemente de sua responsabilização civil e penal.

Art. 35. Os documentos referentes aos critérios de seleção e de execução da Formação Continuada de Professores Alfabetizadores, a relação dos beneficiários e os respectivos valores das bolsas de estudo e pesquisa deverão ser arquivados nas IES, durante o período de vinte anos, contados a partir da data da aprovação da prestação de contas anual do FNDE pelo Tribunal de Contas da União (TCU), e serão de acesso público permanente, ficando à disposição dos órgãos e entidades incumbidos da fiscalização e controle da administração pública.

VI - DA FISCALIZAÇÃO

Art. 36. A fiscalização do cumprimento das condições instituídas nesta resolução por parte das IES, relativas às obrigações dos beneficiários para que façam jus às bolsas da Formação Continuada de Professores Alfabetizadores, é de competência da SEB/MEC, bem como do FNDE e de qualquer órgão do sistema de controle interno ou externo da União, mediante a realização de auditorias, de inspeção e de análise da documentação referente à participação dos beneficiários.

\section{VII - DISPOSIÇÕES FINAIS}

Art. 37. Qualquer pessoa, física ou jurídica, poderá denunciar irregularidades identificadas no pagamento de bolsas no âmbito da Formação Continuada de Professores Alfabetizadores, por 
meio de expediente formal contendo necessariamente: I - exposição sumária do ato ou fato censurável que possibilite sua perfeita determinação; e II - identificação do responsável pela prática da irregularidade, bem como a data do ocorrido. $\S 1^{\circ}$ Quando a denúncia for apresentada por pessoa física, deverão ser fornecidos o nome legível e endereço para resposta ou esclarecimento de dúvidas. $17 \S 2^{\circ}$ Quando o denunciante for pessoa jurídica (partido político, associação civil, entidade sindical etc.), deverá encaminhar cópia de documento que ateste sua constituição jurídica e fornecer, além dos elementos referidos no $\S 1^{\circ}$ deste artigo, o endereço da sede da representante.

Art. 38. As denúncias encaminhadas ao FNDE deverão ser dirigidas à Ouvidoria, no seguinte endereço: I - se por via postal, endereçar para: Ouvidoria FNDE - Setor Bancário Sul Quadra 02 - Bloco F - Edifício FNDE - Brasília - DF, CEP: 70.070-929; II - se por meio eletrônico, enviar mensagem para ouvidoria@fnde.gov.br.

Art. 39. Fica aprovado o formulário que constitui o Anexo I desta resolução, disponível no sítio do FNDE: www.fnde.gov.br.

Art. 40. Casos não previstos nesta resolução serão dirimidos pelo Ministério da Educação, no âmbito do Comitê Gestor do Pacto Nacional pela Alfabetização na Idade Certa.

Art. 41. Esta resolução entra em vigor na data de sua publicação no Diário Oficial da União. JOSE HENRIQUE PAIM FERNANDES 


\section{RESOLUÇÃO N 12, DE 8 DE MAIO DE 2013}

Altera dispositivos da Resolução CD/FNDE nº 4, de 27 de fevereiro de 2013, que estabelece orientações e diretrizes para o pagamento de bolsas de estudo e pesquisa para a Formação Continuada de Professores Alfabetizadores, no âmbito do Pacto Nacional pela Alfabetização na Idade Certa.

\section{O PRESIDENTE DO CONSELHO DELIBERATIVO DO FUNDO NACIONAL DE} DESENVOLVIMENTO DA EDUCAÇÃO (FNDE), no uso das atribuições que lhe são conferidas pelo art. $7^{\circ}, \S 1^{\circ}$, da Lei $n^{\circ} 5.537$, de 21 de novembro de 1968 , e pelos arts $4^{\circ}, \S 2^{\circ}$, e 14 do Anexo I do Decreto $\mathrm{n}^{\circ}$ 7.691, de 2 de março de 2012, publicado no D.O.U. de 6 de março de 2012, e pelos arts. $3^{\circ}$, inciso I, alíneas "a" e "b"; $5^{\circ}$, caput; e 6º inciso VI, do Anexo da Resolução no 31, de 30 de setembro de 2003, publicada no D.O.U. de 2 de outubro de 2003, neste ato representado conforme deliberado na Reunião Extraordinária do Conselho Deliberativo do FNDE, realizada no dia 31 de maio de 2012, e CONSIDERANDO a necessidade e a conveniência de alterar alguns dos procedimentos relativos ao pagamento de bolsas no âmbito do Pacto Nacional pela Alfabetização na Idade Certa, resolve, ad referendum,

Art. $1^{\circ}$ - Alterar o $\operatorname{artigo} 4^{\circ}, \S 1^{\circ}$; o artigo $7^{\circ}$, IV , b; oartigo $12, \S 5^{\circ}$; o artigo 13 , I e II, $\S \S 1^{\circ}$ e $2^{\circ}$; e o artigo 17, I da Resolução/CD/FNDE/n 4, de 27 de fevereiro de 2013, que passarão a vigorar com a seguinte redação:

Art. $4^{\circ}$

$\S 1^{\circ}$ Os recursos para a realização da Formação Continuada de Professores Alfabetizadores serão alocados diretamente no orçamento das instituições de ensino superior (IES) ou transferidos por meio de descentralizações, convênios ou outra formas, com a finalidade de prestar apoio financeiro à execução das ações do Plano de Ações Articuladas (PAR), tendo sua forma de execução regulamentada por resolução específica."

Art. $7^{\circ}$

IV - das secretarias de Educação dos estados, do Distrito Federal e dos municípios:

b) designar o coordenador ou os coordenadores das ações do Pacto no estado, Distrito Federal ou município, obrigatoriamente servidor(es) público(s), que será(ao) responsável(is) pelo 
gerenciamento de sua respectiva rede, encaminhando à SEB/MEC, via SisPacto, uma cópia devidamente assinada e autenticada de seu Termo de Compromisso."

Art. 12.

$\S 5^{\circ}$ As redes de ensino poderão designar um coordenador local das ações do Pacto a cada cem orientadores de estudo registrados no SisPacto."

Art. 13.

$\S 1^{\circ} \mathrm{O}$ professor regente em efetivo exercício $\mathrm{n}^{\circ} 1^{\circ}, 2^{\circ}$ ou $3^{\circ}$ ano ou em turmas multisseriadas ou multietapa, formadas por alunos desses anos que não estiverem computados no Censo Escolar de 2012, poderá participar da turma de orientadores de estudos, porém sem direito a receber bolsa de estudo ou pesquisa.

$\S 2^{\circ} \mathrm{O}$ profissional que atua na rede de ensino como coordenador pedagógico poderá participar da Formação na condição de professor orientador de estudos, cumpridos os critérios estabelecidos no parágrafo $1^{\circ}$ deste artigo."

Art. 17.

I - ao coordenador-geral da IES: R \$2.000,00 (dois mil reais);"

Art. $2^{\circ}$ Alterar o Anexo I da Resolução CD/FNDE nº 4/2013 para o seguinte formulário:

TERMO DE COMPROMISSO DO BOLSISTA

1. PROGRAMA DE FORMAÇÃO CONTINUADA DE PROFESSORES DA EDUCAÇÃO BÁSICA

1.1. DENOMINAÇÃO

Pacto Nacional pela Alfabetização na Idade Certa

2. SECRETARIA DO MEC RESPONSÁ VEL PELA GESTÃO DO PROGRAMA

2.1. DENOMINAÇÃO

Secretaria de Educação Básica do Ministério da 2.2 . SIGLA Educação SEB/MEC 


\section{IDENTIFICAÇÃO DO BOLSISTA}

4.1. NOME COMPLETO (EXATAMENTE COMO CONSTA NO CPF) 4.2. DATA DE 4.3. NOME DA MÃE

\begin{tabular}{|l|l|l|}
\hline \multicolumn{2}{|l|}{ 4.4. DOCUMENTO DE IDENTIDADE (TIPO DE NÚMERO) } & $\begin{array}{l}\text { 4.5. ÓRGÃO } \\
\text { EXPEDIDOR/UF }\end{array}$ \\
\hline 4.6. CPF & 4.7. ESTADO CIVIL & 4.8. PROFISSÃO \\
\hline 4.9. NATURALIDADE & 4.10. NACIONALIDADE \\
\hline 4.11. ENDEREÇO ( ) Residêncial & ( ) Comercial \\
\hline 4.11.1. Logradouro & 4.11.2. Número & 4.11.3. Complemento \\
\hline 4.11.4. Bairro & 4.11.5. Cidade/UF & 4.11.6. CEP \\
\hline
\end{tabular}

4.12. TELEFONES

\begin{tabular}{|l|l|l|}
\hline 4.12.1. Residêncial & 4.12.2. Comercial & 4.12.3. Celular \\
\hline
\end{tabular}
4.13. E-MAIL

\section{INSTITUIÇÃO À QUAL O BOLSISTA ESTÁ VINCULADO}

\begin{tabular}{|l|l|l|}
\hline 5.1. RAZÃO SOCIAL & 5.2. SIGLA & 5.3. CNPJ \\
\hline
\end{tabular}

\subsection{ENDEREÇO (LOGRADOURO, $\mathrm{N}^{\circ}$, COMPLETO, CIDADE, UF E CEP)}

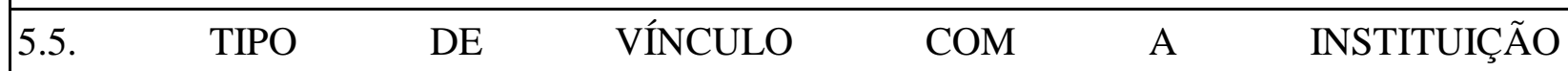

( ) servidor estatutário ( ) contratado temporário ( ) outro - Qual?

5.6. CARGO / FUNÇÃO EXERCIDA

6. ENTIDADE RESPONSÁVEL PELO CADASTRO DE BOLSISTAS NO SISTEMA DE GESTÃO DE BOLSAS (SGB)

\begin{tabular}{|l|l|l|}
\hline 6.1. RAZÃO SOCIAL & 6.2. SIGLA & 6.3. CNPJ \\
\hline 6.4. ENDEREÇO (LOGRADOURO, No , COMPLEMENTO, BAIRRO, CIDADE, UF E CEP) \\
\hline 6.5 REPRESENTANTE LEGAL \\
\hline 6.5.1. NOME & 6.5.2. CARGO \\
\hline 6.6. E-MAIL
\end{tabular}




\begin{tabular}{|l|l|l|}
\hline $\begin{array}{l}\text { 6.7. TELEFONE } \\
\text { RESIDÊNCIAL: }\end{array}$ & $\begin{array}{l}\text { 6.8. TELEFONE } \\
\text { COMERCIAL }\end{array}$ & 6.9. CELULAR \\
\hline 7. COORDENADOR-GERAL DA FORMAÇÃO DE PROFESSORES ALFABETIZADORES \\
\hline 7.1. NOME & 7.3. CARGO \\
\hline 7.2. CPF & \multicolumn{2}{|l|}{} \\
\hline 7.4. E-MAIL INSTITUCIONAL \\
\hline $\begin{array}{l}\text { 7.5. TELEFONE } \\
\text { RESIDÊNCIAL }\end{array}$ & 7.6. TELEFONE & 7.7. CELULAR \\
\hline
\end{tabular}

Declaro ter ciência dos direitos e das obrigações inerentes à qualidade de participante da Formação de Professores Alfabetizadores do Pacto Nacional Pela Alfabetização Na Idade Certa, na função de e

COMPROMETO-ME a desempenhar as atribuições relativas a essa função, definidas nA Resolução CD/FNDE nº 4/2013. Declaro, sob as penas da lei, que as informações aqui prestadas são a expressão da verdade, que tenho anos de experiência no ensino

Declaro também que o desempenho da função indicada acima não comprometerá o desempenho de minhas responsabilidades e atribuições regulares na Instituição/Entidade , à qual estou vinculado, seja em termos de horas seja em termos de dedicação e comprometimento com o trabalho.

Declaro, ainda, que preencho plenamente os requisitos para o recebimento da bolsa, expressos na Lei $n^{\circ} 11.273$ de 6 de fevereiro de 2006 e na Resolução CF/FNDE no 4/2013, e que o recebimento da bolsa no âmbito da Formação Continuada de Professores Alfabetizadores não constituirá acúmulo de bolsa de estudo ou pesquisa proveniente de outros programas regidos pela referida Lei $\mathrm{n}^{\mathrm{o}}$ 11.273/2006.

Autorizo o Fundo Nacional de Desenvolvimento da Educação a, caso ocorram eventuais créditos indevidos em meu favor, bloquear tais valores junto ao Banco do Brasil S/A ou, não havendo saldo suficiente, descontá-los em pagamentos subsequentes. Se não houver 
pagamentos futuros de bolsas, comprometo-me a restituir tais recursos na forma do art. 33 da Resolução CD/FNDE nº 4/2013.

Estou ciente que a inobservância dos requisitos citados acima implicará no cancelamento da(s) bolsa(s), com a restituição integral e imediata dos recursos, de acordo com as regras previstas na Resolução CD/FNDE n $4 / 2013$, da qual este Termo de Compromisso constitui o Anexo I.

LOCAL E DATA

\section{ASSINATURA DO BOLSISTA}

Art. $3^{\circ}$ Esta resolução entra em vigor na data de sua publicação no Diário Oficial da União. JOSÉ HENRIQUE PAIM FERNANDES 